\title{
Results of the complex analyses of the Gyürüfü Rhyolite Formation in the Tisza Mega-unit (Hungary)
}

A Gyürüfüi Riolit Formáció komplex vizsgálati eredményei a Tiszaiföegységben

$\mathrm{PhD}$ Thesis

Author

Máté András Szemerédi

\author{
Supervisor \\ Dr. Andrea Raucsikné Varga
}

assistant professor, Department of Mineralogy, Geochemistry and Petrology

Consultant

Dr. Réka Haranginé Lukács

researcher, MTA-ELTE Volcanology Research Group
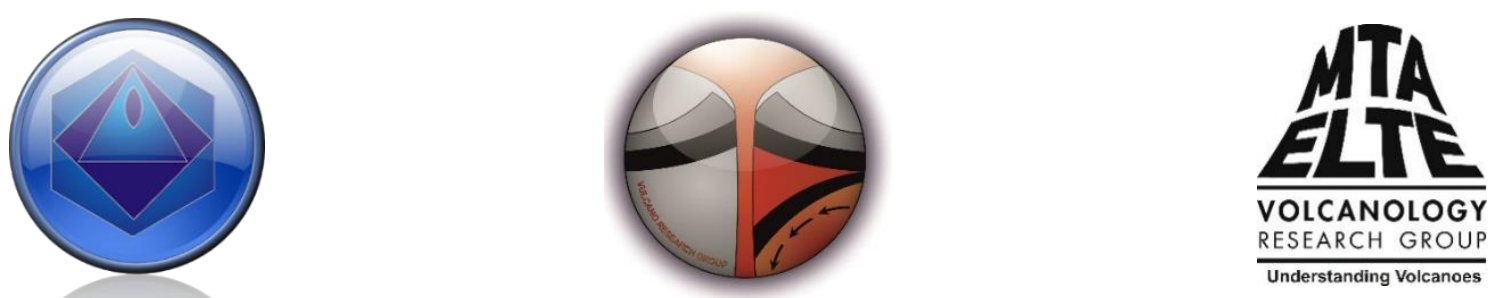

Department of Mineralogy, Geochemistry and Petrology

Faculty of Science and Informatics

University of Szeged

2020

Szeged 


\section{ADY ENDRE}

\section{A föl-földobott kő}

Föl-földobott kö, földedre hullva, Kicsi országom, újra meg újra Hazajön a fiad.

Messze tornyokat látogat sorba, Szédül, elbúsong s lehull a porba, Amelyböl vétetett.

Mindig elvágyik s nem menekülhet, Magyar vágyakkal, melyek elülnek $\mathrm{S}$ fölhorgadnak megint.

Tied vagyok én nagy haragomban, Nagy hütlenségben, szerelmes gondban Szomorúan magyar.

Föl-fölhajtott kő, bús akaratlan, Kicsi országom, példás alakban Te orcádra ütök.

És, jaj, hiába, mindenha szándék, Százszor földobnál, én visszaszállnék, Százszor is, végül is.

\section{ENDRE ADY}

\section{The tossed stone}

As does the tossed stone fall to the ground, My tiny country, so each time around, Your son comes home to stay.

Far away towers he visits, he must, Giddily, sadly, he falls to the dust, The dust from whence he came.

Longing to leave, but unable to flee, Magyar desires, though fading they be, Rise, take over again.

In my great anger to you I belong, In cares of love and in each faithless wrong, I'm sadly, a Magyar.

Like stone lacking will when hurled in the air, With exemplary form, my land, I dare To slap your countenance.

Woe, my intentions are ever in vain, Each time you toss me, I'll fly back again, Many times, till it ends.

Kery, Leslie A. 


\section{TABLE OF CONTENTS}

CHAPTER I: INTRODUCTION

1.1. LATE PALAEOZOIC VOLCANISM IN THE CARPATHIAN-PANNONIAN REGION, CENTRAL EUROPE: WHERE AND WHEN DID IT OCCUR?

1.2. THE GYÜRŰFŰ RHYOLITE FORMATION: WHY WAS IT IMPORTANT TO BE

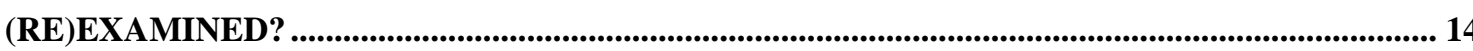

1.3. ALTERED VOLCANIC ROCKS: HOW TO START DEALING WITH THEM? 15

1.4. AIMS AND THE STRUCTURE OF THE DISSERTATION: WHAT KIND OF METHODS WERE APPLIED AND HOW WERE THEY DOCUMENTED?

CHAPTER II: PETROGRAPHY OF THE GYÜRÜFÜ RHYOLITE FORMATION, SOUTHERN TRANSDANUBIA, HUNGARY .........................20

2.1. INTRODUCTION, PREVIOUS RESULTS ......................................................................................... 20

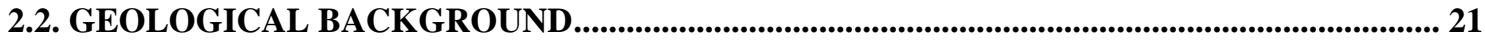

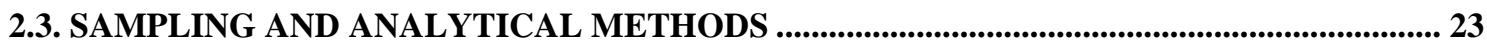

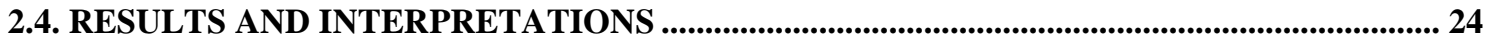

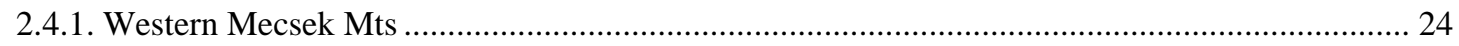

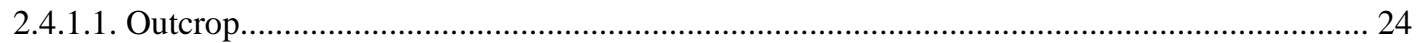

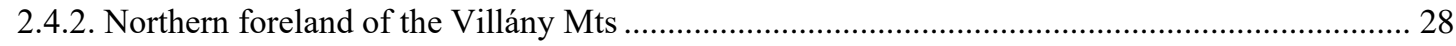

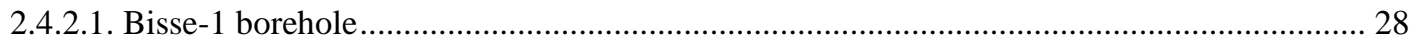

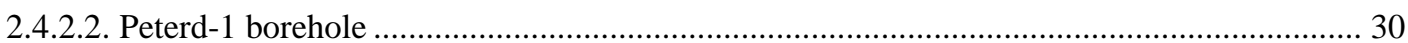

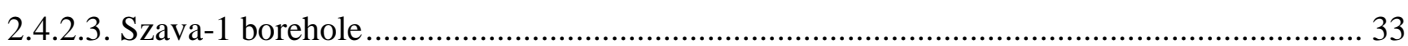

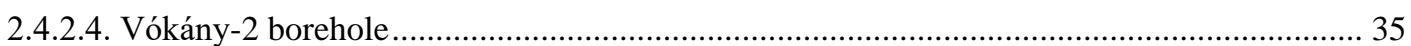

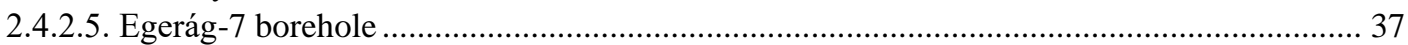

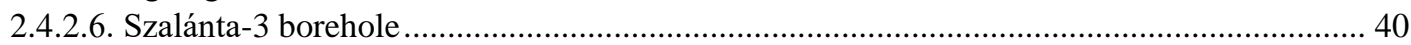

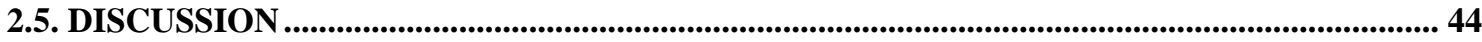

CHAPTER III: LAVAS OR IGNIMBRITES? PERMIAN FELSIC VOLCANIC ROCKS OF THE TISZA MEGA-UNIT (SE HUNGARY) REVISITED: A

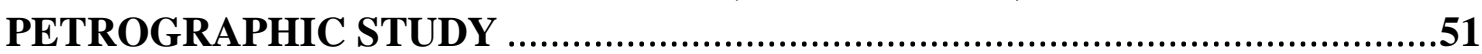

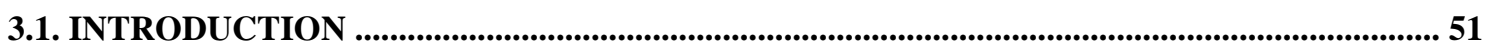

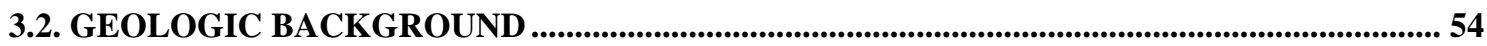

3.3. MATERIALS AND METHODS ......................................................................................................... 56

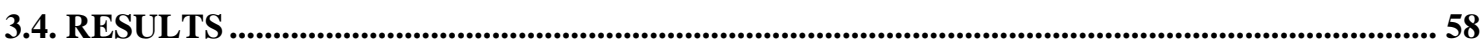

3.4.1. Eutaxitic, massive, matrix-supported, porphyric, fiamme-bearing lapilli tuffs (emLT) .............. 59

3.4.2. Felsitic, matrix-supported, porphyric, fiamme-bearing rheomorphic lapilli tuffs (rheoLT) ......... 61

3.4.3. Matrix-supported, fine-grained, felsitic ash tuff with coated-particles (accfrichT) ....................... 64

3.4.4. Lithic-rich, massive, strongly sericitized, poorly-sorted volcaniclastics $(\operatorname{lmLT})$.......................... 66

3.4.5. Spherulitic, vitrophyric lava-like ash tuffs (vlava-likeT) .......................................................... 70

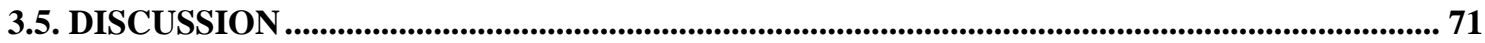


3.5.1. Petrographic (re)interpretations according to the new observations and archive reports ............ 71

3.5.2. Syn and post emplacement textural development.......................................................... 73

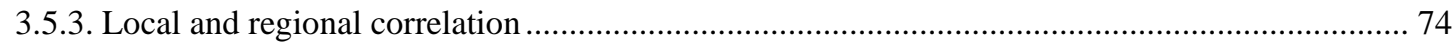

3.5.4. Emplacement of the Permian felsic volcanic rocks in SE Hungary within the Permian volcanic

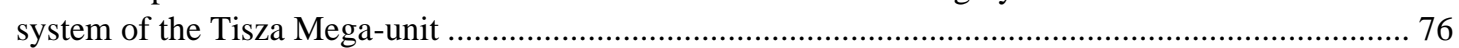

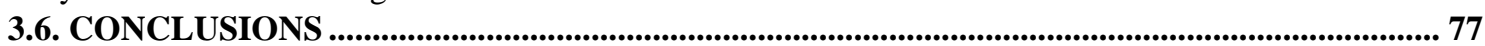

\section{CHAPTER IV: PERMIAN FELSIC VOLCANIC ROCKS IN THE PANNONIAN \\ BASIN (HUNGARY): NEW PETROGRAPHIC, GEOCHEMICAL, AND

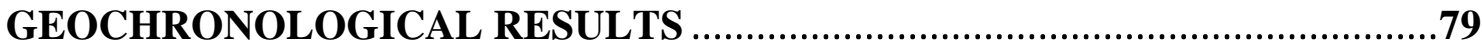

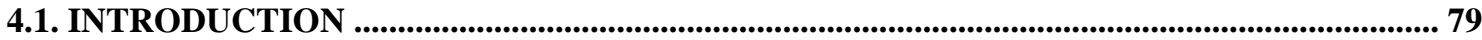

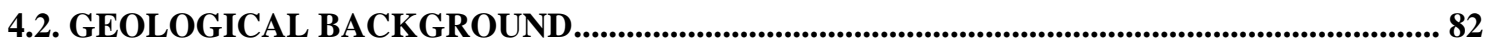

4.3. SAMPLING AND ANALYTICAL METHODS ..................................................................85

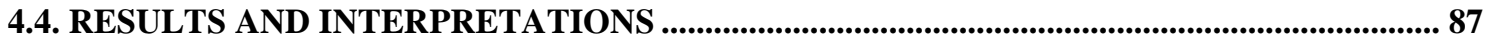

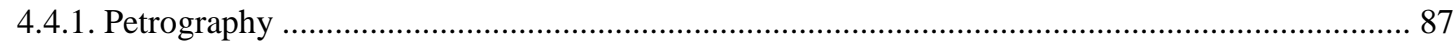

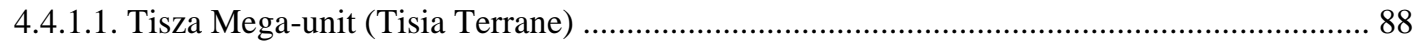

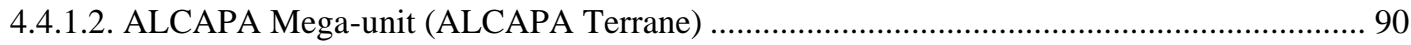

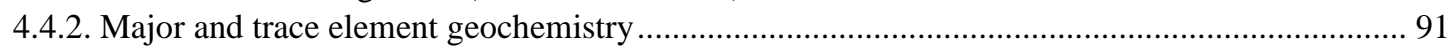

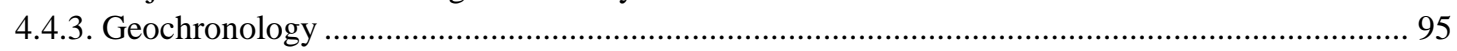

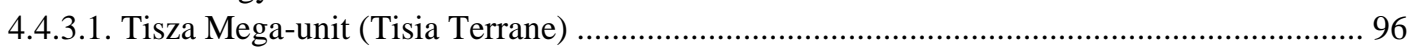

4.4.3.2. ALCAPA Mega-unit (ALCAPA Terrane) …............................................................. 98

4.5. DISCUSSIONS AND INTERPRETATIONS .............................................................................. 98

4.5.1. Genetic interpretations based on petrography and whole-rock geochemistry .......................... 99

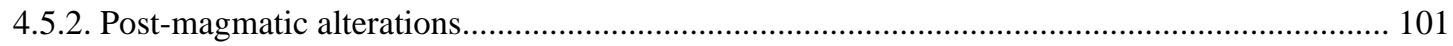

4.5.3. Tectonic implications and the potential source of the magmatism ........................................ 103

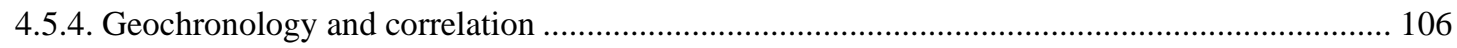

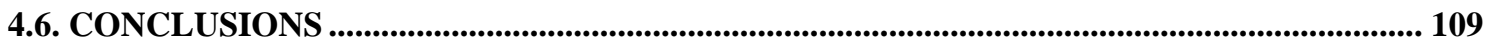

CHAPTER V: CONCLUSIONS ..............................................................

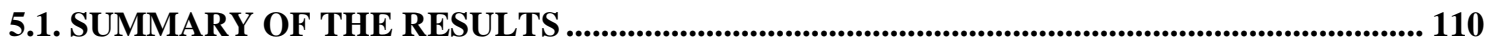

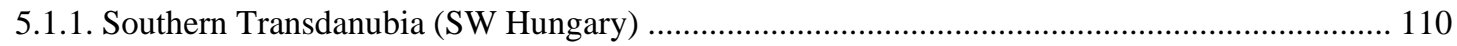

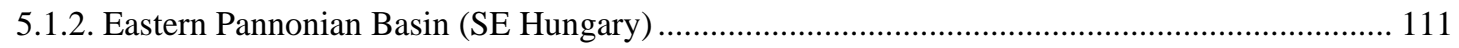

5.1.3. The Permian volcanic system forming the Gyürüfü Rhyolite Formation............................... 113

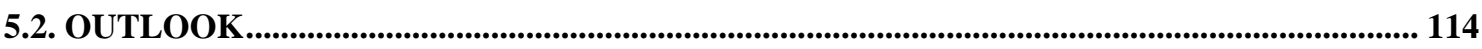

5.2.1 Regional correlation in the Carpathian-Pannonian region .................................................... 114

5.2.2. Recondsideration of the Mesozoic facies zones in the Tisza Mega-unit ................................ 116

SUMMARY

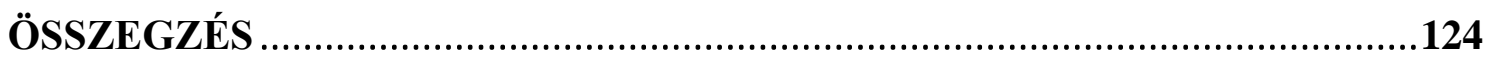

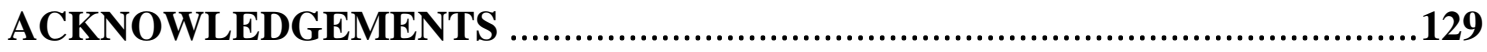

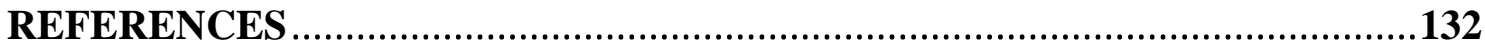

SUPPLEMENTARY FIGURES .......................................................... 145

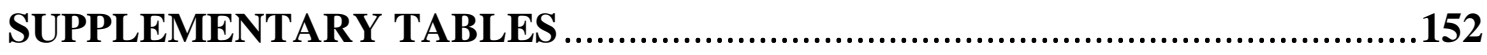




\section{LIST OF FIGURES}

Figure I.1 Distribution of the Permian felsic volcanic rocks in the Carpathian-Pannonian region, pointing out the occurrences of the Gyürüfü Rhyolite Formation (red) studied in the $\mathrm{PhD}$ research and the analogous formations of the region that were compared to them (blue). Index map (below) shows the Alpine facies zones in the basement of the Tisza Mega-unit. $B$ Battonya, Kel Kelebia, Kk Kékkút-4 well, $M B$ Máriakéménd-Báta Basement Range, $N V$ northern foreland of the Villány Mts, $P$ Polgárdi quarry, $W M$ Western Mecsek Mts, $M U$ Mecsek Unit, $V B U$ Villány-Bihor Unit, $B C U$ Békés-Codru Unit. ...

Figure II.1 Regional distribution of the Gyürüfü Rhyolite Formation in Southern Transdanubia, displaying the most significant boreholes that explored the formation (based on Barabásné Stuhl 1988). 1 hills/moutains, 2 the subsurface distribution of the Gyürüfü Rhyolite Formation, 3 frontier, 4 borehole.....21

Figure II.2 Photomicrographs of the eutaxitic, welded, crystal-rich, pumice-bearing lapilli tuffs, Western Mecsek Mts, outcrop. a Oriented pumices with axiolites at the rims and spherulites inside them, and opaque pseudomorphs after pyroxene; b Opaque pseudomorph after biotite inside an altered pumice; $\mathbf{c}$ Fragmented feldspar phenocrysts (plagioclase above, K-feldspar below); d Spherulites as high temperature crystallization domains; e Oriented, altered glass shards in the fine-grained groundmass; f Subhedral, resorbed quartz phenocryst and an altered, devitrified pumice. $a x$ axiolite, $b t$ opaque pseudomorph after biotite, $f l$ fluid inclusion assemblages, $f s p$ feldspar, $p$ altered pumice, $p x$ opaque pseudomorph after pyroxene, $q z$ quartz, $s$ altered glass shard, $s p h$ spherulite, $z r n$ zircon, $1 N$ plane polarized light, $+N$ crossed polars.

Figure II.3 Photomicrographs of the non-welded, crystal-rich, pumice-bearing lapilli tuffs, Western Mecsek Mts, outcrop. a Subhedral, resorbed quartz with fluid inclusion assemblages, axiolitic pumice, and a sedimentary lithic clast; b Subhedral, fragmented feldspar phenocryst; c Plagioclase (above) and Kfeldspar (below); d Altered pumice with axiolites at the rims and opaque pseudomorphs after biotite; e Poorly-oriented texture with altered pumices and glass shards; $\mathbf{f}$ X and Y shaped glass shards in the matrix. aln allanite, $a x$ axiolite, $b t$ opaque pseudomorph after biotite, $f l$ fluid inclusion assemblages, $f s p$ feldspar, $p$ altered pumice, $p x$ opaque pseudomorph after pyroxene, $q z$ quartz, $s$ altered glass shard, $1 N$ plane polarized light, $+N$ crossed polars.

Figure II.4 Photomicrographs of the studied samples of the Bisse-1 borehole (depth: $1100 \mathrm{~m}$ ). a Relict perlitic texture with porphyric feldspar and biotite crystals; b Characteristic relict perlitic texture; c Subhedral quartz and biotite in a relict perlitic sample; $\mathbf{d}$ K-feldspar (above) and plagioclase (below) in a fine-grained groundmass; e Argillitized euhedral, tabular plagioclase; f Microcrystalline, relict perlitic groundmass with remnants of oriented, altered pumices and fragments of feldspar crystals. $b t$ biotite, $f_{s p}$ feldspar, $p$ altered pumice, $q z$ quartz, $1 N$ plane polarized light, $+N$ crossed polars.

Figure II.5 Photomicrographs of the studied samples of the Peterd-1 borehole (depths: $1240.0 \mathrm{~m}$ and unknown). a Typical textural image with porphyric, subhedral phenocrysts and altered pumices; b Devitrified pumice with axiolites at the rims; c Altered glass shards in the fine-grained groundmass; d Subhedral, resorbed quartz with fluid inclusion assemblages inside; e Resorbed quartz, fragmented feldspar, euhedral biotite and accessory zircon; f Pectinate feldspar (adularia) and altered pyroxene. $a x$ axiolite, $b t$ biotite, $f l$ fluid inclusion assemblages, $f s p$ feldspar, $p$ altered pumice, $p x$ pyroxene, $q z$ quartz, $s$ altered glasss shards, $z r n$ zircon, $1 N$ plane polarized light, $+N$ crossed polars. The scale of the blowup picture $(\mathbf{d})$ is 50

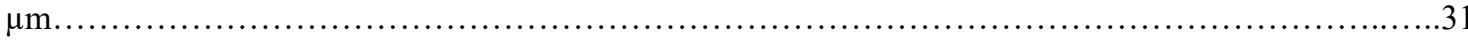

Figure II.6 Photomicrographs of the studied samples of the Szava-1 borehole (depth: $353.5-477.8 \mathrm{~m}$ ). a Porphyric microholocrystalline texture with subhedral quartz and feldspar crystals; b Sample having granophyric texture; c Vein, filled with carbonate crosscutting the sample; d Euhedral, mildly resorbed quartz; e Altered, subhedral feldspar crystal; f Biotite crystal, faded and partially replaced by opaque minerals. $b t$ biotite, $c b$ carbonate, $f s p$ feldspar, $q z$ quartz, $1 N$ plane polarized light, $+N$ crossed polars.....33

Figure II.7 Photomicrographs of the studied samples of the Vókány-2 borehole (a-d depths: $1000.0 \mathrm{~m}$ and $1139.6 \mathrm{~m}$; e-f depht: $774.8 \mathrm{~m}$ ). a Recrsytallized groundmass with spherulites and a biotite crystal; b Porphyric crystals in a sample having felsitic texture; c Subhedral, resorbed, fragmented quartz crystals; d K-feldspar in a sericitized sample having felsitic texture; $\mathbf{e}$ Altered glass shards and pumices in a pyroclastic sample; f Altered pumices replaced by mosaic quartz, and a lithic clast in a pyroclastite sample. $b t$ biotite, 
$f s p$ feldspar, $L$ lithic clast, $p$ altered pumice, $q z$ quartz, $s$ altered glass shard, sph spherulite, $1 N$ plane

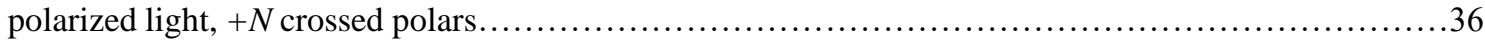

Figure II.8 Photomicrographs of the studied samples of the Egerág-7 borehole (a-d depth: 673.3-753.8 m; e-f depth: 1200 m). a Oriented, devitrified pumices, fragmented feldspar and biotite crystals; $\mathbf{b}$ Altered pumice with axiolites at the rims and spherulites inside it, and fragmented, subhedral crystals; $\mathbf{c}$ Oriented, altered pumices and devitrified glass shards; $\mathbf{d}$ K-feldspar and altered pyroxenes; e Quartz crystal having fringy margin; f Porphyric plagioclase in a sample having microholocrystalline texture. $a x$ axiolite, $b t$ biotite, $f s p$ feldspar, $p$ altered pumice, $p x$ pyroxene, $q z$ quartz, $s$ altered glass shard, $s p h$ spherulite, $z r n$

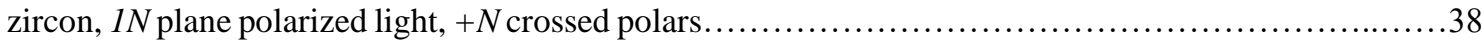

Figure II.9 Photomicrographs of the studied samples of the Szalánta-3 borehole (a-d depth: 299.0-404.8 $\mathrm{m}$ and $505.5 \mathrm{~m}$; e-f depths: 459.3 and $548.7 \mathrm{~m}$ ). a Altered pumices, subhedral, resorbed quartz and biotite replaced by opaque minerals; $\mathbf{b}$ Subhedral, fragmented quartz and feldspar crystals, and altered glass shards, c Altered pumices, replaced by mosaic quartz and resorbed or fragmented crystals around them; $\mathbf{d}$ Clots of biotite/chlorite, quartz, feldspar and opaque minerals in a felsitic volcanic rock; e Porphyric K-feldspar having fringy rims; $\mathbf{f}$ Crown-like structure of biotite crystals around an opaque mineral, and a subhedral plagioclase. $a p$ apatite, $a x$ axiolite, $b t$ biotite, $c b$ carbonate, $c h l$ chlorite, $f l$ fluid inclusion assemblages, $L$ lithic clast, $o p q$ opaque mineral, $p$ altered pumice, $q z$ quartz, $s$ altered glass shard, $1 N$ plane polarized light, $+N$ crossed polars

...41

Figure II.10 The hypothetical position of the two distinct lithofacies in the Western Mecsek Mts, Gyürüfü area (outcrop) within the valley-filling pyroclastic flow (ideal section, based on McArthur et al. 1998).....45

Figure II.11 Lithological columns of the Permian volcanic sequences at the northern foreland of the Villány Mts. Observed rocks (thin sections) are listed in the 'List of samples': samples of the 'Volcanites, etalon collection' were marked by numbers, while samples of the collection of the Eötvös Loránd University were marked by Via-X labels; in both cases the identifier numbers of the appropiate collections were used (see

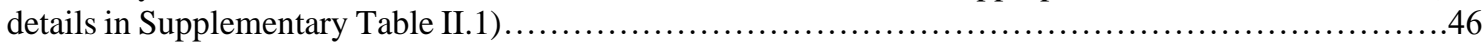

Figure III.1 Tectonic sketch of the Pannonian Basin, pointing out the surface and subsurface distribution of the Permian felsic volcanic rocks (a), highlighting the subsurface occurrences in SE Hungary (b), especially in the Battonya area (c). Map base is modified after Szemerédi et al. (2020a). Bat Battonya, Kel

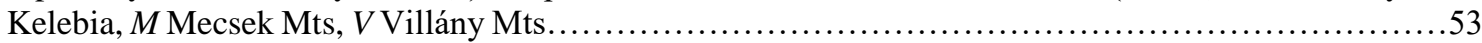

Figure III.2 Basement formations in the eastern Pannonian Basin (SE Hungary, Tisza Mega-unit, BékésCodru Unit), pointing out the most significant Battonya area (black rectangle) and two of the studied boreholes. T-I Tótkomlós-I, T-K-3 Tótkomlós-K-3 (modified after Kurucz 1977; T. Kovács and Kurucz 1984)........ .55

Figure III.3 Photomicrographs of the eutaxitic, massive, matrix-supported, porphyric, fiamme-bearing lapilli tuffs (emLT), Battonya area. a Sample ÁGK-1830, eutaxitic texture defined by deformed, elongated glass shards with subhedral quartz and feldspar phenocrysts; b Sample ÁGK-1830, oriented, devitrified fiammes replaced by mosaic of quartz and feldspar microcrysts; c Sample ÁGK-1821, subhedral, resorbed, porphyric quartz surrounded by deformed glass shards; d Sample ÁGK-1821, subhedral quartz crystal with deformation lamellae; e Sample ÁGK-1830, subhedral, resorbed quartz, K-feldspar (above) and plagioclase (below) phenocrysts and devitrified fiamme replaced by mosaic of quartz and feldspar; f Sample ÁGK1831, devitrified fiamme with axiolites at the rims and spherulites inside it, in a brecciated sample. $a x$ axiolite, $f$ altered fiamme, $f s p$ feldspar, $q z$ quartz, $s$ altered glass shard, $s p h$ spherulite, $P P L$ plane polarized light, $X P L$ crossed polars.

Figure III.4 Photomicrographs of the felsitic, matrix-supported, porphyric, fiamme-bearing rheomorphic lapilli tuffs (rheoLT), Battonya area, sample ÁGK-1274 (Battonya-50 borehole), highlighting apparent coherent texture $(\mathbf{a}-\mathbf{c})$ and oriented (eutaxitic) parts $(\mathbf{d}-\mathbf{f})$ of the sample. $\mathbf{a}-\mathbf{c}$ Homogeneous groundmass with mosaics of quartz and feldspar microcrysts (crystalloclasts and devitrified glass shards) and subhedral, resorbed phenocrysts; $\mathbf{d}-\mathbf{f}$ Remnants of oriented fiammes referring to rheomorphic flow that postdate or might have occurred during the ignimbrite emplacement and deposition. Note: significant differences in the size of the phenocrysts and the presence of some angular, broken crystals (crystalloclasts pointed by 
red arrows). $\quad f$ altered fiamme, $f s p$ feldspar, $q z$ quartz, $\quad X P L \quad$ crossed

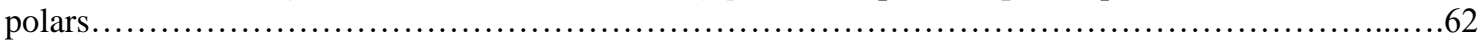

Figure III.5 Photomicrographs showing the states of the ignimbrite grade continuum from eutaxitic welded ignimbrites to high-grade rheomorphic ignimbrites (emLT and rheoLT). a-b Eutaxitic ignimbrites (emLT, sample ÁGK-1830 and 1821, respectively), containing fiammes with well-visible, definite edge and finegrained groundmass crystals (devitrified glass shards and crystalloclasts); c-d Moderately rheomorphic ignimbrites (rheoLT, sample ÁGK-1790), containing fiammes with visible edge and coarser groundmass crystals; e-f Strongly rheomorphic, extremely high-grade ignimbrites, containing fiammes with barely visible edge and coarser groundmass crystals (rheoLT, sample ÁGK-1243). $f s p$ feldspar, $q z$ quartz. XPL crossed polars. Altered, devitrified fiammes are highlighted by orange dashed lines....

.64

Figure III.6 Photomicrographs of the matrix-supported, fine-grained, felsitic ash tuff with coated-particles (accfrichT: a-c) and the spherulitic, vitrophyric lava-like ash tuffs (vlava-likeT: e-f), Battonya and Tótkomlós areas, respectively. a-c Sample Bat-7 (Via-79), coated particles (armored pellets) formed around subhedral, resorbed quartz crystals; d Sample T-I 14 MF, subhedral, porphyric quartz and spherulites in the matrix; e Sample T-I 14 MF, completely spherulitic groundmass; f Sample T-I 13 MF, subhedral quartz and sericitized feldspar crystals in the matrix affected by pervasive crystallization. $f s p$ feldspar, $q z$ quartz, sph spherulite, $P P L$ plane polarized light, $X P L$ crossed polars.

Figure III.7 Photomicrographs of the lithic-rich, massive, strongly sericitized, poorly-sorted volcaniclastics $(\operatorname{lmLT})$, Biharugra and Tótkomlós areas. a Sample BATR/1, poorly-sorted volcaniclastite, containing sericizited fiammes and angular fragments of quartz; b Sample ÁGK-1340-2, subhedral, resorbed magmatic quartz and euhedral biotite crystals; c Sample ÁGK-1339, subhedral polysynthetic plagioclase (left) and K-feldspar (right) crystals; d Sample ÁGK-1340-2, fragmented quartz and euhedral biotite crystals; e Sample ÁGK-1267, muscovite and felsic volcanic lithic clast, having felsitic texture; f Sample BATR/1, microcline, broken quartz crystals and sericitized juvenile fragments. $b t$ biotite, $f$ altered fiamme, $f s p$ feldspar, $L$ lithic clast, $m c$ microcline, $m s$ muscovite, $q z$ quartz, $P P L$ plane polarized light, $X P L$ crossed polars.

Figure III.8 Volcanic (a-d) and non-volcanic (e-f) lithics from the lithic-rich, massive, strongly sericitized, poorly-sorted volcaniclastics ( $\operatorname{lmLT}$ ). a Sample ÁGK-1267, felsic lithic clast, having felsitic, spherulitic texture; b Sample ÁGK-1340, quartz-feldspar-biotite porphyric lithic clast, having fine groundmass; c Sample ÁGK-1339, felsic lithic clast, containing recognizable oriented juvenile components (glass shards); pyroclastite clast; d Sample ÁGK-1267, dark-colored, fine-grained, hematitized (maficintermediate?) lithic clast; e Sample BATR/1, fine-grained sedimentary lithic clast (claystone or siltstone); f Sample ÁGK-1267, polycrystalline metamorphic quartz. $b t$ biotite, $f s p$ feldspar, $q z$ quartz, $s$ altered glass shard, $P P L$ plane polarized light, $X P L$ crossed polars

Figure III.9 The relative timescale of the most significant processes in the textural development of the Permian felsic volcanic rocks. Each process is marked by its representative lithofacies (modified after Lofgren 1971; Swanson et al. 1989; Stevenson et al. 1994; Orth and McPhie 2003; Breitkreuz 2015).

Figure III.10 Correlation between the Alpine facies zones of the Tisza Mega-unit (Hungary) and the tectonic units of the Apuseni Mts, highlighting the results of Szepesházy (1979). Data are based on Szederkényi (2013), Nicolae et al. (2014) and Szemerédi et al. (2020a)....

Figure IV.1 a Tectonic sketch of the Carpathian-Pannonian region indicating the subsurface contour of the mega-units. b Position of the studied Permian felsic volcanic rock outcrop and the boreholes of Southern Transdanubia, Hungary. Map base is modified after Szemerédi et al. (2017). B Battonya, Kel Kelebia, Kk Kékkút, $P$ Polgárdi. .81

Figure IV.2 Photomicrographs of the Permian felsic volcanic rocks, Tisza Mega-unit and ALCAPA Megaunit, Hungary: a Sample GYRFP, pyroclastite (Western Mecsek Mts, outcrop): parallel pumices with axiolites at the margins and spherulites inside them together with opaque pseudomorphs after pyroxene. b Sample Somberek-1, pyroclastite (Máriakéménd-Báta Basement Range, borehole): fragmented quartz, feldspar and biotite crystals in a welded ignimbrite. c Sample Szalánta-3, pyroclastite (northern foreland of the Villány Mts): subhedral, chloritized and fragmented garnet showing intergrowth with potassium 
feldspar. d Sample GYR K2, pyroclastite (Western Mecsek Mts, outcrop): X- and Y-shaped glass shards in the matrix of a non-welded ignimbrite. e Sample ÁGK-1830, pyroclastite (Battonya-Pusztaföldvár Basement Ridge, borehole): subhedral quartz and feldspar crystals in a strongly welded ignimbrite. $\mathbf{f}$ Sample Vókány-2, lava (northern foreland of the Villány Mts, borehole): felsitic texture with subhedral, resorbed and fractured quartz crystals. g Sample Polgárdi, dyke (Central Transdanubia, Polgárdi quarry): porphyric plagioclase and pseudomorph after biotite with resorbed quartz. h Sample Polgárdi, dyke (Central Transdanubia, Polgárdi quarry): mosaic quartz and pseudomorph after biotite in mosaic quartz-sericite groundmass. $a x$ axiolite, $b t$ pseudomorph after biotite, $c h l$ chlorite, $f s p$ feldspar, grt garnet, $p$ altered pumice, $p x$ pseudomorph after pyroxene, $q z$ quartz, $s$ altered glass shard, $s p h$ spherulite, $P P L$ plane polarized light, $X P L$ crossed polars.

Figure IV.3 Classification of the Permian volcanic rocks of the Tisza Mega-unit, the ALCAPA Mega-unit, Hungary and the analogous formations of the European Variscides in total alkali silica (TAS) diagrams (Le Maitre et al. 1989), based on new (a) and archive (b) geochemical data (Fazekas 1978; Barabásné Stuhl 1988; Fülöp 1990, 1994) with the number of the previous geochemical analyses (n). Comparative data derive from the following authors: Apuseni Mts: felsic volcanic rocks (Nicolae et al. 2014); Northern Gemeric Unit: rhyolites-dacites (Vozárová et al. 2015); Southern Gemeric Unit: rhyolites (Vozárová et al. 2009); Northern Veporic Unit: volcanic rocks and tonalite dyke (Vozárová et al. 2016); Intra-Sudetic Basin: felsic rocks, younger and older volcanic suites (Awdankiewicz 1999); Northeast Germany: rhyodacites (Paulick and Breitkreuz 2005); Highiş massif, Apuseni Mts: Păuliş Granites (Pál-Molnár et al. 2008); Average Palaeozoic felsic volcanic rock composition: Condie (1993).

Figure IV.4 Classification of the studied Permian volcanic rocks of the Tisza Mega-unit, the ALCAPA Mega-unit, Hungary and the analogous formations of the European Variscides in the $\mathrm{Zr} / \mathrm{TiO}_{2} \mathrm{vs}$. $\mathrm{Nb} / \mathrm{Y}$ diagram (Winchester and Floyd 1977). The references of the comparative data are the same as those in Fig. IV.3. .93

Figure IV.5 Chondrite-normalized rare earth element (REE) patterns and multi-element spider diagrams (Sun and McDonough 1989) of the Permian volcanic rocks of the Tisza Mega-unit, the ALCAPA Megaunit, Hungary and two of the analogous formations of the European Variscides (Apuseni Mts, Romania and Northern Veporic Unit, Slovakia; Nicolae et al. 2014; Vozárová et al. 2016). The latter play important role in the regional correlation (see details in "Geochronology and correlation"). Note fractionated light (L)REE, negative Eu anomaly and nearly flat heavy (H)REE pattern. The symbols are the same as those in Fig. IV.3.

Figure IV.6 Results of the zircon U-Pb geochronology of the Permian volcanic rocks. The TuffZirc algorithm (Ludwig 2002) was applied in order to identify the mean age of the the youngest coherent age component. a Gy-1 sample (Western Mecsek Mts, outcrop), b Szava-1 sample (northern foreland of the Villány Mts, borehole), c, d BATR/1 and BATR/2 samples (Battonya-Pusztaföldvár Basement Ridge, borehole), e Kelebia-7 sample (Kelebia area, borehole), f PR-1 sample (Polgárdi quarry, dyke)...... . .97

Figure IV.7 $\mathrm{Na}_{2} \mathrm{O} / \mathrm{Al}_{2} \mathrm{O}_{3}$ vs. $\mathrm{K}_{2} \mathrm{O} / \mathrm{Al}_{2} \mathrm{O}_{3}(\mathbf{a}), \mathrm{Na}_{2} \mathrm{O} / \mathrm{K}_{2} \mathrm{O}$ vs. $\mathrm{SiO}_{2} / \mathrm{Al}_{2} \mathrm{O}_{3}$ (b; Garrels and Mackenzie 1971) and $\mathrm{Na}_{2} \mathrm{O}$ vs. $\mathrm{K}_{2} \mathrm{O}$ diagrams (c; Paulick and Breitkreuz 2005) focusing on the post-magmatic alterations of Permian volcanic rocks of the Tisza Mega-unit, the ALCAPA Mega-unit, Hungary and the analogous formations from the European Variscides. The references of the comparative data are the same as those in Fig. IV.3. 102

Figure IV.8 Nb-Y (a; Pearce et al. 1984) and Th/Yb vs. Ta/Yb (b; Gorton and Schandl 2000) discrimination diagrams and $\mathrm{La}_{\mathrm{N}} \mathrm{vs}$. $\mathrm{La}_{\mathrm{N}} / \mathrm{Yb}_{\mathrm{N}}$ diagram (c) for the Permian volcanic rocks of the Tisza Mega-unit, the ALCAPA Mega-unit, Hungary and the analogous formations of the European Variscides. $O R G$ ocean ridge granites, syn-COLG syn-collision granites, VAG volcanic arc granites, WPG within-plate granites, $O A$ oceanic arcs, $A C M$ active continental margins, WPVZ within-plate volcanic zones, WPB within-plate basalts, MORB mid-ocean ridge basalts, $N-M O R B$ Mid Ocean Ridge Basalt (Sun and McDonough 1989), OIB Ocean Island Basalt (Sun and McDonough 1989), CC average continental crust (Rudnick and Fountain 1995). The references of the comparative data are the same as those in Fig.

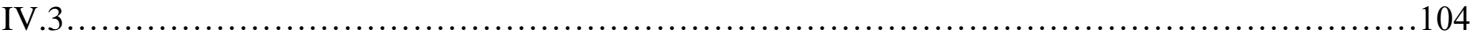

Figure IV.9 Radiometric age data of Permian felsic volcanic rocks of the European Variscides, summarizing all magmatic events that are significant for the correlation of the Permian felsic volcanic rocks 
in Hungary (Pană et al. 2002; Lelkes-Felvári and Klötzli 2004; Vozárová et al. 2009, 2015, 2016; Kelemen et al. 2017; Ondrejka et al. 2018). The U-Pb zircon age of this study are bold and underlined. Carb. Carboniferous, Ear. Early Triassic, Guadal. Guadalupian, Loping. Lopingian, Penn. Pennsylvanian, HU Hungary, $R O$ Romania, SK Slovakia......

Figure IV.10 Permian felsic magmatic events in the Carpathian-Pannonian region (a) displayed by weighted mean ages (Ma), highlighting crustal-scale superunits of the Western Carpathians and representative ages (b, modified after Kohút et al. 2013). Index map shows the Alpine facies zones of the study area (modified after Szederkény et al. 2013). $M U$ Mecsek Unit; VBU Villány-Bihor Unit; $B C U$ Békés-Codru Unit; $N G U$ Northern Gemeric Unit; $S G U$ Southern Gemeric Unit. Results derive from Pană et al. (2002), Lelkes-Felvári and Klötzli (2004), Vozárová et al. (2009, 2015, 2016), Ondrejka et al. (2018)

Figure V.1 A possible correlation between the Mesozoic facies zones in the basement of the Tisza Megaunit (Hungary) and the similar structural zones in the Apuseni Mts (Romania), highlighting the new results of the Kelebia area. Symbols used for the subsurface occurrences of the Gyürüfü Rhyolite Formation are as those in Chapter IV. Map base is modified after Matenco and Radivojević (2012)..... 118

\section{LIST OF TABLES}

Table I.1 Table of the most significant terms used in the petrographic descriptions and interpretations, explaining their meaning. Some references are given by each expression.

Table II.1 A summarizing table of boreholes (subsurface region, base, top, minimum thickness), exploring the Gyürüfü Rhyolite Formation in the area of Southern Transdanubia.

Table III.1 The most important data of the studied samples and boreholes in SE Hungary and the summary of the results of the archive reports and this study. Samples with available whole-rock (major and trace elements) geochemical data are put in italics and bold, while samples with zircon $\mathrm{U}-\mathrm{Pb}$ ages are highlighted by asterisk (data in Szemerédi et al. 2020a; see details in Chapter IV). Lithofacies (Lf) description are listed in Table III.2.

Table III.2 Terminology used for the characterization of the lithofacies of the Permian felsic volcanic rocks in SE Hungary (modified after Branney and Kokelaar 2002; Sommer et al. 2013). ...

Table III.3 Modal (volume) proportions (in \%) of rock-forming minerals, fiammes, as well as the groundmass, measured quantitatively at least, on one selected representative sample of each distinct lithofacies. The meaning of the abbreviations applied for the lithofacies (facies code) are described in Table III.2. $b t$ biotite, $c p$ coated particle, $f$ fiamme, $g$ groundmass, $k f s$ K-feldspar, $L_{v}$ volcanic lithic clast, $L_{n v}$ nonvolcanic lithic clast, $p l$ plagioclase, $q z$ quartz. *In case of lithic-rich, massive, strongly sericitized, poorlysorted volcaniclastics strongly sericitized groundmass and altered juvenile fragments (fiammes and glass shards) were indistinguishable and given together as groundmass.

Table III.4 Summary of the most significant textural features observed by each lithofacies of the Permian felsic volcanic rocks in SE Hungary. Abbreviations are listed in Tables III.2 and III.3. fsp feldspar, $q z$ quartz, ser sericite, + rare, ++ moderate, +++ frequent, - not present.

Table IV.1 Most important information about the studied Permian felsic volcanic rocks of the Tisza Megaunit and the ALCAPA Mega-unit, Hungary. The selected 20 outcrop/boreholes of recent study with wholerock geochemical data are underlined. Pale grey: Mecsek Unit, grey: Villány-Bihor Unit, dark grey: BékésCodru Unit.

Table IV.2 Compilation of the zircon, in-situ geochronological results obtained on the Permian felsic volcanic rocks from the Tisza Mega-unit and the ALCAPA Mega-unit. ${ }^{a}$ Discordant and outlier data free concordia ages of IsoplotR except for Gy-1 which result stands for the youngest age component of the IsoplotR mixing model...... 
Table IV.3 Petrographic classifications (based on the mineralogical, major element and immobile trace element compositions) of the studied Permian volcanic rock samples from the Tisza Mega-unit and the ALCAPA Mega-unit. .100

Table V.1 Correlation between the Alpine facies zones of the Tisza Mega-unit (Hungary) and the tectonic units of the Apuseni Mts (Romania) in the aspect of the Permian felsic volcanic rocks. Data are based on Szederkényi (2013), Nicolae et al. (2014) and all the new results associated with the doctoral research (e.g., Szemerédi et al. 2018b, 2020c). .117

\section{LIST OF SUPPLEMENTARY FIGURES}

Supplementary Figure II.1 Structural framework and generalized geological map of the Western Mecsek Mts after Konrád and Sebe (2010), showing the locality where the observed Gyürüfü Rhyolite (GYRF) samples were collected (a) with the sketch of the sampling sites (b) in the area of the villages of Gyürüfü and Dinnyeberki. Legends: a 1 Neogene, 2 Jurassic and Cretaceous, 3 Triassic, 4 Upper Permian-Lower Triassic, 5 Palaeozoic in general, 6 observed fault, 7 compiled fault, 8 observed reverse fault, 9 compiled reverse fault, 10 strike-slip fault, 11 syncline, 12 anticline; $\mathbf{b} 1$ settlement, 2 forest road, driveway, 3 hiking trail, valley (passable for pedestrians), 4 watercourse, 5 spring, 6 detrital outcrop, 7 outcrop in situ

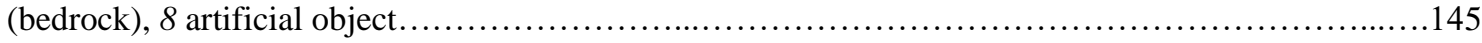

Supplementary Figure II.2 Gyürüfü, Istenkút sampling site (a) and the macroscopic appearance of the exposed rock samples $(\mathbf{b}-\mathbf{d})$. The altered pumices are delimited by red dashed lines......................146

Supplementary Figure II.3 Rock samples of Gyürüfü Rhyolite from outcrops (both in situ and detrital material) situated along the road from Dinnyeberki to Gyürüfü (a-d) and the scanned images of three observed thin sections: Gyürüfü, Tree 1 (Tree 1), Gyürüfü, Istenkút outcrop $(I K)$ and a detrital sample near Gyürüfü $(K 2)$. a and b Gyürüfü Tree 1 sampling site; c Gyürüfü, Tree 2 sample; d Representative detrital sample near Gyürüfü. The altered pumices are delimited by red dashed lines.

Supplementary Figure II.4 Macroscopic appearance of the Gyürüfü Rhyolite Formation at the northern foreland of Villány Mts. a Peterd-1 borehole (unknown depth); b Peterd-1 borehole (collection of the Mecsek Ore Mining Company, thin section No. 95); c Szava-1 borehole (depth: 444.8 m); d Szalánta-3 borehole (depth: $381.0 \mathrm{~m}$ ); e Egerág-7 borehole (depth: $700 \mathrm{~m}$ ); f Egerág-7 borehole (depth: 1200 m). c-f samples derive from the collection of the Eötvös Loránd University, Budapest (photo: Jakab 2005). $L$ lithic clast, $f_{s p}$ feldspar, $q z$ quartz. Altered pumices are highlighted by yellow dashed lines. .148

Supplementary Figure II.5 Accessory minerals in the samples of the outcrop of the Gyürüfü Rhyolite, Western Mecsek Mts (BSE images). a Euhedral, zoned zircon, broken at one of the pyramids; $\mathbf{b}$ and $\mathbf{c}$ Euhedral apatite crystals with rounded, resorbed cores; $\mathbf{d}$ Rounded opaque mineral (ilmenite according to the composition); e Idiomorhpic, partially resorbed monazite; $\mathbf{f}$ Rutile inclusion in an opaque pseudomorph after biotite .149

Supplementary Figure II.6 Accessory minerals in the samples of the Gyürüfü Rhyolite Formation, northern foreland of the Villány Mts. a Euhedral zircon as an inclusion in biotite, Vókány-2 borehole (unknown depth); b Euhedral, zoned zircon in the groundmass, Szalánta-3 borehole (depth: $333.3 \mathrm{~m}$ ); c Fragmented garnet crystals, Egerág-7 borehole (depth: $700 \mathrm{~m}$ ); d Subhedral garnet, Egerág-7 borehole (depth: $~ 700 \mathrm{~m}$ ); e Subhedral, chloritized, fragmented garnet showing intergrowth with K-feldspar, Szalánta-3 borehole (depth: $387.5 \mathrm{~m}$ ); f Fragmented garnet in K-feldspar as inclusion, Szalánta-3 borehole (depth: $404.8 \mathrm{~m}$ ). bt biotite, $c h l$ chlorite, $f s p$ feldspar, grt garnet, $z r n$ zircon, $1 N$ plane polarized light, $+N$ crossed polars.

Supplementary Figure IV.1 Post-magmatic alterations of the Permian felsic volcanic rocks. a-b Sample Peterd-1, pyroclastite (northern foreland of the Villány Mts, borehole): pectinate K-feldspar phenocrysts; c-d Sample Kelebia-7, pyroclastite (Kelebia area, borehole, low-grade metamorphic rock): c Strongly altered, sericitized, parallel pumices, creating well-defined foliation; $\mathbf{d}$ Quartz phenocryst with symmetric K-mica overgrowth in pressure shadow paralell with the foliation; e-f Sample Szava-1, lava (northern foreland of the Villány Mts, borehole): clots containing zircon, apatite, opaque minerals, carbonate and muscovite (hydrothermal mineralization). $a p$ apatite, $b t$ biotite, $c b$ carbonate, $f s p$ feldspar, $m s$ muscovite, $o p q$ opaque mineral, $p$ altered pumice, $p x$ pseudomorph after pyroxene, $q$ quartz, zrn zircon, $P P L$ plane polarized light, $X P L$ crossed polars. 


\section{LIST OF SUPPLEMENTARY TABLES}

Supplementary Table II.1 Summarizing table of the available and studied samples (thin sections) of the Gyürüfü Rhyolite Formation at the northern foreland of the Villány Mts....

Supplementary Table II.2 The major lithological groups (pyroclastites and lavas) of the Gyürüfü Rhyolite in the area of Southern Transdanubia....

Supplementary Table IV.1 Major and trace elements data of the Permian volcanic rocks of the Tisza Mega-unit, Hungary (Western Mecsek Mts, northern foreland of the Villány Mts). $p$ pyroclastic rocks, $l$ lavas, $\mathrm{Eu} / \mathrm{Eu}^{*}=\left[\mathrm{Eu}_{\mathrm{N}} /\left(\mathrm{Sm}_{\mathrm{N}} \times \mathrm{Gd}_{\mathrm{N}}\right)^{1 / 2}\right], N=$ chondrite normalized values. Chondrite data come from Sun and McDonough (1989).

Supplementary Table IV.2 Major and trace elements data of the Permian volcanic rocks of the Tisza Mega-unit, Hungary (Máriakéménd-Báta Basement Range, Battonya-Pusztaföldvár Basement Ridge, Kelebia area). Bat Battonya; $p$ pyroclastic rocks, $l$ lavas, $\mathrm{Eu} / \mathrm{Eu}^{*}=\left[\mathrm{Eu}_{\mathrm{N}} /\left(\mathrm{Sm}_{\mathrm{N}} \times \mathrm{Gd}_{\mathrm{N}}\right)^{1 / 2}\right], N=$ chondrite normalized values. Chondrite data come from Sun and McDonough (1989)

Supplementary Table IV.3 Major and trace elements data of the Permian volcanic rocks of the ALCAPA Mega-unit (Central Transdanubia, Hungary). $d$ dykes; $l$ lavas; Eu/Eu* $=\left[\mathrm{Eu}_{\mathrm{N}} /\left(\mathrm{Sm}_{\mathrm{N}} \times \mathrm{Gd}_{\mathrm{N}}\right)^{1 / 2}\right], N=$ chondrite normalized values. Chondrite data come from Sun and McDonough (1989).... 


\section{CHAPTER I}

\section{Introduction}

\subsection{Late Palaeozoic volcanism in the Carpathian-Pannonian region, Central Europe: Where and when did it occur?}

During the Permo-Carboniferous times several large-volume magmatic events occurred along the European Variscan Orogenic Belt controlled by a post-collisional to extensional tectonic environment (Cortesogno et al. 1998; Awdankiewicz 1999; Wilson et al. 2004; Paulick and Breitkreuz 2005; Vozárová et al. 2009, 2015, 2016; Seghedi 2010; Wilcock et al. 2013; Letsch et al. 2014; Nicolae et al. 2014; Repstock et al. 2017; Ondrejka et al. 2018). The most primitive products of the Late Palaeozoic, often bimodal (basalticdacitic/rhyolitic) magmatism are mantle-derived mafic lavas dominantly present in Northern Europe; however, shallow-level processes in the crust (e.g., magmatic differentiation, anatexis and assimilation-fractional crystallization) resulted in more evolved felsic plutonic and volcanic rocks that are widespread in Europe (Wilson et al. 2004). Zircon U-Pb geochronology of the felsic volcanites revealed a dominant Latest Carboniferous-Early Permian ( 300-280 Ma) volcanic eposide in the Central European Variscides (e.g., South Permian and Intra-Sudetic Basins, Eastern Germany and SW Poland, respectively); however, younger, Mid-Permian or Late Permian-Earliest Triassic ages (up to $\sim 251 \mathrm{Ma}$ ) were obtained as well, suggesting a long-lasting magmatic activity (Wilson et al. 2004; Paulick and Breitkreuz 2005; Vozárová et al. 2009, 2015, 2016; Ondrejka et al. 2018; Słodczyk et al. 2018).

Permian volcanic activity was recognized in several parts of the CarpathianPannonian region (e.g., Lelkes-Felvári and Klötzli 2004; Haas et al. 2008; Vozárová et al. 2009, 2015, 2016; Ondrejka et al. 2018). Both terranes in the basement of the Pannonian Basin, the ALCAPA Mega-unit (ALCAPA MU), showing southern-Alpine affinity and the European-derived Tisza Mega-unit (Tisza MU) bear the signs of PermoCarboniferous magmatism (Fig. I.1); however, there is limited petrographic, geochemical or geochronolgical information about it.

In the area of the ALCAPA MU, Late Palaeozoic felsic volcanic rocks are prevalent within the intramontane siliciclastic sequences of the Western Carpathians (Fig. I.1), including most of its crustal-scale superunits (e.g., Northern and Southern Gemeric Units, Northern Veporic Unit, Silicic Unit). Zircon U-Pb ages of the dacitic/rhyolitic 
rocks vary between $279.0 \pm 4.4 \mathrm{Ma}$ almost continually up to $251.4 \pm 3.5 \mathrm{Ma}$, suggesting multiple distinct volcanic episodes (Vozárová et al. 2009, 2015, 2016; Ondrejka et al. 2018). In Central Transdanubia (Hungary), Permian felsic volcanic rocks occur as well, e.g., in the boreholes of the Balaton Highland (e.g., Kékkút-4; Fülöp 1990) and as dykes within the crystalline limestone quarry near Polgárdi (Fig. I.1). Zircon U-Pb ages of these lavas/dykes (known as Kékkút Dacite or "Kékkút quartz-porphyry" in the Hungarian lithostratigraphic literatures) point to a Lower Permian volcanic epoch in this area (291.4 土4.7 Ma; Lelkes-Felvári and Klötzli 2004).

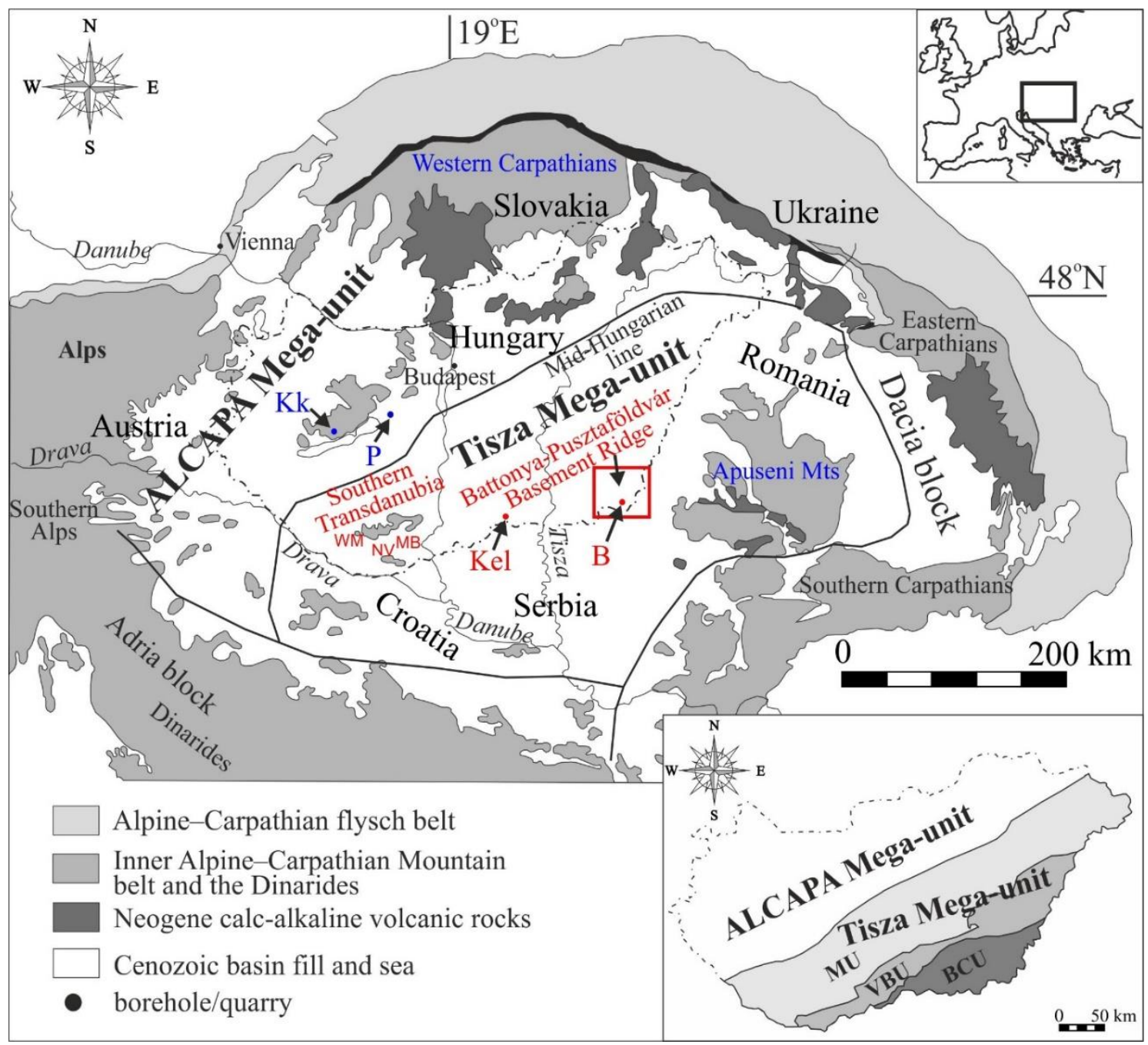

Figure I.1 Distribution of the Permian felsic volcanic rocks in the Carpathian-Pannonian region, pointing out the occurrences of the Gyürüfü Rhyolite Formation (red) studied in the $\mathrm{PhD}$ research and the analogous formations of the region that were compared to them (blue). Index map (below) shows the Alpine facies zones in the basement of the Tisza Mega-unit. B Battonya, Kel Kelebia, Kk Kékkút-4 well, $M B$ Máriakéménd-Báta Basement Range, $N V$ northern foreland of the Villány Mts, $P$ Polgárdi quarry, $W M$ Western Mecsek Mts, $M U$ Mecsek Unit, VBU Villány-Bihor Unit, $B C U$ Békés-Codru Unit

In the Tisza MU, Permian felsic volcanic rocks (rhyolitic ignimbrites) occur in the central-western part of the Apuseni Mts, Romania (Codru and Biharia Nappe Systems; Fig. I.1) where they are associated with mafic-intermediate lavas (basalt and subordinate 
andesite) representing a bimodal volcanic suite (Nicolae et al. 2014). In the Hungarian part of the mega-unit, Permian felsic volcanites are well-known in Southern Transdanubia (outcrop, boreholes and gravel material) and in the eastern Pannonian Basin (e.g., Battonya and Kelebia areas, boreholes) and collectively named Gyürüfü Rhyolite Formation (Fülöp 1994; Császár 2005; Fig. I.1). The doctoral thesis focuses on the latter, including almost all of its available drill cores and outcrop rock samples in order to fulfill a complex (petrographic, geochemical and geochronological) study in the light of modern volcanological views. Moreover, the studied rocks were placed in a regional framework (as part of a correlational study), among the aforementioned formations of the Carpathian-Pannonian region.

\subsection{The Gyürüfü Rhyolite Formation: Why has it been important to be (re)examined?}

The Gyürüfü Rhyolite Formation is the only volcanic rock assemblage within the thick Permo-Carboniferous intramontane molasse sequence of the Tisza MU (Fülöp 1994; Császár 2005). Permian felsic volcanic rocks, classified into this formation, occur in the basement of S Transdanubia and the eastern Pannonian Basin, representing all the three Alpine facies zones of the mega-unit (the Mecsek, the Villány-Bihor and the BékésCodru Units; Szederkényi et al. 2013); however, the only outcrop localities of the formation is in the area of Gyürüfü, Western Mecsek Mts (Fig. I.1; Szederkényi 1962; Barabásné Stuhl 1988). Recognition of such rocks was associated with the previous uranium ore (S Transdanubia) and hydrocarbon exploration works (eastern Pannonian Basin) of the second half of the 20th century (e.g., Szederkényi 1962; Szepesházy 1967; Fazekas 1978; Barabásné Stuhl 1988; Kőrössy 2005a,b) that interpreted most of them as lavas ('quartz-porphyry'). Archive drilling reports outlined the main regions where the Gyürüfü Rhyolite is present, including (1) the Western Mecsek Mts as part of the Mecsek Unit; (2) the Máriakéménd-Báta Basement Range (Máriakéménd-Báta BR) and (3) the northern foreland of the Villány Mts as parts of the Villány-Bihor Unit; and (4) the Battonya-Pusztaföldvár Basement Ridge (Battonya-Pusztaföldvár BR) as well as (5) the Kelebia area belonging to the Békés-Codru Unit (Fig. I.1).

Despite the traditional interpretations that considered rhyolitic lava flows in the drillings and in the outcrop, recent studies focusing on the drill cores and the pebbles of a Miocene conglomerate formation representing Permian magmatic rocks from the 
Western Mecsek Mts, S Transdanubia (e.g., Varga 2009; Hidasi et al. 2015), suggested their pyroclastic origin. The latter drew attention to the necessity of reconsideration of the previous reports. On the other hand, the previous $\mathrm{K}-\mathrm{Ar}$ age data of these rocks were dominantly Triassic (Balogh and Kovách 1973) which contradicts their stratigraphic position. The Gyürüfü Rhyolite is supposed to form a Lower Permian marker horizon, playing an important role among the Permo-Carboniferous sedimentary formations. Therefore, reliable zircon $\mathrm{U}-\mathrm{Pb}$ ages were crucial to be obtained as well as investigating its marker horizon role in the Permian stratigraphy. Geochemical characterization and petrogenetic interpretations of the rocks were also incomplete, therefore I focused on these aspects, as well.

\subsection{Altered volcanic rocks: How to start dealing with them?}

When it comes to the petrographic or geochemical observation of Palaeozoic volcanites we should take into consideration that these ancient rocks might have undergone various syn- and post-volcanic alterations (tectonic deformation, K-metasomatism, albitization, hydrothermal alteration, metamorphism etc.). Primary textural features could have been overprinted or modified, making the genetic interpretation (e.g., pyroclastite, lava or dyke) of such samples a difficult task for volcanologists (e.g., Allen 1988; Branney and Kokelaar 1992; Branney et al. 1992; Henry and Wolff 1992; Gifkins et al. 2005a,b; Paulick and Breitkreuz 2005). The incomplete destruction of primary textures and the different alteration styles can result in the development of false textures or pseudotextures, as well. Thus, false pyroclastic textures (false shards, false eutaxitic texture) as well as false massive textures can be formed, usually causing significant difficulties in the reliable interpretation of ancient volcanic rocks (Allen 1988; Gifkins et al. 2005a,b). In the studied areas, boreholes as pointwise sources of information, that could be situated several $\mathrm{km}$ far from each other, restrict the possibility of exploring wellvisible volcanic edifices such as the limited amount of available drill cores. Therefore, the accurate petrographic observations and facies analyses of the studied samples were crucial in the understanding of volcanic processes; however, the entire reconstruction would most possibly never be completed in the studied areas.

The geochemical composition of these ancient rocks might have been altered, as well. K-metasomatism or albitization are general features of the Permian felsic volcanic rocks in the European Variscides (Awdankiewicz 1999; Paulick and Breitkreuz 2005; 
Vozárová et al. 2015, 2016). Therefore, the major element composition of the studied rocks should be used carefully when it comes to obtaining petrogenetic information. However, immobile trace elements are more useful for the latter, being less affected by secondary alterations. As K-metasomatism is one of the most significant alteration processes, previous $\mathrm{K}-\mathrm{Ar}$ age determinations of such rocks are dominantly not reliable.

The terminology used in the petrographic descriptions and interpretations are derived from the following principal references: Branney and Kokelaar (1992), Branney et al. (1992), Henry and Wolff (1992), McPhie et al. (1993), Branney and Kokelaar (2002), Gifkins et al. (2005a,b), Paulick and Breitkreuz (2005), Brown et al. (2012) and Breitkreuz (2013). The most important terms used in the petrographic descriptions and interpretations are summarized in Table I.1.

Table I.1 Table of the most significant terms used in the petrographic descriptions and interpretations, explaining their meaning. Some references are given by each expression

\begin{tabular}{|c|c|c|}
\hline Term & Meaning & References (examples) \\
\hline Axiolite & $\begin{array}{l}\text { Product of high-temperature devitrification of silicic } \\
\text { glass. Spherulitic aggregate arranged at right angles to } \\
\text { central axis rather than from a point }\end{array}$ & Gifkins et al. (2005b) \\
\hline Coated particles & $\begin{array}{l}\text { Fragile aggregates comprised of a crystal, crystal } \\
\text { fragment, pumice or lithic clast partially covered in fine } \\
\text { ash particles }\end{array}$ & Brown et al. (2012) \\
\hline $\begin{array}{l}\text { Eutaxitic } \\
\text { texture }\end{array}$ & $\begin{array}{l}\text { Pre-tectonic foliation defined by the parallel alignment of } \\
\text { fiammes }\end{array}$ & Gifkins et al. $(2005 a, b)$ \\
\hline Felsitic texture & $\begin{array}{l}\text { Igneous texture comprised of a very fine-grained } \\
\text { groundmass of mosaic quartz and alkali feldspar crystals }\end{array}$ & $\begin{array}{l}\text { MacKenzie et al. } \\
\text { (1982) }\end{array}$ \\
\hline Fiamme & $\begin{array}{l}\text { Flame-like, glassy or devitrified lenses, which define a } \\
\text { pre-tectonic foliaton }\end{array}$ & Gifkins et al. (2005a,b) \\
\hline $\begin{array}{l}\text { Granophyric } \\
\text { texture }\end{array}$ & $\begin{array}{l}\text { Common recrystallization texture of igneous rocks } \\
\text { comprised of an intergrowth of quartz and alkali feldspar }\end{array}$ & Gifkins et al. (2005b) \\
\hline Lava-like & $\begin{array}{l}\text { Extremely high-grade (intensely welded) ignimbrite } \\
\text { lithofacies that is texturally indistinguishable from lava }\end{array}$ & $\begin{array}{l}\text { Branney et al. (1992); } \\
\text { Branney and Kokelaar } \\
(1992)\end{array}$ \\
\hline Perlitic cracks & $\begin{array}{l}\text { A network of fine typically concentric, arcuate fractures } \\
\text { that enclose glassy or originally glassy cores }\end{array}$ & Gifkins et al. (2005b) \\
\hline Rheomorphic & $\begin{array}{l}\text { Any non-particulate flow structure that formed prior to } \\
\text { lithification }\end{array}$ & $\begin{array}{l}\text { Branney et al. (1992); } \\
\text { Branney and Kokelaar } \\
(1992)\end{array}$ \\
\hline Spherulite & $\begin{array}{l}\text { Product of high-temperature devitrification of silicic } \\
\text { glass. Radiating aggregates or bundles of acicular and } \\
\text { fibrous cystals }\end{array}$ & $\begin{array}{l}\text { Lofgren (1971); } \\
\text { Gifkins et al. (2005b); } \\
\text { Breitkreuz (2013) }\end{array}$ \\
\hline $\begin{array}{l}\text { Vitroclastic } \\
\text { texture }\end{array}$ & $\begin{array}{l}\text { Pyroclastic texture that is composed of glass fragments } \\
\text { cemented by glass }\end{array}$ & $\begin{array}{l}\text { Branney et al. (1992); } \\
\text { Branney and Kokelaar } \\
\text { (1992) }\end{array}$ \\
\hline $\begin{array}{l}\text { Vitrophyric } \\
\text { texture }\end{array}$ & $\begin{array}{l}\text { Inequigranular volcanic texture in which larger crystals } \\
\text { (porphyres) are embedded in glassy groundmass }\end{array}$ & Gifkins et al. (2005b) \\
\hline
\end{tabular}

\subsection{Aims and the structure of the dissertation: What kind of methods were applied and how were they documented?}


The major goal of the PhD research was the complex (petrographic, geochemical and geochronological) study of the Gyürüfü Rhyolite Formation, including almost all the available drill cores and outcrop rock samples.

Petrographic observations were carried out on drill cores and archive thin sections associated with the previous uranium ore and hydrocarbon exploration; however, new samples were prepared for this study, too. The analyses were performed at the Department of Mineralogy, Geochemistry and Petrology, University of Szeged using Brunel SP-300$\mathrm{P}$ and Olympus BX41 polarizing microscopes. As part of the petrography, archive descriptions and interpretations were checked, and reinterpreted if it was necessary. Altered volcanic rocks were examined carefully and their feasible volcanic facies were defined in the light of modern volcanological views. The detailed petrography of the samples of S Transdanubia was published as two articles in Földtani Közlöny (in Hungarian). These two studies were contracted and translated into English and presented in this thesis as Chapter II. Detailed petrography of the Permian felsic volcanic rocks in SE Hungary (focusing on the Battonya-Pusztaföldvár BR) was published in Central European Geology (CEG) and occurs in the thesis as Chapter III. Further petrographic results were also published in the most complex, fourth article associated with the $\mathrm{PhD}$ research (Chapter IV), in International Journal of Earth Sciences (IJES), including the Máriakéménd-Báta BR and the Kelebia area, that were not documented in the aforementioned petrographic studies.

A total of 18 samples representing the Gyürüfü Rhyolite Formation were selected for whole-rock geochemistry. These specimens were powdered and analyzed at the Bureau Veritas Mineral Laboratories (AcmeLabs, Vancouver, Canada) by ICP-ES (major elements) and ICP-MS (trace elements including rare earth elements). Geochemical results of the Gyürüfü Rhyolite were published in IJES and can be found in the dissertation in Chapter IV.

As part of the $\mathrm{PhD}$ research zircon crystals were separated from five distinct materials of the Gyürüfü Rhyolite, including samples of S Transdanubia and the eastern Pannonian Basin. Standard heavy mineral separation (crusing, sieving, heavy liquid separation, magnetic separation and hand-picking), sample (crystal mount) preparation were done by myself at the Department of Petrology and Geochemistry, Eötvös Loránd University, Budapest as well as the cathodoluminscence mapping (with the assistance of Zsolt Bendő). In situ U-Pb radiometric age determinations were performed at the ETH Zürich, Switzerland and the GÖochron Laboratories of Georg-August University, 
Göttingen, Germany by Réka Lukács and István Dunkl, respectively, using LA-SF-ICPMS. Zircon U-Pb radiometric ages of the Gyürüfü Rhyolite Formation were published in IJES (Chapter IV).

Petrographic, geochemical and geochronological results were used in order to correlate the Permian felsic volcanites of the Gyürüfü Rhyolite Formation with the analogous formations in the Carpathian-Pannonian region. These results were published in CEG and IJES (Chapters III and IV, respectively). They were also completed with the preliminary results of the ongoing research of the Permian felsic volcanic rocks in the Apuseni Mts, and further information could be found in the Conclusions (Outlook, Chapter V).

In the Conclusions (Chapter V), all the new results are summarized related to the main areas of the Gyürüfü Rhyolite Formation (S Transdanubia and the eastern Pannonian Basin) and integrated at larger scales (Carpathian-Pannonian region, Tisza Mega-unit), as well.

As the three distinct journals (CEG, IJES, Földtani Közlöny) use different format, in order to make a uniform style in the $\mathrm{PhD}$ Thesis (e.g., grammar, citations, figures and tables), generally the format of International Journal of Earth Sciences was preferred and followed. 


\title{
CHAPTER II
}

\section{PETROGRAPHY OF THE GYÜRÜFÜ RHYOLITE FORMATION, SOUTHERN TRANSDANUBIA, HUNGARY}

This chapter includes the results of the $\mathrm{PhD}$ research associated with the area of Southern Transdanubia, published as two articles in Földtani Közlöny (in Hungarian), namely:

\section{PETROGRAPHY OF THE GYÜRÜFÜ RHYOLITE FORMATION, WESTERN MECSEK MTS, HUNGARY}

Földtani Közlöny

146/4, 335-354 (2016)

and

\section{PETROGRAPHY OF THE GYÜRÜFÜ RHYOLITE FORMATION, NORTHERN FORELAND OF THE VILLÁNY MTS, HUNGARY}

\author{
Földtani Közlöny \\ 147/4, 357-382 (2017)
}

DOI 10.23928/foldt.kozl.2017.147.4.357

\begin{abstract}
Máté Szemerédi
Department of Mineralogy, Geochemistry and Petrology, 'Vulcano' Petrology and Geochemistry Research Group, University of Szeged, Szeged, Hungary; MTA-ELTE Volcanology Research Group, Budapest, Hungary email: h462582@stud.u-szeged.hu; szemeredi.mate@gmail.com

\section{Andrea Varga}

Department of Mineralogy, Geochemistry and Petrology, 'Vulcano' Petrology and Geochemistry Research Group, University of Szeged, Szeged, Hungary email: raucsikvarga@geo.u-szeged.hu
\end{abstract}

\section{Réka Lukács}

MTA-ELTE Volcanology Research Group, Budapest, Hungary; Department of Mineralogy, Geochemistry and Petrology, 'Vulcano' Petrology and Geochemistry Research Group, University of Szeged, Szeged, Hungary email: reka.harangi@gmail.com

\section{Elemér Pál-Molnár}

Department of Mineralogy, Geochemistry and Petrology, 'Vulcano' Petrology and Geochemistry Research Group, University of Szeged, Szeged, Hungary; MTA-ELTE Volcanology Research Group,

Budapest, Hungary email: palm@geo.u-szeged.hu 


\title{
Petrography of the Gyürüfü Rhyolite Formation, Southern Transdanubia,
} Hungary

\author{
by: Máté Szemerédi, Andrea Varga, Réka Lukács and Elemér Pál-Molnár
}

\subsection{Introduction, previous results}

The Permo-Carboniferous sequence in Southern Transdanubia dominantly consists of intramontane molasse sedimentary rocks (fluvial/alluvial conglomerates, sandstones, siltstones and claystones) of great thickness that are derived from the erosion of the Variscan basement formations. According to the traditional lithostratigraphy, the Lower Permian Gyürüfü Rhyolite Formation is the only Late Palaeozoic volcanic rock assemblage in this area. The Gyürüfü Rhyolite is represented by a single outrop in the Western Mecsek Mts (Fig. II.1 and Supplementary Figure II.1); however, it is also wellknown by uranium ore exploration boreholes in S Transdanubia (Fig. II.1) as well as the gravel material of the younger siliciclastic formations (e.g., the Miocene Szászvár Formation; Szederkényi 1962; Barabásné Stuhl 1988; Fülöp 1994).

Recognition of the Permian felsic volcanic rocks was associated with the uranium ore exploration work during the second half of the 20th century. Previous studies (e.g., Szederkényi 1962; Barabásné Stuhl 1988; Fülöp 1994; Barabás and Barabásné Stuhl 1998) reported lavas from the outcrop of the Gyürüfü Rhyolite, in contrast to their possible pyroclastic (ignimbrite) origin mentioned by Pantó (in Boczán et al. 1966). The latter was also supported by Hidasi et al. (2015) due to the identification of flattened, oriented, devitrified pumices in the drill cores and the gravel material of the Western Mecsek Mts, drawing attention to the importance of the reconsideration of archive reports. Besides the Western Mecsek Mts, previous papers and drilling reports (Fazekas 1978; Barabásné Stuhl 1988; Császár 2005) outlined two more (subsurface) regions of the Permian felsic volcanic rocks in S Transdanubia that are the northern foreland of the Villány Mts and the Máriakéménd-Báta Basement Range (Fig. II.1). In contrast to the Western Mecsek Mts, at the northern foreland of the Villány Mts, not only lavas, but also several felsic volcanic rock varieties were mentioned (e.g., boreholes Bisse-1: pyroclastic rocks and lavas, Peterd-1: lavas, Szava-1: subvolcanic rocks/dykes as 'microgranite porphyry', Vókány-2: volcanic vent facies, Egerág-7: lavas with subordinate tuff/agglomerate intercalations and Szalánta-3: lavas with pyroclastite intercalations; Kassai 1976; Fazekas 1978; Konrád 1981; Barabásné Stuhl 1988; Fazekas and Vincze 1991). In this chapter, outcrop rock samples in the Western Mecsek Mts and all available 
drill cores and thin sections representing the Gyürüfü Rhyolite Formation at the northern foreland of the Villány Mts as well as the archive descriptions and interpretations were reexamined in the light of modern volcanological views.

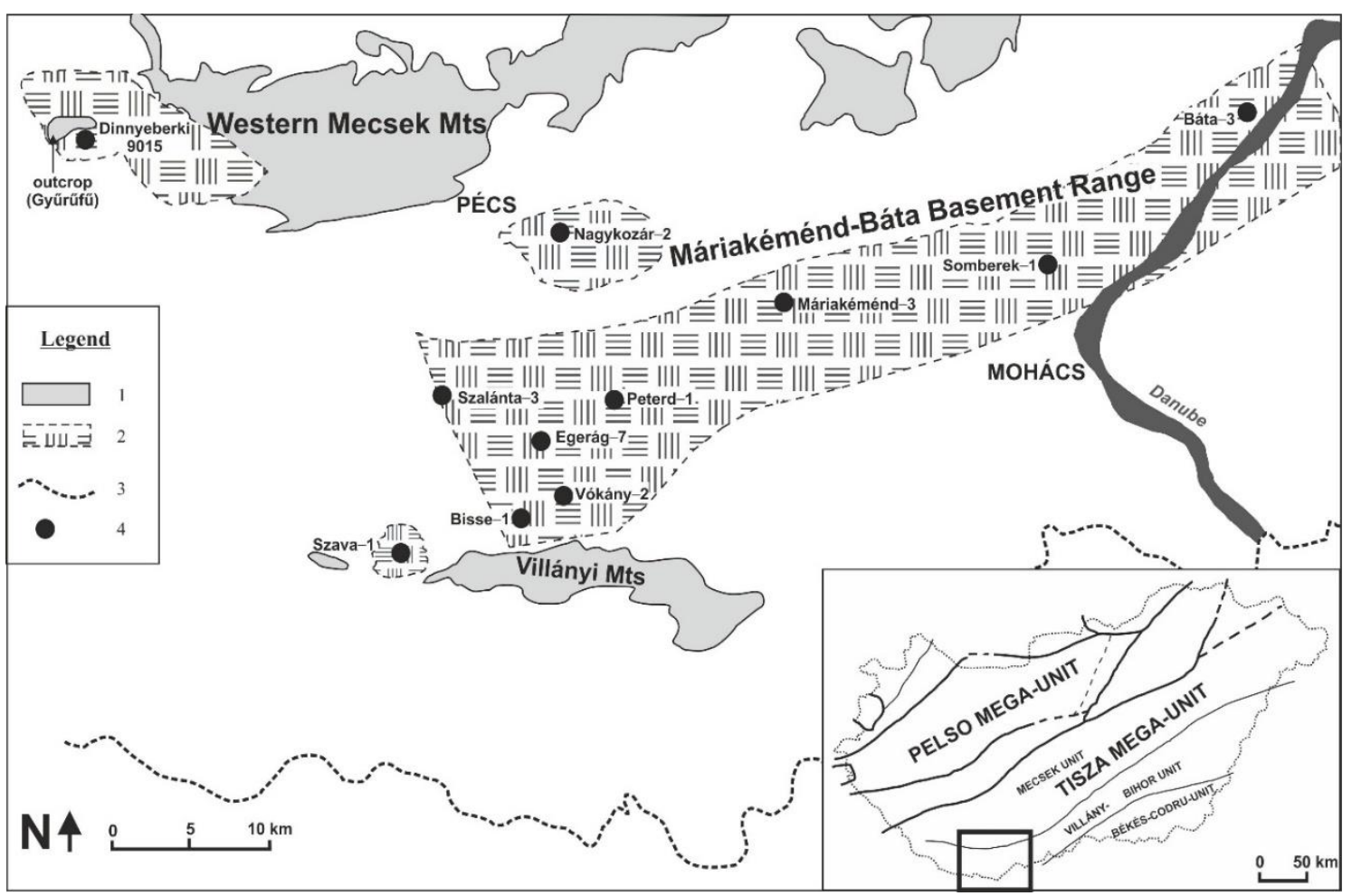

Figure II.1. Regional distribution of the Gyürüfü Rhyolite Formation in Southern Transdanubia, displaying the most significant boreholes that explored the formation (based on Barabásné Stuhl 1988). 1 hills/moutains, 2 the subsurface distribution of the Gyürüfü Rhyolite Formation, 3 frontier, 4 borehole

\subsection{Geological background}

The Gyürüfü Rhyolite is the only volcanic rock assemblage within the thick PermoCarboniferous siliciclastic sequence in S Transdanubia. Traditionallly, all the Permian felsic volcanic rocks in the broader area of the Tisza Mega-unit (Hungary) were classified into this formation in the lithostratigraphic literatures, and supposed to belong to an Early Permian rift-related felsic volcanism (Fülöp 1994; Császár 2005). The Gyürüfü Rhyolite is thought to be the youngest member of an Upper Carboniferous-Lower Permian sedimentary sequence (Barabásné Stuhl 1988) that consists of the following older, sedimentary formations: the Upper Carboniferous Téseny Metasandstone (Varga et al. 2012), the Lower Permian (?) Túrony Formation (Varga and Raucsik 2009) and the Lower Permian Korpád Sandstone Formation. The younger Middle to Late Permian siliciclastic sequence consists of the Cserdi Conglomerate, the Boda Claystone (Máthé 
and Varga 2012) and the Kővágószőlős Sandstone Formations (Barabásné Stuhl 1988; Fülöp 1994; Barabás and Barabásné Stuhl 1998).

The Gyürüfü Rhyolite has a single outcrop in the Western Mecsek Mts (between the villages of Gyürüfü and Dinnyeberki; Fig. II.1 and Supplementary Figure II.1); however, the formation is well-known by the uranium ore ( $\mathrm{S}$ Transdanubia) and hydrocarbon (eastern Pannonian Basin) exploration boreholes, including all the three Mesozoic facies zones of the Tisza Mega-unit (Mecsek, Villány-Bihor and Békés-Codru Units; Szederkényi et al. 2013; Fig. II.1). The wells outlined five major subsurface regions of the Permian felsic volcanic rocks, namely (1) the Western Mecsek Mts, (2) the northern foreland of the Villány Mts, (3) the Máriakéménd-Báta Basement Range, (4) the Kelebia area and (5) the Battonya-Pusztaföldvár Basement Ridge; three of which are situated in S Transdanubia (Fig, II.1; Barasbásné Stuhl 1988; Fülöp 1994; Császár 2005). The most important information (top, base, minimum thickness) about the boreholes of the latter areas are summarized in Table II.1.

In the Western Mecsek Mts, Permian felsic volcanic rocks were encountered in several boreholes near the village of Gyürüfü, including boreholes Gyürüfü 9007, 9008, 9012, Dinnyeberki 9015 and 9018. In the Western Mecsek Anticline, the Gyürüfü Rhyolite was only penetrated by the exploration borehole No. XV (Szederkényi 1962; Barabásné Stuhl 1988; Fülöp 1994; Barabás and Barabásné Stuhl 1998). Between the Mecsek and the Villány Mts several boreholes penetrated Permian felsic volcanic rocks (Fig. II.1). The Bisse-1, the Peterd-1, the Vókány-2, the Szava-1, the Egerág-7 and the Szalánta-3 wells outlined the northern foreland of the Villány Mts as another major subsurface region; while the area pointed out by the Nagykozár-2, the Máriakéménd-3, the Somberek-1 and the Báta-3 boreholes was separated as the Máriakéménd-Báta Basement Range (Barabásné Stuhl 1988). The gravel material of the Gyürüfü Rhyolite could be found in the younger sedimentary formations of the region, as well. One of them is the Miocene conglomerate (Szászvár Formation) that contains 35-40\% Permian volcanite pebbles in the area of the Western Mecsek Mts (Józsa et al. 2009).

The Gyürüfü Rhyolite is stratigraphically underlain by the Korpád Sandstone Formation, that was not always penetrated by the exploration boreholes, especially at the northern foreland of the Villány Mts where the Permian volcanic rocks show much greater thickness than in case of the other subsurface regions (Table II.1). The stratigraphic top is the Cserdi Conglomerate, present dominantly in the Western Mecsek Mts and the Máriakéménd-Báta Basement Range. The latter was eroded at the northern foreland of 
the Villány Mts where the Gyürüfü Rhyolite is covered by the Lower Triassic Jakabhegy Sandstone or younger Pannonian sediments (Table II.1). The greatest minimum thickness of the Gyürüfü Rhyolite was measured at the northern foreland of the Villány Mts (e.g., Bisse-1: 447 m, Vókány-2: $461 \mathrm{~m}$ and Egerág-7: $831 \mathrm{~m}$ ), while its maximum thickness in the other regions is not higher than 100-150 m (Table II.1).

Table II.1. A summarizing table of boreholes (subsurface region, base, top, minimum thickness), exploring the Gyürüfü Rhyolite Formation in the area of Southern Transdanubia

\begin{tabular}{|c|c|c|c|c|}
\hline Subsurface region & Borehole & Base & Top & Thickness (m) \\
\hline \multirow{6}{*}{$\begin{array}{l}\text { Western Mecsek } \\
\text { Mts }\end{array}$} & Dinnyeberki 9015 & $\begin{array}{l}\text { Korpád Sandstone } \\
\text { (Lower Permian) }\end{array}$ & $\begin{array}{l}\text { Cserdi Formation } \\
\text { (Middle Permian) }\end{array}$ & 98.6 \\
\hline & $\begin{array}{l}\text { bell pit Gyürüfü } \\
701\end{array}$ & $\begin{array}{l}\text { Korpád Sandstone } \\
\text { (Lower Permian) }\end{array}$ & Pleistocene loess & 4.1 \\
\hline & Gyürüfü 9007 & not drilled & $\begin{array}{l}\text { Cserdi Formation } \\
\text { (Middle Permian) }\end{array}$ & $\geq 9.8$ \\
\hline & Gyürüfü 9008 & $\begin{array}{l}\text { Korpád Sandstone } \\
\text { (Lower Permian) }\end{array}$ & $\begin{array}{l}\text { Pannonian } \\
\text { sandstone }\end{array}$ & 18.4 \\
\hline & Gyürüfü 9012 & $\begin{array}{l}\text { Korpád Sandstone } \\
\text { (Lower Permian) }\end{array}$ & $\begin{array}{l}\text { Cserdi Formation } \\
\text { (Middle Permian) }\end{array}$ & 49.5 \\
\hline & $\begin{array}{l}\text { exploration } \\
\text { borehole No. XV }\end{array}$ & $\begin{array}{l}\text { Korpád Sandstone } \\
\text { (Lower Permian) }\end{array}$ & $\begin{array}{l}\text { Cserdi Formation } \\
\text { (Middle Permian) }\end{array}$ & 144.1 \\
\hline \multirow{6}{*}{$\begin{array}{l}\text { Northern foreland } \\
\text { of the Villány Mts }\end{array}$} & Bisse-1 & $\begin{array}{l}\text { Korpád Sandstone } \\
\text { (Lower Permian) }\end{array}$ & $\begin{array}{l}\text { Jakabhegy } \\
\text { Sandstone (Lower } \\
\text { Triassic) }\end{array}$ & 447.0 \\
\hline & Egerág-7 & not drilled & Pannonian & $\geq 831.0$ \\
\hline & Peterd-1 & not drilled & $\begin{array}{l}\text { Jakabhegy } \\
\text { Sandstone (Lower } \\
\text { Triassic) }\end{array}$ & $\geq 76.0$ \\
\hline & Szalánta-3 & not drilled & Pannonian & $\geq 316.2$ \\
\hline & Szava-1 & not drilled & $\begin{array}{l}\text { Carboniferous } \\
\text { (tectonic?) }\end{array}$ & $\geq 200.7$ \\
\hline & Vókány-2 & not drilled & $\begin{array}{l}\text { Jakabhegy } \\
\text { Sandstone (Lower } \\
\text { Triassic) }\end{array}$ & $\geq 461.0$ \\
\hline \multirow{4}{*}{$\begin{array}{l}\text { Máriakéménd- } \\
\text { Báta Basement } \\
\text { Range }\end{array}$} & Máriakéménd-3 & $\begin{array}{l}\text { Korpád Sandstone } \\
\text { (Lower Permian) }\end{array}$ & $\begin{array}{l}\text { Cserdi Formation } \\
\text { (Middle Permian) }\end{array}$ & 130.4 \\
\hline & Nagykozár-2 & $\begin{array}{l}\text { Korpád Sandstone } \\
\text { (Lower Permian) }\end{array}$ & $\begin{array}{l}\text { Cserdi Formation } \\
\text { (Middle Permian) }\end{array}$ & 52.4 \\
\hline & Somberek-1 & metamorphic & $\begin{array}{l}\text { Cserdi Formation } \\
\text { (Middle Permian) }\end{array}$ & 142.9 \\
\hline & Báta-3 & metamorphic & $\begin{array}{l}\text { Cserdi Formation } \\
\text { (Middle Permian) }\end{array}$ & 22.6 \\
\hline
\end{tabular}

\subsection{Sampling and analytical methods}

Fresh samples were collected in the Western Mecsek Mts from the outcrop of the Gyürüfü Rhyolite as well as its surroundings, including the roots of the nearby fallen trees and some detrital material (Supplementary Figures II.2 and II.3). The sampling locality in the 
Western Mecsek Mts is shown in Supplementary Figure II.1. As the drill cores of S Transdanubia were available in small amount, dominantly archive hand specimens and thin sections, associated with the previous uranium ore exploration work were used (Supplementary Figure II.4). These samples are derived from the following collections (see details in Supplementary Table I.1): (1) the collection of the Mecsek Ore Mining Company, (2) 'Volcanites, etalon collection' (composed by Via Fazekas), (3) the collections of the Department of Petrology and Geochemistry, Eötvös Loránd University, Budapest and (4) the Department of Mineralogy, Geochemistry and Petrology, University of Szeged, Szeged (some pieces of the latter donated by Mecsekérc Ltd., Pécs). Petrographic observations were done at the Department of Mineralogy, Geochemistry and Petrology, University of Szeged, using Brunel SP-300-P and Olympus BX41 polarizing microscopes. Modal compositions (vol\%) in the petrographic descriptions are estimations from thin sections. In addition, scanning electron microscope (SEM) analyses were also performed at University of Szeged (SEM Laboratory), using a Hitachi S-4700 field emission scanning electron microscope equipped with back-scattered (YAGBSE) and energy dispersive (EDS) detectors, at $20 \mathrm{kV}$ acceleration voltage (in vacuum) on polished thin sections.

\subsection{Results and interpretations}

In the followings, petrographic descriptions and interpretations are presented, including the outcrop rock samples in the Western Mecsek Mts as well as all available drill cores from the northern foreland of the Villány Mts. The summaries based on both macroscopic and microscopic observations are completed with representative photomicrographs for each area/borehole.

\subsubsection{Western Mecsek Mts}

\subsubsection{Outcrop}

\section{Description}

Felsic volcanic rocks (Supplementary Figures II.2 and II.3) consist of fine-grained, brownish or purplish grey groundmass, poorly-sorted phenocrysts and colourless clasts of various size that are dominantly flattened and oriented. In microscale, the orientation 

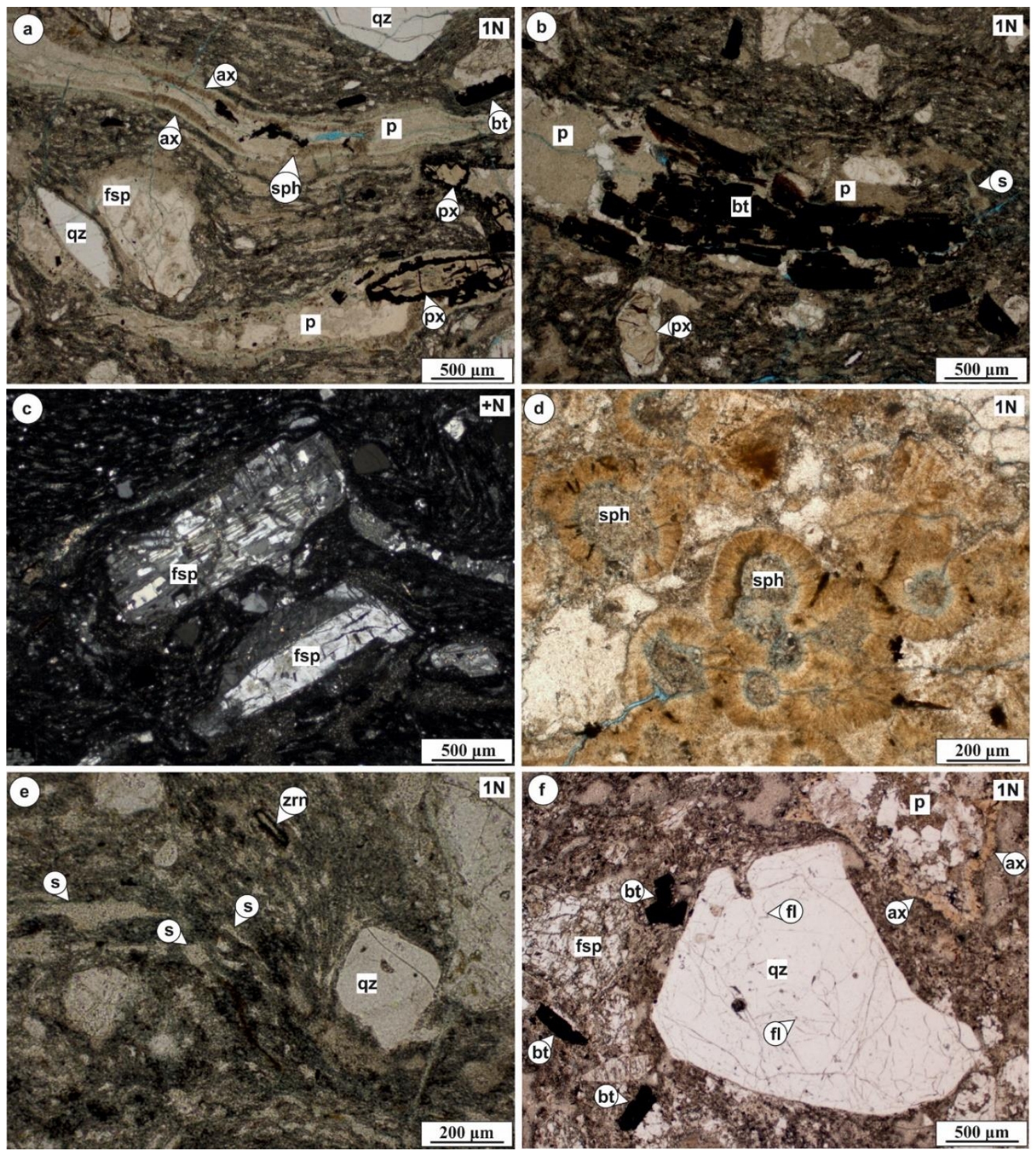

Figure II.2 Photomicrographs of the eutaxitic, welded, crystal-rich, pumice-bearing lapilli tuffs, Western

Mecsek Mts, outcrop. a Oriented pumices with axiolites at the rims and spherulites inside them, and opaque pseudomorphs after pyroxene; b Opaque pseudomorph after biotite inside an altered pumice; c Fragmented feldspar phenocrysts (plagioclase above, K-feldspar below); d Spherulites as high temperature crystallization domains; e Oriented, altered glass shards in the fine-grained groundmass; $\mathbf{f}$ Subhedral, resorbed quartz phenocryst and an altered, devitrified pumice. ax axiolite, $b t$ opaque pseudomorph after biotite, $f l$ fluid inclusion assemblages, $f s p$ feldspar, $p$ altered pumice, $p x$ opaque pseudomorph after pyroxene, $q z$ quartz, $s$ altered glass shard, $s p h$ spherulite, $z r n$ zircon, $1 N$ plane polarized light, $+N$ crossed polars

is borne by the irregular clasts and deformed, altered glass shards (juvenile components; Fig. II.2/a, c, e and Fig. II.3/d, e).

The size of the clasts varies from $\sim 3 \mathrm{~cm}$ (altered, devitrified pumices) to the average size of the altered glass shards $(100-300 \mu \mathrm{m})$; they are usually deformed, flattened and subrounded. Strong deformation of these components was observed around 
the phenocrysts. Axiolites are common at the altered pumice rims, while spherulites occur inside them (up to $\sim 300-400 \mu \mathrm{m}$; Fig. II.2/a, d). The inner part of the clasts is non-porous due to the compaction, partially filled with feldspar, quartz and biotite crystals (Fig. II.2/b), mosaic quartz in the former pores (Fig. II.2/d, f), fine-grained groundmass and opaque minerals. The former glass shards are dominantly oriented, deformed, forming a foliated texture with the devitrified pumices; however, some barely oriented samples bear relatively undeformed, $\mathrm{X}$ and $\mathrm{Y}$ shaped glass shards (Fig. II.3/e, f), as well. In case of the intensity of the orientation, siginificant differences were observed among the samples. It proved to be the most characteristic in the Gyürüfü (Istenkút; Supplementary Figure II.1) outcrop and barely prevalent in the detrital samples.

Rock-forming minerals are quartz, feldspar and opaque pseudomorphs after biotite and pyroxene, all of them showing no orientation. Quartz crystals (up to 2-3 mm; Fig. II.2/f and Fig. II.3/a) are subhedral, resorbed, often showing embayments and fluid inclusion assemblages inside them. Fragmented crystalloclasts $(\sim 100 \mu \mathrm{m})$ are common, too.

Feldspar crystals (up to $4-5 \mathrm{~mm}$; Fig. II.2/c and Fig. II.3/b, c) are subhedral or euhedral (tabular), fragmented. Around the fractures they are affected by alterations (e.g., argillitization, sericitization). Both K-feldspar showing Carlsbad twinning and polysynthetic twinned plagioclase occur; however; the former is 3-4 times more frequent. On the other hand, in many cases the domains of K-feldspar and plagioclase are present in single crystals at the same time, suggesting post-magmatic alteration.

Biotite crystals (up to $2 \mathrm{~mm}$; Fig. II.2/b, f and Fig. II.3/b, d, f) occur as opaque pseudomorphs (hematite) in most of the samples, relatively fresh crystals are rare. Their contribution to the rock-forming minerals is subordinate as well as in case of the strongly altered pyroxene crystals (up to $1-1.5 \mathrm{~mm}$; Fig. II.2/a, b and Fig. II.3/e). The latter are replaced by carbonate and/or sericite in the core and opaque minerals at the rims and along the fractures.

Accessory minerals identified in the samples were zircon (Fig. II.2/e; Supplementary Figure II.5/a), apatite (Supplementary Figure II.5/b, c), monazite (Supplementary Figure II.5/e), rutile (Supplementary Figure II.5/f), allanite (Fig. II.3/e) and xenotime. Based on SEM analyses, opaque minerals proved to be dominantly ilmenite (Supplementary Figure II.5/d). 
In some barely oriented samples, reddish brown fine-grained sedimentary lithic clasts (Fig. II.3/a) were found that most possibly represent the underlying Korpád Sandstone.
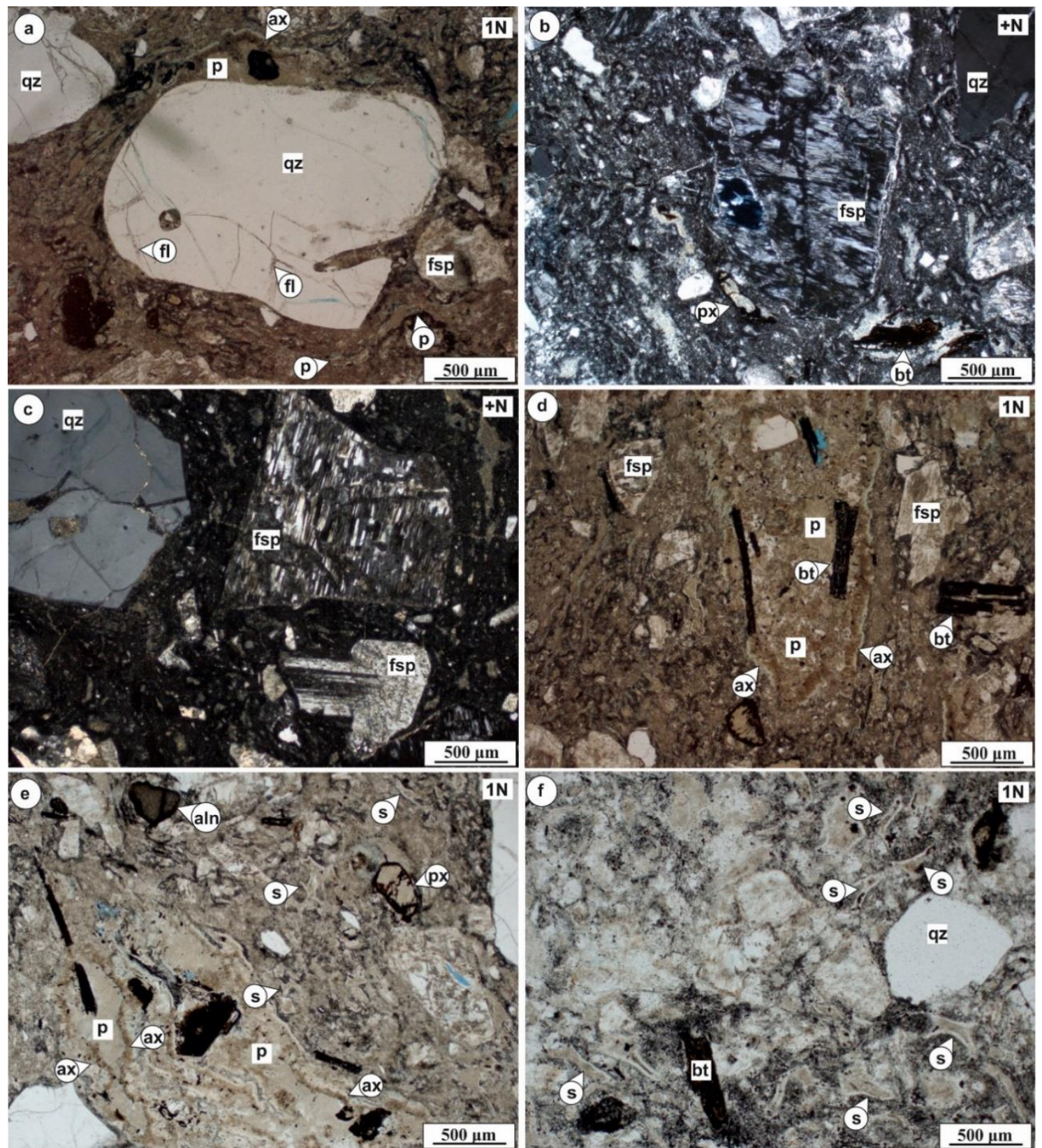

Figure II.3 Photomicrographs of the non-welded, crystal-rich, pumice-bearing lapilli tuffs, Western Mecsek Mts, outcrop. a Subhedral, resorbed quartz with fluid inclusion assemblages, axiolitic pumice, and a sedimentary lithic clast; b Subhedral, fragmented feldspar phenocryst; $\mathbf{c}$ Plagioclase (above) and Kfeldspar (below); d Altered pumice with axiolites at the rims and opaque pseudomorphs after biotite; $\mathbf{e}$ Poorly-oriented texture with altered pumices and glass shards; $\mathbf{f} X$ and $Y$ shaped glass shards in the matrix. aln allanite, $a x$ axiolite, $b t$ opaque pseudomorph after biotite, $f l$ fluid inclusion assemblages, $f_{s p}$ feldspar, $p$ altered pumice, $p x$ opaque pseudomorph after pyroxene, $q z$ quartz, $s$ altered glass shard, $1 N$ plane polarized light, $+N$ crossed polars

\section{Interpretation}

Despite lacking any bubble structure, the oriented clasts that occur in the samples are flattened, deformed, devitrified pumices. Some of them were strongly compacted due to 
the lithostatic pressure and their present form could be interpreted as a fiamme structure. Axiolites at the rims (Fig. II.2/a, f and Fig. II.3/d) and spherulites inside the devitrified pumices (Fig. II.2/a, d) point to high temperature crystallization (HTCDs: high temperature crystallization domains; Breitkreuz 2013). Oriented, coherent glass shards and pumices (e.g., Fig. II.2/a) are the typical features of welding. According to the crystallization temperature of the spherulites, this process could occur around 500-800 ${ }^{\circ} \mathrm{C}$ (Breitkreuz 2015). The deformed juvenile components of the oriented samples form the so-called eutaxitic texture of the rocks (Gifkins et al. 2005a,b; Wilcock et al. 2013). On the other hand, samples having moderately or not deformed, X and Y shaped altered glass shards and slightly oriented, altered pumices (Fig. II.3/e, f) cannot be interpreted as welded volcanic rocks, by lacking well-visible orientation.

Preliminary X-ray powder diffraction (XRD) analyses of K-feldspar crystals suggest adularia composition, referring to K-metasomatism. K-feldspars are unequivocally more abundant than plagioclase; however, the accurate modal composition cannot be given because of the subsequent alterations. The following order was measured: quartz $>$ K-feldspar > plagioclase feldspar > biotite > pyroxene, suggesting rhyolitic composition.

Based on the observed textural features, including the altered, devitrified pumices and glass shards, the poor sorting of the components and the presence of fragmented phenocrysts (including crystalloclasts), the studied samples in the Western Mecsek Mts were deposited by a pumiceous pyroclastic flow, and could be interpreted as ignimbrites (McPhie et al. 1993; Paulick and Breitkreuz 2005). Well-visibly oriented, eutaxitic rocks were affected by welding processes (eutaxitic, welded, crystal-rich, pumice-bearing lapilli tuffs), while not oriented samples (showing typical X and Y shaped glass shards) are non-welded, crystal-rich, pumice-bearing lapilli tuffs.

\subsubsection{Northern foreland of the Villány Mts}

\subsubsection{Bisse-1 borehole}

\section{Description}

Felsic volcanic rocks consist of fragmented phenocrysts $(20-30$ vol\%) and microcrystalline or cryptocrystalline groundmass crosscut by perlitic cracks filled with secondary minerals (e.g., quartz, feldspar, clay minerals, sericite and hematite; Fig. 
II.4/a-e). In case of one sample, irregular, strongly altered, slightly oriented remnants of devitrified pumices were identified, replaced by mosaic quartz (Fig. II.4/f).

Rock-forming minerals are quartz, K-feldspar, plagioclase and biolite. Quartz crystals (10-15 vol\%; Fig. II.4/c) are euhedral or subhedral, resorbed, often crosscut by fractures. Their average size is $700-750 \mu \mathrm{m}$, while the coarsest grains are up to $1-1.2$ $\mathrm{mm}$.
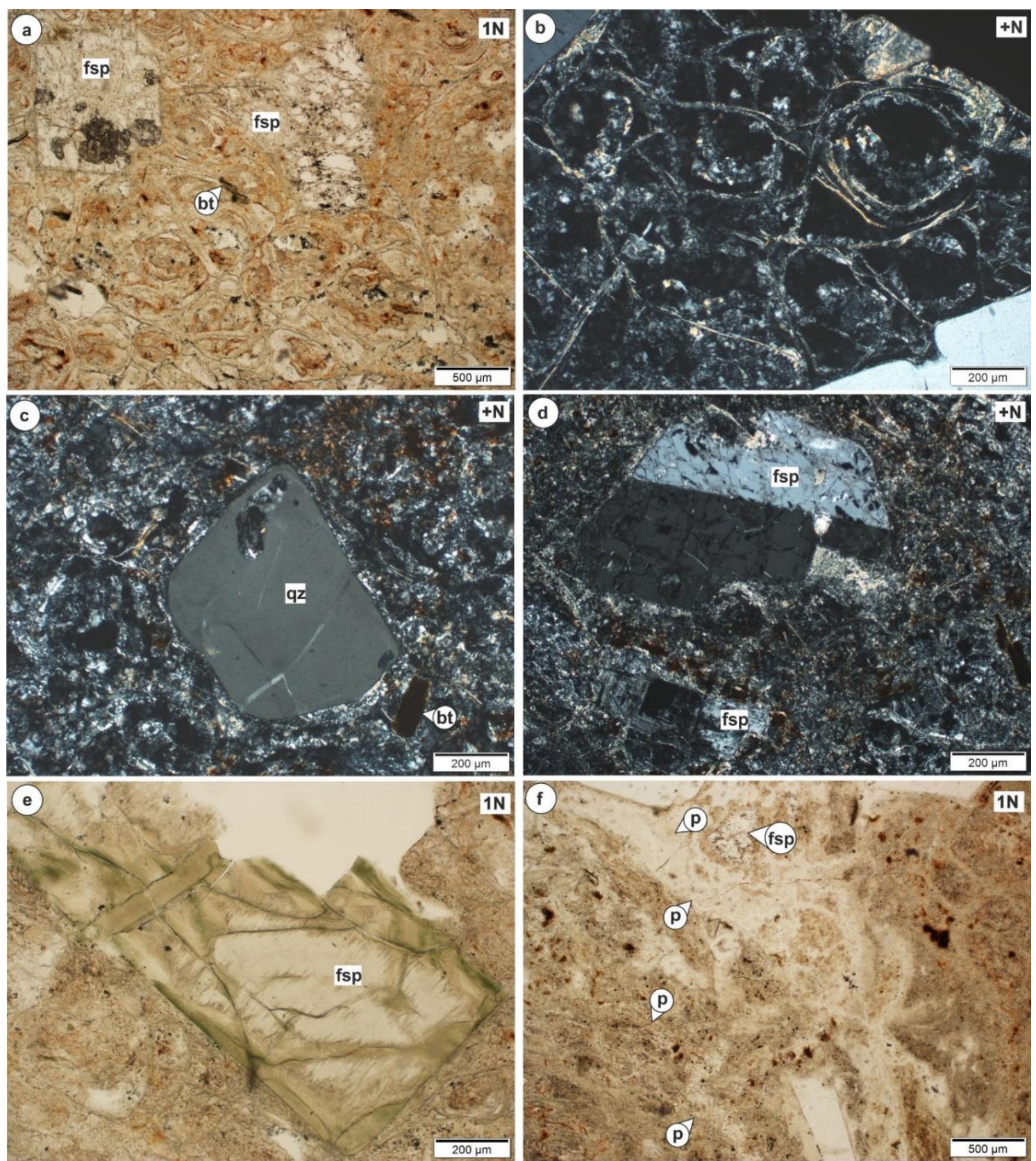

Figure II.4 Photomicrographs of the studied samples of the Bisse-1 borehole (depth: 1100 m). a Relict perlitic texture with porphyric feldspar and biotite crystals; b Characteristic relict perlitic texture; $\mathbf{c}$ Subhedral quartz and biotite in a relict perlitic sample; d K-feldspar (above) and plagioclase (below) in a fine-grained groundmass; e Argillitized euhedral, tabular plagioclase; f Microcrystalline, relict perlitic groundmass with remnants of oriented, altered pumices and fragments of feldspar crystals. $b t$ biotite, $f s p$ feldspar, $p$ altered pumice, $q z$ quartz, $1 N$ plane polarized light, $+N$ crossed polars 
Feldspars (10-15 vol\%) are dominantly subhedral (Fig. II.4/d), rarely euhedral (tabular; Fig. II.4/e), their average size is $\sim 800 \mu \mathrm{m}$, while the largest crystals are up to $1.5 \mathrm{~mm}$. Relatively fresh (occasionally perthitic or sericitic) K-feldspars and strongly altered, argillitized (showing greenish tones, most possibly celadonite; Fig. II.4/e), sericitized or carbonatized plagioclase feldspars were equally observed.

Biotite crystals (1-3 vol\%, faded or replaced by opaque minerals; Fig. II.4/a, c) were also found. Their general size is $250-350 \mu \mathrm{m}$. As dispersed, fine-grained components in the groundmass opaque minerals and as accessory mineral zircon occur.

\section{Interpretation}

Perlitic texture is the result of the hydration of the coherent glass shards in the fine groundmass, followed by significant volume growth. For the formation of such cracks, at least 3-5\% water content is neccessary (McPhie et al. 1993; Szepesi 2007; Szepesi and Kozák 2008). Perlitic texture refers to primarily glassy groundmass that could be the feature of pyroclastic rocks (e.g., ignimbrites) and rapidly cooled lavas (e.g., rhyolite), too (McPhie et al. 1993; McArthur et al. 1998). The relict texture defined by the secondary-mineral-filled perlitic cracks is the result of the alteration of the original, classical perlitic texture in which the forms of the previous fractures could resemble to the devitrified glass shards of the pyroclastic rocks ('false siliceous/phyllosilicate shards'; Allen 1988; Breitkreuz 2015).

According to the mineralogical composition and the texture, the studied samples of the Bisse-1 borehole are rhyolites; perlite and pumiceous perlite facies variations were identified. The formation of such rocks was most possibly associated with the outer, the transitional or the marginal zones of a rhyolitic lava dome/flow (Fink and Manley 1987; McPhie et al. 1993; Stevenson et al. 1994; Richnow 1999; Szepesi 2007; Szepesi and Kozák 2008).

\subsubsection{Peterd-1 borehole}

\section{Description}

The porphyric samples consist of phenocrysts of various size (30-40 vol\%), fine-grained groundmass (45-50 vol\%) and irregular or deformed, flattened, colourless or light, yellowish brown, oriented, altered pumices (5-10 vol\%; Supplementary Figure II.4/a, b 
and Fig. II.5/a, b). In microscale, the orientation is borne by the deformed, devitrified glass shards (Fig. II.5/c).

Altered, devitrified pumices are dominantly deformed around the coarser phenocrysts. Axiolitic rims and spherulites inside them are common. They are non-porous and filled with quartz and feldspar phenocrysts and mosaic quartz (in the previous pores).
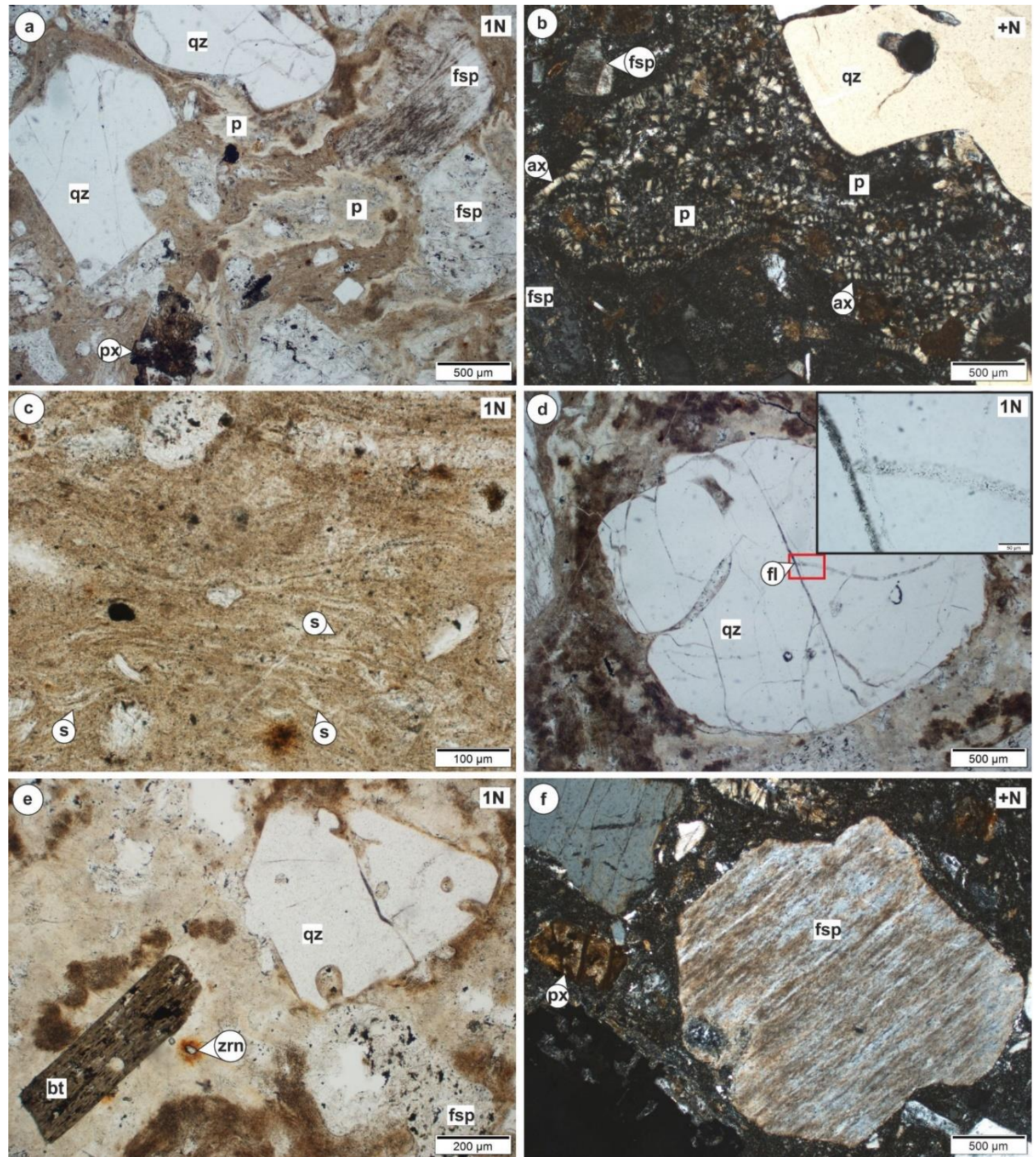

Figure II.5 Photomicrographs of the studied samples of the Peterd-1 borehole (depths: $1240.0 \mathrm{~m}$ and unknown). a Typical textural image with porphyric, subhedral phenocrysts and altered pumices; $\mathbf{b}$ Devitrified pumice with axiolites at the rims; $\mathbf{c}$ Altered glass shards in the fine-grained groundmass; $\mathbf{d}$ Subhedral, resorbed quartz with fluid inclusion assemblages; e Resorbed quartz, fragmented feldspar, euhedral biotite and accessory zircon; $\mathbf{f}$ Pectinate feldspar (adularia) and altered pyroxene. $a x$ axiolite, $b t$ biotite, $f l$ fluid inclusion assemblages, $f s p$ feldspar, $p$ altered pumice, $p x$ pyroxene, $q z$ quartz, $s$ altered glasss shards, zrn zircon, $1 N$ plane polarized light, $+N$ crossed polars. The scale of the blowup picture (d) is $50 \mu \mathrm{m}$ 
The size of the juvenile fragments reduces from the $\sim 1 \mathrm{~cm}$-sized pumices to the smallest $(\sim 100 \mu \mathrm{m})$ altered glass shards.

Rock-forming minerals are fragmented quartz, feldspars and opaque pseudomorphs after pyroxene and biotite showing no orientation. Quartz crystals (10-15 vol\%; Fig. II.5/a, d, e) have an average $\sim 1 \mathrm{~mm}$ and a maximum size of $2.5-3 \mathrm{~mm}$. They are dominantly subhedral, resorbed; however, euhedral crystals as well as crystalloclasts $(\sim 100-200 \mu \mathrm{m})$ occur, too. Inside them, fluid inclusion assemblages are common (Fig. II.5/d).

Feldspar crystals (15-20 vol\%; Fig. II.5/a, f) have an average size of $\sim 700 \mu \mathrm{m}$, but coarser grains could be larger than $2 \mathrm{~mm}$. They are often altered and subhedral; euhedral (tabular) crystals are rare. In the samples, macroscopically iridescent (Supplementary Figure II.4/a, b) K-feldspars are the dominant (80\%), showing the dense alternation of inclusion-rich and inclusion-free domains (pectinate appearence) or being argillitized, while plagioclase crystals are always altered, sericitized and/or carbonatized.

Mafic components are present in the samples in $\sim 5 \mathrm{vol} \%$ that are pseudomorphs after pyroxene and biotite having an average size of $\sim 650 \mu \mathrm{m}$. Altered pyroxenes (up to $1 \mathrm{~mm}$; Fig. II.5/a, f) are carbonatized and replaced by opaque minerals at the rims and along the fractures. Biotite crystals (up to $\sim 500-600 \mu \mathrm{m}$; Fig. II.5/e) are euhedral and almost completely replaced by opaque minerals. As accessory minerals broken zircon crystals (Fig. II.5/e) and apatite were found.

\section{Interpretation}

The oriented texture of the rocks is defined by the deformed, coherent juvenile components (devitrified pumices and glass shards), being the result of the compaction due to the lithostatic pressure (fiamme; Gifkins et al. 2005a,b). Axiolitic rims and spherulites were formed by high temperature crystallization (Breitkreuz 2013). The observed textural features are typical of welding in pyroclastic rocks, resulting in oriented, eutaxitic textures (Gifkins et al. 2005a,b; Paulick and Breitkreuz 2005; Wilcock et al. 2013).

Among the phenocrysts, the samples are dominated by K-feldspars; thus, the mineralogical composition suggests rhyolitic melt. The poor-sorting of the rocks is another evidence of the pyroclastic origin. On the whole, the felsic volcanic rocks of the Peterd-1 borehole are altered, welded, crystal-rich, pumice-bearing lapilli tuffs. Based on 
the homogeneous appearance of the drill cores from different depths of the borehole, the whole penetrated sequence could have been one eruptive unit.

\subsubsection{Szava-1 borehole}

\section{Description}
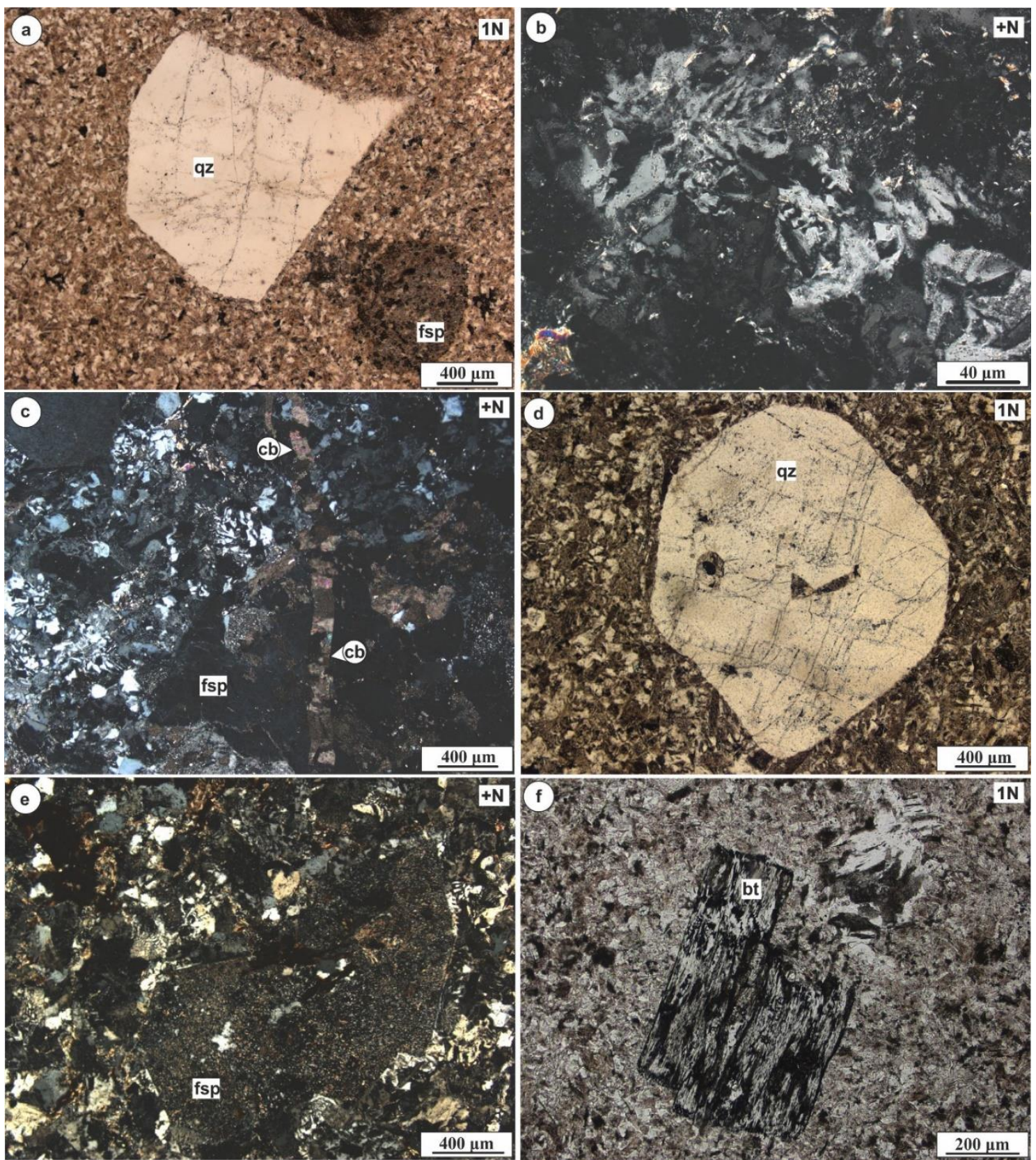

Figure II.6 Photomicrographs of the studied samples of the Szava-1 borehole (depth: 353.5-477.8 m). a Porphyric microholocrystalline texture with subhedral quartz and feldspar crystals; b Sample having granophyric texture; c Vein, filled with carbonate crosscutting the sample; d Euhedral, mildly resorbed quartz; e Altered, subhedral feldspar crystal; f Biotite crystal, faded and partially replaced by opaque minerals. $b t$ biotite, $c b$ carbonate, $f s p$ feldspar, $q z$ quartz, $1 N$ plane polarized light, $+N$ crossed polars

The texture of these samples is porhyric microholocrystalline, the rock-forming phenocrysts (25-30 vol\% quartz, K-feldspar, plagioclase and biotite) in the fine 
groundmass are dominantly mm-to-cm-sized (Fig. II.6). Orientation was not observed in the rocks, but they are crosscut by fractures and vein fillings (Supplementary Figure IV.4/c). The groundmass consists of quartz and feldspar microcrystals; as the alteration feldspar-rich parts, sericite and clay minerals also occur in it as well as smaller fragments of biotite. In some samples, granophyric groundmass was observed, too (Fig. II.6/b). The grain-size of the groundmass crystals is variable, in some samples it is homogeneous (equigranular), while in case of other rocks of the borehole inhomogeneous (inequigranular) matrix was found.

Vein filling minerals are dominantly carbonate (Fig. II.6/c), clay minerals, quartz (+ feldspar) and hematite. The phenocrystals are generally fragmented, too. Moreover, the latter is very characteristic of the samples that have inhomogeneous groundmass. These volcanic rocks are crosscut by more fractures and/or vein fillings.

Quartz crystals (15-20 vol\%; Fig. II.6/a, d) are subhedral, rarely euhedral, resorbed, often having embayments and fluid inclusion assemblages inside. Their avarage size is $1.5-2 \mathrm{~mm}$, while the coarser cystals are $\sim 5 \mathrm{~mm}$ large. The latter were fragmented into multiple pieces; however, as the result of subsequent processes, partially or completely 'rehealed'.

Feldspar crystals (10-15 vol\%; Fig. II.6/c, e) are fragmented, dominantly subhedral and strongly altered. Their average size is $3-3.5 \mathrm{~mm}$; however, the largest crystals might reach 8-9 $\mathrm{mm}$. Both tabular K-feldspars having Carlsbad twinning and polysynthetic twinned, sericitized plagioclase feldspars occur. Argillitization and carbonatization are typical in the fractures and on their surface, as well.

Biotite crystals (1-3 vol\%; Fig. II.6/f) are not present in iu samples. They are generally altered, faded or partially replaced by opaque minerals, occasionally fragmented into discrete sheets. Their average size is $\sim 400 \mu \mathrm{m}$, while the largest crystals are up to $2 \mathrm{~mm}$. As accessory components zircon and apatite are common.

\section{Interpretation}

Porphyric microholocrystalline and granophyric textures are basically associated with intermediate and silicic volcanic rocks; the latter refers to slow cooling (McPhie et al. 1993). According to the mineralogical composition, samples of the Szava-1 borehole are rhyolites. However, all the observed textural features cannot exclude the previously supposed (Barabásné Stuhl 1988) subvolcanic origin. On the other hand, the restricted 
number of the available drill cores, the intense post-magmatic alteration and the fragmentation of the materials do not make it possible to distinguish between subvolcanic rocks and lavas. In case of rhyolitic lava flows/domes and shallow-level intrusions, the homogeneous, equigranular groundmass dominantly represents the core facies of the intrusion/extrusion, while intense fragmentation/brecciation and inhomogeneous groundmass is the typical feature of the carapace facies (Paulick and Breitkreuz 2005; Breitkreuz 2015). Regarding altered volcanic rocks, similar appearence might have been created by pseudobrecciation which is the incomplete breakdown of the primary texture (Allen 1988). However, it must be taken into consideration that the rock samples of the $5.2 \mathrm{~m}$ thick contact zone above the volcanite in the Szava-1 borehole were previously interpreted as tectonites (Fazekas 1978). Based on the well data of this area (Fazekas 1978; Barabásné Stuhl 1988), tectonics could play an important role in the brecciation.

\subsubsection{Vókány-2 borehole}

\section{Description}

Samples of the Vókány-2 borehole were classified into two distinct groups. (1) The major part of the volcanic rocks have recrystallized, felsitic (Fig. II.7/c, d) texture with a groundmass of quartz and feldspar microcrystals (70-80 vol\%). Rock-forming minerals are porphyric quartz, K-feldspar and plagioclase having a size of several mm (Fig. II.7/bd). In the fine-grained matrix, spherulites occur; the largest ones might reach the size of $\sim 100 \mu \mathrm{m}$ (Fig. II.7/a). In the groundmass, disperse opaque and clay minerals as well as bioitite crystals are present.

Quartz crystals (10-15 vol\%; Fig. II.7/b, c) are subhedral, resorbed, often having embayments and fluid inclusion assemblages inside. Their average size is $\sim 900 \mu \mathrm{m}$, while the maxium size is $\sim 2 \mathrm{~mm}$. Rarely shard-like, broken crystals and 'rehealed' quartz grains also occur.

Feldspars (10-15 vol\%; Fig. II.7/b, d) are dominantly subhedral, resorbed and have embayments, but some euhedral, tabular crystals are also present. Their average size is $1-1.5 \mathrm{~mm}$, while the maximum size is $\sim 2.5 \mathrm{~mm}$. The samples are dominated by $\mathrm{K}$ feldspars; however, plagioclase crystals could occur, too. Sericitization and argillitization are typical alterations in these samples.

Biotite crystals (Fig. II.7/a) are relatively rare (1-2 vol\%), their average size is $500 \mu \mathrm{m}$, while the maximum size is $\sim 1 \mathrm{~mm}$. They are often faded or replaced by opaque 

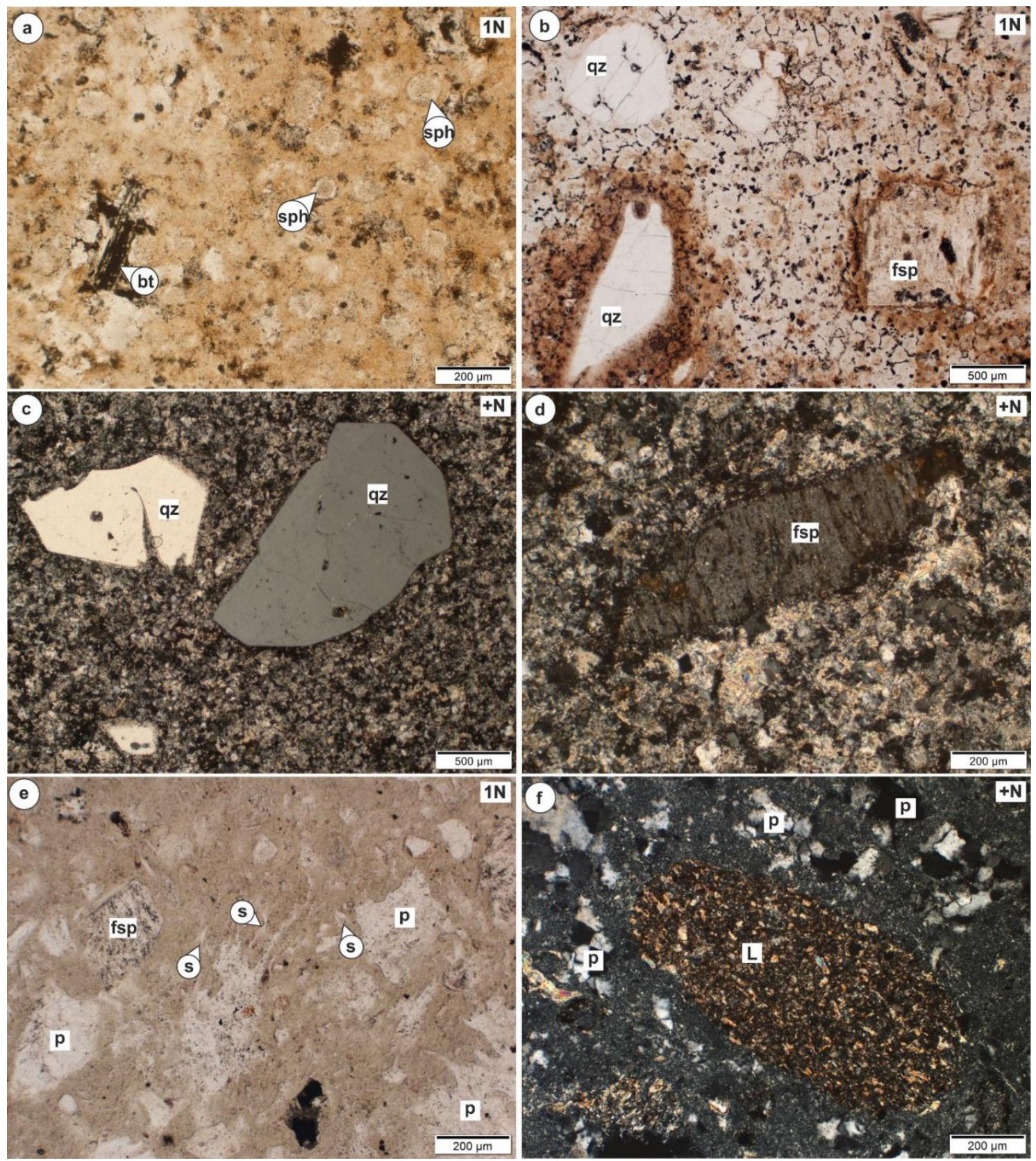

Figure II.7 Photomicrographs of the studied samples of the Vókány-2 borehole (a-d depths: $1000.0 \mathrm{~m}$ and $1139.6 \mathrm{~m}$; e-f depht: $774.8 \mathrm{~m}$ ). a Recrsytallized groundmass with spherulites and a biotite crystal; b Porphyric crystals in a sample having felsitic texture; c Subhedral, resorbed, fragmented quartz crystals; d K-feldspar in a sericitized sample having felsitic texture; e Altered glass shards and pumices in a pyroclastic sample; f Altered pumices replaced by mosaic quartz and a lithic clast in a pyroclastite. $b t$ biotite, $f s p$ feldspar, $L$ lithic clast, $p$ altered pumice, $q z$ quartz, $s$ altered glass shard, $s p h$ spherulite, $1 N$ plane polarized light, $+N$ crossed polars

minerals. As accessory phases zircon crystals were barely observed in the samples; they dominantly occur as inclusions in biotite (Supplementary Figure II.6/a).

(2) Different petrographic features were observed in case of one sample (Fig. II.7/e, f), representing the uppermost (available) depth of the volcanic sequence in the borehole $(774.8 \mathrm{~m})$. Its groundmass crystals have smaller grain size and all the components show poor sorting in general. In the groundmass, devitrified, altered glass 
shards and pumices, replaced by mosaic quartz are present. Juvenile components bear no kind of orientation; the texture of the sample is relict vitroclastic.

The rock-forming minerals are fragmented and resemble to the mineral assemblage of the previously described group of felsic volcanic rocks in the borehole; however, the presence of smaller crystalloclasts is notable. As accessory components zircon crystals are relatively rare. Some former pores, filled with mosaic quartz are also present in the sample.

In contrast to the former group, a reddish sedimentary lithic clast (siltstone according to the grain size; Fig. II.7/f), moreover, carbonized plant remains $(\sim 100 \mu \mathrm{m})$ were also observed.

\section{Interpretation}

Recrystallized, felsitic and spherulitic textures of the major group of the studied felsic volcanic rocks are the result of devitrification of the primarily glassy groundmass, and these textures are typical of silicic extrusive rocks (McPhie et al. 1993). Although spherulites could occur in lavas and pyroclastic rocks, too (Breitkreuz 2013), the textural features (e.g., the lack of juvenile components and lithics, barely fragmented phenocrysts) suggest that these rocks are rhyolitic subvolcanic rocks or lavas. On the other hand, it cannot be excluded that the recrystallization of the samples was so intense that primary textural features (e.g., eutaxitic texture of welded ignimbrites) have been completely modified and overprinted, being unrecognizable now. Thus, it is not possible to come up with the unequivocal implications about the formation of these rocks that were interpreted in the former reports of uranium ore exploration as 'microgranite porphyry' (shallowlevel intrusion) or volcanic vent facies (Kassai 1976; Barabásné Stuhl 1988).

On the other hand, in case of the unique sample representing the uppermost part of the volcanic sequence, the previous (tuff; Fazekas 1978; Barabásné Stuhl 1988) categorization was verified as it proved to be a rhyolitic pyroclastic rock.

\subsubsection{Egerág-7 borehole}

\section{Description}

Felsic volcanic rocks of the Egerág-7 borehole were divided into two major groups based on the petrographic features. Samples representing the shallower depths of the borehole (e.g., Supplementary Figure II.4/e) consist of fine-grained groundmass, poorly-sorted 

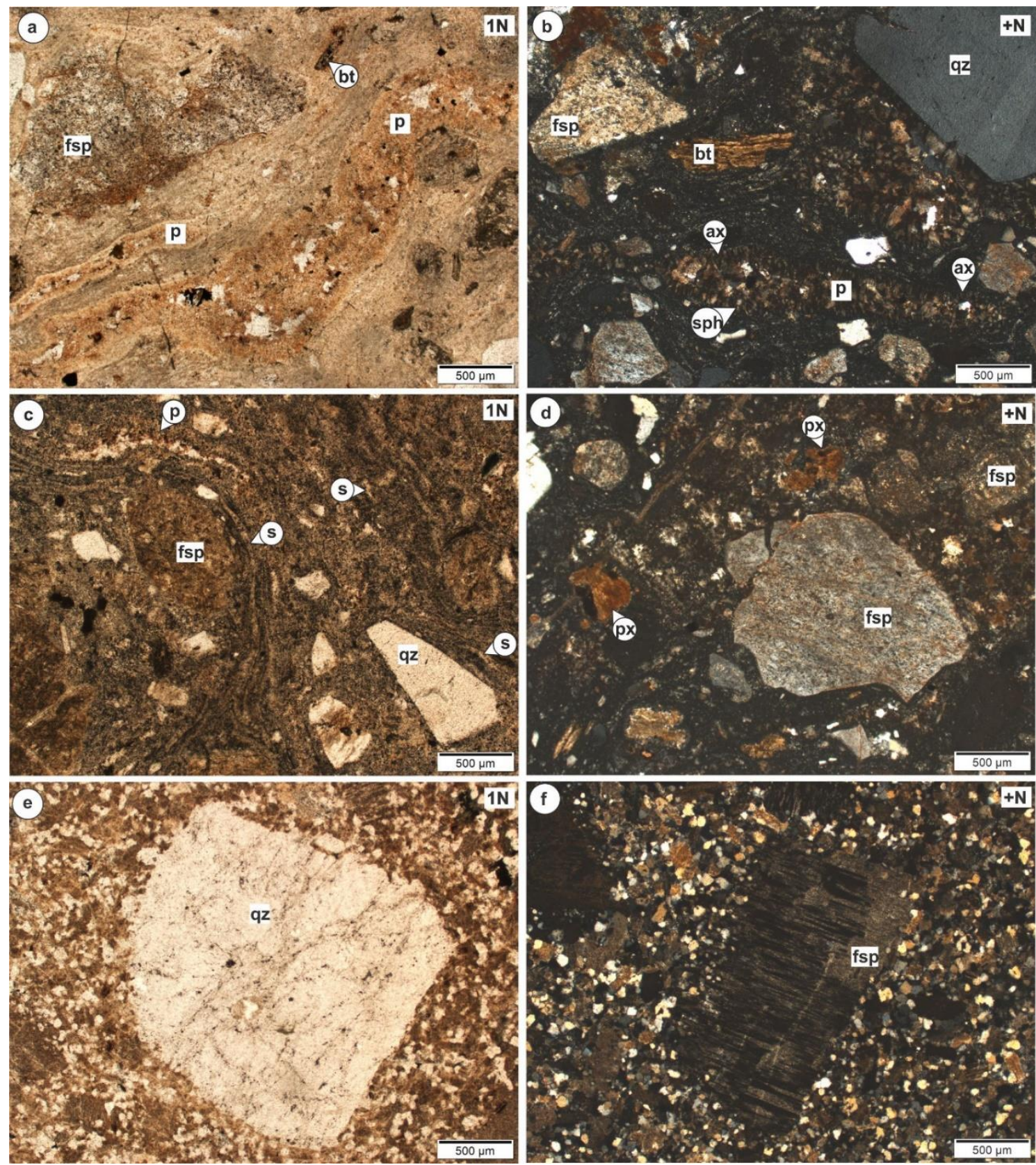

Figure II.8 Photomicrographs of the studied samples of the Egerág-7 borehole (a-d depth: 673.3-753.8 m; e-f depth: $1200 \mathrm{~m}$ ). a Oriented, devitrified pumices, fragmented feldspar and biotite crystals; $\mathbf{b}$ Altered pumice with axiolites at the rims and spherulites inside it, and fragmented, subhedral crystals; c Oriented, altered pumices and devitrified glass shards; d K-feldspar and altered pyroxenes; e Quartz crystal having fringy margin; f Porphyric plagioclase in a sample having microholocrystalline texture. $a x$ axiolite, $b t$ biotite, $f s p$ feldspar, $p$ altered pumice, $p x$ pyroxene, $q z$ quartz, $s$ altered glass shard, $s p h$ spherulite, $z r n$ zircon, $1 N$ plane polarized light, $+N$ crossed polars

phenocrysts of various size, oriented, deformed, flattened, devitrified pumices and deformed, altered glass shards in the matrix (Fig. II.8/a-d). Devitrified glass shards usually form a coherent band together with the flattened pumices, creating a well-visibly oriented texture.

Deformed, altered pumices (up to mm-size) are often axiolitic at the rims and spherulites (Fig. II.8/b) occur inside them. Devitrified juvenile components are filled with 
secondary, mosaic quartz and feldspar microcrystals. The previous glass shards were also replaced by quartz and feldspar, they are dominantly flattened (Fig. II.8/c), the largest ones could reach $\sim 200 \mu \mathrm{m}$.

Rock-forming minerals are quartz, K-feldspar, plagioclase and pseudomorphs after pyroxene and biotite. Their size ranges from $\mu \mathrm{m}$ to $\mathrm{mm}$, and they are often fragmented.

Quartz crystals ( 15 vol\%; Fig. II.8/b, c) are euhedral or subhedral, fragmented. Resorbed crystals, having embayments are also common. Their size varies between the $\mu \mathrm{m}$-sized crystalloclasts and the mm-sized porphyres (up to $\sim 4 \mathrm{~mm}$ ).

Feldspar crystals (15-20 vol\%; Fig. II.8/a-d) are euhedral, tabular or subhedral, resorbed and/or fragmented. Their average size is $\sim 700 \mu \mathrm{m}$, and the maximum size is $\sim$ $3 \mathrm{~mm}$. Both perthitic or argillitized K-feldspars, having Carlsbad twinning and polysynthetic twinned, sericitized plagioclase crystals occur; however, the former are more frequent in the upper part of the volcanic sequence of the borehole.

Pseudomorphs after pyroxene and biotite are relatively rare (4-5 vol\%, measured together). Pyroxenes (Fig. II.8/d) were replaced by carbonate, the maximum size of the crystals is $\sim 500 \mu \mathrm{m}$. Biotite crystals (Fig. II.8/a, b) are euhedral, partially replaced by opaque minerals or chlorite and sometimes faded. Rarely relatively fresh, idiochromatic crystals occur, too. Their maximum size is $\sim 1-2 \mathrm{~mm}$.

In the groundmass of the samples zircon crystals are common. As further accessory components tourmaline and garnet were found. Garnet crystals (Supplementary Figure II.6/c, d) are subhedral, resorbed and fragmented. Their size varies from the few$\mu \mathrm{m}$-sized fragments to the $\sim 600-700 \mu \mathrm{m}$ large crystals. In the latter, inclusions were idenified, as well.

In contrast to the previously described samples, the lowermost part of the Egerág7 borehole is represented by a porphyric microholocrystalline sample (Supplementary Figure II.4/f and Fig. II.8/e, f). Its groundmass is equigranular and consists of quartz and feldspar crystals $(\sim 10-100 \mu \mathrm{m})$, locally carbonatized. Rock-forming quartz ( 10 vol\%) and feldspar (15-20 vol\%) porphyres are euhedral or subhedral, resorbed. Their margins are not well-defined (sharp), rather fringy showing overgrowth in the direction of the matrix (Fig. II.8/e). Contrary to the upper part of the volcanic sequence, these samples of the borehole contain less quartz crystals. Moreover, polysynthetic twinned, occasionally sericitized plagioclase crystals (Fig. II.8/f) are more frequent than the argillitized, perthitic K-feldspars. 


\section{Interpretation}

Based on the petrographic features, the upper part of the volcanic sequence (432.0-753.8 m) was interpreted as a set of pyroclastics; the observed samples are altered, welded, crystal-rich, pumice-bearing lapilli tuffs. The deformed, flattened shape of the altered pumices is the characteristic feature of welding. Axiolitic rims and shperulites are the results of high temperature crystallization (Gifkins et al. 2005a,b; Breitkreuz 2013; Wilcock et al. 2013). Quartz-richness of the samples and the dominance of K-feldspar indicate rhyolitic composition.

In case of the lowermost (available) drill core of the sequence (depth: $\sim 1200 \mathrm{~m}$ ) no textural feature of pyroclastic rocks was observed. The porphyric microholocrystalline rock of subvolcanic or lava origin differs according to the mineralogical composition as well, suggesting dacitic melt.

\subsubsection{Szalánta-3 borehole}

\section{Description}

In contrast to the previously described and interpreted boreholes of the northern foreland of the Villány Mts, the volcanic sequence of the Szalánta-3 borehole was studied by more samples (depht: 299.0-581.7 m), due to the archive collection of the Mecsek Ore Minning Company. Sixteen samples of the thin section collection of this volcanic-sedimentary sequence represented the Gyürüfü Rhyolite (depht: 299.0-548.7 m).

In case of this borehole, samples were divided into two groups, too. Felsic rocks of the upper part of the volcanic sequence show homogeneous appearence (299.0-404.8 $\mathrm{m}$ and $505.5 \mathrm{~m}$ ), while two samples strinkingly differ from them (depths: 459.3 and 548.7 $\mathrm{m})$.

Samples of the first, major group (e.g., Supplementary Figure II.4/d) consist of light brownish red, fine-grained groundmass and porphyric crystals (quartz, K-feldspar, plagioclase and biotite). The texture is variously oriented, the orientation is borne by devitrified juvenile components (pumices and glass shards). In the partially or not oriented samples, (micro)felsitic matrix of quartz, feldspar and sericite is the dominant.

Pumices are basically oriented (Fig. II.9/a), flattened and deformed around the porphyric crystals (Fig. II.9/a, c). Their rims are axiolitic (Fig. II.9/c) and inside them spherulites occur; as the result of recrystallization pumices are replaced by mosaic quartz 

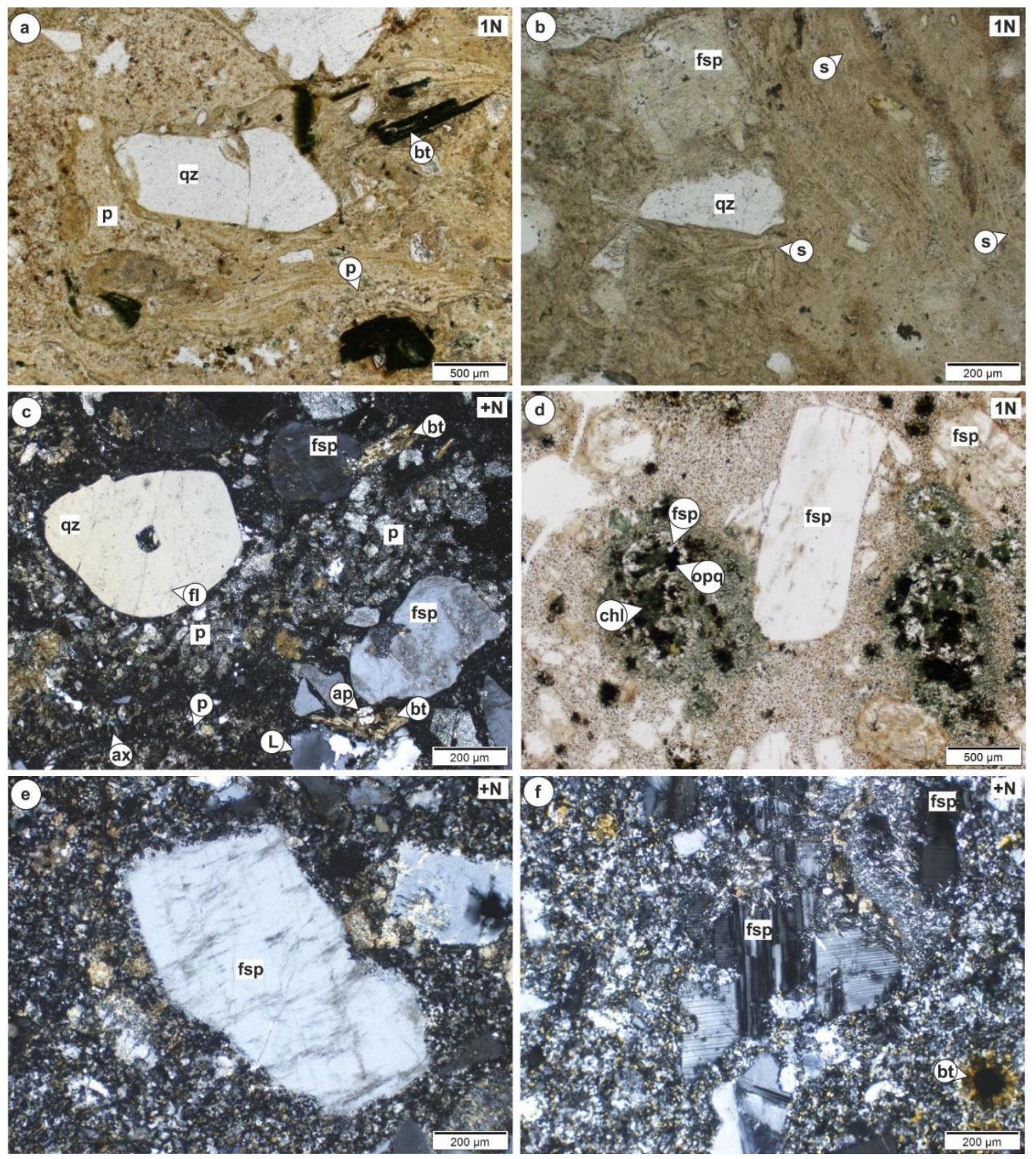

Figure II.9 Photomicrographs of the studied samples of the Szalánta-3 borehole (a-d depth: 299.0-404.8 $\mathrm{m}$ and $505.5 \mathrm{~m}$; e-f depths: 459.3 and $548.7 \mathrm{~m}$ ). a Altered pumices, subhedral, resorbed quartz and biotite replaced by opaque minerals; b Subhedral, fragmented quartz and feldspar crystals, and altered glass shards, c Altered pumices, replaced by as mosaic quartz and resorbed or fragmented crystals around them; d Clots of biotite/chlorite, quartz, feldspar and opaque minerals in a felsitic volcanic rock; $\mathbf{e}$ Porphyric K-feldspar having fringy rims; f Crown-like structure of biotite crystals around an opaque mineral, and a subhedral plagioclase. $a p$ apatite, $a x$ axiolite, $b t$ biotite, $c b$ carbonate, $c h l$ chlorite, $f l$ fluid inclusion assemblages, $L$ lithic clast, $o p q$ opaque mineral, $p$ altered pumice, $q z$ quartz, $s$ altered glass shard, $1 N$ plane polarized light, $+N$ crossed polars

and feldspar. The primary textural features were often overprinted or modified. Shape of the devitrified glass shards is changeable from elongated, deformed shards to $\mathrm{X}$ and $\mathrm{Y}$ shaped ones (Fig. II.9/b). Their average size is $~ 100-200 \mu \mathrm{m}$.

Rock-forming minerals are porphyric, fragmented quartz, K-feldspar, plagioclase and biotite. Quartz crystals ( 10 vol\%; Fig. II.9/a-c) are euhedral or subhedral, resorbed 
with embayments and fluid inclusion assemblages inside them (Fig. II.9/c). Their average size is $\sim 700 \mu \mathrm{m}$, while the largest crystals could reach $2.5-3 \mathrm{~mm}$.

Feldspar crystals (10-15 vol\%; Fig. II.9/b-d) are dominantly subhedral, resorbed; euhedral tabular crystals are rare. Carlsbad twinned, perthitic K-feldspars as well as sericitized, chloritized polysynthetic twinned plagioclase crystals occur. Their average size is $\sim 600 \mu \mathrm{m}$, while the largest grains are $\sim 3 \mathrm{~mm}$.

Biotite crystals (1-3 vol\%; Fig. II.9/a, c) are dominantly euhedral; however, fragmented and curved (due to the compaction) crystals are common, too (Fig. II.9/c). Their average size is $\sim 200 \mu \mathrm{m}$, while the largest crystals could reach $0.5 \mathrm{~mm}$. At the uppermost part of the volcanic sequence (depth: $300 \mathrm{~m}$ ) biotite crystals are almost completely chloritized, while in the samples of greater depths idiochromatic, relatively fresh crystals were found.

As accessory minerals zircon and apatite (Fig. II.9/c; Supplementary Figure II.6/b) are common. Moreover, subhedral, fragmented garnet crystals occur in the samples (Supplementary Figure II.6/e, f). The maximum size of the garnet crystals is $\sim 800 \mu \mathrm{m}$. They were often affected by intense chloritization and opaque inclusions were found inside them. Garnets crystals appear as inclusion in the rock-forming minerals (e.g., Kfeldspar) and also show intergrowth with the latter. In subordinate amount lithic clasts consisting of polycrystalline quartz and biotite (of most possibly metamorphic origin) were also found (Fig. II.9/c).

The other group of felsic volcanic rocks in the Szalánta-3 borehole consists of microfelsitic-felsitic groundmass of quartz, feldspar and sericite, and porphyric crystals (dominantly plagioclase and K-feldspar; Fig. II.9/d-f); its texture shows no orientation. The felsitic-porphyric arrangement is interrupted by clots that consist of biotite/chlorite, quartz, feldspar, opaque minerals and carbonate (Fig. II.9/d). The size of these clots ranges between $\sim 100 \mu \mathrm{m}$ and 1-2 $\mathrm{mm}$. In these mineralizations, biotite crystals appear crown-likely around opaque minerals (Fig. II.9/f).

Feldspar crystals (25-30 vol\%) are dominantly subhedral, resorbed and show overgrowth in the direction of the matrix (Fig. II.9/e). Their size varies from $\sim 100 \mu \mathrm{m}$ up to 2-3 $\mathrm{mm}$. In contrast to the previous samples, the relatively fresh crystals are more frequent, the altered ones are sericitized. Polysynthetic twinned plagioclase (Fig. II.9/f) and Carlsbad twinned K-feldspar crystals (Fig. II.9/e) equally occur.

Moreover, larger, chloritized biotite crystals $(\sim 500 \mu \mathrm{m})$ are present in these samples. As accessory mineral zircon grains are common in the groundmass. 
Contrary to the first major group of volcanic rocks in the borehole, these rocks contain notably less quartz crystals, dominantly as groundmass microcrysts or smaller fragments (in 100-200 $\mu \mathrm{m}$ size).

\section{Interpretation}

Samples of the first major group have unequivocally pyroclastic origin. Pumices bear similar features to those of the upper part of the volcanic sequence of the Egerág-7 borehole, including strong deformation, elongation, devitrification and the lack of coarser phenocrysts inside them. However, among the pyroclastic samples of the Szalánta-3 borehole slighter petrographic differences were observed in case of the juvenile components; thus, it is feasible that intensity of welding was different along the sequence of the borehole. These rocks of rhyolitic composition were interpreted as altered, variously welded, crystal-rich, pumice-bearing lapilli tuffs corresponding to the pyroclastic rocks of the Egerág-7 borehole.

Similarly to the upper part of the volcanic sequence of the borehole, these samples bear strongly altered (chloritized, opaque mineralized) garnet crystals. These alterations point to siginificant Fe-content (almandine composition) that could be in correspondence with the results of the previous SEM analyses of Jakab (2005). In these samples of the Szalánta-3 borehole, the intergrowth of K-feldspar and garnet crystals as well as the garnet crystals occurring as inclusions in the rock-forming minerals indicate their primary magmatic origin.

In contrast to the former rocks, felsitic-microfelsitic texture of the other samples of the borehole refers to intense recrystallization that is the feature of felsic lavas (McPhie et al. 1993). According to the textural features and mineralogical composition, these samples show similarity to the lowermost part of the Egerág-7 borehole ( $1200 \mathrm{~m})$. Quartz is subordinate, while among the feldspar crystals plagioclase in the dominant, suggesting rhyodacitic/dacitic composition that differs from the rhyolitic pyroclastic rocks of the upper part of the volcanic sequence. It is feasible that these rocks correspond to the lower lithology (subvolcanic rock or lava) of the Egerág-7 borehole. Clots consisting of multiple minerals were not found in case of any other material at the northern foreland of the Villány Mts. Crown-like biotite crystals around opaque minerals were most possibly crystallized together with the primary texture. In these 
mineralizations, chlorite was formed as the alteration of the biotite, while carbonate could be derived from the altered groundmass.

\subsection{Discussion}

As the Permian sequence in S Transdanubia was not affected by Alpine regional metamorphism (Fülöp 1994; Barabás and Barabásné Stuhl 1998), all the textural features observed in the felsic volcanic samples of the area were interpreted as the results of cooling and post-magmatic processes. Based on the petrographic analyses and the reinterpretation of the archive reports of the uranium ore exploration, various types of felsic volcanic rocks were distinguished in the studied area (Supplementary Table II.2).

Samples of the single outctrop of the Gyürüfü Rhyolite in the Western Mecsek Mts proved to be rhyolitic pyroclastic rocks, crystal-rich, pumice-bearing lapilli tuffs, in contrast to their previously documented lava origin (Szederkényi 1962; Barabásné Stuhl 1988; Fülöp 1994; Barabás and Barabásné Stuhl 1998). Based on the microscopic view, two distinct lithofacies were separated among the outcrop rock samples. (1) Pyroclastic rocks that consist of oriented, strongly flattened, deformed, devitrified pumices and glass shards, forming a coherent band (fiammes) indicate intense welding. These samples (e.g., the bedrock of the outcrop and those ones collected nearby) were classified as eutaxitic, welded, crystal-rich, pumice-bearing lapilli tuffs and might represent the moderate to greater depths of the proximal part of a valley-filling pyroclastic flow (Fig. II.10; McArthur et al. 1998). Previously, (most possibly) the strong orientation of such rocks suggested the lava origin (flow foliation) for the professionals of the uranium ore exploration work. On the other hand, (2) detrital samples collected near Gyürüfü bear less significant orientation. Altered glass shards in these rocks could preserve their original X and Y shape. According to the form of the altered glass shards and the weak orientation of the rocks, they were not affected by welding (e.g., Gifkins et al. 2005a,b); thus, were interpreted as non-welded, crystal-rich, pumice-bearing lapilli tuffs, most possibly representing the upper, the lowermost, the sideward or the distal part of the aforementioned pyroclastic flow (Fig. II.10; McArthur et al. 1998).

At the northern foreland of the Villány Mts, the samples of the Peterd-1, the Vókány-2 and the Egerág-7 boreholes were also interpreted as lavas having flow foliation 


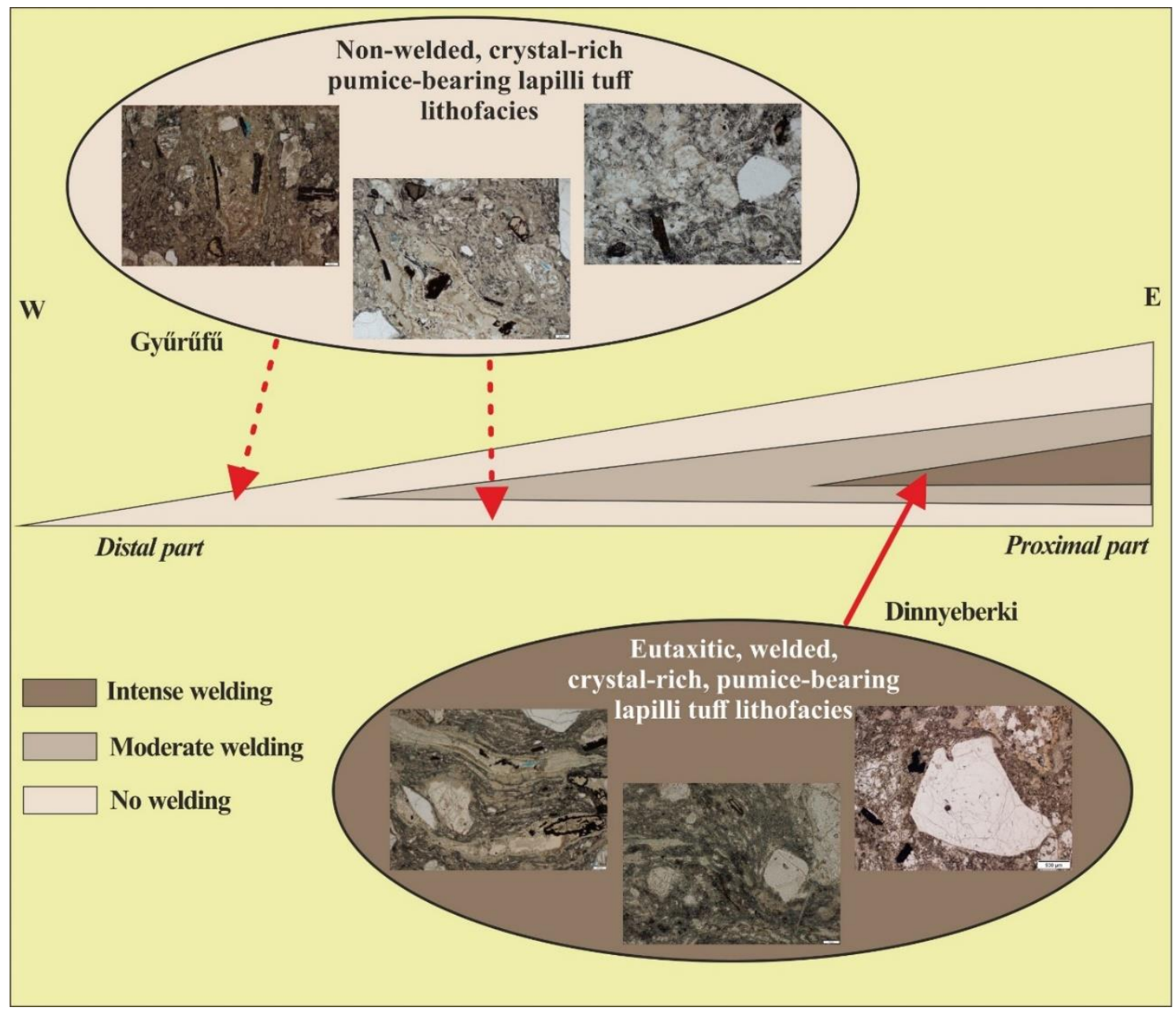

Figure II.10 The hypothetical position of the two distinct lithofacies in the Western Mecsek Mts, Gyürüfü area (outcrop) within the valley-filling pyroclastic flow (ideal section, based on McArthur et al. 1998)

structure defined by 'irregular, tortuous components' (Fazekas 1978; Konrád 1981; Barabásné Stuhl 1988). Petrographic observations showed that the latter are actually altered, devitrified pumices. Based on this and a wide range of other evidence, these samples proved to be pyroclastic rocks, as well. Coherent lava or felsitic textures in the archive reports actually refer to moderately welded rocks, while fluidal, 'poorlydifferentiated' felsitic sequences should represent the intensely welded parts. Although pyroclastic rocks were mentioned in the previous reports, too (e.g., Bisse-1 and Vókány2 boreholes: upper volcanic sequences), it was revealed that they are further more frequent among the Permian volcanic rocks of S Trandanubia.

Petrographic observations also revealed that the restricted amount of available drill cores and the altered, recrystallized, fragmented character of the samples do not make it possible to say whether they have subvolcanic and lava origin in case of some samples. The latter is in contradiction with the previous reports using quite explicit categories (e.g., volcanic vent facies, subvolcanic ‘microgranite porphyry'; Fazekas 1978; Barabásné 


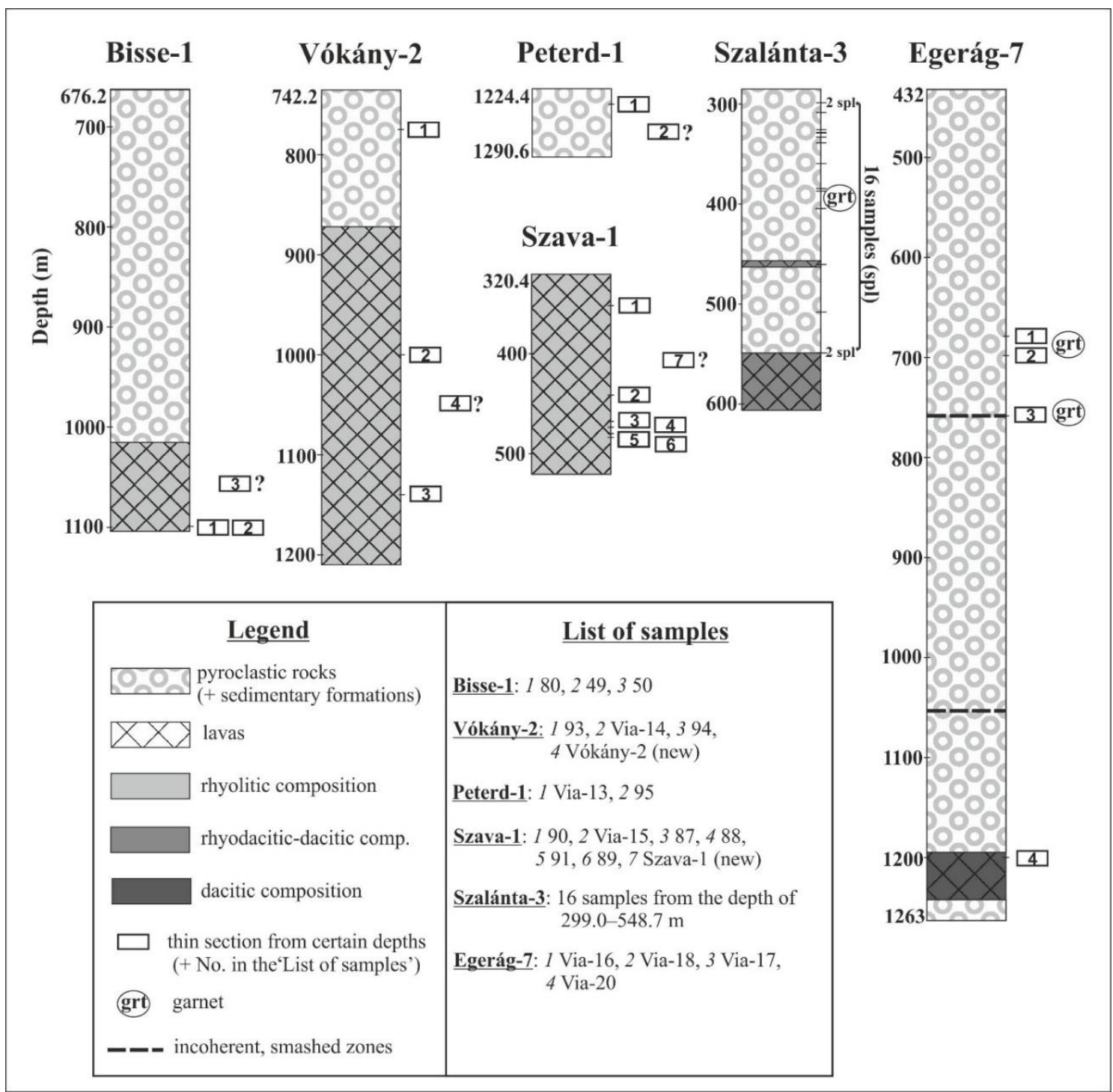

Figure II.11 Lithological columns of the Permian volcanic sequences at the northern foreland of the Villány Mts. Observed rocks (thin sections) are listed in the 'List of samples': samples of the 'Volcanites, etalon collection' were marked by numbers, while samples of the collection of the Eötvös Loránd University were marked by Via-X labels; in both cases the identifier numbers of the appropiate collections were used (see details in Supplementary Table II.1)

Stuhl 1988). Nevertheless, the fact that in the Bisse-1, the Vókány-2, the Egerág-7 and the Szalánta-3 boreholes, subvolcanic rocks or lavas are covered by pyroclastites (without any sedimentary rocks between them; Fig. II.11), as well as the spherulitic samples in the central part of the lower volcanic sequence of the Vókány-2 borehole and lower perlitic lithofacies of the Bisse-1 borehole suggest that the aforementioned rocks represent dominantly lava flows/domes. The basically great thickness of the lower lithology of the Vókány-2 well might refer to several flow/dome units as the average thickness of silicic lava flows is $\sim 20-300 \mathrm{~m}$ (Walker 1973). The latter is supported by the results of Szepesi (2009) and Szepesi and Kozák (2008), too, regarding Neogene silicic lava flows/domes (e.g., Kögát silicic lava structure, Tokaj Mts - maximum thickness: 207 m). However, in 
the South Permian Basin, Palaeozoic rhyodacitic lava units of 30-600 m were documented (Paulick and Breitkreuz 2005). Although the samples of the Szava-1 borehole were interpreted as subvolcanic rocks/dykes as 'microgranite porphyry' (Fazekas 1978; Barabásné Stuhl 1988), its brecciation at the margins and the carapace/core ratio (Paulick and Breitkreuz 2005) suggest that they could have been rhyolitic lava flows/domes, modified by tectonism (Fazekas 1978; Barabásné Stuhl 1988). In case of the Egerág-7 and Szalánta-3 boreholes, the repetition of each lithologies (pyroclastic and subvolcanic/lava; Fig. II.11) could be explained by distinct extrusions/intrusions or by tetonic repetition (reverse faults). The lack of sedimentary rocks between these lithologies refers to their lava origin. Tectonic repetition is supported by the presence of fault zones (Konrád 1981; Barabásné Stuhl 1988) in the Egerág-7 borehole.

Based on the observed lithologies (Fig. II.11 and Supplementary Table II.2), at the northern foreland of the Villány Mts an earlier effusive magmatism is supposed that was followed by explosive eruptions covering its products (lava flows/domes) and the palaeosurface (sedimentary formations) by thick ignimbrite sheets (up to hundred of metres). As the result of the former episode, in the Bisse-Vókány area, a rhyolitic lava dome/flow was formed, and the felsitic, spherulitic samples of the lower sequence of the Vókány-2 borehole might represent its central (or transitional) zone, while perlitic/pumiceous perlitic rocks of the Bisse-1 borehole could be derived from its brecciated, marginal zone (McPhie et al. 1993; Szepesi 2007; Szepesi and Kozák 2008). Another silicic lava flow/dome was penetrated by the Szava-1 borehole. Similarly to the Bisse-1 and the Vókány-2 boreholes, the lower, rhyodacitic/dacitic subvolcanic or lava lithologies of the neighbouring Egerág-7 and Szalánta-3 wells could be correlated with each other. All of these felsic volcanic centres were buried by a possibly regional ignimbrire sheet, exposed by the Peterd-1, the Vókány-2, the Egerág-7, the Szalánta-3 and the Bisse-1 boreholes (upper volcanic sequences). In the Egerág-7 borehole, based on the great thickness $(\geq 831 \mathrm{~m})$ of the volcanic rocks and the alternation of the strongly and the slightly welded parts, it is possible that multiple pyroclastic flows were penetrated. On the other hand, in this borehole steeply dipping $\left(70-80^{\circ}\right)$ altered pumices were documented (Konrád 1981; Barabásné Stuhl 1988), too, that might indicate tectonic tipping out.

Overall, the pyroclastic rocks of the nothern foreland of the Villány Mts show significant petrographic similarity to those of the Western Mecsek Mts, suggesting their 
common origin (see comparison in Supplementary Table II.2). According to the mineralogical composition, all of the pyroclastic rocks are rhyolites; however, petrographic observations and archive reports (e.g., Fazekas 1978) point to the alteration of feldspar crystals (albitization, K-metasomatism) making the petrography-based rock classification not completely reliable. Iridescent, pectinate K-feldspar (adularia) suggests K-metasomatism; adularization is a common alteration of glassy tuffs under arid conditions (Ennis et al. 2000; Rougvie and Sorensen 2002). The latter was also supported by the XRD analyses of separated feldspar crystals (adularia) in case of the outcrop rock samples. On the whole, it is feasible that primarily dacitic rocks were altered to rhyolitic as the result of such proccesses; however, it demands further whole-rock geochemical analyses. Dacitic composition is supported by the crystal-rich character of the samples and the altered pyroxene crystals occurring in them as rock-forming minerals. Crystalrich, voluminous and compositionally homogeneous dacitic ignimbrites are known as 'monotoneous intermediates' in the geological literature (Hildreth 1981). Formation of such rocks is explained by the rejuvenation of crystal mush in the middle to lower crustal reservoirs by magma injections and subsequent explosive eruptions (Bachmann and Bergantz 2004, 2008; Huber et al. 2012).

In order to obtain further petrogenetic and geochronological information about the rocks, accessory minerals play a keyrole. Zircon crystals were found in almost all of the samples, in the groundmass and as inclusions, as well (Supplementary Figure II.6/a, b). As reliable $\mathrm{U}-\mathrm{Pb}$ radiometric age data are lacking in case of the Permian felsic volcanic rocks of S Transdanubia, obtaining such information means the following part of the research. Further petrogenetic information could be gained by the compositional analyses (including major and trace elements) of the garnet crystals in the samples of the Egerág7 and the Szalánta-3 boreholes (Supplementary Figure II.6/c-f). Petrographic features suggest that these garnets have primary magmatic origin. Almandine composition determined by the previous SEM analyses (Jakab 2005), refers to the following crystallization circumstances: tensional stress field, rapid ascent in tectonically weak zones and a hydrous mantle source (Harangi et al. 2001).

In the area of the European Variscides (e.g., Intra-Sudetic Basin, South Permian Basin, Apuseni Mts, Central Western Carpathians) Permo-Carboniferous large-volume felsic volcanism often took place as a set of multiple distinct events (Awdankiewicz 1999; Awdankiewicz and Kryza 2010; Nicolae et al. 2014; Vozárová et al. 2015). Volcanicsedimentary sequences exposed in the aforementioned, analogous areas of $\mathrm{S}$ 
Transdanubia, are rich in various volcanic products (subvolcanic intrusions, lavas, pyroclastites), forms (laccoliths, dykes, calderas, ignimbrite sheets etc.) and associated compositions (basic to silicic). Contrarily, the Gyürüfü Rhyolite was previously supposed to be dominantly lava ('quartz-porphyry') as a Lower Permian marker horizon. Actually, this formation is more complex than it was previously thought, and taking into consideration the analogous rocks, it is feasible that it represents a long-lived (>10 Ma), complex volcanic system. In order to explore this system and to correlate the Gyürüfü Rhyolite, whole-rock geochemical analyses (major and trace elements) and zircon $\mathrm{U}-\mathrm{Pb}$ datings could mean the next steps. 


\section{CHAPTER III}

\section{LAVAS OR IGNIMBRITES? PERMIAN FELSIC VOLCANIC ROCKS OF THE TISZA MEGA-UNIT (SE HUNGARY) REVISITED: A PETROGRAPHIC STUDY}

\section{Máté Szemerédi}

Department of Mineralogy, Geochemistry and Petrology, 'Vulcano' Petrology and Geochemistry Research Group, University of Szeged, Szeged, Hungary; MTA-ELTE Volcanology Research Group, Budapest, Hungary email: h462582@stud.u-szeged.hu; szemeredi.mate@gmail.com

\section{Andrea Varga}

Department of Mineralogy, Geochemistry and Petrology, 'Vulcano' Petrology and Geochemistry Research Group, University of Szeged, Szeged, Hungary email: raucsikvarga@geo.u-szeged.hu

\section{János Szepesi}

MTA-ELTE Volcanology Research Group, Budapest, Hungary; Isotope Climatology and Environmental Research Centre (ICER), Institute of Nuclear Research, Hungarian Academy of Sciences, Debrecen, Hungary email: szepeja@gmail.com

\section{Elemér Pál-Molnár}

Department of Mineralogy, Geochemistry and Petrology, 'Vulcano' Petrology and Geochemistry Research Group, University of Szeged, Szeged, Hungary; MTA-ELTE Volcanology Research Group,

Budapest, Hungary email: palm@geo.u-szeged.hu

\section{Réka Lukács}

MTA-ELTE Volcanology Research Group, Budapest, Hungary; Department of Mineralogy, Geochemistry and Petrology, 'Vulcano' Petrology and Geochemistry Research Group, University of Szeged, Szeged, Hungary email: reka.harangi@gmail.com

Central European Geology

Manuscript accepted on December 28, 2019 


\title{
Lavas or ignimbrites? Permian felsic volcanic rocks of the Tisza Mega-unit (SE Hungary) revisited: A petrographic study
}

\author{
by: Máté Szemerédi, Andrea Varga, János Szepesi, Elemér Pál-Molnár and Réka \\ Lukács
}

\begin{abstract}
Permian felsic volcanic rocks encountered in petroleum exploration boreholes in SE Hungary (eastern Pannonian Basin, Tisza Mega-unit, Békés-Codru Unit) during the second half of the 20th century. They were considered to be predominantly lavas (the socalled "Battonya quartz-porphyry") and were genetically connected to the underlying "Battonya granite". New petrographic observations, however, showed that the presumed lavas are crystal-poor (8-20 vol\%) rhyolitic ignimbrites near Battonya and resedimented pyroclastic or volcanogenic sedimentary rocks in the Tótkomlós and the Biharugra areas, respectively. The studied ignimbrites are usually massive, matrix-supported, fiammebearing lapilli tuffs with eutaxitic texture as a result of welding processes. Some samples lack vitroclastic matrix and show low crystal breakage, but consist of oriented, devitrified fiammes, as well. Textural features suggest that the latter are high-grade rheomorphic ignimbrites.

Felsic volcanic rocks in SE Hungary belong to the Permian volcanic system of the Tisza Mega-unit; however, they show remarkable petrographic differences as compared to the other Permian felsic volcanic rocks of the mega-unit. In contrast to the crystalpoor rhyolitic ignimbrites of SE Hungary with rare biotite, the predominantly rhyodacitic-dacitic pyroclastic rocks of the Tisza Mega-unit are crystal-rich (40-45 vol\%) and often contain biotite, pyroxene and garnet. Additionally, some geochemical and geochronological differences between them were also observed by previous studies. Therefore, the Permian felsic volcanic rocks in SE Hungary might represent the most evolved, crystal-poor rhyolitic melt of a large-volume felsic (rhyodacitic-dacitic) volcanic system.

The Permian volcanic rocks of the studied area do not show any evident correlations with either the Permian felsic ignimbrites in the Finiş Nappe (Apuseni Mts, Romania), as was supposed so far, or the similar rocks in any nappe of the Codru Nappe System. Moreover, no relevant plutonic-volcanic connection was found between the studied samples and the underlying "Battonya granite".
\end{abstract}

\subsection{Introduction}

Permo-Carboniferous large-volume silicic magmatism is a common feature of the European Variscides that was genetically controlled by a post-collisional to extensional tectonic setting (Cortesogno et al. 1998; Awdankiewicz 1999; Wilson et al. 2004; Paulick and Breitkreuz 2005; Vozárová et al. 2009, 2015, 2016; Seghedi 2010; Wilcock et al. 2013; Letsch et al. 2014; Nicolae et al. 2014; Repstock et al. 2017; Ondrejka et al. 2018). Permian volcanic rocks associated with such magmatic activity are well-known in the Tisza Mega-unit (Tisza MU, Pannonian Basin; Fig. III.1/a) and exposed in several outcrops (Apuseni Mts, Romania and Western Mecsek Mts, Hungary) and by boreholes 
(S Transdanubia and the eastern Pannonian Basin, Hungary), representing all three Alpine facies zones of the Tisza MU (Mecsek, Villány-Bihor and Békés-Codru Units; Fig. III.1/b; Szederkényi 1962; Barabásné Stuhl 1988; Hidasi et al. 2015; Szemerédi et al. 2016, 2017, 2020a). Based on petrographic, whole-rock geochemical (including major and trace elements) and geochronological (zircon $\mathrm{U}-\mathrm{Pb}$ ages) results (see details in Chapter IV) all Permian felsic volcanic rocks within the Tisza MU are the products of the same volcanic epoch $(266.8 \pm 2.7-259.5 \pm 2.6 \mathrm{Ma}$; Szemerédi et al. 2020a).

Ancient volcanic rocks might have undergone various processes of syn- and postvolcanic alteration; thus, it could be a real challenge to determine their original volcanic facies. Primary textural features could have been overprinted or modified, making the genetic interpretation (e.g., pyroclastic rock or lava) of such rocks a difficult task for volcanologists (e.g., Allen 1988; Branney and Kokelaar 1992; Branney et al. 1992; Henry and Wolff 1992; Gifkins et al. 2005a,b). The incomplete destruction of primary textures and the different alteration styles can also have resulted in the development of false textures or pseudotextures. Thus, false pyroclastic textures (false shards, false eutaxitic texture) as well as false massive textures can have been formed, usually causing significant difficulties in the reliable interpretation of ancient volcanic rocks (Allen 1988; Gifkins et al. 2005a,b).

Permian felsic volcanic rocks of the Hungarian part of the Tisza MU were previously described and interpreted in the reports of uranium ore (S Transdanubia) and petroleum (SE Hungary) exploration work during the second half of the 20th centrury (e.g., Barabásné Stuhl 1988; Fülöp 1994; Körössy 2005a,b). According to the archive reports the rocks were considered to be dominantly lavas ("quartz-porphyry" using the appropriate paleovolcanic name; Szederkényi 1962; Szepesházy 1967; Barabásné Stuhl 1988; Körössy 2005a,b); however, modern petrographic observations (e.g., Hidasi et al. 2015; Szemerédi et al. 2016, 2017) reinterpreted most of them as ignimbrites in the area of S Transdanubia. In a similar way such a (re)examination of the Permian felsic volcanic rocks in SE Hungary was also required.

Three main subsurface areas of the Permian felsic volcanic rocks can be distinguised within S Transdanubia: (1) the Western Mecsek Mts, (2) the MáriakéméndBáta Basement Range (Máriakéménd-Báta BR) and (3) the northern foreland of the Villány Mts (Fig. III.1/a; Barabásné Stuhl 1988; Szemerédi et al. 2016, 2017). The Western Mecsek Mts and the Máriakéménd-Báta BR are represented by crystal-rich 


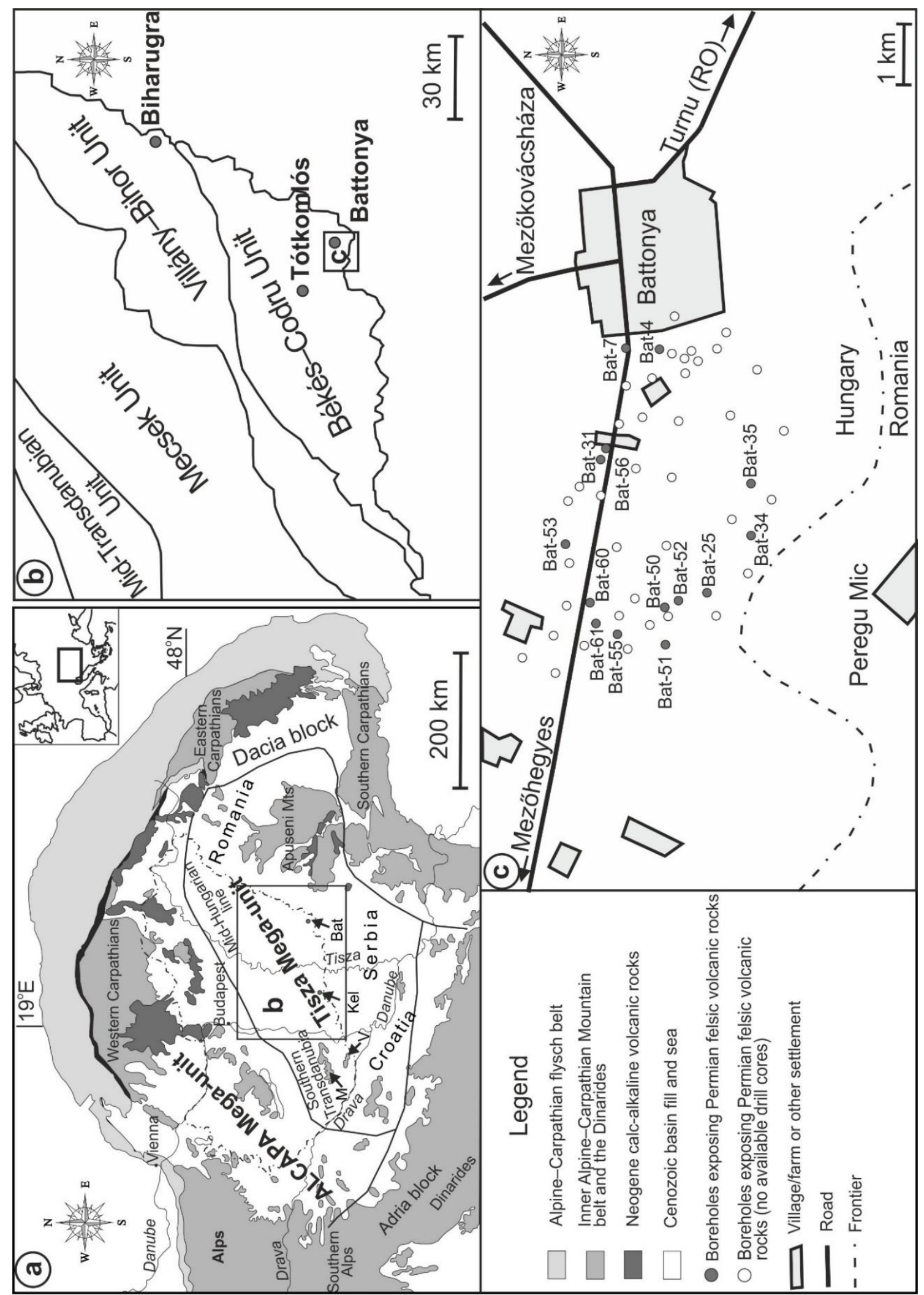

Figure III.1 Tectonic sketch of the Pannonian Basin, pointing out the surface and subsurface distribution of the Permian felsic volcanic rocks (a), highlighting the subsurface occurrences in SE Hungary (b), especially in the Battonya area (c). Map base is modified after Szemerédi et al. (2020a). Bat Battonya, Kel Kelebia, $M$ Mecsek Mts, $V$ Villány Mts 
fiamme-bearing rhyodacitic-dacitic ignimbrites, while in the northern foreland of the Villány Mts such ignimbrites and subordinate felsic lavas occur (Szemerédi et al. 2016, 2017, 2020a). In the Apuseni Mts (Fig. III.1/a; Codru and Biharia Nappe Systems), rhyodacitic-dacitic ignimbrites are present; however, they are accompanied by mafic-tointermediate lavas (basalt and subordinate andesite) as the result of a mainly bimodal volcanic activity (Codru Nappe System; Nicolae et al. 2014; Szemerédi et al. 2018a).

Detailed petrographic studies have not targeted the Permian felsic volcanic rocks of the eastern Pannonian Basin (Battonya-Pusztaföldvár Basement Ridge and Kelebia area, Hungary; Fig. III.1/a). These rocks were briefly described in the previous reports of hydrocarbon exploration (Szepesházy 1967; Körössy 2005a,b). Geochemically, all of the Permian felsic volcanic rocks in the Tisza MU show similar general characteristics (see details in Chapter IV). Nevertheless, some weak chemical differences were observed in the samples of the Battonya-Pusztaföldvár Basement Ridge (Battonya-Pusztaföldvár BR) that are rhyolites according to the immobile element-based rock classification $\left(\mathrm{Zr} / \mathrm{TiO}_{2}\right.$ vs. $\left.\mathrm{Nb} / \mathrm{Y}\right)$, while the others are rhyodacites-dacites (Szemerédi et al. 2020a). Moreover, felsic pyroclastic rocks in SE Hungary proved to be slightly younger than other Permian volcanic rocks of the Tisza MU (Szemerédi et al. 2020a).

The aim of this study is to provide a detailed petrographic description of the Permian felsic volcanic rocks of SE Hungary, using all available drill cores and thin sections from the boreholes near the villages of Battonya, Biharugra and Tótkomlós (Fig. III.1/b, c). Furthermore, we attempt to interpret the former and new descriptions in the light of modern volcanological views of the ancient, altered volcanic sequences (e.g., Gifkins et al. 2005a,b).

\subsection{Geologic background}

In SE Hungary, ca. 50 boreholes (near the villages of Battonya, Biharugra, Kelebia, Mezőkovácsháza, Nagyszénás, Pitvaros, Pusztaföldvár, Tótkomlós and Végegyháza) of hydrocarbon exploration work penetrated felsic volcanic rocks, predominantly within the Battonya-Pusztaföldvár BR (Fig. III.1/c and Fig. III.2; Szepesházy 1967; T. Kovács and Kurucz 1984; Császár 2005; Körössy 2005a,b). The highest density of drilling is represented by the $c a .60 \mathrm{~km}^{2}$ Battonya area (Fig. III.1/c) and most of the materials of the presented study derive from there (Szepesházy 1967; Császár 2005; Kőrössy 2005a). The Permian felsic volcanic rocks are collectively named the Gyürüfü Rhyolite Formation in 
the Hungarian lithostratigraphic literature and they form the regionally most widespread Permian formation (Fülöp 1994; Császár 2005; Szemerédi et al. 2020a). Stratigraphically, the basement of the volcanic rocks consists of Permian continental red beds (Korpád Sandstone Formation) but they are also often underlain by Variscan metamorphic rocks (two-mica schist and gneiss) or S-type granites ("Battonya granite”, Fig.III. 2; T. Kovács and Kurucz 1984; Fülöp 1994; Császár 2005; Körössy 2005a,b). The overlying formation is the Triassic Jakabhegy Sandstone; however, in most cases the volcanic rocks are covered by much younger Cenozoic sediments (e.g., Miocene sandstones). The Permian felsic volcanic rocks were penetrated in their greatest thickness in the Tótkomlós-I borehole ( 400 metres, Fig. III.2; Császár 2005; Körössy 2005a). According to the archive reports the felsic volcanic rocks in SE Hungary were described as "quartzporphyry" and predominantly interpreted as lavas or subvolcanic rocks with subordinate amounts of pyroclastics (Szepesházy 1967; Fülöp 1994; Császár 2005; Kőrössy 2005a,b).

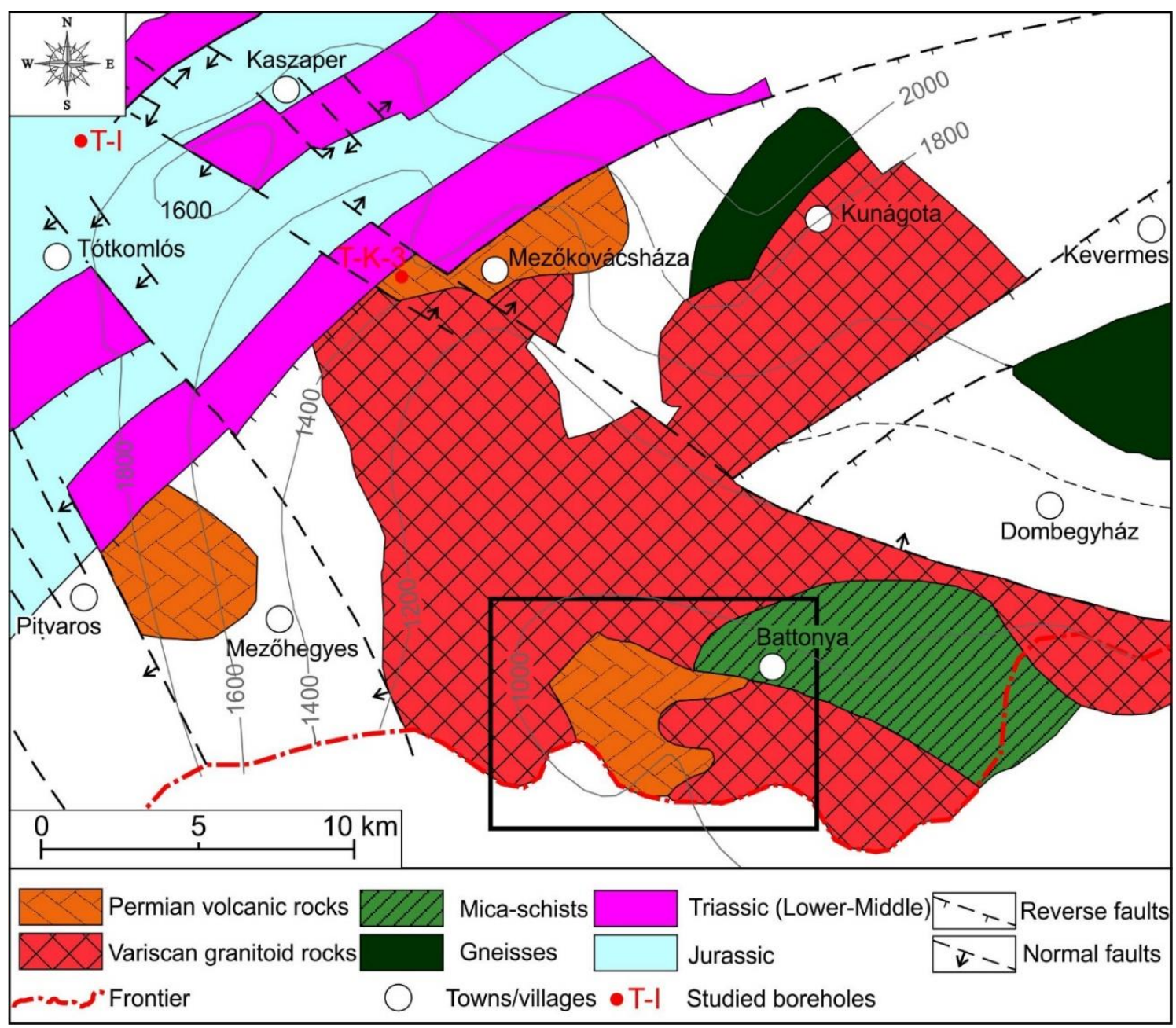

Figure III.2 Basement formations in the eastern Pannonian Basin (SE Hungary, Tisza Mega-unit, BékésCodru Unit), pointing out the most significant Battonya area (black rectangle) and two of the studied boreholes. T-I Tótkomlós-I, T-K-3 Tótkomlós-K-3 (modified after Kurucz 1977; T. Kovács and Kurucz 1984) 
A volcanic-plutonic connection was also supposed between the Permian volcanic rocks (thought to be dykes or lavas) and the underlying "Battonya granite" (thought to be Variscan) despite with the absence of any geochemical or geochronological evidence (Szepesházy 1967). Based on the strongly similar stratigraphical column of the Tótkomlós-I borehole (i.e., between 2,693 and 3,998 m beneath the surface: Mezosoic sedimentary rocks, Permian volcanic rocks and continental red beds, possible Precambrian granites; Körössy 2005a), the Battonya-Pusztafödvár BR was correlated with the Finiş Nappe of the Codru Nappe System (Codru NS), Apuseni Mts, Romania (Szepesházy 1979; Császár 2005; Kőrössy 2005a). Recently, however, Nicolae et al. (2014) documented crystal-rich, garnet-bearing pyroclastic rocks in the Finiş Nappe, that suggests differences when compared to the Permian volcanic rocks of the aforementioned areas.

\subsection{Materials and methods}

During the second half of the 20th century, hundreds of boreholes were drilled by the legal forerunner of the Hungarian Oil \& Gas Company Plc (MOL Rt.) in the eastern Pannonian Basin (Hungary) in order to explore hydrocarbon reservoirs (Szepesházy 1967; Császár 2005; Körössy 2005a,b). The drilling usually ended in Permian felsic volcanic rocks, representing the Palaeozoic basement of the Tisza MU (Fig. III.2). Drill cores from 17 boreholes (2-3 pieces/borehole) and 29 thin sections from three subsurface occurrences of the Permian felsic volcanic rocks, namely the Battonya, the Biharugra and the Tótkomlós areas, have been available for the present study at the Department of Mineralogy, Geochemistry and Petrology, University of Szeged (Table III.1; Fig. III.1/b). The most important data of the sampling sites and the investigated thin sections are summarized in Tables III.1 and III.2. The studied boreholes in the Battonya area are also highlighted in Fig. III.1/c.

Petrographic studies, including mineralogical and textural observations, were conducted on hand specimen and thin sections. In this study, modal compositions (vol\%) were generally estimated based on micropetrography. Nevertheless, modal (volume) proportions of rock-forming minerals, fragments, as well as groundmass were also measured quantitatively at least, on one selected representative sample of each distinct lithofacies, using a grid of 500 cells for each measurement (Table III.3). The terminology used in the petrographic descriptions and interpretations were derived from the following 
principal references: Branney and Kokelaar (1992), Branney et al. (1992), Henry and Wolff (1992), McPhie et al. (1993), Branney and Kokelaar (2002), Gifkins et al. (2005a,b), Paulick and Breitkreuz (2005), Brown et al. (2012) and Breitkreuz (2013). The most important terms used in the petrographic descriptions and interpretations as well as the abbreviations of each lithofacies name are summarized in Tables I.1 and III.2, respectively.

Table III.1 The most important data of the studied samples and boreholes in SE Hungary and the summary of the results of the archive reports and this study. Samples with available whole-rock (major and trace elements) geochemical data are put in italics and bold, while samples with zircon U-Pb ages are highlighted by asterisk (data in Szemerédi et al. 2020a; see details in Chapter IV). Lithofacies (Lf) description are listed in Table III.2

\begin{tabular}{|c|c|c|c|c|c|c|}
\hline \multirow{2}{*}{$\begin{array}{l}\text { Sample } \\
\text { code }\end{array}$} & \multirow{2}{*}{$\begin{array}{l}\text { Borehole } \\
\text { (core) }\end{array}$} & \multirow[t]{2}{*}{ Depth } & \multirow{2}{*}{$\begin{array}{l}\text { Total } \\
\text { depth }\end{array}$} & \multirow[t]{2}{*}{ Previous name } & \multicolumn{2}{|l|}{ This study } \\
\hline & & & & & Lithology & Lf \\
\hline $\begin{array}{l}\text { ÁGK- } \\
1790\end{array}$ & $\begin{array}{l}\text { Battonya-4 } \\
\text { (4) }\end{array}$ & $\begin{array}{l}1020.4-1025.5 \\
\mathrm{~m}\end{array}$ & $\begin{array}{l}1044.0 \\
\mathrm{~m}\end{array}$ & $\begin{array}{l}\text { felsitic quartz- } \\
\text { porphyry }\end{array}$ & pyroclastic & rheoLT \\
\hline $\begin{array}{l}\text { ÁGK- } \\
1790-2\end{array}$ & $\begin{array}{l}\text { Battonya-4 } \\
\text { (4) }\end{array}$ & $\begin{array}{l}1020.4-1025.5 \\
\mathrm{~m}\end{array}$ & $\begin{array}{l}1044.0 \\
\mathrm{~m}\end{array}$ & $\begin{array}{l}\text { felsitic quartz- } \\
\text { porphyry }\end{array}$ & pyroclastic & rheoLT \\
\hline $\begin{array}{l}\text { Bat-7 } \\
\text { (Via-79) }\end{array}$ & Battonya-7 & $\begin{array}{l}1058.0-1058.2 \\
\mathrm{~m}\end{array}$ & $\begin{array}{l}1060.0 \\
\mathrm{~m}\end{array}$ & quartz-porphyry & pyroclastic & accfrichT \\
\hline $\begin{array}{l}\text { ÁGK- } \\
1798 \\
\end{array}$ & $\begin{array}{l}\text { Battonya-25 } \\
(2)\end{array}$ & $\begin{array}{l}1026.0-1031.0 \\
\mathrm{~m}\end{array}$ & $\begin{array}{l}1042.0 \\
\mathrm{~m}\end{array}$ & $\begin{array}{l}\text { felsitic quartz- } \\
\text { porphyry }\end{array}$ & pyroclastic & rheoLT \\
\hline $\begin{array}{l}\text { ÁGK- } \\
1799\end{array}$ & $\begin{array}{l}\text { Battonya-25 } \\
\text { (3) }\end{array}$ & $\begin{array}{l}1031.0-1034.0 \\
\mathrm{~m}\end{array}$ & $\begin{array}{l}1042.0 \\
\mathrm{~m}\end{array}$ & $\begin{array}{l}\text { felsitic quartz- } \\
\text { porphyry }\end{array}$ & pyroclastic & rheoLT \\
\hline $\begin{array}{l}\text { ÁGK- } \\
1802\end{array}$ & $\begin{array}{l}\text { Battonya-31 } \\
\text { (3) }\end{array}$ & $\begin{array}{l}1029.5-1031.0 \\
\mathrm{~m}\end{array}$ & $\begin{array}{l}1044.0 \\
\mathrm{~m}\end{array}$ & $\begin{array}{l}\text { felsitic quartz- } \\
\text { porphyry }\end{array}$ & pyroclastic & rheoLT \\
\hline $\begin{array}{l}\text { ÁGK- } \\
1243\end{array}$ & Battonya-34 & $\begin{array}{l}1029.0-1030.5 \\
\mathrm{~m}\end{array}$ & $\begin{array}{l}1042.0 \\
\mathrm{~m}\end{array}$ & quartz-porphyry & pyroclastic & rheoLT \\
\hline $\begin{array}{l}\text { ÁGK- } \\
1271\end{array}$ & $\begin{array}{l}\text { Battonya-35 } \\
\text { (6) }\end{array}$ & $\begin{array}{l}1058.0-1062.0 \\
\mathrm{~m}\end{array}$ & $\begin{array}{l}1066.0 \\
\mathrm{~m}\end{array}$ & felsite & pyroclastic & emLT \\
\hline $\begin{array}{l}\text { ÁGK- } \\
1818\end{array}$ & $\begin{array}{l}\text { Battonya-50 } \\
\text { (1) }\end{array}$ & $\begin{array}{l}1020.0-1023.0 \\
\mathrm{~m}\end{array}$ & $\begin{array}{l}1053.0 \\
\mathrm{~m}\end{array}$ & felsite & pyroclastic & emLT \\
\hline $\begin{array}{l}\text { ÁGK- } \\
1274 \\
\end{array}$ & $\begin{array}{l}\text { Battonya-50 } \\
(2)\end{array}$ & $1053.0 \mathrm{~m}$ & $\begin{array}{l}1053.0 \\
\mathrm{~m}\end{array}$ & quartz-porphyry & pyroclastic & rheoLT \\
\hline $\begin{array}{l}\text { ÁGK- } \\
1819\end{array}$ & $\begin{array}{l}\text { Battonya-51 } \\
\text { (2) }\end{array}$ & $\begin{array}{l}1023.0-1024.5 \\
\mathrm{~m}\end{array}$ & $\begin{array}{l}1050.0 \\
\mathrm{~m}\end{array}$ & felsite & pyroclastic & emLT \\
\hline $\begin{array}{l}\text { ÁGK- } \\
1821\end{array}$ & $\begin{array}{l}\text { Battonya-51 } \\
\text { (4) }\end{array}$ & $\begin{array}{l}1027.2-1028.0 \\
\mathrm{~m}\end{array}$ & $\begin{array}{l}1050.0 \\
\mathrm{~m}\end{array}$ & felsite & pyroclastic & emLT \\
\hline ÁGK-1823 & $\begin{array}{l}\text { Battonya-52 } \\
\text { (1) }\end{array}$ & $\begin{array}{l}1022.0-1024.0 \\
\mathrm{~m}\end{array}$ & $\begin{array}{l}1050.0 \\
\mathrm{~m}\end{array}$ & $\begin{array}{l}\text { felsitic quartz- } \\
\text { porphyry }\end{array}$ & pyroclastic & rheoLT \\
\hline ÁGK-1824 & $\begin{array}{l}\text { Battonya-52 } \\
\text { (2) }\end{array}$ & $\begin{array}{l}1032.0-1033.5 \\
\mathrm{~m}\end{array}$ & $\begin{array}{l}1050.0 \\
\mathrm{~m}\end{array}$ & $\begin{array}{l}\text { felsitic quartz- } \\
\text { porphyry }\end{array}$ & pyroclastic & rheoLT \\
\hline $\begin{array}{l}\text { ÁGK- } \\
1825 \\
\end{array}$ & $\begin{array}{l}\text { Battonya-53 } \\
(2)\end{array}$ & $\begin{array}{l}1028.6-1033.0 \\
\mathrm{~m}\end{array}$ & $\begin{array}{l}1050.0 \\
\mathrm{~m}\end{array}$ & quartz-porphyry & pyroclastic & rheoLT \\
\hline $\begin{array}{l}\text { ÁGK- } \\
1828-1\end{array}$ & $\begin{array}{l}\text { Battonya-55 } \\
\text { (2) }\end{array}$ & $\begin{array}{l}1025.0-1028.0 \\
\mathrm{~m}\end{array}$ & $\begin{array}{l}1050.0 \\
\mathrm{~m}\end{array}$ & quartz-porphyry & pyroclastic & rheoLT \\
\hline $\begin{array}{l}\text { ÁGK- } \\
1828-2\end{array}$ & $\begin{array}{l}\text { Battonya-55 } \\
\text { (2) }\end{array}$ & $\begin{array}{l}1025.0-1028.0 \\
\mathrm{~m}\end{array}$ & $\begin{array}{l}1050.0 \\
\mathrm{~m}\end{array}$ & quartz-porphyry & pyroclastic & rheoLT \\
\hline ÁGK-1830 & $\begin{array}{l}\text { Battonya-56 } \\
\text { (3) }\end{array}$ & $\begin{array}{l}1033.5-1034.5 \\
\mathrm{~m}\end{array}$ & $\begin{array}{l}1045.0 \\
\mathrm{~m}\end{array}$ & quartz-porphyry & pyroclastic & emLT \\
\hline $\begin{array}{l}\text { ÁGK- } \\
1831 \\
\end{array}$ & $\begin{array}{l}\text { Battonya-60 } \\
(2)\end{array}$ & $\begin{array}{l}1025.0-1027.0 \\
\mathrm{~m}\end{array}$ & $\begin{array}{l}1045.0 \\
\mathrm{~m}\end{array}$ & felsite & pyroclastic & emLT \\
\hline $\begin{array}{l}\text { ÁGK- } \\
1833 \\
\end{array}$ & $\begin{array}{l}\text { Battonya-61 } \\
\text { (3) }\end{array}$ & $\begin{array}{l}1028.0-1031.0 \\
\mathrm{~m}\end{array}$ & $\begin{array}{l}1053.0 \\
\mathrm{~m}\end{array}$ & quartz-porphyry & pyroclastic & rheoLT \\
\hline $\begin{array}{l}\text { ÁGK- } \\
1339\end{array}$ & $\begin{array}{l}\text { Biharugra-I } \\
(20)\end{array}$ & $\begin{array}{l}3157.0-3158.0 \\
\mathrm{~m}\end{array}$ & $\begin{array}{l}3200.0 \\
\mathrm{~m}\end{array}$ & quartz-porphyry & pyroclastic & $\operatorname{lmLT}$ \\
\hline
\end{tabular}


Table III.1 continued

\begin{tabular}{|c|c|c|c|c|c|c|}
\hline \multirow{2}{*}{$\begin{array}{l}\text { Sample } \\
\text { code }\end{array}$} & \multirow{2}{*}{$\begin{array}{l}\text { Borehole } \\
\text { (core) }\end{array}$} & \multirow[t]{2}{*}{ Depth } & \multirow{2}{*}{$\begin{array}{l}\text { Total } \\
\text { depth }\end{array}$} & \multirow[t]{2}{*}{ Previous name } & \multicolumn{2}{|l|}{ This study } \\
\hline & & & & & Lithology & Lf \\
\hline $\begin{array}{l}\text { ÁGK- } \\
1340\end{array}$ & $\begin{array}{l}\text { Biharugra-I } \\
\text { (21) }\end{array}$ & $\begin{array}{l}3198.0-3198.5 \\
\mathrm{~m}\end{array}$ & $\begin{array}{l}3200.0 \\
\mathrm{~m}\end{array}$ & ignimbrite & pyroclastic & $\operatorname{lmLT}$ \\
\hline $\begin{array}{l}\text { ÁGK- } \\
1340-2\end{array}$ & $\begin{array}{l}\text { Biharugra-I } \\
\text { (21) }\end{array}$ & $\begin{array}{l}3198.0-3198.5 \\
\mathrm{~m}\end{array}$ & $\begin{array}{l}3200.0 \\
\mathrm{~m}\end{array}$ & ignimbrite & pyroclastic & $\operatorname{lmLT}$ \\
\hline BATR/1* & $\begin{array}{l}\text { Tótkomlós-K- } \\
3\end{array}$ & $\begin{array}{l}1669.0-1674.0 \\
\mathrm{~m}\end{array}$ & $\begin{array}{l}1686.0 \\
\mathrm{~m}\end{array}$ & quartz-porphyry & pyroclastic & $\operatorname{lmLT}$ \\
\hline$B A T R / 2 *$ & $\begin{array}{l}\text { Tótkomlós-K- } \\
3\end{array}$ & $\begin{array}{l}1669.0-1674.0 \\
\mathrm{~m}\end{array}$ & $\begin{array}{l}1686.0 \\
\mathrm{~m}\end{array}$ & quartz-porphyry & pyroclastic & $\operatorname{lmLT}$ \\
\hline $\begin{array}{l}\text { ÁGK- } \\
1267\end{array}$ & $\begin{array}{l}\text { Tótkomlós-K- } \\
3 \text { (17) }\end{array}$ & $\begin{array}{l}1669.0-1674.0 \\
\mathrm{~m}\end{array}$ & $\begin{array}{l}1686.0 \\
\mathrm{~m}\end{array}$ & quartz-porphyry & pyroclastic & $\operatorname{lmLT}$ \\
\hline T-I $13 \mathrm{MF}$ & $\begin{array}{l}\text { Tótkomlós-I } \\
\text { (13) }\end{array}$ & $\begin{array}{l}3248.0-3249.0 \\
\mathrm{~m}\end{array}$ & $\begin{array}{l}3998.0 \\
\mathrm{~m}\end{array}$ & quartz-porphyry & $\begin{array}{l}\text { pyroclastic } \\
\text { or lava }\end{array}$ & $\begin{array}{l}\text { vlava- } \\
\text { likeT }\end{array}$ \\
\hline T-I $14 \mathrm{MF}$ & $\begin{array}{l}\text { Tótkomlós-I } \\
\text { (14) }\end{array}$ & $\begin{array}{l}3267.0-3268.0 \\
\mathrm{~m}\end{array}$ & $\begin{array}{l}3998.0 \\
\mathrm{~m}\end{array}$ & quartz-porphyry & $\begin{array}{l}\text { pyroclastic } \\
\text { or lava }\end{array}$ & $\begin{array}{l}\text { vlava- } \\
\text { likeT }\end{array}$ \\
\hline T-I $15 \mathrm{MF}$ & $\begin{array}{l}\text { Tótkomlós-I } \\
\text { (15) }\end{array}$ & $\begin{array}{l}3402.0-3404.0 \\
\mathrm{~m}\end{array}$ & $\begin{array}{l}3998.0 \\
\mathrm{~m}\end{array}$ & quartz-porphyry & $\begin{array}{l}\text { pyroclastic } \\
\text { or lava }\end{array}$ & $\begin{array}{l}\text { vlava- } \\
\text { likeT }\end{array}$ \\
\hline
\end{tabular}

\subsection{Results}

Based on the petrographic observations, five distinct lithofacies can be distinguished among the volcanic rock samples (Table III.2) which are separately described and interepreted below.

Table III.2 Terminology used for the characterization of the lithofacies of the Permian felsic volcanic rocks in SE Hungary (modified after Branney and Kokelaar 2002; Sommer et al. 2013)

\begin{tabular}{ll}
\hline Facies code & Lithofacies description \\
\hline emLT & Eutaxitic, massive, matrix-supported, porphyric, fiamme-bearing lapilli tuffs \\
rheoLT & Felsitic, matrix-supported, porphyric, fiamme-bearing rheomorphic lapilli tuffs \\
accfrichT & Matrix-supported, fine-grained, felsitic ash tuff with coated particles \\
lmLT & Lithic-rich, massive, strongly sericitized, poorly-sorted volcaniclastics \\
vlava-likeT & Spherulitic, vitrophyric lava-like ash tuffs \\
\hline
\end{tabular}

Table III.3 Modal (volume) proportions (in \%) of rock-forming minerals, fiammes, as well as the groundmass, measured quantitatively at least. on one selected representative sample of each distinct lithofacies. The meaning of the abbreviations applied for the lithofacies (facies code) are described in Table III.2. $b t$ biotite, $c p$ coated particle, $f$ fiamme, $g$ groundmass, $k f s$ K-feldspar, $L_{v}$ volcanic lithic clast, $L_{n v}$ non-volcanic lithic clast, $p l$ plagioclase, qz quartz. *In case of lithic-rich, massive, strongly sericitized, poorly-sorted volcaniclastics strongly sericitized groundmass and altered juvenile fragments (fiammes and glass shards) were indistinguishable and given together as groundmass

\begin{tabular}{lllllllllll}
\hline Sample & Lithofacies & $\mathrm{qz}$ & $\mathrm{kfs}$ & $\mathrm{pl}$ & $\mathrm{bt}$ & $\mathrm{f}$ & $\mathrm{g}$ & $\mathrm{L}_{\mathrm{v}}$ & $\mathrm{L}_{\mathrm{nv}}$ & $\mathrm{cp}$ \\
\hline ÁGK-1821 & emLT & 3.5 & 3 & 1.8 & 0 & 11.5 & 80.2 & 0 & 0 & 0 \\
ÁGK-1830 & emLT & 7.5 & 4.9 & 5 & 0.1 & 9.6 & 72.9 & 0 & 0 & 0 \\
ÁGK-1828-2 & rheoLT & 12 & 4.6 & 3.1 & 0 & 9.9 & 70.4 & 0 & 0 & 0 \\
Bat-7 (Via- & accfrichT & 2.1 & 7.9 & 0 & 0 & 0 & 89.0 & 0 & 0 & 1.0 \\
79) & & & & & & & & & & \\
ÁGK-1340 & lmLT & 8.3 & 4 & 1.8 & 0.1 & $*$ & 69.3 & 14.5 & 0 & 0 \\
BATR/1 & lmLT & 9.3 & 1.3 & 0.7 & 0 & $*$ & 76.4 & 8.2 & 4.1 & 0 \\
T-I 14 MF & vlava-likeT & 5.5 & 4.1 & 0.4 & 0 & 0 & 90.2 & 0 & 0 & 0 \\
\hline
\end{tabular}




\subsubsection{Eutaxitic, massive, matrix-supported, porphyric, fiamme-bearing lapilli tuffs (emLT)}

The presence of the emLT lithofacies was demonstrated in five boreholes in the study area, namely wells Battonya-35, Battonya-50, Battonya-51, Battonya-56 and Battonya-60 (see details in Table III.1) in the Battonya-Pusztaföldvár BR, Békés-Codru Unit (Fig. III.1/c).

\section{Description}

Felsic rocks are purplish or greenish gray in color, and can be classified as massive, nonporous, matrix-supported lapilli tuffs that consist of macroscopically dark, flattened, devitrified fiammes (10-12 vol\%), usually $\mathrm{mm}$ in size, together with various poorlysorted and fragmented phenocrysts $(8-18 \mathrm{vol} \%)$ in a fine groundmass of predominantly quartz and feldspar (73-80 vol\%).

Well-visible oriented texture (Fig. III.3) is defined by deformed, devitrified glass shards (from $\sim 100 \mu \mathrm{m}$ up to the size of the fiammes; Fig. III.3/a, c) and devitrified fiammes (from several $\mathrm{mm}$ in size up to $1.5-2.5 \mathrm{~cm}$; Fig. III.3/b, e, f). In the fiamme rims, axiolites are common, whereas rare spherulites occur inside it (Fig. III.3/f). Fiammes and altered glass shards in the fine groundmass are replaced by mosaic quartz and feldspar (Fig. III.3/b, e). Inside the larger fiammes quartz and feldspar crystals (from 200 to 300 $\mu \mathrm{m}$ up to $1 \mathrm{~mm}$ ) and secondary minerals (e.g., carbonate, sericite and opaque minerals) are also present.

The major mineral assemblage consists of predominantly subhedral, rarely euhedral quartz (42-43 vol\%) and K-feldspar (28-36 vol\%), together with plagioclase (22-27 vol\%) and very rare biotite as a mafic component (<1 vol\%). Quartz crystals (up to $3 \mathrm{~mm}$ ) are usually resorbed (Fig. III.3/a, c, e), but rarely euhedral (Fig. III.3/d) phenocrysts with straight extinction; smaller crystalloclasts (broken, shard-like crystals) also appear. It is important to note that some large quartz crystals show a characteristic deformation feature (i.e., deformation lamellae; Fig. III.3/d). K-feldspar crystals (up to 5 $\mathrm{mm}$ ) are usually resorbed, fragmented and moderately altered (sericitized, carbonatized; Fig. III.3/a, e), showing Carlsbad twinning. Some K-feldspar with overgrowth (Kfeldpars as well) on their resorbed margin are also present. Polysynthetic twinned euhedral or subhedral plagioclase (Fig. III.3/e) crystals (up to $2 \mathrm{~mm}$ ) as well as opaque pseudomorphs of euhedral biotite crystals (up to $\sim 600 \mu \mathrm{m}$ ) are less common. As an 
accessory component, small $(<100 \mu \mathrm{m})$ subhedral or euhedral zircon crystals occur in the fine groundmass. Some samples from the Battonya-60 borehole are strongly brecciated that destroyed the primary texture (Fig. III.3/f).
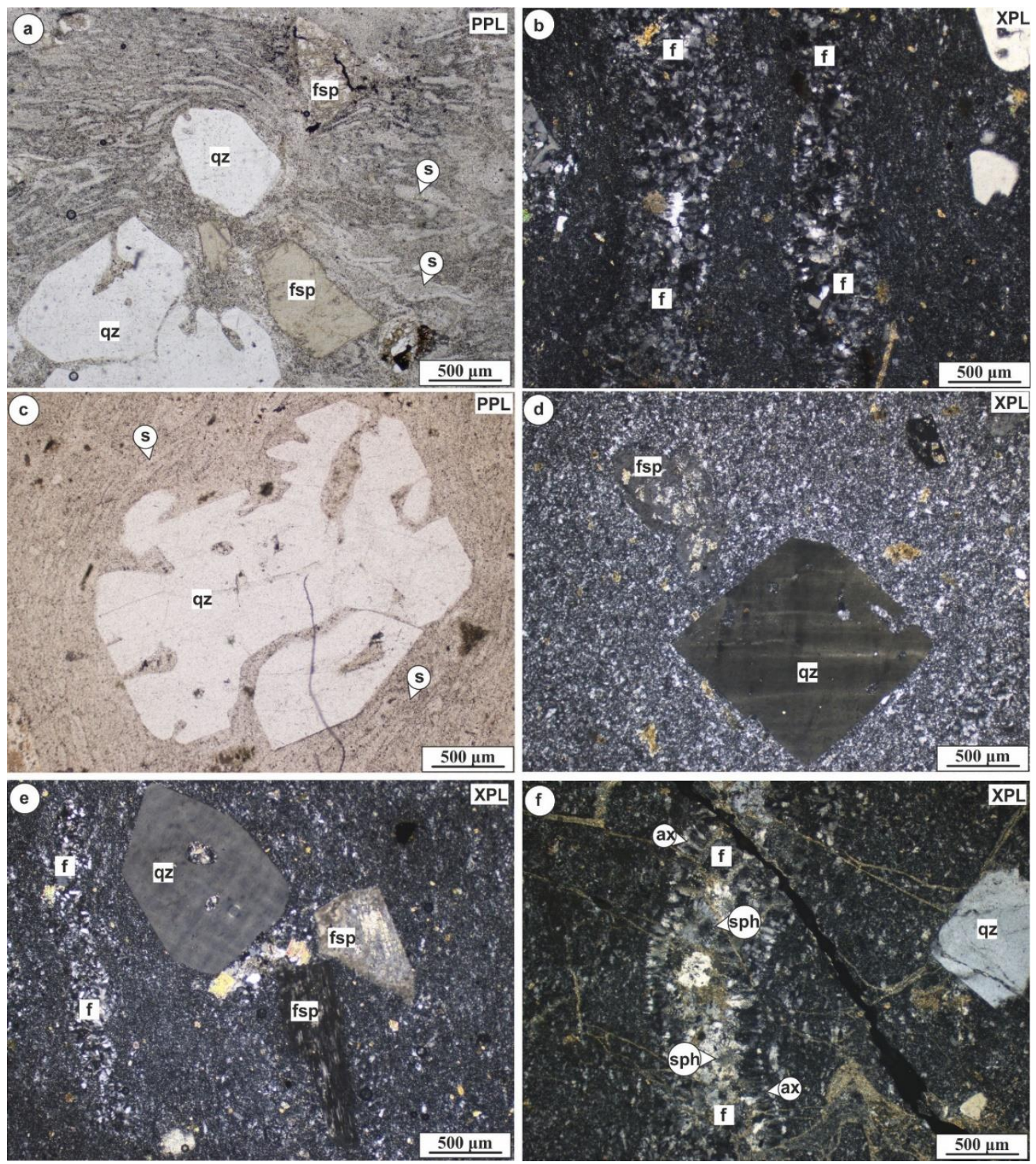

Figure III.3 Photomicrographs of the eutaxitic, massive, matrix-supported, porphyric, fiamme-bearing lapilli tuffs (emLT), Battonya area. a Sample ÁGK-1830, eutaxitic texture defined by deformed, elongated glass shards with subhedral quartz and feldspar phenocrysts; b Sample ÁGK-1830, oriented, devitrified fiammes replaced by mosaic of quartz and feldspar microcrysts; c Sample ÁGK-1821, subhedral, resorbed, porphyric quartz surrounded by deformed glass shards; d Sample ÁGK-1821, subhedral quartz crystal with deformation lamellae; e Sample ÁGK-1830, subhedral, resorbed quartz, Kfeldspar (above) and plagioclase (below) phenocrysts and devitrified fiamme replaced by mosaic of quartz and feldspar; f Sample ÁGK-1831, devitrified fiamme with axiolites at the rims and spherulites inside it, in a brecciated sample. $a x$ axiolite, $f$ altered fiamme, $f s p$ feldspar, $q z$ quartz, $s$ altered glass shard, sph spherulite, PPL plane polarized light, XPL crossed polars 


\section{Interpretation}

The major mineral assemblage (predominantly quartz and K-feldspar, less plagioclase and rare biotite) of the rocks suggests a rhyolitic composition. The unsorted massive appearance points to a pyroclastic flow (ignimbrite) origin. Oriented, eutaxitic texture indicates high-temperature plastic deformation of the vitroclasts (both pumice and glass shards; e.g., Gifkins et al. 2005a,b). Strong devitrification affected the juvenile fragments, creating high temperature crystallization domains (HTCDs; Breitkreuz 2013). This effect is demonstrated by spherulites inside the fiammes and axiolites at their rims (Fig. III.3/f). Additionally, incipient to strong welding is indicated by the flattened fiammes and sintering glass shards that determines the observed orientation of the rocks (e.g., Gifkins et al. 2005a,b; Fig. III.3/a, b), corresponding to the eutaxitic texture mentioned above. Purplish gray color of the macroscopic samples indicates the oxidation of the Fe-phases at high temperature during welding, while the greenish tones refer to different degrees of subsequent mineralization (e.g., the formation of celadonite and/or chlorite during secondary alteration processes).

\subsubsection{Felsitic, matrix-supported, porphyric, fiamme-bearing rheomorphic lapilli tuffs (rheoLT)}

The presence of the rheoLT lithofacies was demonstrated in eight boreholes in the study area, namely wells Battonya-4, Battonya-25, Battonya-31, Battonya-34, Battonya-52, Battonya-53, Battonya-55 and Battonya-61 (see details in Table III.1) in the BattonyaPusztaföldvár BR, Békés-Codru Unit (Fig. III.1/c).

\section{Description}

The samples of this group are purplish or greenish gray in color, and can be classified as massive non-porous matrix-supported felsic volcanic rocks, having a similar mineralogical composition (20 vol\% phenocryst content: $61 \%$ quartz, $23 \% \mathrm{~K}$-feldspar and $16 \%$ plagioclase) with the emLT lithofacies (Fig. III.3). Crystalloclasts are less common compared to the former lithofacies. The groundmass (70 vol\%) predominantly contains fine-grained homogeneous mosaics of quartz, feldspar and sericite (Fig. III.4/ac). However, in some parts (e.g., around coarser phenocrysts or separately in the matrix), mm-sized oriented patches (10 vol\%, up to 2-2.5 mm) of coarser $(150-200 \mu \mathrm{m})$ groundmass crystals with the same composition, showing no definite, sharp edge and 


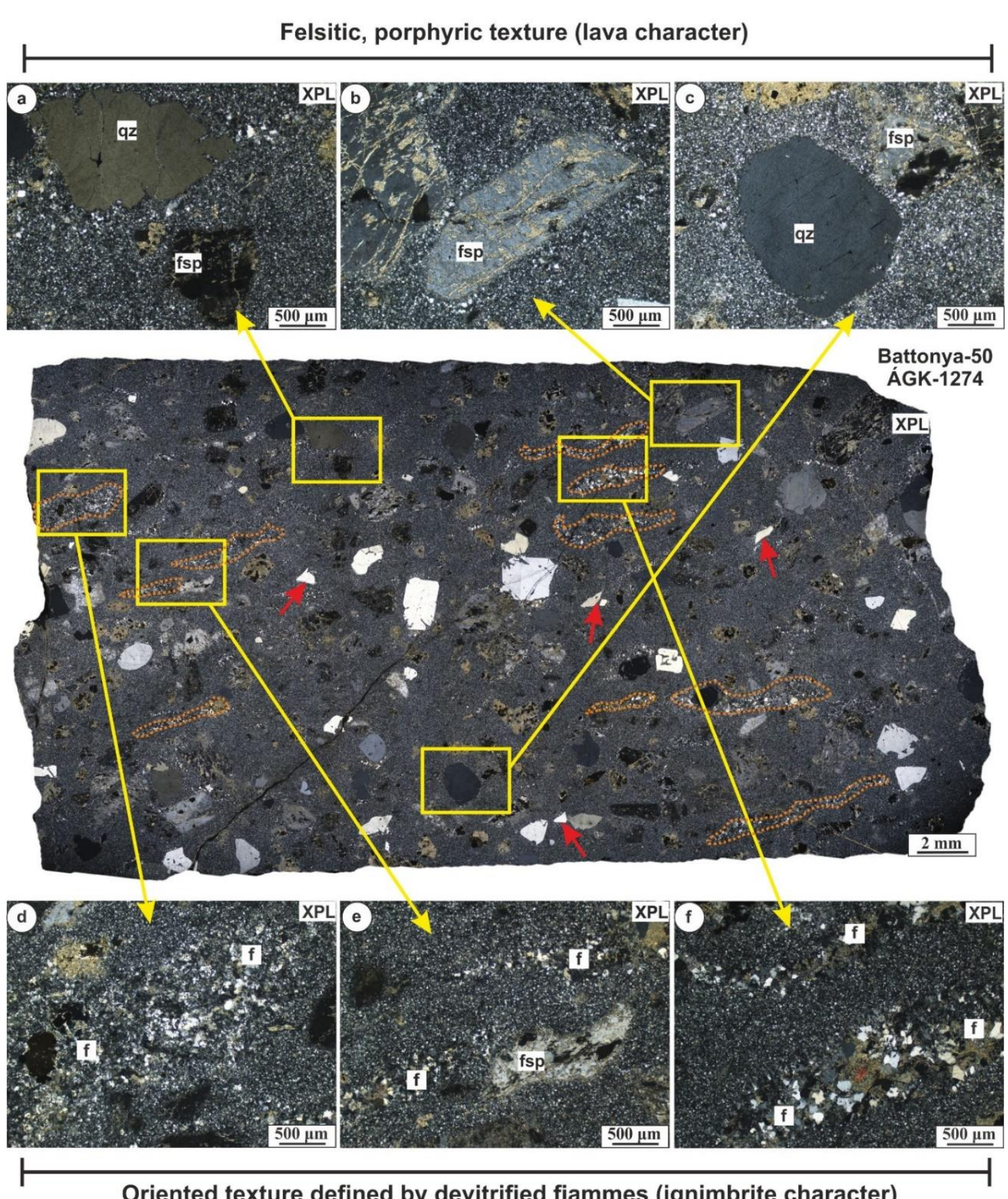

Figure III.4 Photomicrographs of the felsitic, matrix-supported, porphyric, fiamme-bearing rheomorphic lapilli tuffs (rheoLT), Battonya area, sample ÁGK-1274 (Battonya-50 borehole), highlighting apparent coherent texture (a-c) and oriented (eutaxitic) parts $(\mathbf{d}-\mathbf{f})$ of the sample. a-c Homogeneous groundmass with mosaics of quartz and feldspar microcrysts (crystalloclasts and devitrified glass shards) and subhedral, resorbed phenocrysts; $\mathbf{d}-\mathbf{f}$ Remnants of oriented fiammes referring to rheomorphic flow that postdate or might have occurred during the ignimbrite emplacement and deposition. Note: significant differences in the size of the phenocrysts and the presence of some angular, broken crystals (crystalloclasts pointed by red arrows). $f$ altered fiamme, $f s p$ feldspar, $q z$ quartz, $X P L$ crossed polars rarely spherulites inside them, do occur (Fig. III.4/d-f). The mentioned patches (Fig. III.4/d-f) of predominantly quartz and feldspar bear well-visible orientation that could barely be observed macroscopically but always in thin sections in crossed polars (Fig. III.4). On the other hand, such an orientation could be observed neither in the fine-grained 
part of the groundmass (Fig. III.4/a-c) nor in plane polarized light in the whole material. According to the observed features, these rocks have a predominantly felsitic, porphyric texture (Fig. III.4/a-c); however, the oriented patches of coarser groundmass crystals, resembling to altered fiammes, show eutaxitic characteristics (Fig. III.4/e, f). These two distinct textural features can be commonly observed in one thin section next to each other as is displayed by a representative sample in Figure III.4.

\section{Interpretation}

The major mineral assemblage with predominant quartz and K-feldspar phenocrysts suggests the same rhyolitic composition. However, the genetic interpretation (pyroclastic rocks or lavas) of the samples is rather difficult. Parts showing felsitic, porphyric texture with homogeneous groundmass and resorbed, large phenocrysts resemble silicic lavas, apparently suggesting a coherent lava facies origin (McPhie et al. 1993; Fig. III.4/a-c). However, the mm-sized oriented patches of coarser (150-200 $\mu \mathrm{m})$ quartz, feldspar and sericite crystals in the groundmass with no definite, sharp edge (Fig. III.4/d-f) could be interpreted as the remnants of devitrified fiammes. Based on the observed features, including the lack of vitroclastic texture and lithic clasts, low crystal breakage, but the presence of lineations (devitrified fiammes), the most feasible is that these samples are high-grade rheomorphic ignimbrites (Branney and Kokelaar 1992; Branney et al. 1992; Henry and Wolff 1992). As the result of rheomorphism and/or devitrification, vitroclastic features (i.e., well-visible altered glass shards in the groundmass) are lacking; however, the orientation of the flattened devitrified fiammes (Fig. III.4) refers to a rheomorphic flow that postdate or might have occurred during the ignimbrite emplacement and deposition (Branney et al. 1992; Henry and Wolff 1992). Each step of the spectrum can be seen in Figure III.5 from eutaxitic welded ignimbrites (emLT lithofacies), having vitroclastic texture with evident altered fiammes and glass shards (Fig. III.5/a, b) to highgrade rheomorphic ignimbrites (Fig. III.5/c-f) with barely recognizable remnants of fiammes. Thus, the samples of the rheoLT lithofacies could represent the same ignimbrite sheet as the $e m L T$ lithofacies; however, they were formed along slightly different (i.e., higher) temperature and compositional circumstances, e.g., lower volatile content, minimizing the amount of vesiculation, resulting in low explosivity of the eruptions (low crystal breakage) in the Battonya area (Henry and Wolff 1992). 

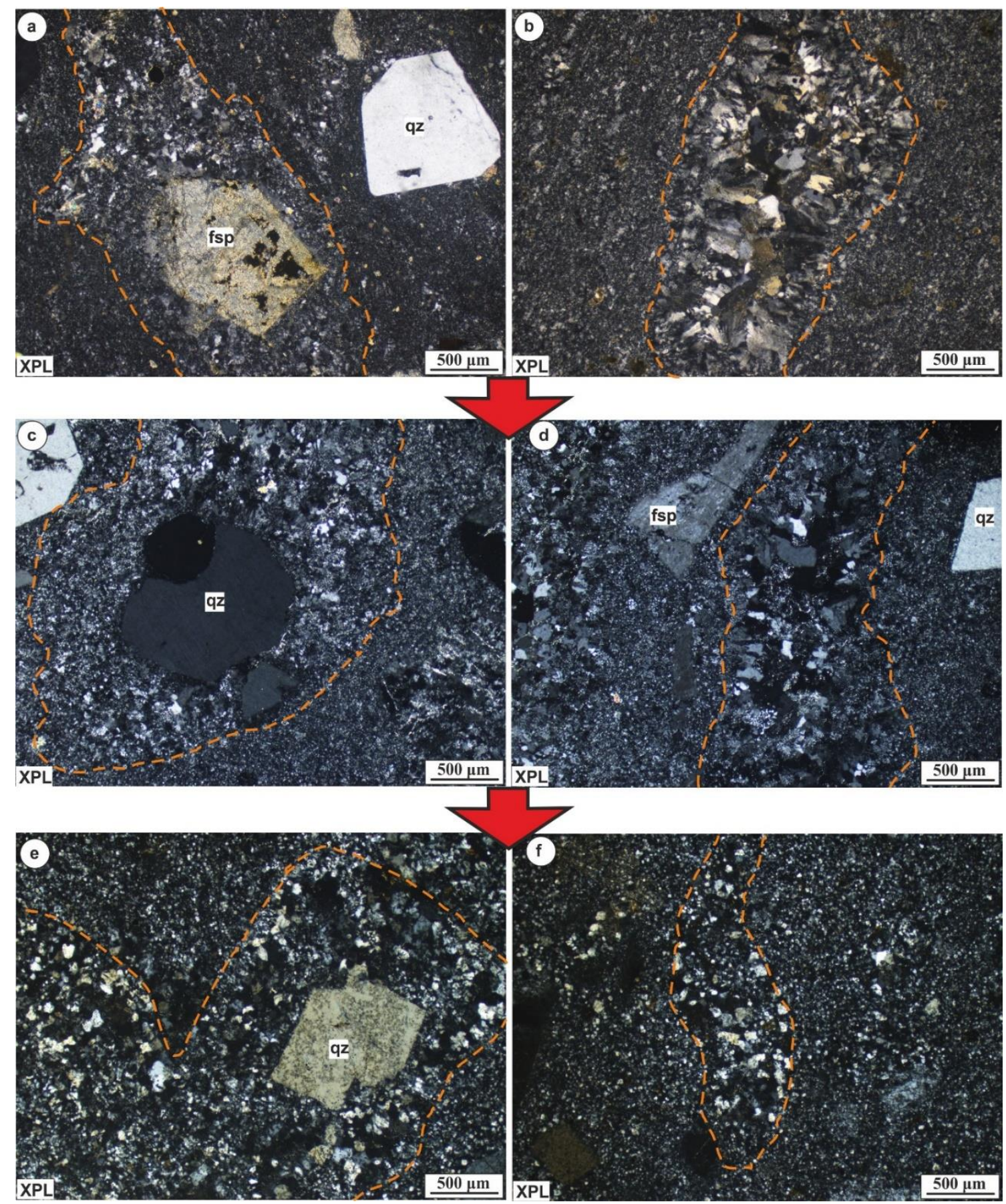

Fig. III.5 Photomicrographs showing the states of the ignimbrite grade continuum from eutaxitic welded ignimbrites to high-grade rheomorphic ignimbrites (emLT and rheoLT). a-b Eutaxitic ignimbrites (emLT, samples ÁGK-1830 and 1821, respectively), containing fiammes with well-visible, definite edge and finegrained groundmass crystals (devitrified glass shards and crystalloclasts); c-d Moderately rheomorphic ignimbrites (rheoLT, sample ÁGK-1790), containing fiammes with visible edge and coarser groundmass crystals; e-f Strongly rheomorphic, extremely high-grade ignimbrites, containing fiammes with barely visible edge and coarser groundmass crystals (rheoLT, sample ÁGK-1243). fsp feldspar, qz quartz. XPL crossed polars. Altered, devitrified fiammes are highlighted by orange dashed lines 


\subsubsection{Matrix-supported, fine-grained, felsitic ash tuff with coated-particles}

\section{(accfrichT)}

The presence of the accfrichT lithofacies was demonstrated only in one borehole in the study area, namely the Battonya-7 borehole (see details in Table III.1), BattonyaPusztaföldvár BR, Békés-Codru Unit (Fig. III.1/c).
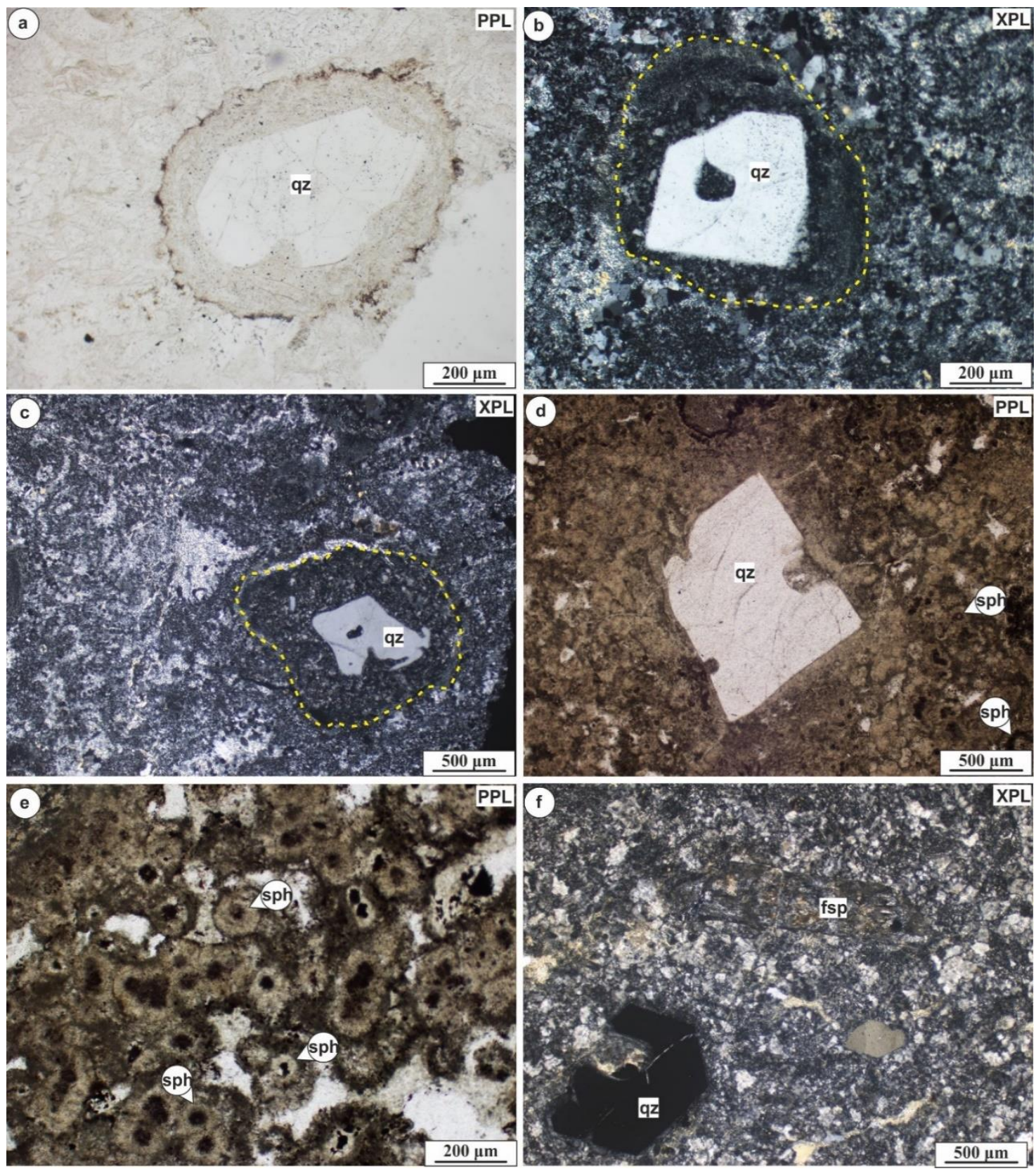

Figure III.6 Photomicrographs of the matrix-supported, fine-grained, felsitic ash tuff with coatedparticles (accfrichT: a-c) and the spherulitic, vitrophyric lava-like ash tuffs (vlava-likeT: e-f), Battonya and Tótkomlós areas, respectively. a-c Sample Bat-7 (Via-79), coated particles (armored pellets) formed around subhedral, resorbed quartz crystals; d Sample T-I $14 \mathrm{MF}$, subhedral, porphyric quartz and spherulites in the matrix; e Sample T-I 14 MF, completely spherulitic groundmass; f Sample T-I 13 MF, subhedral quartz and sericitized feldspar crystals in the matrix affected by pervasive crystallization. $f s p$ feldspar, qz quartz, sph spherulite, $P P L$ plane polarized light, XPL crossed polars 


\section{Description}

The crystal-poor (quartz: 2 vol\%, K-feldspar 8 vol\%) sample shows fine-grained felsitic groundmass (89 vol\%) of quartz, feldspar and sericite with good sorting; however, it differs from all the other samples of the Battonya area in containing mm-sized coated particles (armored pellets, formed around porphyric quartz crystals, 1 vol\%; Fig. III.6/ac). The size of the particles ranges between $0.8 \mathrm{~mm}$ and $1.7 \mathrm{~mm}$ (but never reaches the lapilli size: $2 \mathrm{~mm}$ ), while the quartz crystals in the centre range between 0.5 and $0.8 \mathrm{~mm}$.

\section{Interpretation}

Armored lapilli and pellets are typical in pyroclastic fallout, flow and surge deposits formed by ash accumulation around coarser crystals (in this case porphyric quartz) under wet conditions (Brown et al. 2012). In this way the sample could be associated with the ignimbrite lithofacies (emLT and rheoLT), most possibly formed in a pyroclastic ash cloud (air-fall ash deposit). Good sorting of the sample (contrary to the poorly-sorted ignimbrites; emLT and rheoLT) also strengthens the aforementioned genetics. Armored pellets are absolutely unique not only regarding the samples of the Battonya area but also all Permian ignimbrites of the Tisza MU.

\subsubsection{Lithic-rich, massive, strongly sericitized, poorly-sorted volcaniclastics $(\operatorname{lmLT})$}

The presence of the $\operatorname{lmLT}$ lithofacies was demonstrated in two boreholes in SE Hungary, namely the Biharugra-I and the Tótkomlós-K-3 boreholes (see details in Table III.1), Villány-Bihor Unit and Békés-Codru Unit, respectively (Fig. III.1/b; Fig. III.2).

\section{Description}

The samples are purplish or greenish-gray in color, massive, non-porous pyroclastic or volcanogenic sedimentary rocks that consist of completely sericitized juvenile fragments (from $100 \mu \mathrm{m}$ sized glass shards up to 1-2 mm long fiammes; Fig. III.7/a, f), various fragmented crystals (11-14 vol\%, up to mm size) and subrounded lithics (12-15 vol\%, up to 2-3 cm, but generally around 1-5 mm; Fig. III.7/e and Fig. III.8) with a wide range of origin in a fine matrix (69-76 vol\%) of sericite, quartz and feldspar. The mentioned 
components show very poor sorting in all samples and their proportion is extremely variable.

Very thin bands of sericite up to $\sim 2.5 \mathrm{~mm}$ (showing no preferred orientation) occur in all of the samples (Fig. III.7/a, f). Randomly oriented $\mu$ m-sized patches of sericite can be found in the fine groundmass, as well. The aforementioned components are most
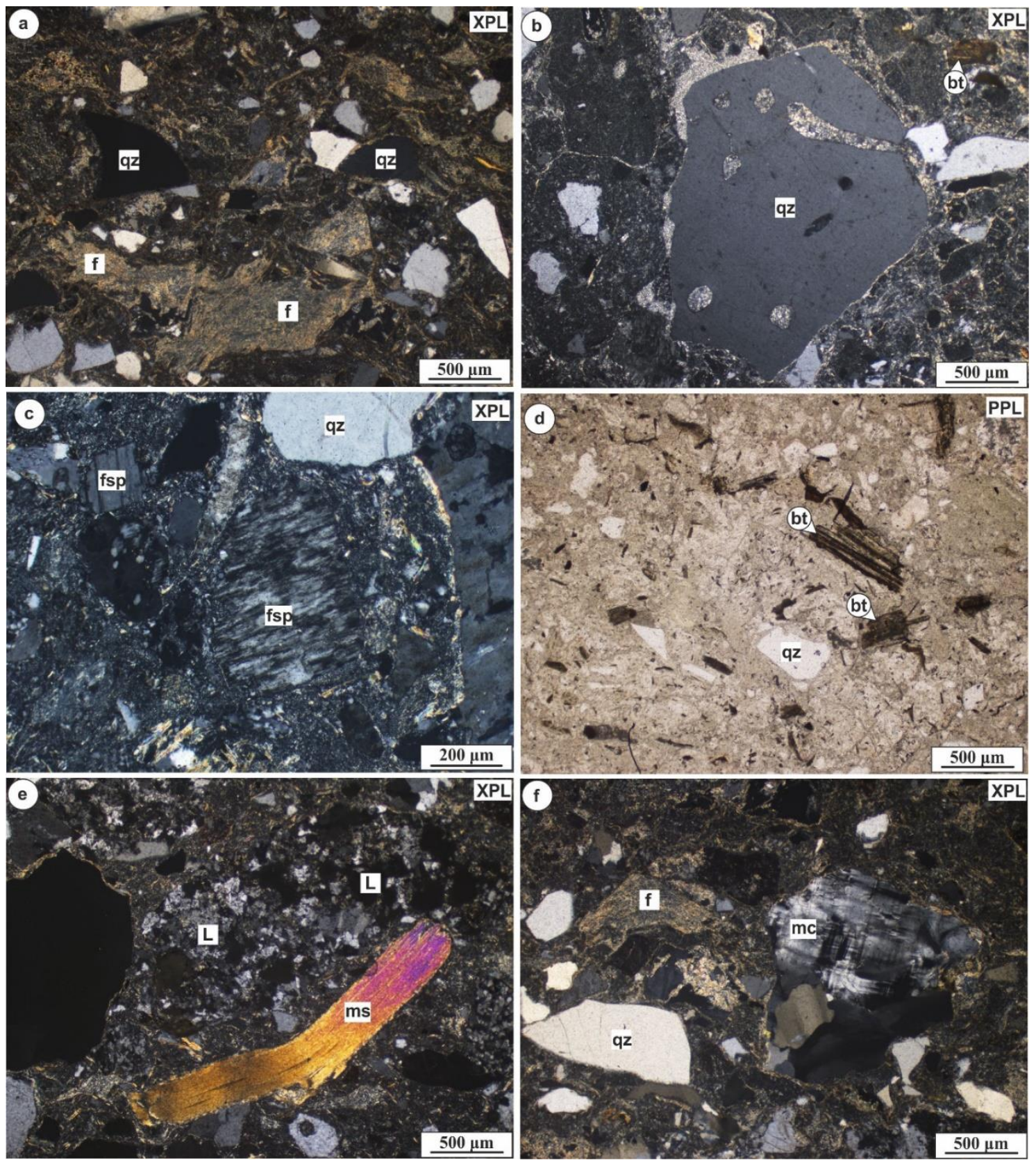

Figure III.7 Photomicrographs of the lithic-rich, massive, strongly sericitized, poorly-sorted volcaniclastics $(\operatorname{lmLT})$, Biharugra and Tótkomlós areas. a Sample BATR/1, poorly-sorted volcaniclastite, containing sericizited fiammes and angular fragments of quartz; b Sample ÁGK-1340-2, subhedral, resorbed magmatic quartz and euhedral biotite crystals; c Sample ÁGK-1339, subhedral polysynthetic plagioclase (left) and K-feldspar (right) crystals; d Sample ÁGK-1340-2, fragmented quartz and euhedral biotite crystals; e Sample ÁGK-1267, muscovite and felsic volcanic lithic clast, having felsitic texture; f Sample BATR/1, microcline, broken quartz crystals, and sericitized juvenile fragments. $b t$ biotite, $f$ altered fiamme, $f s p$ feldspar, $L$ lithic clast, $m c$ microcline, $m s$ muscovite, $q z$ quartz, $P P L$ plane polarized light, $X P L$ crossed polars 
possibly altered, devitrified juvenile fragments (the former: altered, sericitized fiammes, the latter: sericitized glass shards).

Generally two different types of phenocrysts and lithics could be distinguished in the mixed material: (1) primary magmatic crystals and felsic volcanic lithics (8-15 vol\%), suggesting volcanogenic origin and (2) not magmatic or presumably older (plutonic)
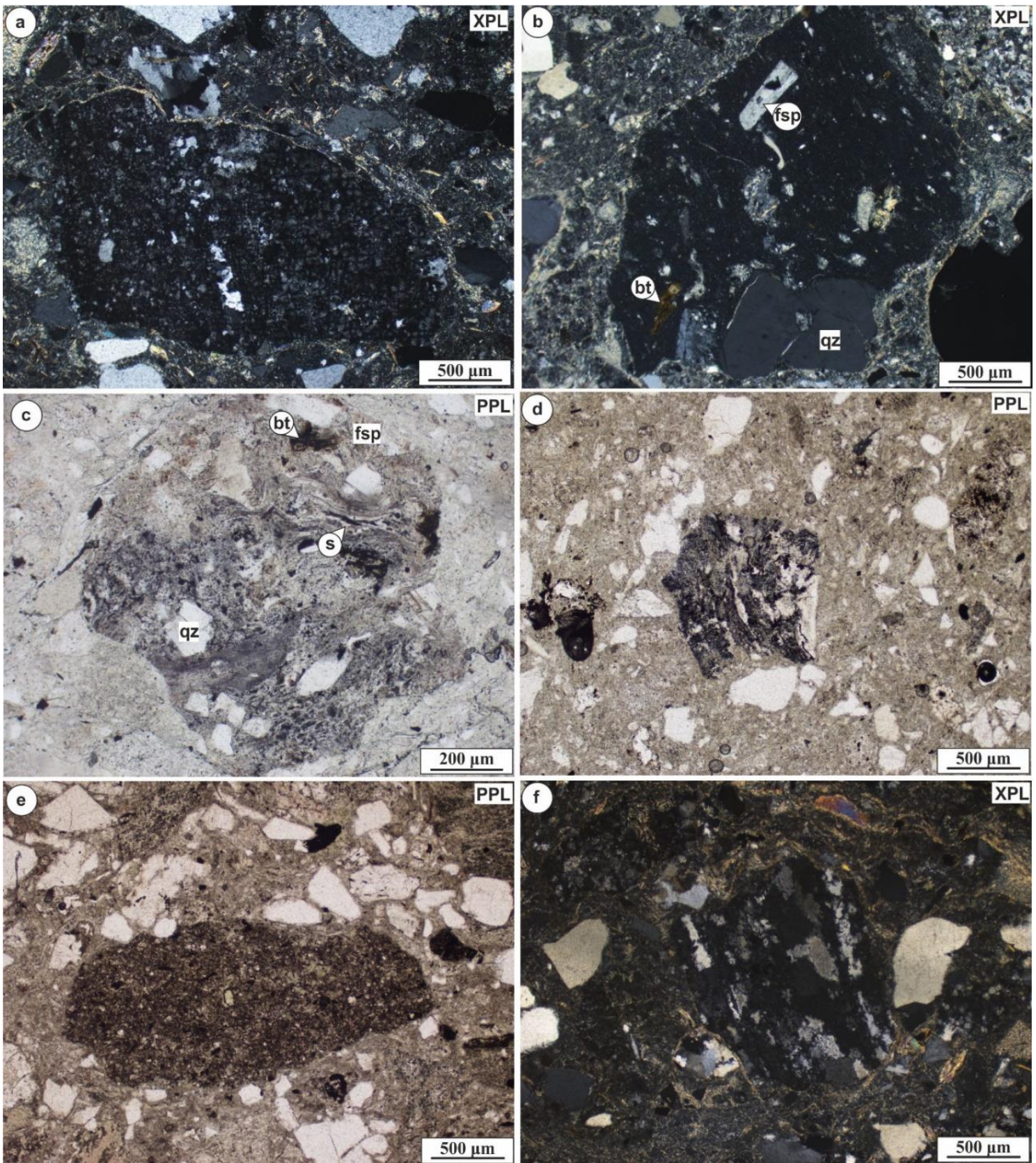

Figure III.8 Volcanic (a-d) and non-volcanic (e-f) lithics from the lithic-rich, massive, strongly sericitized, poorly-sorted volcaniclastics ( $\operatorname{lmLT}$ ). a Sample ÁGK-1267, felsic lithic clast, having felsitic, spherulitic texture; b Sample ÁGK-1340, quartz-feldspar-biotite porphyric lithic clast, having fine groundmass; c Sample ÁGK-1339, felsic lithic clast, containing recognizable oriented juvenile components (glass shards); pyroclastite clast; d Sample ÁGK-1267, dark-colored, fine-grained, hematitized (mafic-intermediate?) lithic clast; e Sample BATR/1, fine-grained sedimentary lithic clast (claystone or siltstone); f Sample ÁGK-1267, polycrystalline metamorphic quartz. $b t$ biotite, $f_{s p}$ feldspar, $q z$ quartz, $s$ altered glass shard, $P P L$ plane polarized light, $X P L$ crossed polars 
crystals (e.g., polycrystalline, metamorphic quartz or microcline, respectively) and nonvolcanic (e.g., sedimentary or metamorphic) lithics (0-4 vol\%).

Magmatic crystals are porphyric, subhedral quartz (59-82 vol\%; Fig. III.7/b) with straight extinction and many broken, angular fragments (100-200 $\mu \mathrm{m}$; Fig. III.7/a, d, f); subhedral, strongly sericitized, often Carlsbad twinned K-feldspar (13-28 vol\%) and polysynthetic plagioclase (6-13 vol\%, Fig. III.7/c) with broken feldspar fragments (100$200 \mu \mathrm{m})$ and euhedral, idiochromatic biotite $(<1$ vol\%, up to $600 \mu \mathrm{m}$; Fig. III.7/b, d) rarely replaced by opaque minerals. As an accessory component, subhedral broken, fractured zircon (up to $150 \mu \mathrm{m}$ ) also occur in the groundmass. Volcanic lithics (8-15 vol\%) form four main groups: (1) felsic lithics with felsitic or spherulitic texture ( $60 \%$; Fig. III.7/e and Fig. III.8/a), (2) quartz-feldspar-biotite porphyric lithics with fine matrix ( 15\%; Fig. III.8/b), (3) felsic lithics with recognizable oriented juvenile components (glass shards, smaller fiammes) (pyroclastite; 10\%; Fig. III.8/c), (4) and dark-colored, fine-grained, hematitized (mafic-intermediate?) lithics ( 15\%; Fig. III.8/d).

Coarser polycrystalline quartz grains with undulose extinction are also present as well as mm-sized crystals of muscovite (Fig. III.7/e), microcline (Fig. III.7/f) and biotite.

Non-volcanic lithics $(0-4$ vol\%) are the following: fine-grained reddish or brownish sedimentary (claystone or siltstone; 30\%; Fig. III.8/e), metamorphic lithics built up by undulose quartz and muscovite (mica schist or gneiss; 15\%) and polycrystalline metamorphic quartz ( 55\%; Fig. III.8/f).

\section{Interpretation}

Strongly sericitized juvenile fragments (altered glass shards and fiammes) have uniequivocally pyroclastic origin. The lack of preferred orientation of the pyroclastic material suggests non-welded texture. Crystals could be primary magmatic such as resorbed, magmatic quartz, K-feldspar, plagioclase and biotite or derive from older igneous and metamorphic rocks (polycrystalline quartz with undulose extinction, microcline, muscovite). Lithics also represent a wide range of origin; volcanic clasts (Fig. III.7/e and Fig. III.8/a-d) are more abundant than lithics from the underlying sedimentary (claystone, siltstone) or metamorphic (mica schist or gneiss) rocks (Fig. III.8/e, f). The chaotic texture with various subrounded lithics, juvenile and crystal fragments suggests that sedimentation and volcanic activity could occur simultaneously. The rocks could be interpreted as resedimented volcanic rocks (Tótkomlós-K-3) or the more mixed material 
of the Biharugra-I borehole as a volcanogenic sedimentary rock (tuffaceous sandstone according to the grain size; McPhie et al. 1993).

\subsubsection{Spherulitic, vitrophyric lava-like ash tuffs (vlava-likeT)}

The presence of the vlava-likeT lithofacies was demonstrated in the Tótkomlós-I borehole (Fig. III.1/b; Fig. III.2), Békés-Codru Unit. Drill cores from 3 separate depths were observed (drill cores 13-15, see details in Table III.1). In this area, corresponding to a separated tectonic block of the basement, the Permian sequence is covered by Mesozoic sedimentary basement formations (Fig. III.2). The cores exposed felsic volcanic rocks in a minimum thickness of $156 \mathrm{~m}$; however, they are petrographically rather homogeneous, only the lowest part of the sequence (drill core 15) differs which is strongly deformed in brittle style (brecciated).

\section{Description}

Samples of the Tótkomlós-I borehole show vitrophyric texture with 10 vol\% quartz and altered feldspar phenocrysts in a devitrified, completely spherulitic groundmass (90 vol\%; Fig. III.6/d, e). The diameter of the spherulites ranges between 50 and $100 \mu \mathrm{m}$. On the other hand, no additional textural features (i.e., remnants of juvenile fragments) could be observed. The major mineral assemblage is rather similar to the ignimbrites of the Battonya area with porphyric (up to 1-2 mm) euhedral or subhedral quartz (55 vol\%; Fig. III.6/d, f) and sericitized or carbonatized feldspar crystals (45 vol\%; Fig. III.6/f), showing low-crystal breakage.

\section{Interpretation}

According to the mineralogical composition, the samples of the Tótkomlós-I borehole are rhyolites; however, their genetic interpretation is very complicated. Spherulitic texture suggests hight-temperature crystallization which could be the feature of the inner part of both lavas and welded ignimbrite sheets (Breitkreuz 2013). Although the thickness ( 150 m, measured from borehole data, Table III.1) and some textural features (e.g., spherulites in microcrystalline matrix) are consistent with the central part of silicic lavas (Orth and McPhie 2003), the altered vitroclastic groundmass, broken phenocrystals and compositional similarity to all the other studied lithologies (i.e., pyroclastic rocks) might indicate a pyroclastic origin. The spherulite and groundmass crystallization could occur 
in the interior of the unit under moderate cooling conditions $\left(\Delta \mathrm{T}\right.$ : $50-200{ }^{\circ} \mathrm{C}$; Swanson et al. 1989). Lower breccia zones could generally point to brittle fragmentation near the flow base; however, in this case, taking into consideration the tectonic evolution of the Tótkomlós area (see details of the local faulting in Fig. III.2), it is more probable that tectonic deformation and brecciation occurred. In some samples, the entire rock, even the spherulitic matrix, is crosscut by fractures.

\subsection{Discussion}

\subsubsection{Petrographic (re)interpretations according to the new observations and archive reports}

New petrographic observations resulted in a quite different approach to Permian volcanism in SE Hungary. The detailed description and classification of textural features allow us to distinguish between different transport and emplacement mechanisms associated with effusive and explosive eruption styles. Based on the variations in lithology, the studied samples were identified mainly as pyroclastic rocks (predominantly ignimbrites) and volcanic sediments. The textural investigations established the discrimination of two major lithofacies groups: (1) the Battonya area is represented by crystal-poor (8-20 vol\%) welded (with eutaxitic texture: emLT) and rheomorphic ignimbrites with rhyolitic composition that often resemble lavas (rheoLT), while, the other group (2) consists of strongly sericitized, lithic-rich reworked pyroclastic (probably non-welded ignimbrites) and volcanogenic sedimentary rocks that occur in the Tótkomlós and the Biharugra areas, respectively $(\operatorname{lm} L T)$.

Interpretation of rheomorphic ignimbrites was difficult as they do not have vitroclastic groundmass and show low crystal breakage. However, oriented and devitrified fiammes in these rocks without sharp, definite edge serve as a potential evidence of their rheomorphic origin. Such parts of the samples were previously interpreted as the alternation of volatile-rich and volatile-poor bands within the presumed lava flow by Szepesházy (1967). It is important to note, that in the $c a .60 \mathrm{~km}^{2}$ area (Fig. III.1/c), all felsic volcanic rocks are derived from similar well depths of the boreholes (Table III.1; Fig. III.2). Their average minimum thickness is around $20 \mathrm{~m}$ (with no information about the whole thickness of any volcanic sequences near Battonya), and the calculated minimum volume of the volcanic products is $1.2 \mathrm{~km}^{3}$. The lack of characteristic lava associated facies variations (e.g., no brecciated lava carapace facies) in an area that 
could be commensurable with a rhyolitic lava flow (or dome) rather points to an ignimbrite sheet that consists of altered crystal-poor, fiamme-bearing lapilli tuffs with rhyolitic composition formed under distinct steps of the ignimbrite grade continuum (Branney et al. 1992; Henry and Wolff 1992). Most possibly, however, only a piece of an ignimbrite sheet was drilled in the Battonya area, as both conventional and rheomorphic ignimbrite sheets are generally much more extensive (their length up to $\sim 60 \mathrm{~km}$ and maximum thickness is $\sim 100 \mathrm{~m}$; Henry and Wolff 1992). The Battonya-7 borehole encountered a pyroclastic rock with armored pellets (around quarzt crystals; accfrichT), suggesting its formation in a pyroclastic ash cloud under wet conditions. Beside the fact that such coated particles are so far unique regarding the Permian volcanism of the Tisza MU, they reinforce the explosive origin of the surrounding rocks (i.e., rheoLT facies $<1$ $\mathrm{km}$ away). Moreover, Permian volcanic rocks of the Tisza MU are dominantly felsic ignimbrites, while lavas are rather subordinate (Nicolae et al. 2014, Szemerédi et al. 2016, 2017, 2018a, 2020a).

Reworking of such pyroclastic rocks could result in the volcanogenic sedimentary sequences of the Biharugra and the Tótkomlós areas that are rich in volcanic lithics and sericitized juvenile fragments. These rocks could have been formed in a basin where volcanic and non-volcanic sedimentation occurred at the same time. Such volcanogenic sedimentary rocks are also known from the Western Mecsek Mts within the Cserdi Conglomerate Formation that covers the Permian felsic volcanic rocks in that region (Varga 2009). The various volcanic lithics in the $\operatorname{lmLT}$ might suggest multiple-phase Permian volcanic activity that was also documented from the Apuseni Mts (Codru NS; Nicolae et al. 2014). In the Tótkomlós-I borehole, the felsic volcanic rocks (drill cores from three distinct depths) have vitrophyric texture, completely spherulitic groundmass and minor broken crystals. Based on these features (with the lack of altered fiammes) it is not possible to interpret the samples uniequivocally (ignimbrites or lavas); however, it is the most probable that they represent the ultimate step of the ignimbrite grade continuum as lava-like ash tuffs (vlava-likeT; Branney et al. 1992; Henry and Wolff 1992). However, being part of a tectonic block separate from the Battonya area (Fig. III.2), it is also possible that these samples represent a completely distinct (i.e., younger or older) volcanic episode.

According to the previous petroleum exploration reports (Szepesházy 1967; Körössy 2005a) a direct plutonic-volcanic relationship was supposed between the "Battonya quartz-porphyry" (thought to be Lower Permian) and the underlying Variscan 
"Battonya granite". This view was based on the interpretation that the former represents either subvolcanic or surficial lavas that continue as granite towards crustal depths. Our new volcanological interpretation precludes such a direct connection between the ignimbrite and the underlying granite and suggests tectonic or erosional unconformity between them.

\subsubsection{Syn and post emplacement textural development}

As ancient volcanic rocks might be affected by various processes of alteration, their primary (syn) and secondary (post emplacement) textural features could be rather difficult to distinguish (e.g., Allen 1988; Branney and Kokelaar 1992; Branney et al. 1992; Henry and Wolff 1992; Gifkins et al. 2005a,b). Based on the petrographic observations of the studied rocks, various lithofacies were distinguished (Table III.2); however, some general textural features do deserve additional discussion. All of these features are summarized in Table III.4, and the relative timescale of the related processes is displayed in Figure III.9, which is based on several experimental and volcanological case studies (Lofgren 1971; Swanson et al. 1989; Stevenson et al. 1994; Orth and McPhie 2003; Breitkreuz 2015). Primary (magmatic) phenocrysts are similar in all lithofacies, suggesting compositionally similar rhyolitic sources (crystallization above $850-800{ }^{\circ} \mathrm{C}$ and low $\Delta \mathrm{T}$; Swanson et al. 1989). Microcrystalline groundmass of quartz, feldspar and sericite is also a common feature of the studied samples. Felsitic textures suggests pervasive groundmass crystallization simoultanoeusly and after microlith formation (at high $\Delta \mathrm{T}$; Swanson et al. 1989), while spherulite formation as another type of post emplacement high-temperature $\left(800-500^{\circ} \mathrm{C}\right)$ groundmass crystallization occurred at restricted point sources at moderate $\left(50-150{ }^{\circ} \mathrm{C}\right) \Delta \mathrm{T}$ (vlava-likeT; Swanson et al. 1989; Breitkreuz 2013).

Eutaxitic textures with flattened, deformed, devitrified fiammes and glass shards were formed by welding processes (e.g., Gifkins et al. 2005a,b). Irregular, randomly oriented devitrified juvenile fragments occurring in the samples of the Biharugra and the Tótkomlós areas suggest the lack of welding processes (non-welded pyroclastic or volcanogenic sedimentary rocks; McPhie et al. 1993; Gifkins et al. 2005a,b). However, the devitrification of juvenile fragments occurred at lower temperatures $\left(<500{ }^{\circ} \mathrm{C}\right)$ than the microlith formation $\left(850-650{ }^{\circ} \mathrm{C}\right)$ or the crystallization of spherulites (Fig. III.9; Lofgren 1971; Swanson et al. 1989; Stevenson et al. 1994; Orth and McPhie 2003; Breitkreuz 2015). The quenching experiments on Miocene calc-alkaline silicic glasses 
predicted the solidification temperature around $690-710^{\circ} \mathrm{C}$ (Szepesi et al. 2019), while the minimum welding temperature can reduced by the variations in $\mathrm{H}_{2} \mathrm{O}$ content $(\sim 600$ ${ }^{\circ} \mathrm{C}$; Quane and Russel 2005).

Table III.4 Summary of the most significant textural features observed by each lithofacies of the Permian felsic volcanic rocks in SE Hungary. Abbreviations are listed in Tables III.2 and III.3. fsp feldspar, $q z$ quartz, ser sericite, + rare, ++ moderate, +++ frequent, - not present

\begin{tabular}{|c|c|c|c|c|c|}
\hline Feature & emLT & rheoLT & accfrichT & $\operatorname{lmLT}$ & vlava-likeT \\
\hline $\begin{array}{l}\text { Microcrystalline } \\
\text { matrix }\end{array}$ & $\mathrm{qz}, \mathrm{fsp}$ & $\mathrm{qz}, \mathrm{fsp}$, ser & qz, fsp, ser & ser, qz, fsp & $q z, f s p$ \\
\hline Spherulite & + & + & - & - & +++ \\
\hline Eutaxitic & +++ & + & - & - & - \\
\hline Glass shards & $\begin{array}{l}\text { flattened } \\
\text { (qz, fsp) }\end{array}$ & - & - & thin bands (ser) & - \\
\hline Fiammes & $\begin{array}{l}\text { flattened } \\
(\mathrm{qz}, \mathrm{fsp})\end{array}$ & $\begin{array}{l}\text { flattened } \\
(\mathrm{qz}, \mathrm{fsp})\end{array}$ & - & irregular (ser) & - \\
\hline $\begin{array}{l}\text { Broken } \\
\text { phenocrystals }\end{array}$ & ++ & + & - & +++ & + \\
\hline Lithics & - & - & - & ++ & - \\
\hline $\begin{array}{l}\text { Non-volcanic } \\
\text { lithics }\end{array}$ & - & - & - & ++ & - \\
\hline Coated particles & - & - & ++ & - & - \\
\hline $\begin{array}{l}\text { phenocryst gro } \\
\text { emLT rheoL7 } \\
\text { accfrich } T I m L 7 \\
\text { vlava-like } T\end{array}$ & $\begin{array}{l}800^{\circ} \mathrm{C} \\
\mathrm{ImLT} \\
\mathrm{mLT}\end{array}$ & $\begin{array}{l}\text { tallization of } \\
T \quad \text { rheo } \\
\text { vlava-like } 7 \\
\text { on (groundr } \\
\text { llava-like T }\end{array}$ & herulites & \multicolumn{2}{|c|}{$200^{\circ} \mathrm{C}$} \\
\hline
\end{tabular}

Figure III.9 The relative timescale of the most significant processes in the textural development of the Permian felsic volcanic rocks. Each process is marked by its representative lithofacies (modified after Lofgren 1971; Swanson et al. 1989; Stevenson et al. 1994; Orth and McPhie 2003; Breitkreuz 2015)

Volcanic and non-volcanic lithics were ripped by explosive eruptions and represent older components than the host material. Coated particles formed by ash accumulation around coarser crystals under wet conditions in the ash cloud of eruption or pyroclastic density flow (Brown et al. 2012).

\subsubsection{Local and regional correlation}

Based on the Mesozoic evolution (Alpine nappe stacking) of the Tisza MU, the BékésCodru Unit was correlated with the Codru NS, Apuseni Mts (Szederkényi et al. 2013 and references therein; Fig. III.10). Thus, the area of this study (based on the lithological 
sequence of the Tótkomlós-I borehole) was correlated with the Finiş Nappe, Codru NS (Szepesházy 1979; Körössy 2005a; Fig. III.10). Regarding the petrography, however, significant differences were found between the samples of the Codru NS (Finiş, Dieva and Moma Nappes, based on Nicolae et al. 2014) and the felsic volcanic rocks of SE Hungary (Békés-Codru Unit). Pyroclastic rocks in the Apuseni Mts are crystal-rich ( 40 vol\%) and contain abundant biotite, altered pyroxene and accessory garnet crystals (Nicolae et al. 2014; Szemerédi et al. 2018a). On the other hand, the samples of this study show much lower crystal content (8-20 vol\%), biotite is very rare and no pyroxene or garnet crystals were identified. Neither is any evidence of bimodal Permian volcanic rocks known from the boreholes of SE Hungary, while in the Codru NS cogenetic basalts and subordinate andesites also occur (Nicolae et al. 2014).

\begin{tabular}{|c|c|c|c|c|c|}
\hline \multicolumn{6}{|c|}{ Tisza Mega-unit } \\
\hline \multicolumn{3}{|c|}{$\begin{array}{c}\text { Southern Transdanubia, eastern Pannonian Basin } \\
\text { (Hungary) }\end{array}$} & \multicolumn{3}{|c|}{ Apuseni Mts (Romania) } \\
\hline & & & \multirow{2}{*}{$\begin{array}{l}\text { Biharia } \\
\text { Nappe } \\
\text { System }\end{array}$} & $\begin{array}{l}\text { Arieşeni } \\
\text { Unit }\end{array}$ & \multirow{2}{*}{$\begin{array}{c}\text { crystal-rich } \\
\text { ignimbrites } \\
\text { (rhyodacitic-dacitic, } \\
\text { low-grade } \\
\text { metamorphic) }\end{array}$} \\
\hline & & & & $\begin{array}{l}\text { Gârda } \\
\text { Unit }\end{array}$ & \\
\hline \multirow{3}{*}{$\begin{array}{l}\text { Békés- } \\
\text { Codru Unit }\end{array}$} & \multirow{2}{*}{\begin{tabular}{|c|} 
Battonya- \\
Pusztaföldvár \\
Basement \\
Ridge
\end{tabular}} & \multirow[b]{2}{*}{$\begin{array}{l}\text { crystal-poor ignimbrites } \\
\text { (rhyolitic) } \\
\text { correlation b }\end{array}$} & \multirow{3}{*}{$\begin{array}{l}\text { Codru } \\
\text { Nappe } \\
\text { System }\end{array}$} & $\begin{array}{l}\text { Moma } \\
\text { Unit }\end{array}$ & \multirow{2}{*}{$\begin{array}{l}\text { bimodal volcanism } \\
\text { (crystal-rich } \\
\text { rhyodacitic-dacitic) } \\
\text { ignimbrites and } \\
\text { mafic-intermediate } \\
\text { lavas) }\end{array}$} \\
\hline & & & & $\begin{array}{l}\text { Dieva } \\
\text { Unit }\end{array}$ & \\
\hline & Kelebia area & $\begin{array}{c}\text { crystal-rich ignimbrites } \\
\text { (rhyodacitic-dacitic, } \\
\text { low-grade } \\
\text { metamorphic) }\end{array}$ & & $\begin{array}{l}\text { Finiş } \\
\text { Unit }\end{array}$ & $\begin{array}{l}\text { garnet bearing } \\
\text { crystal-rich } \\
\text { ignimbrites } \\
\text { (rhyodacitic-dacitic) }\end{array}$ \\
\hline \multirow{2}{*}{$\begin{array}{l}\text { Villány- } \\
\text { Bihor Unit }\end{array}$} & $\begin{array}{l}\text { Máriakéménd- } \\
\text { Báta Basement } \\
\text { Range } \\
\end{array}$ & $\begin{array}{l}\text { crystal-rich ignimbrites } \\
\text { (rhyodacitic-dacitic) }\end{array}$ & \multirow{2}{*}{$\begin{array}{c}\text { Bihor } \\
\text { Autochtone } \\
\text { Unit }\end{array}$} & \multirow{2}{*}{$\begin{array}{l}\text { Bihor } \\
\text { Unit }\end{array}$} & \multirow{2}{*}{$\begin{array}{l}\text { Permian volcanic or } \\
\text { volcano-sedimentary } \\
\text { deposits are sporadic }\end{array}$} \\
\hline & $\begin{array}{l}\text { Northern } \\
\text { foreland of the } \\
\text { Villány Mts }\end{array}$ & $\begin{array}{c}\text { garnet bearing crystal- } \\
\text { rich ignimbrites and } \\
\text { lavas (rhyodacitic- } \\
\text { dacitic) }\end{array}$ & & & \\
\hline $\begin{array}{c}\text { Mecsek } \\
\text { Unit }\end{array}$ & $\begin{array}{c}\text { Western } \\
\text { Mecsek Mts }\end{array}$ & $\begin{array}{l}\text { crystal-rich ignimbrites } \\
\text { (rhyodacitic-dacitic) }\end{array}$ & & & \\
\hline
\end{tabular}

Figure III.10 Correlation between the Alpine facies zones of the Tisza Mega-unit (Hungary) and the tectonic units of the Apuseni Mts, highlighting the results of Szepesházy (1979). Data are based on Szederkényi (2013), Nicolae et al. (2014); and Szemerédi et al. (2020a)

Such petrographic differences were also found between the Permian felsic volcanic rocks of S Transdanubia and the samples of this study. In the Western Mecsek Mts and Máriakéménd-Báta BR, crystal-rich (40-45 vol\%) ignimbrites occur that contain hematitized biotite and strongly altered pyroxene as mafic components (Szemerédi et at. 2016, 2020a). At the northern foreland of the Villány Mts similar (biotite and pyroxene- 
bearing) ignimbrites with accessory garnet are present and they are accompanied by subordinate felsic lavas (Szemerédi et al. 2017).

The mentioned petrographic differences are consistent with the slighter geochemical and geochronological distinctions revealed by our previous studies (Szemerédi et al. 2020a). According to the immobile element-based rock classification $\left(\mathrm{Zr} / \mathrm{TiO}_{2}\right.$ vs. Nb/Y; Winchester and Floyd 1977), felsic volcanic rocks in SE Hungary are predominantly rhyolites (samples of this study), while felsic volcanic rocks from $S$ Transdanubia and the Apuseni Mts (Nicolae et al. 2014) are rhyodacites-dacites. The immobile element (high field strength elements, rare earth elements) patterns are rather uniform for all Permian volcanic rocks of the Tisza MU; however, the highest values are shown by the samples of SE Hungary in both light and heavy rare earth elements (Szemerédi et al. 2020a, see detail in Chapter IV). Regarding the geochronological results (zircon $\mathrm{U}-\mathrm{Pb}$ ages), the samples of this study are slightly younger $(259.5 \pm 2.6 \mathrm{Ma}$ from BATR/1 and BATR/2 samples, Tótkomlós-K-3 borehole) than all the other Permian felsic volcanic rocks of the Tisza MU, which range between $263.4 \pm 2.7$ and $266.8 \pm 2.7 \mathrm{Ma}$ (Szemerédi et al. 2020a, see details in Chapter IV).

\subsubsection{Emplacement of the Permian felsic volcanic rocks in SE Hungary within the Permian volcanic system of the Tisza Mega-unit}

The new results suggest that the Permian felsic volcanic rocks in SE Hungary (Battonya, Biharugra and Tótkomlós areas) might represent the youngest and most evolved, crystalpoor rhyolitic magmas of a large-volume silicic (crystal-rich rhyodacitic-dacitic) volcanism with slighter geochemical, geochronological and remarkable petrographic differences compared to other Permian felsic volcanic rocks in the Tisza MU. Based on the Alpine evolution of the Tisza MU, the Békés-Codru Unit was correlated with the Codru NS (Apuseni Mts; Fig. III.10); however, Permian felsic volcanic rocks in SE Hungary do not show any correlation with similar rock types (felsic ignimbrites) in any nappes of the Codru NS (based on Nicolae et al. 2014): neither the garnet-bearing crystalrich samples of the Finiş Nappe (as it was supposed by Szepesházy 1979), nor the ignimbrites of the Dieva and Moma Nappes that are part of a bimodal volcanic suite (Nicolae et al. 2014). Such crystal-poor ignimbrites are unknown as yet from the Tisza Mega-unit and might represent a petrographically and geochemically distinct, younger ( 
259 Ma; Szemerédi et al. 2020a) episode of the Permian volcanism in the Pannonian Basin.

\subsection{Conclusions}

(1) Permian felsic volcanic rocks in SE Hungary were previously described and interpreted in the archive reports of petroleum exploration predominantly as lavas ("Battonya quartz-porphyry"). We showed that they are predominantly welded or rheomorphic (Battonya area), rarely lava-like ignimbrites (Tótkomlós-I borehole) and reworked pyroclastic/volcanogenic sedimentary rocks (Tótkomlós and Biharugra areas).

(2) Volcaniclastites from the Biharugra and the Tótkomlós areas consist of various felsic volcanic and non-volcanic lithics and might suggest a multiple-phase Permian volcanic activity that was also documented from the nearby Apuseni Mts, Romania (Codru Nappe System; Nicolae et al. 2014)

(3) Felsic volcanic rocks in SE Hungary belong to the Permian volcanic system of the Tisza Mega-unit; however, some significant petrographic differences (crystal-poorness, rare biotite, no pyroxene or garnet crystals) were observed compared to other Permian felsic volcanic rocks in the Tisza Mega-unit (Nicolae et al. 2014; Szemerédi et al. 2020a). Thus, Permian volcanic rocks in SE Hungary might represent the most evolved, crystalpoor rhyolitic magmas of a large-volume silicic (crystal-rich, rhyodacitic-dacitic) volcanic system.

(4) In contrast to the previous hypothesis (Szepesházy 1979; Császár 2005), Permian felsic volcanic rocks of the Battonya area do not show any correlations with either the similar samples of the Finiş Nappe, Codru Nappe System, or the Permian felsic volcanic rocks in any nappes of the Codru Nappe System, as well as there is no relevant plutonicvolcanic connection between the (presumably older) "Battonya granite" and the "Battonya quartz-porphyry". 


\title{
CHAPTER IV
}

\section{PERMIAN FELSIC VOLCANIC ROCKS IN THE PANNONIAN BASIN (HUNGARY): NEW PETROGRAPHIC, GEOCHEMICAL, AND GEOCHRONOLOGICAL RESULTS}

\author{
Máté Szemerédi \\ Department of Mineralogy, Geochemistry and Petrology, 'Vulcano' Petrology and Geochemistry Research \\ Group, University of Szeged, Szeged, Hungary; MTA-ELTE Volcanology Research Group, Budapest, \\ Hungary \\ email: h462582@stud.u-szeged.hu; szemeredi.mate@gmail.com
}

\section{Réka Lukács}

MTA-ELTE Volcanology Research Group, Budapest, Hungary; Department of Mineralogy, Geochemistry and Petrology, 'Vulcano' Petrology and Geochemistry Research Group, University of Szeged, Szeged, Hungary email: reka.harangi@gmail.com

\section{Andrea Varga}

Department of Mineralogy, Geochemistry and Petrology, 'Vulcano' Petrology and Geochemistry Research Group, University of Szeged, Szeged, Hungary email: raucsikvarga@geo.u-szeged.hu

\section{István Dunkl}

Geoscience Center, Department of Sedimentology \& Environmental Geology, University of Göttingen, Göttingen, Germany email: istvan.dunkl@geo.uni-goettingen.de

\section{Sándor Józsa}

Department of Petrology and Geochemistry, Eötvös Loránd University, Budapest, Hungary email: sandor.jozsa@geology.elte.hu

\section{Mihai Tatu}

Institute of Geodynamics, Romanian Academy, Bucharest, Romania email: mtatu@geodin.ro

\section{Elemér Pál-Molnár}

Department of Mineralogy, Geochemistry and Petrology, 'Vulcano' Petrology and Geochemistry Research Group, University of Szeged, Szeged, Hungary; MTA-ELTE Volcanology Research Group, Budapest, Hungary email: palm@geo.u-szeged.hu

\section{János Szepesi}

MTA-ELTE Volcanology Research Group, Budapest, Hungary; Isotope Climatology and Environmental Research Centre (ICER), Institute of Nuclear Research, Hungarian Academy of Sciences, Debrecen, Hungary email: szepeja@gmail.com

\section{Marcel Guillong}

Institute of Geochemistry and Petrology, Department of Earth Sciences, ETH Zürich, Zürich, Switzerland email: marcel.guillong@erdw.ethz.ch

\section{György Szakmány}

Department of Petrology and Geochemistry, Eötvös Loránd University, Budapest, Hungary email: gyorgy.szakmany@geology.elte.hu

\section{Szabolcs Harangi}

Department of Petrology and Geochemistry, Eötvös Loránd University, Budapest, Hungary; MTA-ELTE

Volcanology Research Group, Budapest, Hungary email: szabolcsharangi@gmail.com

International Journal of Earth Sciences

109, 101-125 (2020)

DOI 10.1007/s00531-019-01791-X 


\title{
Permian felsic volcanic rocks in the Pannonian Basin (Hungary): new
} petrographic, geochemical, and geochronological results

by: Máté Szemerédi, Réka Lukács, Andrea Varga, István Dunkl, Sándor Józsa, Mihai

Tatu, Elemér Pál-Molnár, János Szepesi, Marcel Guillong, György Szakmány and Szabolcs Harangi

\begin{abstract}
Two distinct Permian volcanic epochs were revealed in the Pannonian Basin (eastern Central Europe) by U-Pb zircon geochronology: an older one ( 281 Ma, Cisuralian) in the ALCAPA Mega-unit (Central Transdanubia, Hungary) and a younger volcanic episode ( 267-260 Ma, Guadalupian) in the Tisza Mega-unit (Southern Transdanubia and the eastern Pannonian Basin, Hungary). The former is represented by dacitic subvolcanic rocks (dykes) and lavas, while the latter is dominantly by crystal-rich rhyolitic-rhyodacitic/dacitic ignimbrites and subordinate rhyodacitic/dacitic lavas. Whole-rock (major and trace element) geochemical data and zircon $U-P b$ ages suggest close relationship between the samples of Central Transdanubia and volcanic rocks of the Northern Veporic Unit (Western Carpathians, Slovakia), both being part of the ALCAPA Mega-unit. Such correlation was also revealed between the Permian felsic volcanic rocks of the Apuseni Mts (Romania) and the observed samples of Southern Transdanubia and the eastern Pannonian Basin that are parts of the Tisza Mega-unit. The older volcanic rocks ( 281-265 Ma) could be linked to post-orogenic tectonic movements, however, the youngest samples ( 260 Ma, eastern Pannonian Basin, Tisza Mega-unit) could be formed in the extensional setting succeeding the post-collisional environment. On the whole, the observed Permian magmatic rocks show significant similarity with those of the Western Carpathians.
\end{abstract}

\subsection{Introduction}

During the Permo-Carboniferous times several intramontane basins were formed along the European Variscan Orogenic Belt genetically controlled by a post-collisional to extensional tectonic regime associated with intense magmatic activity often having bimodal (basaltic-dacitic/rhyolitic) character (Cortesogno et al. 1998; Awdankiewicz 1999; Wilson et al. 2004; Paulick and Breitkreuz 2005; Vozárová et al. 2009, 2015, 2016; Seghedi 2010; Wilcock et al. 2013; Letsch et al. 2014; Nicolae et al. 2014; Repstock et al. 2017; Ondrejka et al. 2018). The most primitive products of the Permo-Carboniferous magmatism are mantle-derived mafic lavas dominantly present in Northern Europe; however, shallow-level processes in the crust (e.g., magmatic differentiation, anatexis and assimilation-fractional crystallization processes) resulted in more evolved felsic plutonic and volcanic rocks that are widespread in Europe (Wilson et al. 2004). The Upper Palaeozoic volcanic rocks are dominantly altered (K-metasomatized, hydrothermally altered and low-grade metamorphosed) and show significant variety in both petrographic 
features and geochemical characteristics. Regarding felsic volcanism, the zircon $\mathrm{U}-\mathrm{Pb}$ ages vary from $\sim 300 \mathrm{Ma}$ (Latest Carboniferous) to $\sim 245-240 \mathrm{Ma}$ (Latest PermianEarliest Triassic), suggesting a long-lasting magmatic activity during the PermoCarboniferous (Awdankiewicz 1999; Wilson et al. 2004; Paulick and Breitkreuz 2005; Vozárová et al. 2009, 2015, 2016; Słodczyk et al. 2018; Ondrejka et al. 2018).

Permian volcanic activity was recognized in several parts of the CarpathianPannonian region (e.g., Lelkes-Felvári and Klötzli 2004; Haas et al. 2008; Vozárová et al. 2009, 2015, 2016, Ondrejka et al. 2018). During the formation of the Pannonian Basin in the Early Miocene, two terranes got into juxtaposition creating the basement of the basin (Haas et al. 1999). Both the European-derived Tisia Terrane (Tisza Mega-unit) and the ALCAPA Terrane (ALCAPA Mega-unit, showing southern-Alpine affinity) bear the signs of the Permo-Carboniferous magmatism; however, there is limited petrographic, geochemical or geochronological information about it. Permian rhyolitic ignimbrites and mafic-intermediate (basalt and subordinate andesite) lavas are exposed in the centralwestern part of the Apuseni Mountains, Romania (Nicolae et al. 2014; Fig. IV.1/a), within the largest outcrop of the Tisza Mega-unit (Tisza MU) and also in the Hronicum (Central Western Carpathians, Vozár 1997; Dostal et al. 2003). In the western part of the Tisia Terrane, the only outcrop of these formations is known in the western part of the Mecsek Mts (Gyürüfü and Dinnyeberki area, Fig. IV.1/b; Szederkényi 1962; Barabásné Stuhl 1988; Hidasi et al. 2015; Szemerédi et al. 2016), but several deep boreholes, associated with the previous uranium ore exploration work, pierced such lithologies (Fig. IV.1/b). Permian felsic volcanic rocks are also known in the ALCAPA Mega-unit (North-West Hungary), dominantly by boreholes (e.g., well Kékkút-4; Lelkes-Felvári and Klötzli 2004; Fig. IV.1/a) and also as dykes within a crystalline limestone quarry near the village of Polgárdi (Fig. IV.1/a).

The age of these occurrences was basically considered on stratigraphic ground. Most of the former radiometric (K-Ar) datings failed to demonstrate their Permian age due to the subsequent diagenetic, metamorphic and/or metasomatic influence. The only Permian zircon U-Pb age was published in the ALCAPA Mega-unit (ALCAPA MU) by Lelkes-Felvári and Klötzli (2004), which placed the silicic volcanism to the Early Permian at 291.4 \pm 4.7 Ma. This volcanic episode was also recorded by a detrital zircon age component (279 $\pm 3 \mathrm{Ma}$ ) of Miocene sediments of the region (Kelemen et al. 2017).

The major goal of this study is to report new petrographic observations, geochemical (whole-rock analysis including major and trace elements) and 

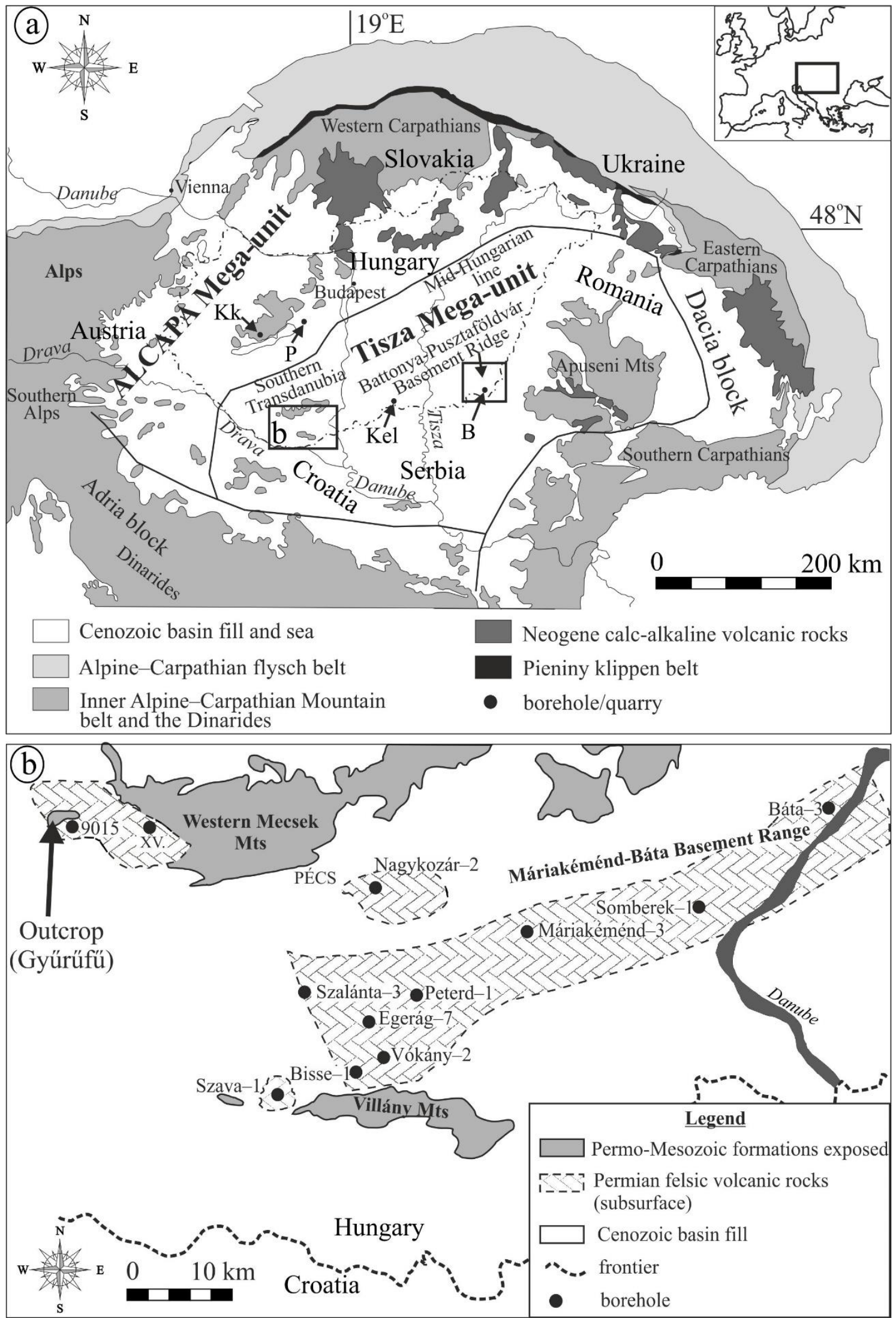

Figure IV.1 a Tectonic sketch of the Carpathian-Pannonian region indicating the subsurface contour of the mega-units. b Position of the studied Permian felsic volcanic rock outcrop and the boreholes of Southern Transdanubia, Hungary. Map base is modified after Szemerédi et al. (2017). B Battonya, Kel Kelebia, Kk Kékkút, $P$ Polgárdi 
geochronological (zircon $\mathrm{U}-\mathrm{Pb}$ ages) data to summarize our knowledge on the Permian volcanic activity in the Pannonian Basin. Our study covers the few outcrops and all available subsurface occurrences mainly from the Tisza MU. We further correlate these rocks with other Permo-Carboniferous felsic volcanic rocks of Central Europe (Apuseni Mts, Western Carpathians, NE Germany, Intra-Sudetic Basin).

\subsection{Geological background}

The Pannonian Basin is a Neogene basin located in eastern Central Europe. Its preNeogene basement consists of two mega-units, the Tisza MU and the ALCAPA MU of different geological history. The Tisza MU forms the basement of the Pannonian Basin south of the Mid-Hungarian line and crops out in two main areas in Southern Transdanubia that are the Mecsek and the Villány Mts (Fig. IV.1). The pre-Neogene basement of the area is known by several boreholes done for uranium ore and hydrocarbon exploration work (Szederkényi et al. 2013). Based on the Alpine evolution of the rocks three main facies zones, the so-called Mecsek, Villány-Bihor and BékésCodru Units are distinguished within the Tisza MU (Szederkényi et al. 2013). Permian felsic volcanic rocks showing similar petrographic features appear in all the three Alpine zones and are collectively named Gyürüfü Rhyolite Formation in the Hungarian lithostratigraphical literature, after the locality of the single outcrop (Fig. IV.1/b), near the village of Gyürüfü in the Western Mecsek Mts (Fülöp 1994). The most important information (outcrop/boreholes, base, top, thickness, radiometric age data and facies zones) about the Permian volcanic rocks in Hungary are summarized in Table IV.1. Previous papers and drilling reports (Fazekas 1978; Barabásné Stuhl 1988; Császár 2005) outlined the main regions, where this formation is present (Fig. IV.1). These are (1) the Western Mecsek Mts as part of the Mecsek Unit; (2) the Máriakéménd-Báta Basement Range (Máriakéménd-Báta BR) and (3) the northern foreland of the Villány Mts as parts of the Villány-Bihor Unit; (4) the Battonya-Pusztaföldvár Basement Ridge (BattonyaPusztaföldvár BR) and (5) the Kelebia area belonging to the Békés-Codru Unit.

Most of the interpretations (Szederkényi 1962; Fazekas 1978; Barabásné Stuhl 1988) considered rhyolitic-dacitic lava flows in the drillings and outcrops; however, recently, occurrences in the Western Mecsek Mts were reinterpreted as of pyroclastic origin (Hidasi et al. 2015; Szemerédi et al. 2016). In this area, the small unique outcrop between the villages of Gyürüfü and Dinnyeberki is represented by rhyolitic ignimbrites 
(Szemerédi et al. 2016) and numerous boreholes penetrated pyroclastic rocks, as well (Fig. IV.1/b). Here, the maximum thickness of the formation is $144.1 \mathrm{~m}$. In the Máriakéménd-Báta BR, the Gyürüfü Rhyolite was documented by 4 wells (Fig. IV.1/b) having a maximum thickness of $142.9 \mathrm{~m}$ (borehole Somberek-1). In the northern foreland of the Villány Mts, a complex system of the Permian volcanic rocks (pyroclastic rocks and lavas) is known by deep drillings (Bisse-1, Egerág-7, Peterd-1, Szalánta-3, Szava-1 and Vókány-2; Fig. IV.1/b) generally having hundreds of meters in thickness (e.g., Bisse1: $428 \mathrm{~m}$, Egerág-7: $831 \mathrm{~m}$ and Vókány-2: $461 \mathrm{~m}$ ). At the Battonya-Pusztaföldvár BR, eastern Pannonian Basin, the Permian volcanic rocks (dominantly rhyolitic ignimbrites; Szemerédi et al. 2020b) are penetrated by $c a$. 50 deep petroleum exploration drillings, their greatest thickness being $\sim 400$ meters (borehole Tótkomlós-I). In the Kelebia area (Fig. IV.1/a), the Permian volcanic rocks are known by 4 boreholes and were affected by Alpine very low-grade metamorphism (Császár 2005; Raucsik et al. 2016).

Upper Paleozoic felsic volcanic rocks also occur in the ALCAPA MU, in the region of Central Transdanubia (Fig. IV.1/a), and are known by several boreholes, dominantly in the Balaton Highland (Fülöp 1990; Table IV.1). The most studied deep borehole of the area is the well Kékkút-4 (Fig. IV.1/a) that penetrated volcanic rocks with a thickness of $630 \mathrm{~m}$. Strongly altered porphyric lavas of the drilling show dacitic composition and are underlain by Lower Devonian limestones and overlain by Upper Permian continental red beds (Fülöp 1990; Lelkes-Felvári and Klötzli 2004). Dykes having similar composition are also known in the metamorphic limestone quarry near Polgárdi (Fig. IV.1/a), suggesting an extensive volcanic activity during the Permian. The volcanic activity of the ALCAPA MU is considered to be Early Permian and referring to the most significant borehole these rocks are collectively named Kékkút Dacite or "Kékkút quartz-porphyry" in the Hungarian geological literature.

Previous K-Ar age data are dominantly Triassic (Balogh and Kovách 1973) which contradicts their stratigraphic position (Table IV.1). The only radiometric age data (zircon $\mathrm{U}-\mathrm{Pb}$ ) proving Permian age for the volcanic activity is published from a borehole sample (Kékkút-4, 865 m; Lelkes-Felvári and Klötzli 2004) of the ALCAPA MU.

Table IV.1 Most important information about the studied Permian felsic volcanic rocks of the Tisza Mega-unit and the ALCAPA Mega-unit, Hungary. The selected 20 outcrop/boreholes of recent study with whole-rock geochemical data are underlined. Pale grey: Mecsek Unit, grey: Villány-Bihor Unit, dark grey: Békés-Codru Unit 


\begin{tabular}{|c|c|c|c|c|c|c|}
\hline & \multicolumn{5}{|c|}{ Tisza Mega-unit (Tisia Terrane) } & \multirow{3}{*}{$\begin{array}{l}\text { ALCAPA } \\
\text { Mega-unit } \\
\text { Central } \\
\text { Transdanubia } \\
\text { Balaton } \\
\text { Highland } \\
\text { (+Polgárdi } \\
\text { quarry) }\end{array}$} \\
\hline & \multicolumn{3}{|c|}{ Southern Transdanubia } & \multicolumn{2}{|c|}{ Eastern Pannonian Basin } & \\
\hline & $\begin{array}{l}\text { Western } \\
\text { Mecsek Mts }\end{array}$ & $\begin{array}{l}\text { Máriakéménd } \\
\text {-Báta } \\
\text { Basement } \\
\text { Range }\end{array}$ & $\begin{array}{l}\text { Northern } \\
\text { foreland of the } \\
\text { Villány Mts }\end{array}$ & $\begin{array}{l}\text { Battonya- } \\
\text { Pusztaföldvár } \\
\text { Basement } \\
\text { Ridge }\end{array}$ & $\begin{array}{l}\text { Kelebia } \\
\text { area }\end{array}$ & \\
\hline $\begin{array}{l}\text { Outcrop/ } \\
\text { Boreholes }\end{array}$ & $\begin{array}{l}\frac{\text { outcrop }}{\text { (Gyürüfü), }} \\
\text { exploration } \\
\frac{\text { borehole No. }}{\text { XV, }} \\
\underline{\text { Dinnyeberki }} \\
9015,9018, \\
\text { Gyürüfü } 9007, \\
9008,9012\end{array}$ & $\begin{array}{c}\text { Báta-3, } \\
\text { Máriakéménd- } \\
\underline{3}, \text { Nagykozár- } \\
2, \text { Somberek-1 }\end{array}$ & $\begin{array}{c}\text { Bisse-1, Peterd- } \\
\text { 1, Szava-1, } \\
\text { Vókány-2, } \\
\text { Egerág-7, } \\
\text { Szalánta-3 }\end{array}$ & $\begin{array}{l}c a .50 \\
\text { boreholes near } \\
\text { Nagyszénás, } \\
\text { Pusztaföldvár, } \\
\text { Tótkomlós, } \\
\text { Végegyháza, } \\
\text { Pitvaros and } \\
\text { Battonya (5 } \\
\text { samples) }\end{array}$ & $\begin{array}{l}\text { boreholes } \\
\text { near the } \\
\text { village of } \\
\text { Kelebia } \\
\text { including } \\
\text { Kelebia-7, } \\
\text { Kelebia-11, } \\
\text { Kelebia-12, } \\
\text { Kelebia-22 }\end{array}$ & $\begin{array}{l}\text { boreholes in the } \\
\text { Balaton } \\
\text { Highland } \\
\text { including } \\
\text { (Kékkút-4, } \\
\text { Tótvázsony-1 } \\
\text { etc.) and dykes } \\
\text { in a crystalline } \\
\text { limestone } \\
\text { quarry } \\
\text { (Polgárdi) }\end{array}$ \\
\hline Base & $\begin{array}{l}\text { Korpád } \\
\text { Sandstone } \\
\text { (Lower } \\
\text { Permian) }\end{array}$ & $\begin{array}{l}\text { Korpád } \\
\text { Sandstone } \\
\text { (Lower } \\
\text { Permian) or } \\
\text { metamorphic }\end{array}$ & $\begin{array}{l}\text { Korpád } \\
\text { Sandstone } \\
\text { (Lower } \\
\text { Permian) or not } \\
\text { drilled }\end{array}$ & $\begin{array}{l}\text { Korpád } \\
\text { Sandstone } \\
\text { (Lower } \\
\text { Permian) or } \\
\text { metamorphic/ } \\
\text { Variscan } \\
\text { granites }\end{array}$ & $\begin{array}{l}\text { Korpád } \\
\text { Sandstone } \\
\text { (Lower } \\
\text { Permian) }\end{array}$ & $\begin{array}{l}\text { Kékkút } \\
\text { Limestone } \\
\text { (Lower } \\
\text { Devonian) }\end{array}$ \\
\hline Top & $\begin{array}{l}\text { Cserdi } \\
\text { Conglomerate } \\
\text { (Middle } \\
\text { Permian) }\end{array}$ & $\begin{array}{l}\text { Cserdi } \\
\text { Conglomerate } \\
\text { (Middle } \\
\text { Permian) }\end{array}$ & $\begin{array}{l}\text { Jakabhegy } \\
\text { Sandstone } \\
\text { (Lower } \\
\text { Triassic) }\end{array}$ & $\begin{array}{l}\text { Jakabhegy } \\
\text { Sandstone } \\
\text { (Lower } \\
\text { Triassic) }\end{array}$ & $\begin{array}{l}\text { Jakabhegy } \\
\text { Sandstone } \\
\text { (Lower } \\
\text { Triassic) }\end{array}$ & $\begin{array}{l}\text { Balatonfelvidék } \\
\text { Sandstone } \\
\text { (Upper } \\
\text { Permian) }\end{array}$ \\
\hline $\begin{array}{l}\text { Maximum } \\
\text { thickness } \\
\text { (borehole) }\end{array}$ & $\begin{array}{l}144.1 \mathrm{~m} \\
\text { (exploration } \\
\text { borehole No. } \\
\mathrm{XV} \text { ) }\end{array}$ & $\begin{array}{l}142.9 \mathrm{~m} \\
(\text { Somberek-1) }\end{array}$ & $\begin{array}{l}831.0 \mathrm{~m} \\
\text { (Egerág-7) }\end{array}$ & $\begin{array}{l}400 \mathrm{~m} \\
\text { (Tótkomlós-I) }\end{array}$ & $\begin{array}{l}\sim 40 \mathrm{~m} \\
\text { (based on } \\
\text { all } \\
\text { boreholes) }\end{array}$ & $\begin{array}{l}630.0 \mathrm{~m} \\
\text { (Kékkút-4) }\end{array}$ \\
\hline $\begin{array}{l}\text { Published } \\
\text { radiometric } \\
\text { age data } \\
\text { (*Barabásné } \\
\text { Stuhl 1988; } \\
\text { **Lelkes- } \\
\text { Felvári and } \\
\text { Klötzli 2004) }\end{array}$ & $\begin{array}{l}199.2 \pm 7.5 \\
\text { Ma (Gyürüfü } \\
\left.9018, \mathrm{~K}-\mathrm{Ar}^{*}\right)\end{array}$ & $\begin{array}{l}231.0 \pm 8.7 \\
\text { Ma } \\
(\text { Somberek-1, } \\
\text { K-Ar*) } \\
216.0 \pm 8.2 \\
\text { Ma } \\
(\text { Somberek-1, } \\
\text { K-Ar*) } \\
198.4 \pm 7.5 \\
(\text { Nagykozár-2, } \\
\text { K-Ar*) } \\
221.9 \pm 8.4 \\
(\text { Máriakéménd } \\
-3, \text { K-Ar*) }\end{array}$ & $\begin{array}{l}240.2 \pm 9.0 \mathrm{Ma} \\
\text { (Egerág-7, K- } \\
\text { Ar*) } \\
240.6 \pm 9.0 \mathrm{Ma} \\
\text { (Vókány-2 K- } \\
\text { Ar*) } \\
240.2 \pm 9.0 \mathrm{Ma} \\
(\text { Szava-1, K- } \\
\text { Ar*) } \\
241.5 \pm 9.1 \mathrm{Ma} \\
(\text { Egerág-7, K- } \\
\text { Ar*) }\end{array}$ & & & $\begin{array}{l}291.4 \pm 4.7 \mathrm{Ma} \\
\text { (Kékkút-4, U- } \\
\left.\mathrm{Pb}^{* *}\right)\end{array}$ \\
\hline \multicolumn{7}{|l|}{ Notation } \\
\hline $\begin{array}{l}\text { Color in trace } \\
\text { element } \\
\text { diagrams } \\
\text { (REE, spider) }\end{array}$ & yellow-brown & green & red & blue & light blue & black \\
\hline
\end{tabular}




\subsection{Sampling and analytical methods}

In the Western Mecsek Mts, fresh hand specimens were collected from the outcrops between the villages of Dinnyeberki and Gyürüfü (Szemerédi et al. 2016). Boreholes exposing felsic volcanic rocks in Southern Transdanubia were drilled by the Mecsek Ore Mining Company during the second half of the twentieth century. Representative volcanic samples were provided by the company from boreholes Bisse-1, Egerág-7, Peterd-1, Szalánta-3, Szava-1 and Vókány-2. In addition, Permian volcanic rocks belonging to the collection of the Department of Petrology and Geochemistry, Eötvös Loránd University (Budapest) from drillings near the villages of Egerág, Peterd, Szava, Vókány, Máriakéménd and Somberek were also used for petrographic analyses. Several samples representing the Battonya-Pusztaföldvár BR and the Kelebia area were also selected from the core collection of the Department of Mineralogy, Geochemistry and Petrology, University of Szeged.

Petrographic observations were done at the Department of Mineralogy, Geochemistry and Petrology, University of Szeged using Brunel SP-300-P and Olympus BX41 polarizing microscopes. Modal compositions (vol\%) in the petrographic descriptions are estimations from thin sections.

A total of 20 samples were selected for bulk rock chemistry (Supplementary Tables IV.1-3). These specimens were powdered and analyzed at the Bureau Veritas Mineral Laboratories (AcmeLabs, Vancouver, Canada) by ICP-ES (major elements) and ICP-MS (trace elements including REE). Sample preparation included the splitting of 0.2 g sample for $\mathrm{LiBO}_{2} / \mathrm{Li}_{2} \mathrm{~B}_{4} \mathrm{O}_{7}$ fusion decomposition for ICP-ES and $0.2 \mathrm{~g}$ sample for ICPMS. Detection limits for major elements are $0.01-0.04 \mathrm{wt} \%$. The analytical accuracy was controlled using the internal geological reference materials STD SO-19 and QUARTZ_KRA (pure quartz). The accuracy was better than $\pm 1.5 \%$. The precision was verified by duplicated samples in each analytical set. During repeated measurements, it was better than $0.5 \%$. Loss on ignition (LOI) was determined by weight difference after $4 \mathrm{~h}$ ignition at $1000{ }^{\circ} \mathrm{C}$. For comparison, the major and/or trace element geochemistry of the analogous formations of the European Variscides were used from published papers.

Zircon $\mathrm{U}-\mathrm{Pb}$ geochronology were performed on $63-125 \mu \mathrm{m}$ zircon crystals concentrated by standard heavy mineral separation method (crushing, sieving, heavy liquid separation, magnetic separation and hand-picking). Zircon crystals were fixed on a double-side adhesive tape and embedded in a $25 \mathrm{~mm}$ diameter epoxy mounts. The 
crystal mounts were lapped by 2500 mesh $\mathrm{SiC}$ paper and polished by 9, 3 and 1 micron diamond suspensions. Cathodoluminescence mapping was done at the Department of Petrology and Geochemistry, Eötvös Loránd University, Budapest using an AMRAY 1830 scanning electron microscope equipped with a GATAN MiniCL. The in-situ U-Pb radiometric age determinations were performed for one sample (Gy-1, Gyürüfü outcrop) at the ETH, Zürich, Switzerland and five samples at the GÖochron Laboratories of GeorgAugust University, Göttingen, Germany by laser-ablation single-collector sector-field inductively coupled plasma mass spectrometry (LA-SF-ICP-MS). In Göttingen, a Thermo Scientific Element 2 mass spectrometer, while in Zürich a Thermo Scientific Element XR mass spectrometer were used, both coupled to a Resonetics Excimer laser ablation system. All age data presented here were obtained by single spot analyses with a laser beam diameter of $33 \mu \mathrm{m}$, a repetition rate of $5 \mathrm{~Hz}$ and an energy density of $2 \mathrm{~J} \mathrm{~cm}^{-}$ 2 and a crater depth of approximately $10 \mu \mathrm{m}$. Detailed parameters are listed in Electronic Supplementary Material IV.1.

The method employed for analysis in Göttingen is described in details by Frei and Gerdes (2009). Here, the data reduction is based on the processing of $c a .46$ selected time slices (corresponding $c a .13 \mathrm{~s}$ ) starting $c a .3 \mathrm{~s}$ after the beginning of the signal. If the ablation hit zones or inclusions with highly variable actinide concentrations or isotope ratios, then the integration interval was slightly resized or the analysis was discarded ( $1 \%$ of the spots). The individual time slices were tested for possible outliers by an iterative Grubbs test (applied at $P=5 \%$ level). This test filtered out only the extremely biased time slices, and in this way usually less than $2 \%$ of the time slices were rejected. Drift and fractionation corrections and data reductions were performed by an in-house software (UranOS; Dunkl et al. 2008).

In Zürich, we applied $40 \mathrm{~s}$ ablation duration and no common $\mathrm{Pb}$ correction, but integration intervals were set to exclude inclusions and common $\mathrm{Pb}$. Data were processed using Iolite 2.5 (Paton et al. 2010, 2011) and checked for apparent discordancy using VizualAge (Petrus and Kamber 2012).

In both laboratories, age calculation and quality control are based on the drift- and fractionation correction by standard-sample bracketing using GJ-1 zircon standard reference material (Jackson et al. 2004; "Primary SRM"). For further control the Plešovice, 91500, Temora and LG_0302 standard reference zircons (Wiedenbeck et al. 1995; Black et al. 2004; Sláma et al. 2008) were analysed as “Secondary SRM”. The age results of the reference materials were consistently within 2 SE of the published ID-TIMS 
values (see Electronic Supplementary Material IV.2). The concordia plots and age spectra were constructed and the ZircAge calculations were done by the software Isoplot/Ex 3.0 (Ludwig 2002) and IsoplotR (Vermeesch 2018). Measurements are considered discordant if the difference between the ${ }^{207} \mathrm{~Pb} /{ }^{235} \mathrm{U}$ and ${ }^{206} \mathrm{~Pb} /{ }^{238} \mathrm{U}$ age was larger than $10 \%$. Discordant ages arise from: common $\mathrm{Pb}$ contamination either from inclusions or cracks, recent $\mathrm{Pb}$-loss or measuring different age domains in the grain leading to mixed ages.

The total external error, estimated to be $\sim 1 \%$ for ${ }^{206} \mathrm{~Pb} /{ }^{238} \mathrm{U}$ ages, and is composed of the uncertainty from (1) the applied corrections, especially the down hole fractionation correction, (2) uncertainty of the decay constants, (3) lacking common $\mathrm{Pb}$ correction and (4) the uncertainty on the true ${ }^{206} \mathrm{~Pb} /{ }^{238} \mathrm{U}$ ratio of the primary standard GJ-1, and possible uncertainty from matrix effects.

Crystallization ages were calculated with $95 \%$ confidence and total uncertainties are given, including quadratically propagated external error as suggested in Horstwood et al (2016). The external error corrected ages (here considered as ages closest to volcanic eruptions) are reported in Table IV.2.

Table IV.2 Compilation of the zircon, in-situ geochronological results obtained on the Permian felsic volcanic rocks from the Tisza Mega-unit and the ALCAPA Mega-unit. ${ }^{a}$ Discordant and outlier data free concordia ages of IsoplotR except for Gy-1 which result stands for the youngest age component of the IsoplotR mixing model

\begin{tabular}{|c|c|c|c|c|c|}
\hline Sample name & $\begin{array}{l}\text { Concordant/All } \\
\text { spots }\end{array}$ & $\mathrm{Th} / \mathrm{U}(1 \mathrm{SD})$ & TuffZirc Age (Ma) & $\begin{array}{l}\text { IsoplotR } \\
\text { result }^{\mathrm{a}}(\mathrm{Ma})\end{array}$ & $\begin{array}{l}\text { Interpreted } \\
\text { eruption age } \\
\text { (with external } \\
\text { errors) }\end{array}$ \\
\hline \multicolumn{6}{|c|}{ Tisza Mega-unit (Tisia Terrane) } \\
\hline \multicolumn{6}{|c|}{ Western Mecsek Mts } \\
\hline Gy-1 & $39 / 45$ & $0.6 \pm 0.4$ & $267.4+0.6-1.4(17)$ & $266.8 \pm 0.2$ & $266.8 \pm 2.7$ \\
\hline \multicolumn{6}{|c|}{ Northern foreland of the Villány Mts } \\
\hline Szava-1 & $29 / 36$ & $0.6 \pm 0.3$ & $266.5+1.2-1.9(14)$ & $265.3 \pm 0.5$ & $265.3 \pm 2.7$ \\
\hline \multicolumn{6}{|c|}{ Battonya-Pusztaföldvár Basement Ridge } \\
\hline $\mathrm{BATR} / 1$ & $26 / 31$ & $0.4 \pm 0.1$ & $259.4+0.9-1.5(22)$ & $259.5 \pm 0.4$ & $259.5 \pm 2.6$ \\
\hline $\mathrm{BATR} / 2$ & $20 / 35$ & $0.4 \pm 0.1$ & $259.4+2.3-1.8(11)$ & $259.5 \pm 0.5$ & $259.5 \pm 2.6$ \\
\hline \multicolumn{6}{|l|}{ Kelebia area } \\
\hline Kel-7 & $32 / 36$ & $0.3 \pm 0.2$ & $263.7+2.4-0.7(19)$ & $263.4 \pm 0.5$ & $263.4 \pm 2.7$ \\
\hline \multicolumn{6}{|c|}{ ALCAPA Mega-unit (ALCAPA Terrane) } \\
\hline PR-1 & $18 / 35$ & $0.6 \pm 0.2$ & $281.5+2.9-0.6(20)$ & $281.0 \pm 0.5$ & $281.0 \pm 2.9$ \\
\hline
\end{tabular}

\subsection{Results and interpretations}

\subsubsection{Petrography}

In this chapter, the felsic volcanic rocks of the different outcrops and drillings are briefly described. Representative photomicrographs of the volcanic rocks are shown in Fig. IV.2 and Supplementary Figure IV.1. 


\subsubsection{Tisza Mega-unit (Tisia Terrane)}

Felsic rocks in Southern Transdanubia are dominantly greyish or brownish red/purple, massive, compacted lapilli tuffs, rich in $\mathrm{mm}-\mathrm{cm}$-sized flattened, deformed pumices and various poorly sorted, fragmented crystals (Fig. IV.2/a, b). The maximum length of the pumices is $80-90 \mathrm{~mm}$, and their elongation ratio is 5-90:1-20 (observed on hand specimens). The crystals (30-45 vol\%) are dominantly resorbed, subhedral quartz (10$20 \mathrm{vol} \%$, up to $5 \mathrm{~mm}$, Fig. IV.2/b) and altered (argillitized, sericitized or carbonatized), euhedral or subhedral feldspars (10-25 vol\%, dominantly potassium feldspar, subordinate plagioclase, up to $5 \mathrm{~mm}$, Fig. IV.2/a, c). At the northern foreland of the Villány Mts (borehole Peterd-1) pectinate, macroscopically iridescent K-feldspar (adularia) crystals are also present (Supplementary Figure IV.1/a, b). Mafic components are hematitized or chloritized biotite (1-5 vol\%, up to $2 \mathrm{~mm}$, Fig. IV.2/a, b, d) and strongly altered pyroxene ( $<1 \mathrm{vol} \%$, up to $2 \mathrm{~mm}$, Fig. IV.2/a and Supplementary Figure IV.1/b). As accessory minerals zircon (Supplementary Figure IV.1/a), apatite, rutile, monazite and xenotime were identified (Szemerédi et al. 2016). Some samples of the northern foreland of the Villány Mts (boreholes Egerág-7 and Szalánta-3) contain tourmaline and subhedral garnet crystals (Fig. IV.2/c; Szemerédi et al. 2017). The rocks are variably foliated (Fig. IV.2/a, b), the foliation being formed on altered, devitrified pumices and glass shards (50-200 $\mu \mathrm{m}$; Fig. IV.2/b, c, d) that are often replaced by clay minerals. Pumices contain high temperature crystallization domains on their margins and inside them (HTCD-s: axiolites, spherulites, Fig. IV.2/a; e.g., Breitkreuz 2013).

Pyroclastic rocks were also revealed at the eastern Pannonian Basin, however, some differences were found between them and the lapilli tuffs of S Transdanubia. Samples of the Battonya-Pusztaföldvár BR (Fig. IV.2/e) are crystal-poor (10-25 vol\%), massive, pumice-bearing lapilli tuffs that contain subhedral, resorbed, rarely euhedral quartz (10-15 vol\%, up to $3 \mathrm{~mm}$ ) and altered (argillitized, sericitized or carbonatized), euhedral or subhedral feldspar crystals (10-15 vol\%, dominantly potassium feldspar, subordinate plagioclase, up to $3 \mathrm{~mm}$ ). As mafic component rarely hematitized biotite (< 1 vol\%, up to $1 \mathrm{~mm}$ ), as accessory mineral zircon crystals are present. The samples dominantly contain flattened, devitrified pumices and sintered glass shards (Fig. IV.2/e); however, some of them shows felsitic, porphyric texture (lava-like appearance, Szemerédi et al. 2020b). 

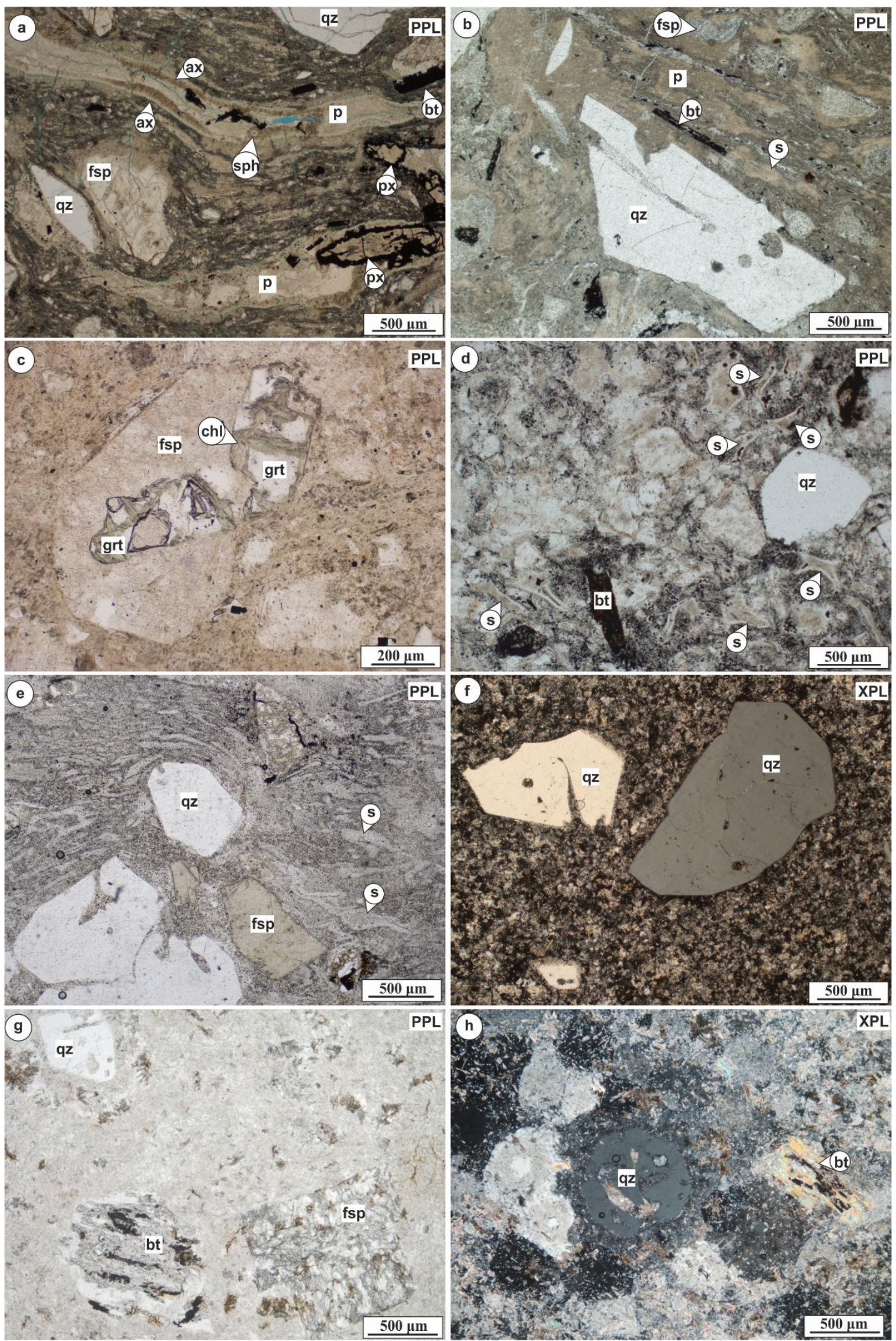
Figure IV.2 Photomicrographs of the Permian felsic volcanic rocks, Tisza Mega-unit and ALCAPA Mega-unit, Hungary: a Sample GYRFP, pyroclastite (Western Mecsek Mts, outcrop): parallel pumices with axiolites at the margins and spherulites inside them together with opaque pseudomorphs after pyroxene. b Sample Somberek-1, pyroclastite (Máriakéménd-Báta Basement Range, borehole): fragmented quartz, feldspar and biotite crystals in a welded ignimbrite. c Sample Szalánta-3, pyroclastite (northern foreland of the Villány Mts): subhedral, chloritized and fragmented garnet showing intergrowth with potassium feldspar. d Sample GYR K2, pyroclastite (Western Mecsek Mts, outcrop): X- and Yshaped glass shards in the matrix of a non-welded ignimbrite. e Sample ÁGK-1830, pyroclastite (Battonya-Pusztaföldvár Basement Ridge, borehole): subhedral quartz and feldspar crystals in a strongly welded ignimbrite. f Sample Vókány-2, lava (northern foreland of the Villány Mts, borehole): felsitic texture with subhedral, resorbed and fractured quartz crystals. g Sample Polgárdi, dyke (Central Transdanubia, Polgárdi quarry): porphyric plagioclase and pseudomorph after biotite with resorbed quartz. h Sample Polgárdi, dyke (Central Transdanubia, Polgárdi quarry): mosaic quartz and pseudomorph after biotite in mosaic quartz-sericite groundmass. $a x$ axiolite, $b t$ pseudomorph after biotite, $c h l$ chlorite, $f s p$ feldspar, grt garnet, $p$ altered pumice, $p x$ pseudomorph after pyroxene, $q z$ quartz, $s$ altered glass shard, sph spherulite, $P P L$ plane polarized light, $X P L$ crossed polars

Samples from the Kelebia area contain oriented, sericitized pumices (Supplementary Figure IV.1/c) in mm size and various broken, subhedral crystals (15-20 vol\% resorbed quartz, 10-15 vol\% plagioclase, 5 vol\% biotite and altered pyroxene) resembling to the lapilli tuffs of $S$ Transdanubia in their composition. However, these samples differ from the aforementioned volcanic rocks by having quartz crystals with undulose extinction and deformation lamellae and phenocrysts with symmetric quartz and K-mica pressure shadow (Supplementary Figure IV.1/d).

Felsic lavas were only drilled at the northern foreland of the Villány Mts (boreholes Egerág-7, Szalánta-3, Szava-1 and Vókány-2, Fig. IV.2/f). The porphyric (25$30 \mathrm{vol} \%$ ) rocks are dominated by subhedral, resorbed or fragmented quartz (10-15 vol\%, up to $5 \mathrm{~mm}$, Fig. IV.2/f), subhedral, altered (argillitized, sericitized or carbonatized) potassium feldspar and plagioclase (10-25 vol\%, up to $9 \mathrm{~mm}$ ). Mafic components are faded, hematitized or chloritized, fragmented biotite crystals (1-3 vol\%, up to $2 \mathrm{~mm}$ ). Accessory minerals are zircon, apatite and opaque phases. The textures are dominantly microholocrystalline or felsitic (Fig. IV.2/f), rarely relict perlitic, spherulitic or granophyric. Two sequences (boreholes Egerág-7 and Szalánta-3) contain more plagioclase than potassium feldspar and no porphyric quartz. In borehole, Szava-1 0.5-1 mm-sized clots were observed that dominantly contain zircon, apatite, opaque minerals, carbonate. and muscovite (Supplementary Figure IV.1/e, f).

\subsubsection{ALCAPA Mega-unit (ALCAPA Terrane)}

Felsic volcanic rocks from borehole Kékkút-4 are light greyish green lavas with quartz, plagioclase and strongly altered biotite in a fine-grained completely recrystallized matrix. The groundmass is built up by aggregate of quartz + albite; however, spherulithic textures 
also occur. At some borehole levels, irregular sericite patches, with rims rich in opaque $\mathrm{Fe}-\mathrm{Ti}$ oxides, could represent former glass shards. The mineralogical composition is dominated by fine-grained quartz, plagioclase (up to 1-2 cm, making up glomeroporphyric texture) and also fine-grained, hematitized biotite crystals. The accessory minerals are apatite, zircon and monazite, and as xenocrysts, altered, coarse garnet crystals occur. In some levels, pseudomorphs of chlorite after amphiboles are also

present. Potassium feldspars are absent probably due to the later replacement by albite (showing chess-board structure).

In the Polgárdi quarry, a $10 \mathrm{~m}$ thick, almost vertically oriented felsic dyke (Fig. IV.2/ g, h) cut the Devonian shallow marine limestone, without visible contact zone. Macroscopically, it is light yellowish or greenish grey/white, fine-grained, non-porous and homogeneous without any orientation. Few, well visible, isometric quartz phenocrysts $(\sim 0.5 \mathrm{~cm})$ and smaller insignificant rectangular feldspar pseudomorphs appear in it. The porphyric components (10-15 vol\%) are represented by three minerals: (1) strongly resorbed isometric quartz grains (4-5 vol\%, Fig. IV.2/g, h); (2) mostly euhedral feldspars (5-10\% vol\%, Fig. IV.2/g) altered totally to muscovite, calcite and few quartz with thin apatite needles; and (3) pseudomorphs of calcite and muscovite after biotite (Fig. IV.2/g, h). These latter grains contain few secondary opaque minerals and Ti oxides. Few original accessory minerals are the corroded dumpy apatite and zircon and the isometric opaque minerals. The groundmass is secondarily holocrystalline, and filled by mosaic texture of isometric equigranular quartz, overgrown partly on porphyric quartz grains. Few sericite, muscovite, calcite and siderite are scattered in and between quartz grains.

\subsubsection{Major and trace element geochemistry}

Major and trace, including rare earth elements, were analyzed for the selected samples of all the five Tisza MU regions and for the studied samples of the ALCAPA MU (Supplementary Tables IV.1-3). For geochemical comparison compositions of published Permo-Carboniferous felsic volcanic rocks of Central Europe (Apuseni Mts: Nicolae et al. 2014, Intra-Sudetic Basin: Awdankiewicz 1999; Northeast Germany: Paulick and Breitkreuz 2005; Western Carpathians: Vozárová et al. 2009, 2015, 2016); and Permian granites from the Apuseni Mts (Highiş massif, Pál-Molnár et al. 2008) are plotted in the 

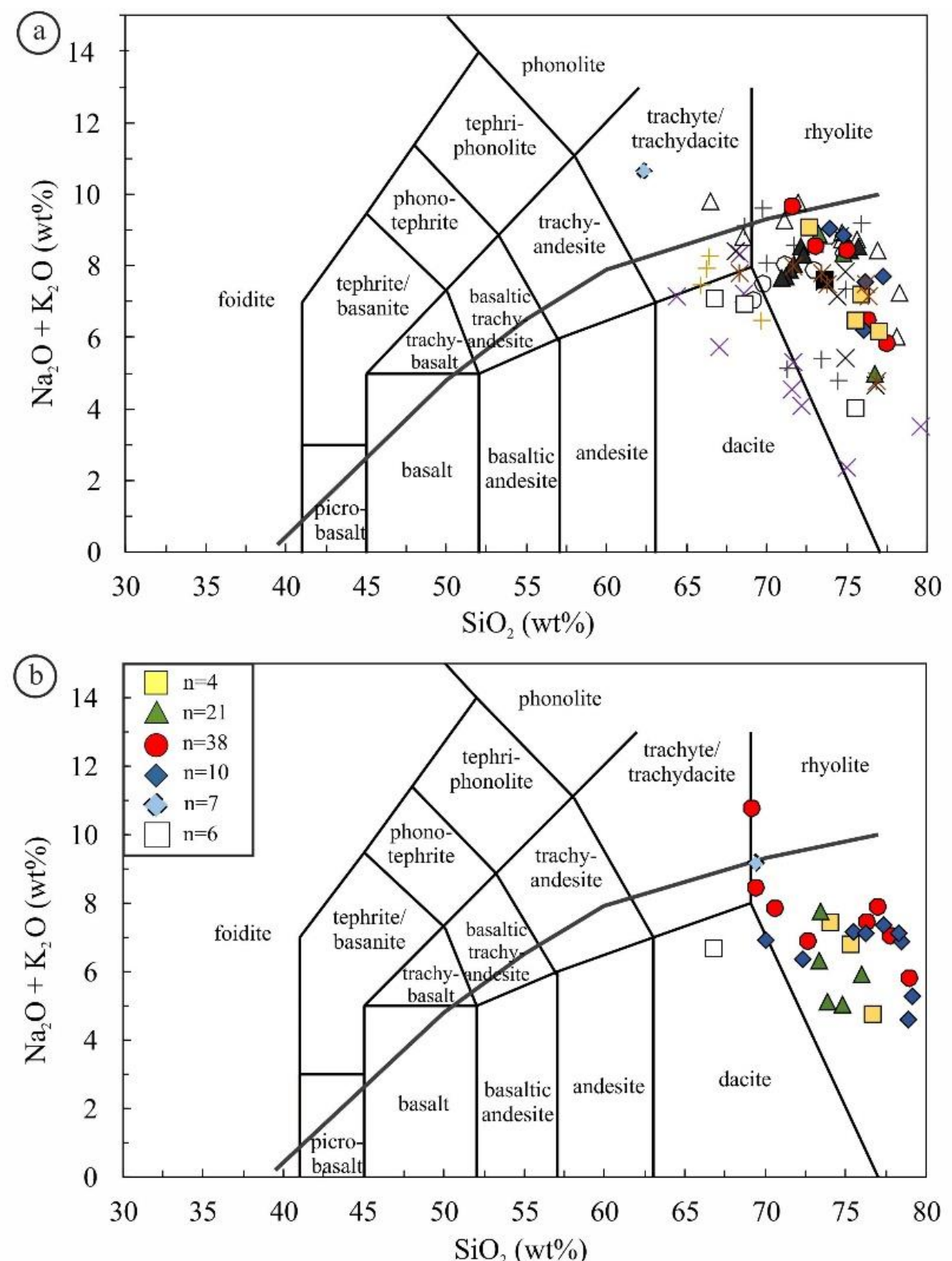

\begin{tabular}{|c|c|c|c|c|}
\hline & Tisza Mega-unit (HU) & $\square$ & $\begin{array}{c}\text { ALCAPA Mega-unit } \\
\text { (Central Transdanubia, HU) }\end{array}$ & $\triangle$ Intra-Sudetic Basin $(\mathrm{PL})$, younger \\
\hline$\square$ & Western Mecsek Mts & y & Apuseni Mts (RO), Tisza Mega-unit & Intra-Sudetic Basin (PL), older \\
\hline$\triangle$ & Máriakéménd-Báta BR & $\pi$ & P & + Northeast Germany (D) \\
\hline & Northern foreland of the Villany Mts & $x$ & Northern Gemeric Unit (SK) & A Highiș massif (RO), granites \\
\hline & Battonya Pusztaföldvár BR & $x$ & Southern Gemeric Unit (SK) & Average Palaeozoic felsic \\
\hline 仓 & Kelebia area & + & North & \\
\hline
\end{tabular}

Figure IV.3 Classification of the Permian volcanic rocks of the Tisza Mega-unit, the ALCAPA Mega-unit, Hungary and the analogous formations of the European Variscides in total alkali silica (TAS) diagrams (Le Maitre et al. 1989), based on new (a) and archive (b) geochemical data (Fazekas 1978; Barabásné Stuhl 1988; Fülöp 1990, 1994) with the number of the previous geochemical analyses $(n)$. Comparative data derive from the following authors: Apuseni Mts: felsic volcanic rocks (Nicolae et al. 2014); Northern Gemeric Unit: rhyolites-dacites (Vozárová et al. 2015); Southern Gemeric Unit: rhyolites (Vozárová et al. 2009); Northern Veporic Unit: volcanic rocks and tonalite dyke (Vozárová et al. 2016); Intra-Sudetic Basin: felsic rocks, younger and older volcanic suites (Awdankiewicz 1999); Northeast Germany: rhyodacites (Paulick and Breitkreuz 2005); Highiş massif, Apuseni Mts: Păuliş Granites (Pál-Molnár et al. 2008); Average Palaeozoic felsic volcanic rock composition: Condie (1993) 
geochemical diagrams. They are completed with the average Palaeozoic felsic volcanic rock composition summarized by Condie (1993).

In the total alkali-silica (TAS) diagram (Fig. IV.3) based on the new and archive geochemical data (Fazekas 1978; Barabásné Stuhl 1988), most of the samples fall into the rhyolite field with 71.6-77.2 wt\% $\mathrm{SiO}_{2}$ and variable alkali contents (4.0-10.7 wt\%). There is one sample representing the Kelebia area that plots in the trachydacite field and another one from the ALCAPA MU (Kékkút-4 borehole) is dacite according to its major element composition. In the $\mathrm{Zr} / \mathrm{TiO}_{2}$ vs. $\mathrm{Nb} / \mathrm{Y}$ diagram (Fig. IV.4), since based on trace elements, that are less sensitive for secondary processes, most samples plot in the rhyodacite/dacite and in the rhyolite fields with sub-alkaline character $(\mathrm{Nb} / \mathrm{Y}<0.6)$. In this diagram three outlier samples (Máriakéménd-3, Vókány-2 representing the Tisza MU and the Polgárdi sample representing the ALCAPA MU) fall in the trachyandesite field.

The chondrite-normalized rare earth element (REE) diagrams (Fig. IV.5) show different patterns for the samples of the Tisza MU (Fig. IV.5/a) and the ALCAPA MU (Fig. IV.5/b). REE patterns of the studied samples of the Tisza MU are dominantly

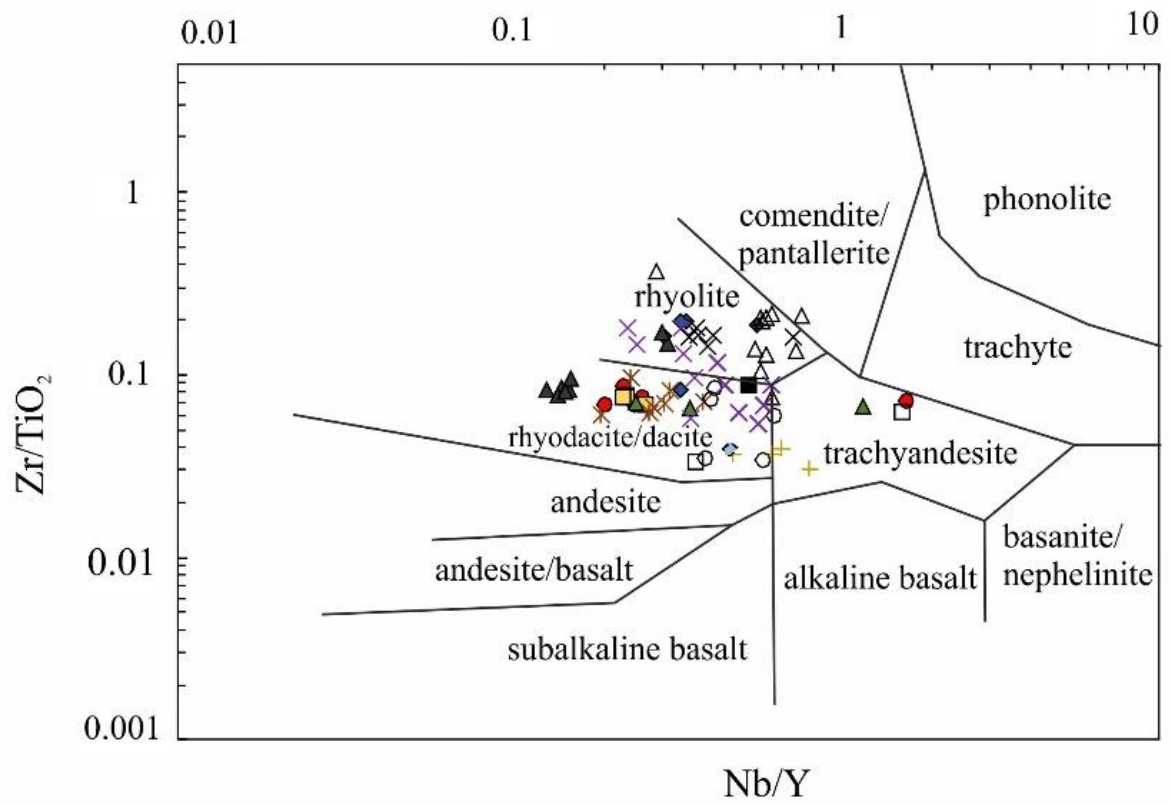

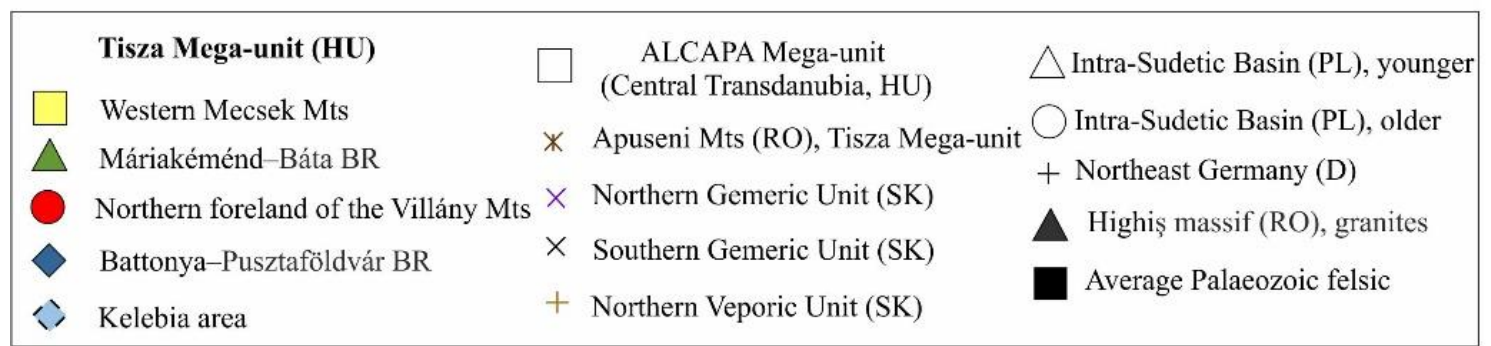

Figure IV.4 Classification of the studied Permian volcanic rocks of the Tisza Mega-unit, the ALCAPA Mega-unit, Hungary and the analogous formations of the European Variscides in the $\mathrm{Zr} / \mathrm{TiO}_{2} \mathrm{vs}$. $\mathrm{Nb} / \mathrm{Y}$ diagram (Winchester and Floyd 1977). The references of the comparative data are the same as those in Fig. IV.3 

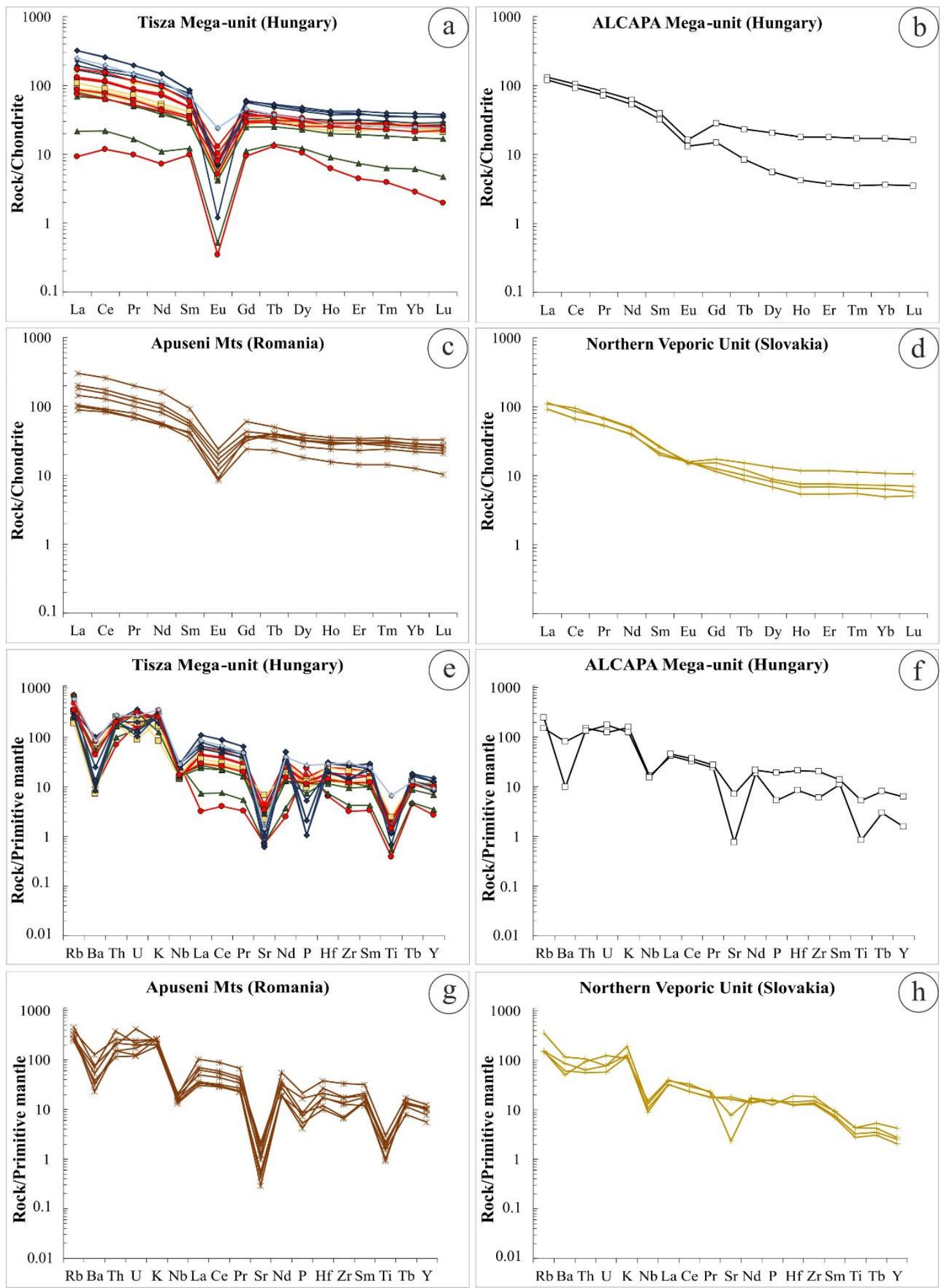

Figure IV.5 Chondrite-normalized rare earth element (REE) patterns and multi-element spider diagrams (Sun and McDonough 1989) of the Permian volcanic rocks of the Tisza Mega-unit, the ALCAPA Mega-unit, Hungary and two of the analogous formations of the European Variscides (Apuseni Mts, Romania and Northern Veporic Unit, Slovakia; Nicolae et al. 2014; Vozárová et al. 2016). The latter play important role in the regional correlation (see details in "Geochronology and correlation"). Note fractionated light (L)REE, negative Eu anomaly and nearly flat heavy (H)REE pattern. The symbols are the same as those in Fig. IV.3

parallel except for the two outlier samples (Máriakéménd-3, Vókány-2). They usually display enriched light $\left(\mathrm{LaN}_{N} / \mathrm{Sm}_{N}=2.4-3.8\right)$ and near-flat heavy $\mathrm{REE}\left(\mathrm{Gd}_{\mathrm{N}} / \mathrm{Yb}_{\mathrm{N}}=1.2-1.7\right)$ 
patterns with variously deep negative Eu anomaly $\left(\mathrm{Eu} / \mathrm{Eu}^{*}=0.0-0.3\right.$; Supplementary Tables IV.1 and IV.2). The values of REE fractionation $\left(\mathrm{La}_{N} / \mathrm{Yb}_{\mathrm{N}}\right)$ change from 3.4 to 9.2. On the other hand, REE patterns of the samples of the ALCAPA MU show slightly higher enrichment in both LREEs $\left(\mathrm{La}_{\mathrm{N}} / \mathrm{Sm}_{\mathrm{N}}=3.3\right.$ and 3.8) and HREEs (Kékkút-4 sample: $\left.\mathrm{Gd}_{\mathrm{N}} / \mathrm{Yb}_{\mathrm{N}}=4.1\right)$. However, their negative $\mathrm{Eu}$ anomaly is markedly less significant $\left(\mathrm{Eu} / \mathrm{Eu}^{*}=0.5\right.$ and 0.6; Supplementary Table IV.3) and the Polgárdi sample is depleted in HREEs $\left(\mathrm{Gd}_{N} / \mathrm{Yb}_{\mathrm{N}}=1.7\right)$. Besides the difference in their Eu anomaly, samples of the Tisza MU show higher enrichment in all the REEs than the samples of the ALCAPA MU show in general. In multi-element spider diagrams (Fig. IV.5), the samples of the Tisza MU (Fig. IV.5/e) are characterized by enrichment in Rb, K, Th and $\mathrm{U}$ and depletion in $\mathrm{Ba}, \mathrm{Nb}, \mathrm{Sr}, \mathrm{P}$ and Ti. The two outlier samples (Vókány-2, Máriakéménd-3) have remarkably different REE concentrations with extremly low $\Sigma$ REE values (22 and 36, respectively) and they show relative depletion in other immobile elements (Ti, Y, Zr), too. The samples from the ALCAPA MU (Fig. IV.5/f) differ from the volcanic rocks of the Tisza MU by showing no depletion in $\mathrm{P}$ and slighter depletion in Ti. The Polgárdi sample also shows relative depletion to the Kékkút core sample not only in HREEs, but also in immobile elements (Hf, Sm, Ti, Y). All samples show enrichment in $\mathrm{Rb}$ and $\mathrm{Th}$ relative to $\mathrm{Ba}$.

\subsubsection{Geochronology}

All studied zircons (Electronic Supplementary Material IV.3) show weak cathodoluminescence intensity and badly developed oscillatory zoning. 31-45 spots were analyzed in the 6 samples representing the 5 studied areas (Table IV.2; Electronic Supplementary Material IV.2). The laser ablation spots are placed mostly in the mantle parts of zircon crystals avoiding cracks and inclusions. The data were filtered out, as they give more than $10 \%$ discordance between ${ }^{206} \mathrm{~Pb} /{ }^{238} \mathrm{U}$ and ${ }^{207} \mathrm{~Pb} /{ }^{235} \mathrm{U}$ ages. The remained dates usually give large age ranges, suggesting the presence of older cores and/or possible $\mathrm{Pb}$ loss. For interpretations, we use the ${ }^{206} \mathrm{~Pb} /{ }^{238} \mathrm{U}$ ages, which are less influenced by small amounts of common $\mathrm{Pb}$ and are calculated from higher intensities of daughter isotopes than in case of ${ }^{207} \mathrm{~Pb} /{ }^{235} \mathrm{U}$ and ${ }^{208} \mathrm{~Pb} /{ }^{232} \mathrm{Th}$ ages. They have an average $2 \mathrm{~s}$ uncertainity between 1.5 and $2.4 \%$. The $\mathrm{Th} / \mathrm{U}$ ratios within samples usually do not give any systematic relation with the ${ }^{206} \mathrm{~Pb} /{ }^{238} \mathrm{U}$ ages. 
We applied the TuffZirc Age algorithm of ISOPLOT (Ludwig 2002) on the ${ }^{206} \mathrm{~Pb} /{ }^{238} \mathrm{U}$ ages for selecting the youngest coherent age group, which we may consider as ages closest to the volcanic eruption ages of the samples. However, as the analysed zircon crystals have not passed the annealing procedure (Mattinson 2005) suggested by, e.g., von Quadt et al. (2016) and Sliwinski et al. (2017), the obtained youngest age components can be skewed to younger ages by unidentified $\mathrm{Pb}$-loss effected data. We also approached the eruption ages using IsoplotR (Vermeesch 2018), which resulted similar concordia or youngest peak ages (Table IV.2; Electronic Supplementary Material IV.4).

\subsubsection{Tisza Mega-unit (Tisia Terrane)}

From the Western Mecsek Mts (Gyürüfü outcrop), 44 spot analyses prove to be concordant out of the 50 analyzed and they give $0.6 \pm 0.4$ (1 SD) average $\mathrm{Th} / \mathrm{U}$ ratio. The TuffZirc Age algorithm selects 17 date for the youngest coherent age $(267.4+0.6$ and 1.4 Ma; Fig. IV.6/a) excluding 15 older single spot ages, which are possibly affected by the incorporation of much older cores. The IsoplotR concordia age calculation (Electronic Supplementary Material IV.4) also suggests strongly overdispersed dates that may have geological meaning, i.e., they refer to mixing ages between young (near eruption) and old antecrystic or xenocrystic cores or crystals parts. Such age mixing can be resolved by the mixing model calculation implemented in IsoplotR and the youngest age component was accessed by the younger distinct age of a two component mixing. The youngest age component integrate $80 \%$ of the selected data and gives $266.8 \pm 0.2 \mathrm{Ma}$. The interpreted eruption age of this sample is $266.8 \pm 2.7$ Ma taking into account the external errors (Table IV.2).

The northern foreland of the Villány Mts is represented by the Szava-1 sample. In this sample, 29 zircon spots out of 36 give concordant dates, which vary between 580 and $217 \mathrm{Ma}$, with mean $\mathrm{Th} / \mathrm{U}$ ratios of $0.6 \pm 0.3$ (1 SD). Fourteen ages give a coherent group referring to $266.5+1.2-1.9$ Ma crystallization age (Fig. IV.6/b), the 8 younger dates might be affected by $\mathrm{Pb}$-loss and 4 data give much older crystallization dates, i.e., 580 $367 \mathrm{Ma}$. These oldest, outlier ages refer to spots which are either cores or show different CL images than most of the crystals. Concordia age calculations by IsoplotR resulted $265.3 \pm 0.5 \mathrm{Ma}(n=17)$ using outlier (outliers were selected by the modified Chauvenet outlier detection criterion of IsoplotR) and discordant free datagroup (Electronic 
Supplementary Material IV.4). The interpreted eruption age of this sample is $265.3 \pm 2.7$ Ma taking into account the external errors (Table IV.2).

From the Battonya-Pusztaföldvár BR, two samples were dated (BATR/1 and BATR/2), representing the Tótkomlós-K-3 borehole in the depth of 1669-1674 m. Concordant ages are calculated for 26 and 20 spots out of the analyzed 31 and 35 for BATR/1 and BATR/2 samples, respectively. In both cases, the zircons have Th/U ratios around $0.4 \pm 0.1$ ( $1 \mathrm{SD})$. BATR/1 sample has a weighted mean age of $259.6 \pm 1.1 \mathrm{Ma}$ with a MSWD of 2.1. The TuffZirc Age of this sample gives similar $259.4+0.9-1.5 \mathrm{Ma}$ taking 22 spot analyses (Fig. IV.6/c). BATR/2 sample gives identical TuffZirc Age of $259.4+2.3-1.8 \mathrm{Ma}$ (Fig. IV.6d) to BATR/1 suggesting their common formation age
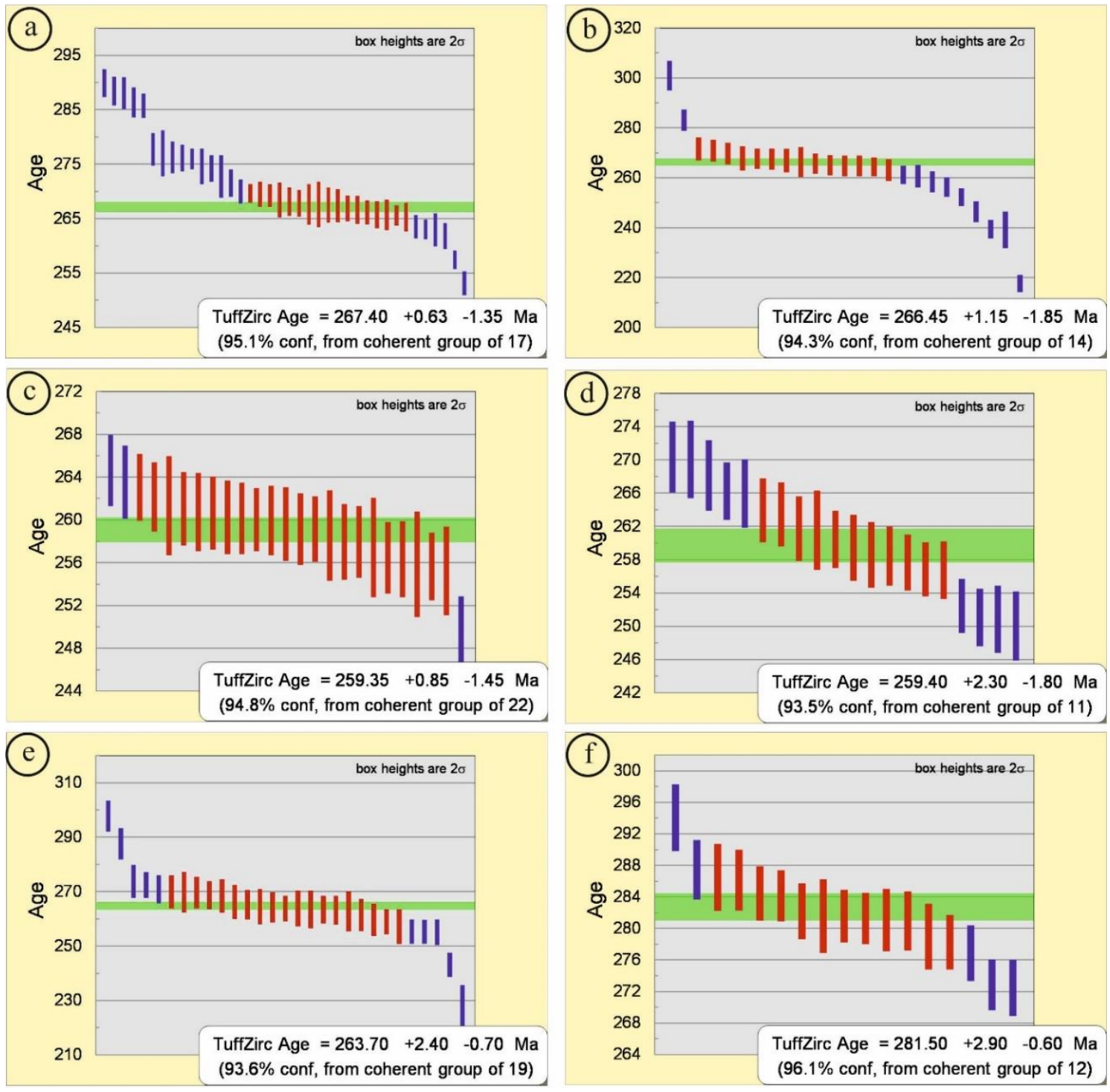

Figure IV.6 Results of the zircon U-Pb geochronology of the Permian volcanic rocks. The TuffZirc algorithm (Ludwig 2002) was applied in order to identify the mean age of the the youngest coherent age component. a Gy-1 sample (Western Mecsek Mts, outcrop), b Szava-1 sample (northern foreland of the Villány Mts, borehole), c, d BATR/1 and BATR/2 samples (Battonya-Pusztaföldvár Basement Ridge, borehole), e Kelebia-7 sample (Kelebia area, borehole), f PR-1 sample (Polgárdi quarry, dyke) 
and eruptive unit, although using much less useful data (11). Concordia age calculations by IsoplotR resulted $259.5 \pm 0.4 \mathrm{Ma}(n=22)$ and $259.5 \pm 0.5 \mathrm{Ma}(n=20)$ using outlier and discordant free datagroups (Electronic Supplementary Material IV.4). The interpreted eruption age of this two samples is $259.5 \pm 2.6$ Ma taking into account the external errors (Table IV.2).

In the Kelebia-7 borehole, sample 36 spots were targeted and 32 give concordant ages, with two younger outliers. Th/U ratios are around $0.3 \pm 0.2(1 \mathrm{SD})$. TuffZirc Age is $263.7+2.4-0.7$ Ma calculated from 19 dates (Fig. IV.6/e), which is nearly the same as the weighted mean age $(263.5 \pm 2.4 \mathrm{Ma})$ of 25 dates excluding four outliers, with an MSWD 4.5. Four younger dates were ruled out by the algorithm which is in accordance with the fact that these spots have the highest $U$ contents and, therefore, possibly prone to the most $\mathrm{Pb}$-loss. Three spots yielded much older ages, giving evidence for the inheritance of crystals during magma evolution in the crust. IsoplotR resulted $263.4 \pm 0.5$ $\mathrm{Ma}(n=24)$ as concordia age for the outlier and discordant-free datagroup (Electronic Supplementary Material IV.4). The interpreted eruption age of this sample is $263.4 \pm 2.7$ Ma taking into account the external errors (Table IV.2).

\subsubsection{ALCAPA Mega-unit (ALCAPA Terrane)}

PR-1 sample is from the Polgárdi outcrop, representing the only known surface occurrence of Permian rhyolite in the ALCAPA MU. Thirty-five spots were measured, but only 18 proved to be concordant. These spots have $0.6 \pm 0.2$ (1 SD) average Th/U ratio and ages varying between 294 and 272 Ma except for the one with an outlier old core date of $876 \pm 11 \mathrm{Ma}$. Twelve spots give a 281.5 + 2.9 - 0.6 Ma TuffZirc Age (Fig. IV.6/f). IsoplotR resulted $281.0 \pm 0.5 \mathrm{Ma}(n=12)$ as concordia age for the outlier and discordant free datagroup (Electronic Supplementary Material IV.4). The interpreted eruption age of this sample is $281.0 \pm 2.9$ Ma taking in account the external errors (Table IV.2).

\subsection{Discussions and interpretations}

Permian felsic volcanic rocks in Hungary occur in two mega-units of different geological histories that are the Tisza MU and the ALCAPA MU. The Tisza MU is dominantly represented by felsic pyroclastic rocks, while lavas are subordinate and present only within the northern foreland of the Villány Mts (Szemerédi et al. 2016, 2017). Felsic 
volcanic rocks of the ALCAPA MU are represented by lavas and dykes that occur in the Central Transdanubian region and known from boreholes and outcrops. The presence of Permian volcanic rocks within the two terranes suggests two distinct volcanic events which are discussed below. In the following subsections the genetic interpretation of the felsic volcanic rocks, the geochemical character of these significantly altered rocks, the aspects of magma generation, their radiometric age data and the potential regional correlations are discussed.

\subsubsection{Genetic interpretations based on petrography and whole-rock geochemistry}

Felsic pyroclastic rocks in Southern Transdanubia (Western Mecsek Mts, MáriakéméndBáta BR, northern foreland of the Villány Mts) are rhyolitic in composition according to their mineralogical assemblage. The unsorted, massive appearance suggests pyroclastic flow (ignimbrite) origin. Ignimbrites with eutaxitic texture (Fig. IV.2/a, b) indicates hightemperature plastic deformation of the vitroclasts (both pumice and glass shards). Incipient to strong welding is indicated by the flattened pumices and sintering glass shards, that determines the foliation of the rocks (e.g., Gifkins et al. 2005b). Lapilli tuffs from the Battonya-Pusztaföldvár BR (eastern Pannonian Basin) are crystal-poor (10-25 vol\%) welded ignimbrites (Fig. IV.2/e) with rhyolitic composition lacking mafic components (e.g., altered pyroxene and biotite). Some of these rocks were affected by such a pervasive groundmass crystallization that their primary texture was completely overprinted, creating lava-like ignimbrites with felsitic texture (Szemerédi et al. in press). In pyroclastic samples of the Kelebia area quartz crystals having undulose extinction and deformation lamellae and phenocrysts with symmetric quartz and K-mica pressure shadow (Supplementary Figure IV.1/d) suggest that these rocks were affected by very low-grade metamorphism (e.g., Raucsik et al. 2016). The continuous, coherent bands of sericite are interpreted as a space foliation (Supplementary Figure IV.1/c) due to ductile shortening. According to the primary composition and textural features, these rocks are rhyodacitic ignimbrites.

Microholocrystalline or felsitic (Fig. IV.2/d), rarely relict perlitic, spherulitic or granophyric textures of felsic lavas from the northern foreland of the Villány Mts, represent a wide range of rhyolitic lava/dome lithofacies (microcrystalline core, perlitic core and brecciated variations of them as parts of the outer carapace; Szepesi et al. 2016; Szemerédi et al. 2017). Two sequences (boreholes Egerág-7 and Szalánta-3) with more 
plagioclase than potassium feldspar and no porphyric quartz suggest dacitic composition. Clots of zircon, apatite, opaque minerals, carbonate and muscovite (Supplementary Figure IV.1/e, f) suggest hydrothermal influence.

According to the mineralogical composition and the textural features, the rocks of the Kékkút-4 borehole are dacitic lavas. Subvolcanic dykes with similar mineralogical composition were found in the Devonian limestone quarry of Polgárdi (Fig. IV.2/g, h) most probably representing the same magmatic system.

Table IV.3 Petrographic classifications (based on the mineralogical, major element and immobile trace element compositions) of the studied Permian volcanic rock samples from the Tisza Mega-unit and the ALCAPA Mega-unit

\begin{tabular}{|c|c|c|c|c|c|c|}
\hline \multirow{2}{*}{$\begin{array}{l}\text { Subsurface } \\
\text { region or } \\
\text { outcrop }\end{array}$} & \multicolumn{5}{|c|}{ Tisza Mega-unit (Tisia Terrane) } & \multirow{2}{*}{$\begin{array}{l}\text { ALCAPA } \\
\text { Mega-unit } \\
\text { Central } \\
\text { Transdanubia }\end{array}$} \\
\hline & $\begin{array}{l}\text { Western } \\
\text { Mecsek Mts }\end{array}$ & $\begin{array}{l}\text { Máriakéménd } \\
\text {-Báta } \\
\text { Basement } \\
\text { Range }\end{array}$ & $\begin{array}{l}\text { Northern } \\
\text { foreland of the } \\
\text { Villány Mts }\end{array}$ & $\begin{array}{l}\text { Battonya- } \\
\text { Pusztaföldvár } \\
\text { Basement } \\
\text { Ridge }\end{array}$ & Kelebia area & \\
\hline Lithology & $\begin{array}{l}\text { Pyroclastic } \\
\text { rocks } \\
\text { (differently } \\
\text { welded } \\
\text { ignimbrites) }\end{array}$ & $\begin{array}{l}\text { Pyroclastic } \\
\text { rocks (welded } \\
\text { ignimbrites) }\end{array}$ & $\begin{array}{l}\text { Pyroclastic } \\
\text { rocks (Bisse-1, } \\
\text { Peterd-1, } \\
\text { Vókány-2, } \\
\text { Egerág-7, } \\
\text { Szalánta-3) and } \\
\text { lavas (Bisse-1, } \\
\text { Szava-1, } \\
\text { Egerág-7, } \\
\text { Szalánta-3) }\end{array}$ & $\begin{array}{l}\text { Pyroclastic } \\
\text { rocks (welded } \\
\text { ignimbrites) }\end{array}$ & $\begin{array}{l}\text { Pyroclastic } \\
\text { rock affected } \\
\text { by Alpine } \\
\text { low-grade } \\
\text { metamophism }\end{array}$ & $\begin{array}{l}\text { Lavas or } \\
\text { dykes }\end{array}$ \\
\hline $\begin{array}{l}\text { Mineralogical } \\
\text { classification }\end{array}$ & Rhyolite & Rhyolite & $\begin{array}{l}\text { Mostly } \\
\text { rhyolites, } \\
\text { rhyodacite- } \\
\text { dacite (lavas of } \\
\text { Egerág-7 and } \\
\text { Szalánta-3) }\end{array}$ & Rhyolite & Rhyodacite & Dacite \\
\hline $\begin{array}{l}\text { Geochemical } \\
\text { classification } \\
\text { (TAS) }\end{array}$ & Rhyolite & Rhyolite & Rhyolite & Ryholite & Trachydacite & Dacite \\
\hline $\begin{array}{l}\text { Geochemical } \\
\text { classification } \\
\left(\mathrm{Zr} / \mathrm{TiO}_{2} \text { vs. }\right. \\
\mathrm{Nb} / \mathrm{Y})\end{array}$ & $\begin{array}{l}\text { Rhyodacite } \\
\text {-dacite }\end{array}$ & $\begin{array}{l}\text { Rhyodacite- } \\
\text { dacite }\end{array}$ & $\begin{array}{l}\text { Rhyodacite- } \\
\text { dacite }\end{array}$ & $\begin{array}{l}\text { Rhyolite } \\
\text { (subordinate } \\
\text { rhyodacite- } \\
\text { dacite) }\end{array}$ & $\begin{array}{l}\text { Rhyodacite- } \\
\text { dacite }\end{array}$ & $\begin{array}{l}\text { Rhyodacite- } \\
\text { dacite }\end{array}$ \\
\hline
\end{tabular}

In case of some samples, their geochemical classification differ from the petrographic interpretation based on the major mineral assemblage, all results are compared in Table IV.3. Although in the TAS diagrams (Fig. IV.3), most of the samples plot in the rhyolite field, the immobile trace elements (in the $\mathrm{Zr} / \mathrm{TiO}_{2} \mathrm{vs} . \mathrm{Nb} / \mathrm{Y}$ diagram, Fig. IV.4) show dominantly rhyodacitic/dacitic composition. This might indicate significant post-magmatic changes in the major element compositions (e.g., $\mathrm{SiO}_{2}$ gain, $\mathrm{Na} / \mathrm{K}$-metasomatism) except for the Kékkút-4 sample of the ALCAPA MU which proves to be relatively less altered. Thus, immobile element-based rock classifications $\left(\mathrm{Zr} / \mathrm{TiO}{ }_{2}\right.$ vs. $\mathrm{Nb} / \mathrm{Y}$ ) were accepted, suggesting rhyodacitic/dacitic composition for the majority of 
the samples, which is in agreement with their major mineral assemblage and with the crystal-rich character (in case of dacites) of the rocks. The latter ones comprise mostly ignimbrites with variable degrees of welding and possibly, these rocks of Southern Transdanubia and the Kelebia area could represent the so-called crystal-rich monotoneous intermediates (e.g., Hildreth 1981). The crystal-poor and quartz dominated samples of the Battonya-Pusztaföldvár BR show rhyolitic immobile trace element character; thus, they are interpreted to be rhyolites and could represent the crystal-poor, melt-dominated silicic volcanic rocks (e.g., Hildreth 1981; Huber et al 2012). Felsic effusive rocks from the Kékkút-4 borehole (ALCAPA MU) are less altered and show dacitic composition both in major and trace element-based classification diagrams (Table IV.3).

\subsubsection{Post-magmatic alterations}

The major element geochemistry is clearly showing the alteration effects which is characteristic for other Permian volcanic series (Paulick and Breitkreuz 2005, Nicolae et al. 2014, Vozárová et al. 2009, 2015, 2016). Effects of K-metasomatism are indicated by the high potassium/total alkali ratio, $\mathrm{K}_{2} \mathrm{O}(\mathrm{wt} \%) /\left[\mathrm{Na}_{2} \mathrm{O}(\mathrm{wt} \%)+\mathrm{K}_{2} \mathrm{O}(\mathrm{wt} \%)\right] \times 100$, that is higher than 90 in case of six samples and most of the samples lie outside the igneous spectrum (Hughes 1973). The $\mathrm{Na}_{2} \mathrm{O} / \mathrm{Al}_{2} \mathrm{O}_{3}$ vs. $\mathrm{K}_{2} \mathrm{O} / \mathrm{Al}_{2} \mathrm{O}_{3}, \mathrm{Na}_{2} \mathrm{O} / \mathrm{K}_{2} \mathrm{O}$ vs. $\mathrm{SiO}_{2} / \mathrm{Al}_{2} \mathrm{O}_{3}$ (Garrels and Mackenzie 1971; Fig. IV.7/a, b) and $\mathrm{Na}_{2} \mathrm{O}$ vs. $\mathrm{K}_{2} \mathrm{O}$ diagrams (Paulick and Breitkeruz 2005; Fig. IV.7/c) clearly show the alteration effects on the whole-rock geochemistry. Both K-metasomatism (adularization) and albitization were suggested in the previous reports of uranium ore exploration (Fazekas 1978; Barabásné Stuhl 1988; based on petrographic and geochemical observations). This was confirmed by recent studies based on the petrography of samples of Southern Transdanubia and by XRD analyses of separated feldspar crystals that showed the existence of adularia (Szemerédi et al. 2016, 2017). K-metasomatism or albitization are general features of the other Permian felsic volcanic rocks in the European Variscides (Awdankiewicz 1999; Paulick and Breitkreuz 2005; Vozárová et al. 2015, 2016; Szemerédi et al. 2016, 2017).

The Máriakéménd-3 and Vókány-2 samples are outliers with their extremely low immobile trace element compositions (including REE, U, Th, Y and Zr, Fig. IV.5), suggesting the mobilization of these elements. The mobility could be associated with hydrothermal fluids, that might have leached these elements from accessory minerals, particularly from fractured and/or metamict zircon or apatite, monazite and xenotime 


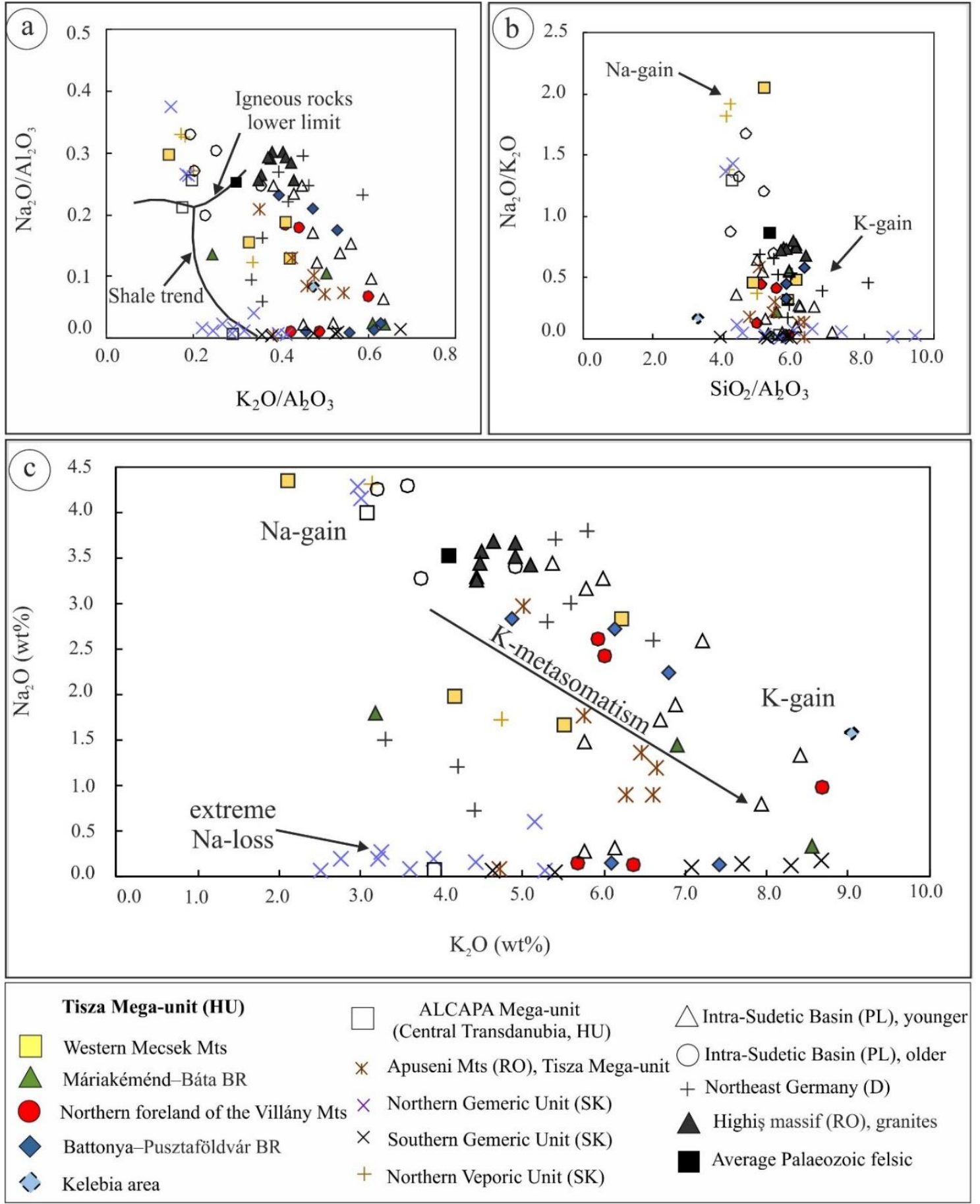

Figure IV.7 $\mathrm{Na}_{2} \mathrm{O} / \mathrm{Al}_{2} \mathrm{O}_{3}$ vs. $\mathrm{K}_{2} \mathrm{O} / \mathrm{Al}_{2} \mathrm{O}_{3}(\mathbf{a}), \mathrm{Na}_{2} \mathrm{O} / \mathrm{K}_{2} \mathrm{O}$ vs. $\mathrm{SiO}_{2} / \mathrm{Al}_{2} \mathrm{O}_{3}$ (b; Garrels and Mackenzie 1971) and $\mathrm{Na}_{2} \mathrm{O}$ vs. $\mathrm{K}_{2} \mathrm{O}$ diagrams (c; Paulick and Breitkreuz 2005) focusing on the post-magmatic alterations of Permian volcanic rocks of the Tisza Mega-unit, the ALCAPA Mega-unit, Hungary and the analogous formations from the European Variscides. The references of the comparative data are the same as those in Fig. IV.3

(e.g., Rubin et al. 1993; Jiang et al. 2004; René 2014). Petrographic observations revealed the scarcity in zircon and other accessory minerals, a possible sign of hydrothermal alteration. Mobility of REE, U, Th, Y and Zr is most common, but not restricted to F-rich hydrothermal solutions related to alkali igneous suites (Rubin et al. 1993). Formation of uranium ore deposits is often associated with the mobility of these immobile elements 
(René 2014). Uranium mineralization is known in the Western Mecsek Mts, close to the outcrop of the Gyürüfü Rhyolite (Dinnyeberki uranium ore deposit, Vincze et al. 2011; Konrád et al. 2012). On the other hand, hydrothermal sulfidic mineralization (related to dykes filled with quartz, pyrite, siderite, hydromuscovite, hematite, chalcopyrite etc.; Fazekas and Vincze 1991) is also known from levels of the Szava-1 borehole in the northern foreland of the Villány Mts and presumably formed due to the interaction of the felsic volcanic (host) rock with hydrothermal fluids. These local ore formations could be the feasible sites of accumulation of the immobile elements leached from Permian volcanic rocks represented by the Máriakéménd-3 and Vókány-2 drill cores.

Partially similar depletion trends characterize the Polgárdi sample that shows depletion in heavy REEs and in many other immobile elements (including $\mathrm{Hf}, \mathrm{Zr}$ and Y) and remarkedly higher depletion in $\mathrm{Ba}, \mathrm{Sr}$ and $\mathrm{Ti}$ compared to the less altered Kékkút core from the ALCAPA MU. Lower values of these immobile elements in the rocks might be due to weathering processes of accessory minerals that have been accumulated them before (e.g., garnet and monazite). On the other hand, it is also possible that the volcanic rocks of the Kékkút-4 borehole ( $291 \mathrm{Ma}$; Lelkes-Felvári and Klötzli 2004) and the younger ( $281 \mathrm{Ma})$ dacitic dykes in the Polgárdi quarry represent two distinct volcanic episodes of a long-lasting magmatism; thus, they bear slighter geochemical differences. The three altered samples (Máriakéménd-3, Vókány-2, Polgárdi) are not used for magmatic interpretations.

\subsubsection{Tectonic implications and the potential source of the magmatism}

Silicic volcanic rocks could occur in various tectonic settings. Pearce et al. (1984) suggested a set of diagrams to discriminate them, where the Y-Nb plot (Fig. IV.8/a) seems to be the less affected by secondary alteration. Rhyodacitic/dacitic rocks of the Western Mecsek Mts, the Máriakéménd-Báta BR and the northern foreland of the Villány Mts fall into the border between the volcanic-arc and the within-plate-granite fields, while the rhyodacitic/dacitic samples of the Kelebia area and rhyolitic rocks of the BattonyaPusztaföldvár BR all plot in the within plate-granite field. On the other hand, the dacitic sample of the ALCAPA MU (Kékkút-4) falls into the volcanic-arc granite field. Similar discrimination diagram was introduced by Gorton and Schandl (2000) using Ta, Th and $\mathrm{Yb}$ in which the samples generally plot in the active continental margins field (Fig. IV.8/b). REE patterns are also useful tools for tectonic implications in case of silicic 

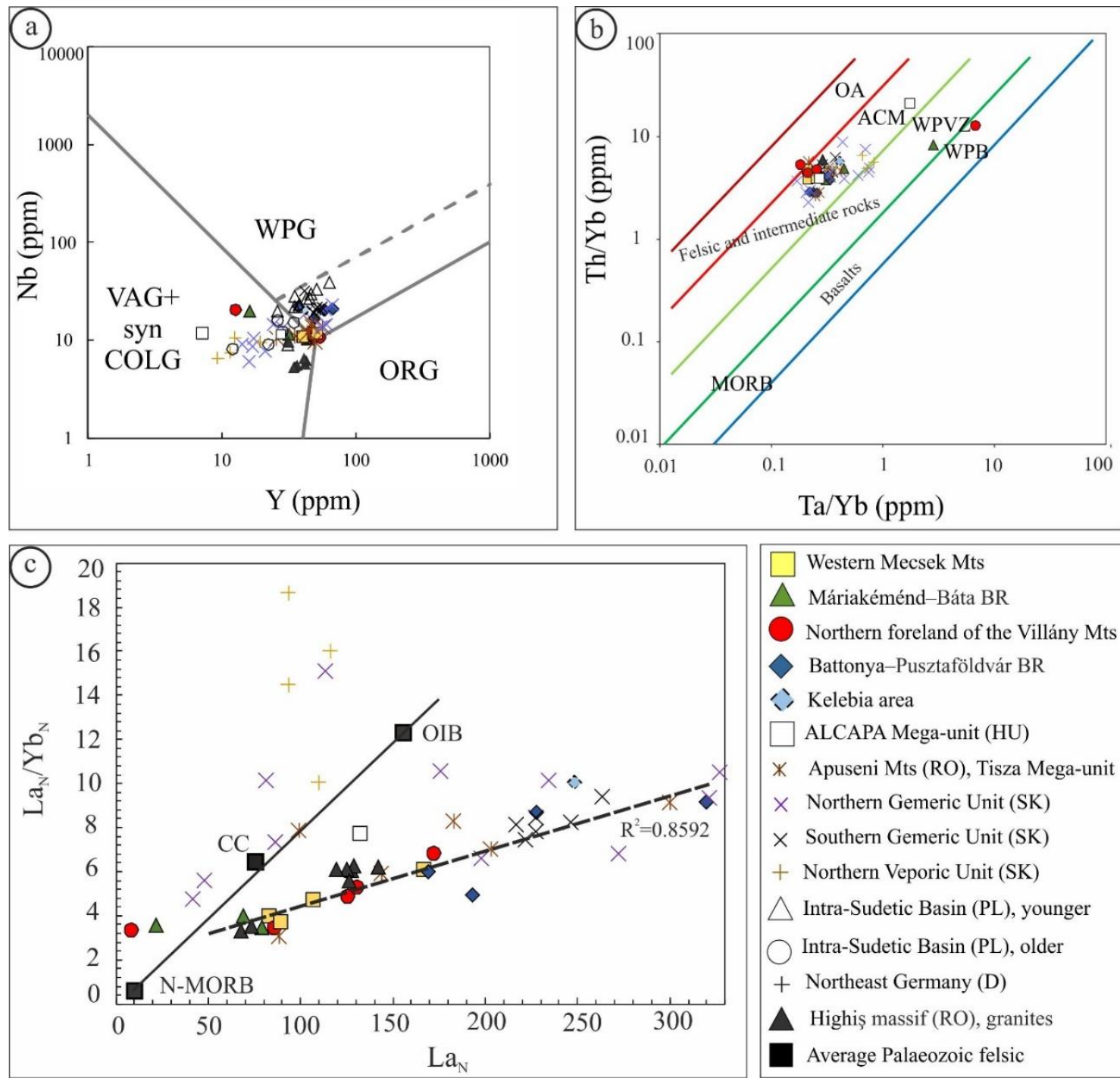

\begin{tabular}{|l}
$\square$ Western Mecsek Mts \\
$\triangle$ Máriakéménd-Báta BR \\
Northern foreland of the Villány Mts \\
Battonya-Pusztaföldvár BR \\
- Kelebia area \\
$\square$ ALCAPA Mega-unit (HU) \\
$\times \quad$ Apuseni Mts (RO), Tisza Mega-unit \\
$\times \quad$ Northern Gemeric Unit (SK) \\
+ Southern Gemeric Unit (SK) \\
$\triangle$ Intra-Sudetic Basin (PL), younger \\
Intra-Sudetic Basin (PL), older \\
+ Northeast Germany (D) \\
$\triangle$ Highiş massif (RO), granites \\
$\square$ Average Palaeozoic felsic
\end{tabular}

Figure IV.8 Nb-Y (a; Pearce et al. 1984) and Th/Yb vs. Ta/Yb (b; Gorton and Schandl 2000) discrimination diagrams and $\mathrm{La}_{\mathrm{N}}$ vs. $\mathrm{La}_{\mathrm{N}} / \mathrm{Yb}_{\mathrm{N}}$ diagram (c) for the Permian volcanic rocks of the Tisza Mega-unit, the ALCAPA Mega-unit, Hungary and the analogous formations of the European Variscides. $O R G$ ocean ridge granites, syn-COLG syn-collision granites, $V A G$ volcanic arc granites, $W P G$ withinplate granites, $O A$ oceanic arcs, $A C M$ active continental margins, $W P V Z$ within-plate volcanic zones, $W P B$ within-plate basalts, $M O R B$ mid-ocean ridge basalts, $N$-MORB Mid Ocean Ridge Basalt (Sun and McDonough 1989), OIB Ocean Island Basalt (Sun and McDonough 1989), $C C$ average continental crust (Rudnick and Fountain 1995). The references of the comparative data are the same as those in Fig. IV.3

volcanic and plutonic rocks (Christiansen 2005; Bachmann and Bergantz 2008; Christiansen and McCurry 2008). Hot-dry-reduced magmas with their characteristic 'seagull' pattern (deep negative Eu anomaly) are formed in the areas of mantle upwelling (hotspots and continental rifts), while cold-wet-oxidized magmas (with insignificant negative Eu anomaly) are found in subduction zones (Christiansen 2005; Bachmann and Bergantz 2008; Christiansen and McCurry 2008). All samples of the Tisza MU show 'seagull' pattern suggesting hot-dry-reduced magmas, while REE patterns of the ALCAPA MU refer to cold-wet-oxidized magmas. REE patterns also correspond to the mafic mineral assemblages: pseudomorphs after anhydrous pyroxene occur in most of the 
samples of the Tisza MU, while hydrous amphiboles (pseudomorphs) were observed only in the samples of the Kékkút-4 borehole (ALCAPA MU). This bimodal magmatectonic character can be explained by a post-collisional tectonic regime as described from various parts of the European Variscides (Awdankiewicz 1999; Wilson et al. 2004; Nicolae et al. 2014; Vozárová et al. 2015; Repstock et al. 2017, etc.).

Trace element and REE patterns of the samples of the Tisza MU show significant similarity with the felsic volcanic rocks of the Apuseni Mts, Romania (Nicolae et al. 2014; Fig. IV.5) implying a possible common origin. However, in the $\mathrm{La}_{N} / \mathrm{Yb}_{\mathrm{N}} \mathrm{vs}$. La $\mathrm{a}_{\mathrm{N}}$ diagram (Fig. IV.8/c), they show slightly different trends. Felsic rocks from the Tisza MU follow a linear positive trend that could be explained by fractional crystallization involving possibly garnet and/or zircon. Some pyroclastic rocks of the Villány Mts (Egerág-7 and Szalánta-3 boreholes) contain garnet crystals. Garnets are rare primary mineral phase in intermediate and silicic igneous rocks and are formed either in the early stage of magma evolution from hydrous magma at high pressure (Harangi et al. 2001), or in certain cases, they could be also late stage crystallization products. Although mafic-intermediate rocks are not known in the territory of Hungary, contrary to the Apuseni Mts, where basaltic and subordinate andesitic lavas are present (Nicolae et al. 2014), the Permian volcanic activity resulting in felsic rocks could have occurred close to each other. Nicolae et al. (2014) used $\mathrm{Sr}-\mathrm{Nd}$ isotope geochemistry and supposed the magma generation within the lower crust due to emplacement of mantle-derived magmas that provided heat to partial melting. Although pure anatexis of crustal material to yield large volume of silicic magma is thermally not favourable, in the magma evolution, we cannot exclude significant contribution from the crust as an assimilation combined with fractional crystallization (AFC) process.

Further geochemical similarity between the samples of the Tisza MU and the Permian rhyolitic ignimbrites of the Southern Gemeric Unit (SGU; Western Carpathians, ALCAPA MU; Vozárová et al. 2009), was also observed based on the immobile trace element composition. In the $\mathrm{Zr} / \mathrm{TiO}_{2}$ vs. $\mathrm{Nb} / \mathrm{Y}$ diagram (Fig. IV.4), samples of the SGU plot close to the rhyolites of the Battonya-Pusztaföldvár BR and their chondritenormalized REE and trace element distributions (SGU: not shown in this study, see details in Vozárová et al. 2009) show very similar pattern. Furthermore, there are also Permian granites in the Highiş massif (Apuseni Mts; Pană et al. 2002; Pál-Molnár et al. 2008) that have similar geochemical character. Although the close plutonic-volcanic connection demands further detailed investigation, it is plausible to assume some relationships. 
In the $\mathrm{La}_{N} / \mathrm{Yb}_{\mathrm{N}}$ vs. LaN diagram (Fig. IV.8/c), samples of the SGU plot strinkingly close to the trendline of the Permian felsic volcanic rocks of the Tisza MU. Closer genetic relationship cannot be excluded since the SGU (and other crustal-scale superunits of Westerns Carpathians, e.g., Northern and Southern Veporic Unit, Northern Gemeric Unit etc.) could have situated on the southern margin of the European plate during the Permian as well as the Tisza MU (Haas et al. 1999). Notably, Permian volcanic rocks of Central Transdanubia show similar REE and trace element patterns with the samples of the Northern Veporic Unit (Western Carpathians; Vozárová et al. 2016; Fig. IV.5) suggesting their relationship both being parts of the ALCAPA MU.

\subsubsection{Geochronology and correlation}

Based on the results of the zircon $\mathrm{U}-\mathrm{Pb}$ geochronology, the volcanic rocks of the Battonya-Pusztaföldvár BR give slightly younger formation age $(\sim 260 \mathrm{Ma})$ than those found in Southern Transdanubia and the Kelebia area (267-264 Ma) of the Tisza MU. The ALCAPA sample (Polgárdi) gives the oldest age ( $281 \mathrm{Ma})$ and it is closer to the 291 Ma ID-TIMS age of the Kékkút-4 sample (Lelkes-Felvári and Klötzli 2004). The apparent age difference between Kékkút- 4 and Polgárdi samples may be explained by older cores in the bulk zircon age determination supported by the fact that two older single crystal ages were ruled out of the six analyses by Lelkes-Felvári and Klötzli (2004) in the interpretation of the $\mathrm{U}-\mathrm{Pb}$ ages in the Kékkút-4 sample, suggesting the presence of inherited cores in the zircon crystals. The presence of old cores could indicate crustal components in their petrogenesis.

There is a striking similarity in the ages with the Permian rhyolites from the Silicic Unit (Western Carpathians; Ondrejka et al. 2018; Fig. IV.9). Permian volcanic rocks of the Northern Veporic Unit and the Gemeric Unit (Fig. IV.9, IV.10/b) have slightly older zircon ages that are more closer the age of the Polgárdi sample $(\sim 281 \mathrm{Ma})$ of the ALCAPA MU, supporting the geochemical correlation between the Permian felsic volcanic rocks of the Northern Veporic Unit and Central Transdanubia (Fig. IV.5). Lelkes-Felvári and Klötzli (2004) suggested a possible genetic link between the Kékkút4 sample and the Bozen/Bolzano Quartz Porphyry from the Southern Alps located in the same mega-unit (e.g., Morelli et al. 2007).

In the Western Carpathians a dominant Kungurian magmatic event ( 280-270 Ma; Fig. IV.9) was documented and linked to post-orogenic transpression/transtension 


\begin{tabular}{|c|c|c|c|c|c|c|c|c|c|c|}
\hline \multirow{4}{*}{ 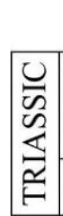 } & \multirow{3}{*}{ 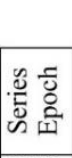 } & \multirow{3}{*}{$\begin{array}{c}\text { Stage } \\
\text { Age }\end{array}$} & \multirow[b]{3}{*}{$\begin{array}{l}\text { Age } \\
\text { Ma }\end{array}$} & \multicolumn{3}{|c|}{ Tisza Mega-unit } & \multicolumn{4}{|c|}{ ALCAPA Mega-unit } \\
\hline & & & & \multirow{2}{*}{\begin{tabular}{|c|} 
Southern \\
Transdanubia \\
(HU)
\end{tabular}} & \multirow{2}{*}{$\begin{array}{c}\text { Great } \\
\text { Hungarian } \\
\text { Plain (HU) }\end{array}$} & \multirow{2}{*}{$\begin{array}{l}\text { Apuseni Mts } \\
\text { (RO) }\end{array}$} & \multirow{2}{*}{\begin{tabular}{|c|} 
Central \\
Transdanubia \\
(HU)
\end{tabular}} & \multicolumn{3}{|c|}{ Western Carpathians } \\
\hline & & & & & & & & $\begin{array}{l}\text { Gemeric } \\
\text { Unit (SK) }\end{array}$ & $\begin{array}{l}\mathrm{N} \text { Veporic } \\
\text { Unit (SK) }\end{array}$ & $\begin{array}{c}\text { Silicic } \\
\text { Unit (SK) }\end{array}$ \\
\hline & $\begin{array}{c}\text { EAR. } \\
\text { p.p. }\end{array}$ & $\begin{array}{c}\text { OLENEKIAN } \\
\text { INDUAN }\end{array}$ & & & & & & ( & & \\
\hline Z & ठิ & $\begin{array}{l}\text { CHANGHSINGIAN } \\
\text { WUCHIAPINGIAN }\end{array}$ & & $265.3 \pm 2.7$ & $\frac{259.5 \pm 2.6}{259.5 \pm 2.6}$ & & & $\mid$\begin{tabular}{|c}
$251.4 \pm 3.5$ \\
(Vozárová et al
\end{tabular} & & \\
\hline & 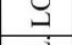 & & & $\begin{array}{l}205.3 \pm 2.1 \\
\text { Northern foreland }\end{array}$ & T. $\frac{259.5 \pm 2.0}{\text { Battonya- }}$ & $\begin{array}{l}264.2 \pm 2.3 \\
\text { Pană et al. 2002) }\end{array}$ & & $2015, \mathrm{NGU})$ & & \\
\hline$\ll$ & 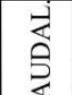 & $\begin{array}{c}\text { CAPITANIAN } \\
\text { WORDIAN } \\
\end{array}$ & & $\begin{array}{l}\text { of the Villány Mts } \\
\text { T. } 266.8 \pm 2.7 \\
\text { Western Mecces }\end{array}$ & $\begin{array}{l}\text { T- Pusztaföldvár } \\
\text { BR } \\
1 \mathbf{2 6 3 . 4 \pm 2 . 7} \\
\text { Kelebia area }\end{array}$ & $I_{266.7 \pm 3.8}$ & & {$\left[\begin{array}{c}268.9 \pm 6.9 \\
(\text { Vozárová et al al } \\
2015, \mathrm{NGU})\end{array}\right]$} & $0 \pm 4.0$ & 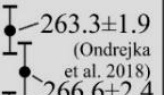 \\
\hline - & త & ROADIAN & $270=$ & & & (Pană et al. 2002) & & $273.3 \pm 2.8$ & (Vozárová et & T $266.6 \pm 2.4$ \\
\hline$\Sigma$ & 乙 & KUNGURIAN & 275 & & & & $\begin{array}{r}279 \pm 3 \\
\text { (Kelemen et al. } \\
2017)\end{array}$ & - & {$\left[\begin{array}{r}\text { al. 2016) } \\
272.9 \pm 5.9 \\
\text { (Vozárová et }\end{array}\right.$} & $\begin{array}{c}\text { et al. 2018) } \\
269.5 \pm 1.8 \\
\text { (Ondrejke et al. } 2018\end{array}$ \\
\hline$\simeq$ & ঊ & ARTINSKIAN & $280 \frac{\exists}{3}$ & & & & {$\left[\frac{281.0 \pm 2.9}{\text { Polgárdi }}\right.$} & $\begin{array}{c}275.3 \pm 2.9 \\
\text { (Vozárová et al } \\
2009, \text { SGU) }\end{array}$ & {$\left[\begin{array}{c}\text { al. 2016) } \\
279.0 \pm 4.4\end{array}\right.$} & \\
\hline 四 & $\begin{array}{l}a 1 \\
b \\
\text { n } \\
=1\end{array}$ & SAKMARIAN & 290 & & & & $\mid \begin{array}{c}291.4 \pm 4.7 \\
\text { (Lelkes-Felvari \& } \\
\text { Klötzli 2004) }\end{array}$ & & $\begin{array}{l}\text { (vozarova } \\
\text { et al. 2016) }\end{array}$ & \\
\hline & 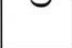 & ASSELIAN & & & & & & & & \\
\hline CAR & B. PENN & GZELIAN & $300=$ & & & & & & & \\
\hline
\end{tabular}

Figure IV.9 Radiometric age data of Permian felsic volcanic rocks of the European Variscides, summarizing all magmatic events that are significant for the correlation of the Permian felsic volcanic rocks in Hungary (Pană et al. 2002; Lelkes-Felvári and Klötzli 2004; Vozárová et al. 2009, 2015, 2016; Kelemen et al. 2017; Ondrejka et al. 2018). The U-Pb zircon age of this study are bold and underlined. Carb. Carboniferous, Ear. Early Triassic, Guadal. Guadalupian, Loping. Lopingian, Penn.

Pennsylvanian, $H U$ Hungary, $R O$ Romania, $S K$ Slovakia

tectonic movements (Vozárová et al. 2009, 2015, 2016). However, significantly younger volcanic episodes (up to the Permian-Triassic boundary, $251 \mathrm{Ma}$ ) are also known in the area that were linked to an extensional tectonic setting (continental rift; Vozárová et al. 2015; Ondrejka et al. 2018). As it was mentioned before, most of the observed samples fall into the border between the volcanic-arc and the within-plate-granite fields (Fig. IV.8/a); however, the youngest volcanic rocks (Battonya-Pusztaföldvár BR and Kelebia area; Fig. IV.9) plot clearly in the within-plate-granite field. Thereby, these rocks could be connected to the beginning of the Alpine orogenic cycle, the extensional setting succeeding the post-collisional environment in which the volcanic rocks of Transdanubia (samples of the ALCAPA MU and Southern Transdanubia) could be formed.

Pană et al. (2002) published two U-Pb ID-TIMS zircon ages (266.7 $\pm 3.8 \mathrm{Ma}$ and $264.2 \pm 2.3 \mathrm{Ma}$ ), which actually cannot be distinguished, for two different rock types from the anorogenic Highiş massif (Apuseni Mountains, Romania; Fig. IV.10). These ages agree with the age data of the Permian volcanic rocks of the Tisza MU corroborating the geochemical observations and the assumption about their genetic link. Regarding a broader correlation, the radiometric ages of the studied Permian volcanic rocks of the Tisza MU are significantly younger than the zircon ages of other well studied parts of the Central European Variscides (e.g., Intra-Sudetic Basin, NE Germany), where much older 
ages were detected ( 300-280 Ma; Breitkreuz and Kennedy 1999; Wilson et al. 2004; Awdankiewicz and Kryza 2010; Repstock et al. 2017; Słodczyk et al. 2018).

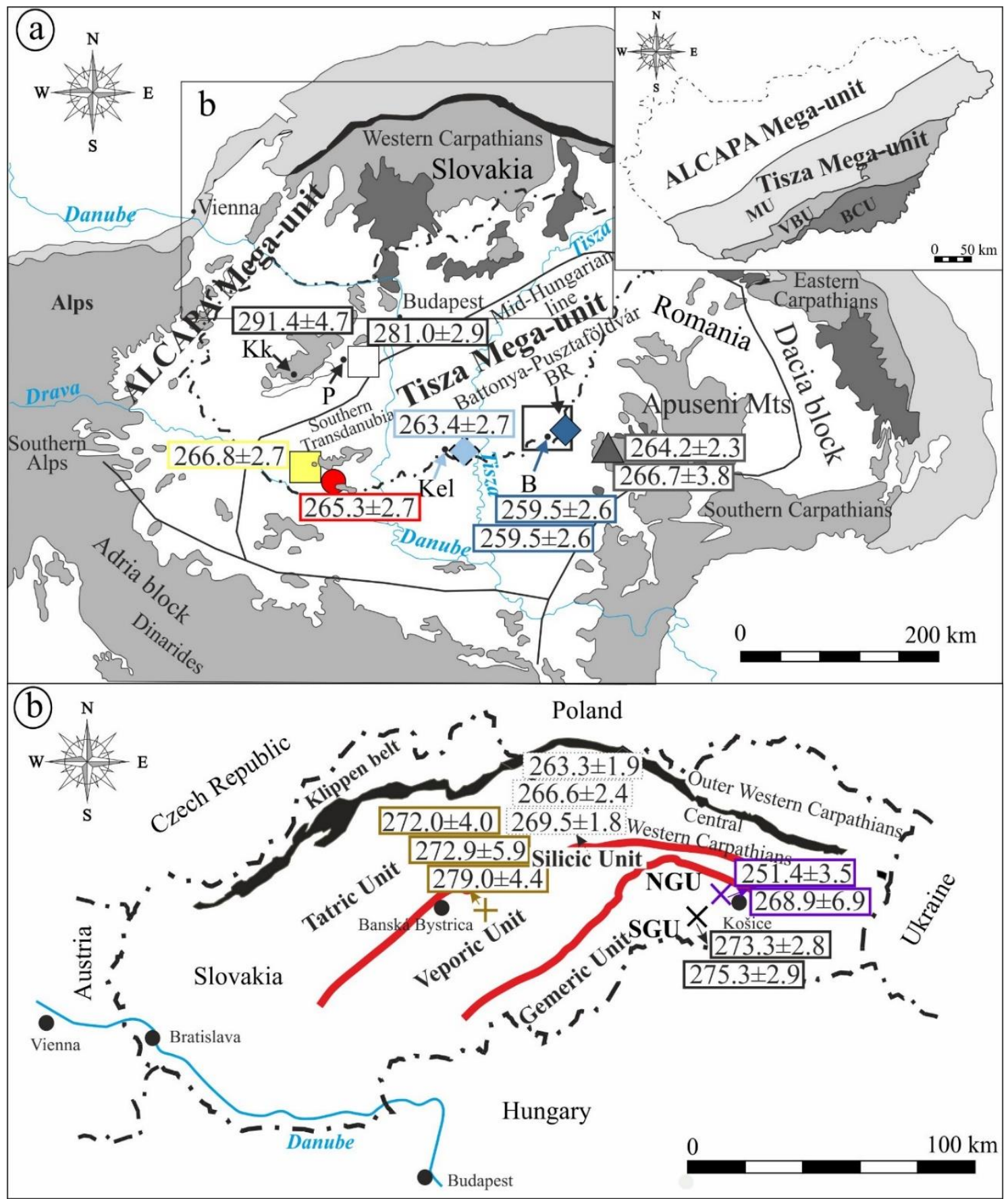

Figure IV.10 Permian felsic magmatic events in the Carpathian-Pannonian region (a) displayed by weighted mean ages (Ma), highlighting crustal-scale superunits of the Western Carpathians and representative ages (b, modified after Kohút et al. 2013). Index map shows the Alpine facies zones of the study area (modified after Szederkény et al. 2013). $M U$ Mecsek Unit; $V B U$ Villány-Bihor Unit; $B C U$ Békés-Codru Unit; $N G U$ Northern Gemeric Unit; $S G U$ Southern Gemeric Unit. Results derive from Pană et al. (2002), Lelkes-Felvári and Klötzli (2004), Vozárová et al. (2009, 2015, 2016), Ondrejka et al. (2018) 


\subsection{Conclusions}

Permo-Carboniferous volcanism controlled by a post-collisional to extensional tectonic setting is a common feature in the European Variscan Orogenic Belt. In the territory of Hungary, two distinct Permian volcanic activities were revealed by $\mathrm{U}-\mathrm{Pb}$ zircon geochronology: an older one ( $281 \mathrm{Ma}$, Cisuralian) resulting in dacitic lava flows/domes and dykes in the ALCAPA MU, and a younger volcanic activity ( 267-260 Ma, Gaudalupian) producing rhyodacitic/dacitic to rhyolitic pyroclastic and subordinate lavas in the Tisza MU. Most of these Permian volcanic rocks are affected by various postmagmatic processes (K-metasomatism, albitization, Alpine low-grade metamorphism, hydrothermal alteration), which variably modified their major element composition. However, in most cases the immobile, incompatible trace elements provide valuable information about the rock types and the petrogenetic processes.

Permian volcanic rocks are less abundant in Central Transdanubia (ALCAPA MU), where dacitic lavas are known by boreholes and as dykes in the limestone quarry near Polgárdi. These rocks are less affected by post-magamatic alterations preserving their original major element composition. Based on trace element geochemistry and zircon geochonology, the dacitic lavas of Central Transdanubia correlate with the volcanic rocks from the Northern Veporic Unit (Slovakia) that is located also in the ALCAPA MU.

In the Tisza MU, crystal-rich rhyodacitic/dacitic ignimbrites are the dominant lithologies (Southern Transdanubia and the Kelebia area), while crystal-poor rhyolitic ignimbrites (Battonya-Pusztaföldvár BR) are less common. In this tectonic unit, lavas are subordianate, rhyodacitic/dacitic lavas occur in the northern foreland of the Villány Mts (Southern Transdanubia). Permian felsic volcanic rocks within the Tisza MU could represent the same volcanic activity and can be correlated with the felsic rocks found in the Apuseni Mts (Romania). Moreover, these volcanic rocks show potential relationship with Permian granitic rocks of the Highiş massif, Apuseni Mts (according to their geochemical character and zircon $\mathrm{U}-\mathrm{Pb}$ ages). Based on the new geochronological results Permian volcanic rocks not only in Central Transdanubia, but also in the Tisza MU show similtarity with such rocks of the Western Carpathians (ALCAPA MU). 


\section{CHAPTER V}

\section{Conclusions}

\subsection{Summary of the results}

In this doctoral research, Permian felsic volcanic rocks of the Gyürüfü Rhyolite Formation were studied, including almost all the available drill cores and outcrops. The applied methods included petrographic observations, whole-rock geochemical analyses (major and trace elements) and zircon $\mathrm{U}-\mathrm{Pb}$ radiometric age determinations. In the followings, all the new results are summarized by the two main occurrences (Southern Transdanubia and the eastern Pannonian Basin) of the Permian felsic volcanic rocks in the Tisza Mega-unit (Hungary), then integrated at a larger scale.

\subsubsection{Southern Transdanubia}

In the area of Southern Transdanubia, the Gyürüfü Rhyolite Formation crops out only in the Western Mecsek Mts (Gyürüfü area); however, it was penetrated by several boreholes of uranium ore exploration in the 60's. Based on the drilling results, three main subsurface areas are separated that are the Western Mecsek Mts, the northern foreland of the Villány Mts and the Máriakéménd-Báta Basement Range.

Felsic volcanic rocks of the single outcrop proved to be pyroclastites (lapilli tuffs). Based on the microscopic characteristics, two distinct lithofacies were separated among the outcrop rock samples: (1) eutaxitic, welded crystal-rich, pumice-bearing lapilli tuffs and (2) non-welded crystal-rich, pumice-bearing lapilli tuffs. The former, well-visibly oriented samples could represent the proximal, while the latter might be derived from the upper, the lowermost, the sideward or the distal part of a valley-filling pyroclastic flow. Despite the previous interpretations (Szederkényi 1962; Fazekas 1978; Barabásné Stuhl 1988; Barabás and Barabásné Stuhl 1998), effusive rocks were not found in the Western Mecsek Mts. Volcanites of the Máriákéménd-Báta Basement Range completely resemble to those of the Western Mecsek Mts, and were interpreted as crystal-rich, pumice-bearing lapilli tuffs, as well. In these samples, various intensity of welding was observed, too. At the northern foreland of the Villány Mts, one group of the studied drill cores showed similar features, e.g., the samples of the Peterd-1 well and the upper volcanic sequences of the Bisse-1, the Vókány-2, the Szalánta-3 and the Egerág-7 boreholes, also referring to pyroclastic origin. On the other hand, in the Szava-1 well and at some borehole levels 
(lower sequences) of the abovementioned drillings (excepting Peterd-1 borehole), subvolcanic rocks/lavas occur. On the whole, the pyroclastic rocks are much more abundant in this area than they were previously reported (Fazekas 1978; Barabásné Stuhl 1988), and both effusive and explosive eruptions played an important role in the Permian felsic volcanism.

According to the mineralogy and the major element geochemistry (TAS diagram), the observed samples in S Transdanubia are dominantly rhyolites; however, immoblile trace elements $\left(\mathrm{Zr} / \mathrm{TiO}_{2}\right.$ vs. $\mathrm{Nb} / \mathrm{Y}$ diagram $)$ showed that they have primary rhyodacitic/dacitic composition. Changes in the major element geochemistry refer to post-magmatic alterations, such as K-metasomatism supported by the adularization of some samples (e.g., Gyürüfü outcrop and Peterd-1 core samples) and the whole-rock geochemistry of the rocks (Fazekas 1978; Barabásné Stuhl 1988). Immobile trace elements (e.g., REE patterns and multi-element spider diagrams) suggest that all the Permian felsic volcanic rocks in S Transdanubia could be derived from the same source. In case of two samples (Vókány-2 and Máriakéménd-3 boreholes), it is feasible that even the immobile elements were mobilized by hydrothermal fluids.

Zircon $\mathrm{U}-\mathrm{Pb}$ ages were obtained from the drill core of the Szava-1 borehole (subvolcanic rock/lava) and the pyroclastic rocks cropping out in the Gyürüfü area. The subvolcancic/lava sample has showed $265.3 \pm 2.7 \mathrm{Ma}$, while the felsic pyroclastic rocks have $266.8 \pm 2.7 \mathrm{Ma}$ interpreted eruption ages. Actually, these two ages are identical at the level of uncertainty and as a first order interpretation they are grouped in the same volcanic episode.

According to the lithologies of the drillings in S Transdanubia, an earlier effusive magmatism is feasible that was followed in a short interval by explosive eruptions, forming a thick ignimbrite sheet (possibly up to several hundred metres). However, it cannot be excluded that effusive and explosive volcanism occurred simulaneously in the area.

\subsubsection{Eastern Pannonian Basin (SE Hungary)}

In the eastern Pannonian Basin (SE Hungary, Békés-Codru Unit), Permian felsic volcanic rocks were encountered in petroleum exploration boreholes. Their occurrences in the basement of the Tisza Mega-unit include the areas of Battonya, Biharugra, Kelebia, Mezőkovácsháza, Nagyszénás, Pitvaros, Pusztaföldvár, Tótkomlós and Végegyháza 
(Császár 2005). These rocks were also classified into the Gyürüfü Rhyolite Formation such as all the Permian felsic volcanic rocks in the Tisza Mega-unit; despite the large distance from the Gyürüfü area, Western Mecsek Mts, S Transdanubia. Previous reports of hydrocarbon exploration work basically interpreted them as lavas (the so-called "Battonya quartz-porphyry"; Szepesházy 1967; Körössy 2005a,b). During the doctoral research, drill cores were available and studied from the Battonya, the Biharugra, the Kelebia and the Tótkomlós areas.

The Battonya area was the most thoroughly explored by boreholes; drill cores of fourteen of them were studied during the $\mathrm{PhD}$ research. The samples are generally crystalpoor (8-20 vol\%) rhyolitic pyroclastic rocks (ignimbrites). In the $\sim 60 \mathrm{~km}^{2}$ area, textural investigations established the discrimination of two distinct lithofacies: (1) eutaxitic, massive, matrix-supported, porphyric, fiamme-bearing lapilli tuffs and (2) felsitic, matrix-supported, porphyric, fiamme-bearing lapilli tuffs. The former proved to be welded ignimbrite, while the latter is most possibly high-grade rheomorphic ignimbrite. Several evidence supported that a part of an ignimbrite sheet was penetrated by the boreholes near Battonya; however, the drillings most possibly ended in its uppermost part of an average $20 \mathrm{~m}$. In contrast to other boreholes in the Battonya area, the Battonya-7 well explored a pyroclastic rock with armored pellets, suggesting its formation in a pyroclastic ash cloud (co-ignimbrite ash or eruption cloud) possibly under wet conditions.

Reworking of such pyroclastic rocks could result in the samples of the Biharugra and the Tótkomlós areas that were classified as lithic-rich, massive, strongly sericitized, poorly-sorted volcaniclastics. These resedimented pyroclastic (Tótkomlós) and volcanogenic sedimentary rocks (Biharugra) consist of various felsic volcanic lithics and might suggest a multiple-phase Permian volcanic activity that was also documented in the nearby Apuseni Mts, Romania (Codru Nappe System; Nicolae et al. 2014).

In SE Hungary, felsic lavas might occur only in the Tótkomlós-I borehole; however, it is more possible that those samples represent the ultimate step of the ignimbrite grade continuum as lava-like ash tuffs.

Felsic volcanic rocks of the Kelebia area are crystal-rich (30-40 vol\%) showing rhyodacitic/dacitic composition and primary pyroclastic origin; however, several textural features suggest that they were affected by Alpine low-grade metamorphism.

On the whole, despite the previous interpretations (Szepesházy 1967; Körössy 2005a,b), Permian felsic rocks in SE Hungary are not lavas, but have pyroclastic origin, showing a wide range of distinct textures as the result of different syn and post 
emplacement textural development. Petrographic observations revealed that in contrast to the previous hypothesis (Szepesházy 1967), there is no relevant plutonic-volcanic connection between the (presumably older) "Battonya granite" and the "Battonya quartzporphyry".

According to the mineralogy and the major element geochemistry, the observed samples in the eastern Pannonian Basin are dominantly rhyolites that was also supported by the immobile element-based rock classification. Only the samples of the Kelebia area showed rhyodacitic/dacitic composition according to the aforementioned observations. Immobile trace elements suggest that all of the studied rocks in SE Hungary could be derived from the same or similar source with those of S Transdanubia. However, the crystal-poor rhyolitic rocks in SE Hungary might represent the most evolved melt of a large-volume felsic volcanic system.

Zircon $\mathrm{U}-\mathrm{Pb}$ ages were obtained from the drill cores of the Tótkomlós-K-3 (2 samples) and the Kelebia-7 boreholes. Zircon dates from the volcanogenic sedimentary rocks and the low-grade metamorphic pyroclastites are interpreted to have $259.5 \pm 2.6$ Ma and 263.7 \pm 2.4 Ma eruption ages, respectively. The latter is in correspondence with the interpreted eruption ages of $\mathrm{S}$ Transdanubia, while the former might represent a younger (probably distinct) volcanic episode.

\subsubsection{The Permian volcanic system forming the Gyürüfü Rhyolite Formation}

Petrographical, geochemical and geochronological observations of the felsic volcanic rocks classified into the Gyürüfü Rhyolite Formation in Hungary pointed out that all the studied samples represent a Mid-Permian ( 267-260 Ma, Guadalupian), rhyodacitic/dacitic to rhyolitic volcanic system. The most common products of the volcanism are rhyodacitic/dacitic (S Trandsdanubia and the Kelebia area, SE Hungary) and rhyolitic (Battonya area, SE Hungary) pyroclastic rocks, while subvolcanic rocks/lavas (northern foreland of the Villány Mts, S Transdanubia) and volcanic sediments (Biharugra and Tótkomlós areas, SE Hungary) are local and subordinate. The Permian felsic magmatism could be associated with an extensional setting succeeding the post-collisional environment like in other areas of the European Variscides. As the Gyürüfü Rhyolite Formation is dominantly represented by pyroclastic rocks (in case of its single outcrop as well) and not lavas as it was previously thought, the name and description of the lithostratigraphic unit should be revised. The new name should 
represent its explosive volcanic origin (i.e., Gyürüfü Dacite/Rhyodacite Lapilli Tuff or Welded Lapilli Tuff). Its role as a marker horizon within the thick Permo-Carboniferous sedimentary sequences should be reconsidered, too, as the formation covers several million years, but it is definately not Lower Permian, contrary to the previous hypotheses.

\subsection{Outlook}

Besides revision and refinement of the information published in the Hungarian geological literatures, the Gyürüfü Rhyolite Formation was also studied during the $\mathrm{PhD}$ research in order to gain new results for the local to regional correlation of the Tisza Mega-unit. Felsic volcanic rocks are crucial in the Late Palaeozoic sequences when it comes to correlational studies as they are comparable (e.g., petrography, major and trace element geochemistry) and suitable for dating by zircon $\mathrm{U}-\mathrm{Pb}$ age determinations among the sedimentary formations. In this subsection, 'regional' means the correlation in the Carpathian-Pannonian region (e.g., Central Transdanubia, Central Western Carpathians, Apuseni Mts), while 'local' means the correlation within the Tisza Mega-unit, reconsidering how Permian felsic volcanic rocks correspond to the traditional subdivision (Alpine facies zones) of the mega-unit.

\subsubsection{Regional correlation in the Carpathian-Pannonian region}

Regarding a broader correlation, the radiometric ages of the Gyürüfü Rhyolite Formation are significantly younger than the zircon ages of other well-studied parts of the Central European Variscides (e.g., Intra-Sudetic Basin, NE Germany), where much older ages were detected ( 300-280 Ma) and different geochemical patterns (especially in case of the immobile trace elements) were observed (Breitkreuz and Kennedy 1999; Wilson et al. 2004; Awdankiewicz and Kryza 2010; Repstock et al. 2017; Słodczyk et al. 2018). However, in the Carpathian-Pannonian region some important correlations were revealed.

In the area of the Tisza Mega-unit, Permian felsic volcanic rocks are well-known in the Apuseni Mts (Codru and Biharia Nappe Systems), Romania where they occur in similar lithostratigraphic positions (among intramontane molasse siliciclastic rocks) to such as in S Transdanubia (Seghedi et al. 2001; Nicolae et 2014). Whole-rock composition (including REEs and other immobile elements) of the studied rocks of the Gyürüfü Rhyolite supports their correlation with the felsic pyroclastic rocks in the 
Apuseni Mts. Zircon $\mathrm{U}-\mathrm{Pb}$ datings were perfomed on various samples of the Apuseni Mts as well, collected during the doctoral research, including rhyodacitic/dacitic ignimbrites in the Finiş, the Dieva, the Moma (Codru Nappe System) and the Arieşeni and the Gârda Nappes (Biharia Nappe System) as well as rhyolitic dykes in the HighişMuncel Nappe (Biharia Nappe System). Their radiometric ages vary between $\sim 269$ and 264 Ma (e.g., Szemerédi et al. 2018a, 2019a, 2020c), overlapping with those of the Gyürüfü Rhyolite Formation. The complex analyses of the Gyürüfü Rhyolite and the similar studies of the related rocks in the Apuseni Mts (e.g., Nicolae et al. 2014; Szemerédi et al. 2018a) as well as all the available information (trace element geochemistry and zircon U-Pb geochronology; Pană et al. 2002; Pál-Molnár et al. 2008) about the granitoid rocks in the Highiş massif (SW Apuseni Mts) pointed to a potential volcanic-plutonic connection among the abovementioned formations (Szemerédi et al. 2019a). Based on preliminary results (Szemerédi et al. 2020c), not only granites, but also diorites in the Highiş massif as well as andesites and basalts in the Codru Nappe System (Dieva and Moma Nappes, Codru-Moma Mts, representing a bimodal volcanic suite) bear similar geochemical patterns (e.g., immobile element enrichment and depletion) and show similar zircon U-Pb ages (granites: $268 \mathrm{Ma}$, diorites: $265 \mathrm{Ma}$ ). On the whole, it feasible that the Gyürüfü Rhyolite and related rocks represent a complex, cogenetic Mid-Permian ( 269-259 Ma, Guadalupian) magmatic system in the Tisza Mega-unit (Hungary and Romania). The detailed study of the latter, focusing on the plutonicvolcanic connections is one of the future plans associated with this $\mathrm{PhD}$ research.

Permian felsic volcanic rocks occur in Central Transdanubia (ALCAPA Megaunit), too, exposed by boreholes in the Balaton Highland and as dykes in the crystalline limestone quarry near Polgárdi. These rocks are classified into the Kékkút Dacite Formation in the Hungarian lithostratigraphy. Samples of this formation were also studied in the $\mathrm{PhD}$ research and compared to the Gyürüfü Rhyolite. It was revealed that they differ in REE and other immobile element patterns as well as zircon $\mathrm{U}-\mathrm{Pb}$ ages. Permian felsic volcanic rocks in this area represent a distinct, significantly older $(\sim 281 \mathrm{Ma}$, Cisuralian) volcanic episode.

Regarding the regional correlation, the crustal-scale superunits of the Central Western Carpathians, Slovakia (ALCAPA Mega-unit) were observed, as well. In this area several geochemical and geochronological studies were performed recently (Vozárová et al. 2009, 2015, 2016; Ondrejka et al. 2018). Among the numerous comparable data, the Gyürüfü Rhyolite showed striking similarity to the Permian felsic volcanites of the 
Southern Gemeric Unit; however, the latter are a little bit older ( 275-273 Ma; Vozárová et al. 2009). Moreover, significant similarity was found among the zircon $\mathrm{U}-\mathrm{Pb}$ ages of the Gyürüfü Rhyolite and those of the Permian felsic volcanic rocks in the Silicic Unit (269-263 Ma, Ondrejka et al. 2018). On the whole, the Gyürüfü Rhyolite proved to be similar to the Permian volcanic rocks in the Western Carpathians. It is correspondent with the paleogeographic reconstructions (e.g., Haas et al. 1999), according to those the Tisza Mega-unit and all the abovementioned crustal-scale superunits could have been situated on the southern margin of the European plate during the Permian.

\subsubsection{Recondsideration of the Mesozoic facies zones in the Tisza Mega-unit}

According to the traditional subdivision of the Tisza Mega-unit, which is based on its Mesozoic evolution (Alpine nappe stacking), the Villány-Bihor Unit was correlated with the Bihor Autochtone Unit (Apuseni Mts), while the Békés-Codru Unit with the Codru Nappe System (Apuseni Mts). On the other hand, the Mecsek Unit and the Biharia Nappe System (Apuseni Mts) have no Alpine correspondence (Szederkényi et al. 2013). However, several achievements of this PhD study suggested that these well-accepted correlations are not always reliable and do deserve some reconsiderations, e.g., in the aspect of Palaeozoic formations. Thereby, the samples of the Gyürüfü Rhyolite and similar volcanic rocks in the Apuseni Mts, Romania were applied to make some preliminary implications for the local correlation of the Tisza Mega-unit.

As most of these felsic volcanic rocks are geochemically rather uniform and possibly belong to the same ( 269-259 Ma) volcanic episode, basically the unique petrographic features (e.g., garnet-bearing, crystal-rich/poor, low-grade metamorphic) were under focus in order to imply some correlations (Table V.1).

Evidently, one characteristic feature of the volcanic rocks is the occurrence of garnet crystals, observed in the samples of the Finiş Nappe (Codru Nappe System) and the northern foreland of the Villány Mts (Villány-Bihor Unit), suggesting that they might be in relationship with each other, in contrast to the traditional Bihor Autochtone Unit Villány-Bihor Unit correlation (Table V.1). Moreover, preliminary SEM and electron microprobe analyses of garnet crystals from the aforementioned tectonic units revealed similar homogeneous (almandine) composition (e.g., Szemerédi et al. 2019b) supporting their common source. Whereas in the Codru Nappe System crystal-rich ignimbrites occur (Nicolae et al. 2014; Szemerédi et al. 2018a), the associated Békés-Codru Unit is 
represented by crystal-poor (rheo)ignimbrites and younger ( $259 \mathrm{Ma})$ volcanic sediments, none of which occur in any other parts of the Tisza Mega-unit. All the aforementioned results suggest that in the aspect of the Permian volcanism, the Codru Nappe System gives the most fitting correlation to the Villány-Bihor and not the BékésCodru Unit (Table V.1).

Table V.1 Correlation between the Alpine facies zones of the Tisza Mega-unit (Hungary) and the tectonic units of the Apuseni Mts (Romania) in the aspect of the Permian felsic volcanic rocks. Data are based on Szederkényi (2013), Nicolae et al. (2014) and all the new results associated with the doctoral research (e.g., Szemerédi et al. 2018b, 2020c)

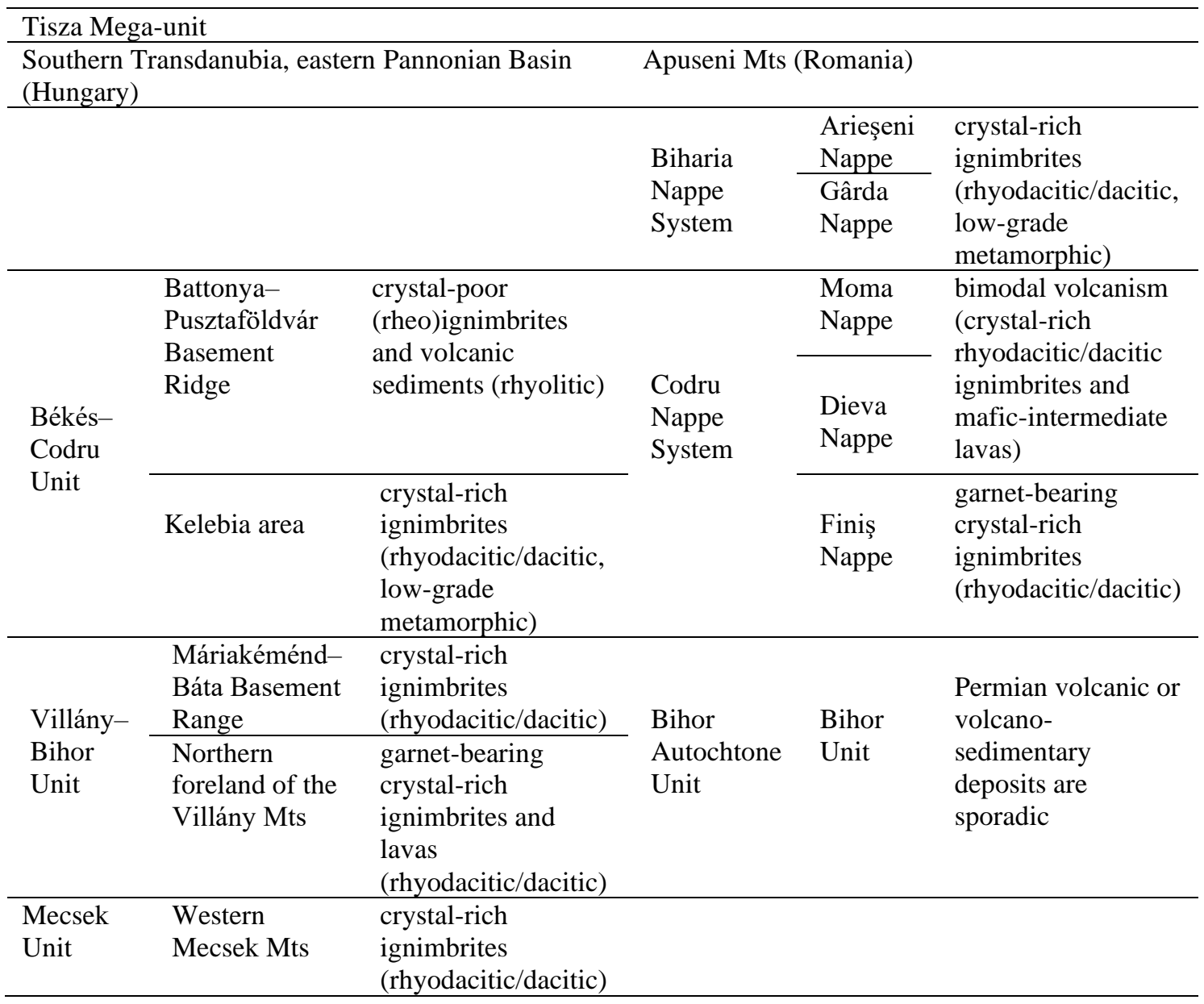

Alpine low-grade metamorphism is a common feature of the Biharia Nappe System in the Apuseni Mts (Pană et al. 2002; Ciobanu et al. 2006; Nicolae et al. 2014). Low-grade metavolcanites occur in the Gârda Nappe (Biharia Nappe System) as well as similar rocks were found in the Kelebia area (Békés-Codru Unit; Raucsik et al. 2016, 2019; Szemerédi et al. 2018b). Moreover, the latter do not resemble to any other samples occurring in the Békés-Codru Unit. It means that the Biharia Nappe System might continue in the basement of S-SE Hungary (Figure V.1 and Table V.1). 


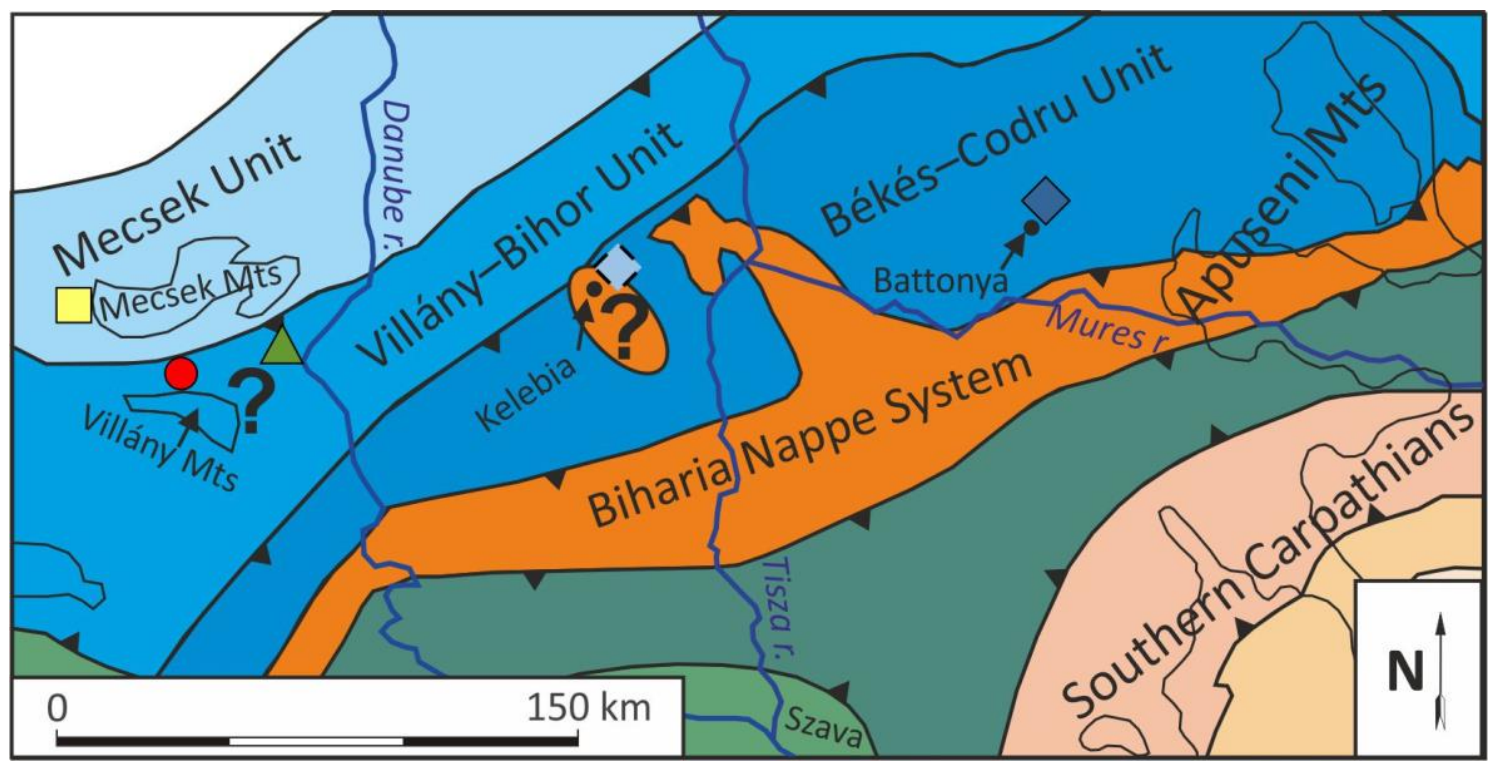

Figure V.1 A possible correlation between the Mesozoic facies zones in the basement of the Tisza Megaunit (Hungary) and the similar structural zones in the Apuseni Mts (Romania), highlighting the new results of the Kelebia area. Symbols used for the subsurface occurrences of the Gyürüfü Rhyolite Formation are as those in Chapter IV. Map base is modified after Matenco and Radivojević (2012)

All the aforementioned statements should draw the attention that the traditional, well-accepted subdivision of the Tisza Mega-unit is not completely reliable, and the present-day boundaries of its tectonic units should be reconsidered. Coming up with a detailed local correlation study is another possible continuation of this topic. 


\section{SUMMARY}

\section{Introduction and aims}

The Gyürüfü Rhyolite Formation is the only magmatic association within the thick Permo-Carboniferous intramontane molasse sequence of the Tisza Mega-unit (Hungary). The formation crops out in the Western Mecsek Mts, Southern Transdanubia; however, it was penetrated by uranium ore (S Transdanubia) and hydrocarbon exploration (eastern Pannonian Basin, SE Hungary) boreholes during the second half of the 20th century. Based on these wells, the following principal subsurface areas of the Gyürüfü Rhyolite were separated: (1) the Western Mecsek Mts, (2) the northern foreland of the Villány Mts and (3) the Máriakéménd-Báta Basement Range in S Transdanubia as well as (4) the Kelebia area and (5) the Battonya-Pusztaföldvár Basement Ridge in the eastern Pannonian Basin. Recognition of the volcanic rocks was associated with the previous reports of the exploration works (e.g., Szederkényi 1962; Szepesházy 1967; Fazekas 1978; Barabásné Stuhl 1988), according to which the formation was basically interpreted as rhyolitic lava ('quartz-porphyry'), while other lithologies (e.g., pyroclastite, subvolcanic rock) were supposed to be subordinate.

The possible pyroclastic origin was already raised in the early stage of the research (Pantó in Boczán et al. 1966) and more than 40 years later supported by petrographic studies (e.g., Varga 2009; Hidasi et al. 2015). Based on the identification of oriented, devitrified pumices (fiammes) in the drill cores and the gravel material in the Western Mecsek Mts, suggesting unequivocally pyroclastic (ignimbrite) origin, the attention was drew to the significance of the reconsideration of archive reports. Besides the question of the dominant eruption style (effusive or explosive), limited geochemical information and no zircon $\mathrm{U}-\mathrm{Pb}$ datings were available for the Gyürüfü Rhyolite. The latter are important regarding the stratigraphic marker role of the formation (supposed to be a Lower Permian horizon) in the Late Palaeozoic sedimentary sequences.

Thus, the major aims of the $\mathrm{PhD}$ research were (1) the petrographic (re)examination of almost all the available drill cores and outcrops (including archive samples and the associated reports), (2) the geochemical analyses (including major and trace elements) of the samples and (3) to obtain the crucial zircon $\mathrm{U}-\mathrm{Pb}$ radiometric ages. The new results were integrated at larger-scale in order to explore the Permian magmatic system of the Gyürüfü Rhyolite (source, geotectonic setting, eruption styles, volcanic eposides etc.). Moreover, the results were compared to those of the other Permian felsic 
volcanic rocks in the Central European Variscides (especially in the CarpathianPannonian region, e.g., Central Transdanubia, Central Western Carpathians, Apuseni Mts) to come up with the preliminary results of the local to regional correlation of the Tisza Mega-unit.

\section{Applied methods}

Almost all the available drill cores and outcrop rock samples of the Gyürüfü Rhyolite Formation were targeted by petrographic observations and reinterpreted, using archive data (e.g., drilling reports) of the previous uranium ore and hydrocarbon exploration works. Drill core (hand specimen and thin section) collections include those of (1) the Department of Mineralogy, Geochemistry and Petrology, University of Szeged, (2) the Department of Petrology and Geochemistry, Eötvös Loránd University and (3) the Mecsek Ore Mining Company (present-day Mecsekérc Ltd.). Petrographic observations were done at the Department of Mineralogy, Geochemistry and Petrology, University of Szeged using Brunel SP-300-P and Olympus BX41 polarizing microscopes.

A total of 18 samples were selected for whole-rock geochemistry representing all the outcrop and subsurface occurrences of the Gyürüfü Rhyolite. These specimens were powdered and analyzed at the Bureau Veritas Mineral Laboratories (AcmeLabs, Vancouver, Canada) by ICP-ES (major elements) and ICP-MS (trace elements including rare earth elements).

Moreover, zircon crystals were separated (standard heavy mineral seperation method including crushing, sieving, heavy liquid separation, magnetic separation and hand picking) from five samples of the Gyürüfü Rhyolite representing its outcrop locality and three distinct subsurface areas. Cathodoluminescence mapping was done at the Department of Petrology and Geochemistry, Eötvös Loránd University using an AMRAY 1830 scanning electron microscope equipped with a GATAN MiniCL. In situ U-Pb radiometric age determinations were performed at the ETH, Zürich, Switzerland and the Georg-August University, Göttingen, Germany by Réka Lukács and István Dunkl, respectively.

\section{New scientific results}

T1 Based on the detailed textural observation of the outcrop rock samples of the Permian Gyürüfü Rhyolite Formation (Gyürüfü area, Western Mecsek Mts), several characteristic 
features of pyroclastic rocks (e.g., devitrified fiammes, altered glass shards, poor sorting, broken phenocrysts, lithic clasts) were identified. The abovementioned features refer to pumiceous pyroclastic flow (ignimbrite) origin of the studied rocks. According to the deformation of the juvenile components, two distinct lithofacies have been separated among the observed samples: (1) eutaxitic, welded and (2) non-welded crystal-rich, pumice-bearing lapilli tuffs. The former might represent the moderate to greater depths of the proximal part of a valley-filling pyroclastic flow, while the latter could be derived from its upper, lowermost, sideward or distal part. My observations conflict the traditional lava interpretation of the Gyürüfü Rhyolite (e.g., uranium ore exploration works) in the study area and support the explosive eruption origin of the drill cores from the Western Mecsek Mts.

T2 All the available archive rock samples and thin sections of the Gyürüfü Rhyolite Formation exposed by boreholes at the northern foreland of the Villány Mts (Bisse-1, Egerág-7, Peterd-1, Szalánta-3, Szava-1, Vókány-2) were studied in the light of modern volcanological views. Based on my detailed petrographic observations, felsic pyroclastic rocks (Peterd-1 borehole and the upper volcanic sequences of the Bisse-1, the Egerág-7, the Szalánta-3 and the Vókány-2 boreholes) and lavas/subvolcanic rocks (Szava-1 borehole and the lower volcanic sequences of the Bisse-1, the Egerág-7, the Szalánta-3 and the Vókány-2 boreholes) have been revealed in the study area. My results contradict the previous hypotheses according to which a wide range of volcanic rock types (e.g., volcanic vent facies, 'microgranite porphyry', lavas with tuff intercalations) occur in the study area and the importance of pyroclastic rocks is subordinate. The Permian felsic volcanism at the northern foreland of the Villány Mts could be reconstructed by a more simple model, suggesting the formation of felsic lava domes and associated flow mechanism, afterwards covered by an extensive, probably several hundred metres thick ignimbrite sheet.

T3 All the available rock samples of the Gyürüfü Rhyolite Formation in SE Hungary (Battonya-Pusztaföldvár Basement Ridge), exposed by hydrocarbon exploration boreholes, were observed in details. The following rock varieties have been revealed: devitrified fiamme-bearing welded and rheomorphic ignimbrites (crystal-poor lapilli tuffs, Battonya area), lava-like ash tuffs (Tótkomlós area) and volcaniclastites (Biharugra and Tótkomlós areas). Based on textural features, the phases of re-crystallization for each 
lithofacies were given, as well. Based on my observations, the previous lava ('quartzporphyry') interpretation in the study area has been confuted, too. The studied samples give the most evolved, rhyolitic composition among the Gyürüfü Rhyolite samples suggesting that they represent the most evolved known magma composition of the Permian regional volcanism in the Tisza Mega-unit. Supplemented by zircon U-Pb ages, it was revealed that the Variscan "Battonya granite" and the Permian felsic volcanic rocks of the Battonya area could not be in a plutonic-volcanic connection.

T4 All the available archive and new whole-rock (major and trace elements) geochemical data of the Gyürüfü Rhyolite Formation were interpreted (representing outcrop rock samples and drill cores of the Western Mecsek Mts, the northern foreland of the Villány Mts, the Máriakéménd-Báta Basement Range, the Kelebia area and the BattonyaPusztaföldvár Basement Ridge). It was revealed that the observed rocks were dominantly affected by significant post-magmatic alterations (e.g., K-metasomatism); thus, their major element composition is not suitable for rock classification and genetic interpretations. It has been pointed out that their lithological caterogization is not straitforward and should not be done based solely on the mineralogical and major element compositions.

T5 Based on the trace element (rare earth and high field strength elements) data, all the available felsic volcanic rocks of the Gyürüfü Rhyolite Formation proved to be geochemically similar; thus, their petrogenetic processes could have been similar, too. Immobile element compositions showed that the rocks of Southern Transdanubia (Western Mecsek Mts, northern foreland of the Villány Mts, Máriakéménd-Báta Basement Range) and the Kelebia area are rhyodacites-dacites, while rhyolitic pyroclastic rocks were only exposed by the boreholes in the Battonya-Pusztaföldvár Basement Ridge. Trace element compositions refer to a post-collisional extensional environment which is fitting well to the geotectonic setting (continental rifting) of the analogous formations in the European Variscides.

T6 Zircon crystals were separated and observed (e.g., binocular, back-scattered and cathodoluminescence microscopy) representing samples of all the outcrop and subsurface occurrences of the Gyürüfü Rhyolite Formation. The representative new zircon $\mathrm{U}-\mathrm{Pb}$ ages, being derived from the crystal mounts prepared by myself, were interpreted in the 
aspect of the Late Palaeozoic evolution of the region. Based on the geochronological results, it was pointed out that the Gyürüfü Rhyolite is the product of Mid-Permian ( 269-260 Ma) magmatic events. The latter contradicts the previous hypotheses, according to which the Gyürüfü Rhyolite was formed by a single volcanic episode and represent a Lower Permian marker horizon. In accordance with the abovementioned results, the lithostratigraphic position of the whole Permian sequence of the Tisza Mega-unit (especially in Southern Transdanubia) should be reconsidered and modified.

T7 Based on the complex results, besides the local correlation, the regional correlation of the Gyürüfü Rhyolite Formation was performed, as well. It was proved that there is no genetic connection between the Gyürüfü Rhyolite and the other well-known Permian felsic volcanic formation in Hungary, the so-called Kékkút Dacite (Central Transdanubia, ALCAPA Mega-unit). Based on my observations, the latter is the result of an older ( $281 \mathrm{Ma}$ ), Lower Permian, geochemically distinct magmatic event. However, close relationship has been found between the Permian felsic volcanic rocks of the Apuseni Mts (Tisza Mega-unit) and the Gyürüfü Rhyolite that might represent the same or similar magmatic system. Moreover, the theory has been raised that the abovementioned rocks could be in a volcanic-plutonic connection with the Permian ( 268-264 Ma) granitoid rocks of the Highiş massif (SW Apuseni Mts). However, the verification of this connection needs further studies and evidence. Slighter correlations were found between the Gyürüfü Rhyolite and the Permian felsic volcanic rocks in the Central Western Carpathians (Silicic and Southern Gemeric Units). 


\section{ÖSSZEGZÉS}

\section{Bevezetés és célkitüzések}

A Tiszai-főegység nagyvastagságú, intramontán molassz üledékekből felépülő permokarbon rétegsorában a Gyürüfüi Riolit az egyetlen magmás kőzetasszociáció. Bár a formáció csak a Dél-Dunántúlon, a Nyugati-Mecsekben bukkan felszínre, a kifejlődéseit harántoló uránérc- (Dél-Dunántúl) és szénhidrogén-kutató (Alföld aljzata, DK-Magyarország) mélyfúrások mégis a hazai paleozoos rétegtan egyik közismert formációjává tették. A fúrások alapján a Gyürüfüi Riolit következő elterjedési területeit különítették el: (1) a Nyugati-Mecsek, (2) a Villányi-hegység északi előtere és (3) a Máriakéménd-Báta közötti terület a Dél-Dunántúlon, illetve (4) a kelebiai terület és (5) a Battonya-Pusztaföldvár aljzati hát a DK-i országrészben. A permi savanyú vulkáni kőzetek megismerése alapvetően a korábbi nyersanyagkutatási jelentésekhez kapcsolódott (pl. Szederkényi 1962; Szepesházy 1967; Fazekas 1978; Barabásné Stuhl 1988), amelyek főként riolitos összetételü lávakőzetként („kvarcporfír”) értelmezték a formációt. Ezzel szemben egyéb litológiák (pl. piroklasztit, szubvulkáni/telér kifejlődés) szerepét alárendeltnek vélték.

Mindezekkel szemben a formáció piroklasztit eredetét már a nyersanyagkutatások korai szakaszában felvetették (Pantó in Boczán 1966), és a közelmúlt petrográfiai vizsgálataival is alátámasztották, pl. a Nyugati-Mecsek területén (Varga 2009; Hidasi et al. 2015). Az említett térség mélyfúrás- és kavicsanyagának vizsgálata során irányítottan elhelyezkedő, ellaposodott, devitrifikált horzsakövek (fiammék) kerültek azonosításra, amelyek egyértelmüen piroklaszt-ár (ignimbrit) eredetre utalnak, és az archív értelmezések újragondolására hívják fel a figyelmet. A domináns vulkáni müködéstípus (effuzív vagy explozív) kérdésköre mellett, korlátozott mennyiségű geokémiai információ állt rendelkezésre a Gyürüfüi Riolitról, illetve cirkon U-Pb radiometrikus kormérések sem történtek a formáció kőzetanyagából. Utóbbiak a képződmény ún. regionális marker horizont szerepének megerősítése szempontjából kulcsfontosságúak, hiszen a hazai szakirodalmak azt egy egységes, alsó-perm rétegtani szintként kezelik.

Doktori kutatásom fö célkitüzései ezáltal a következők voltak: (1) a Gyürüfüi Riolit Formációba sorolt legtöbb rendelkezésre álló fúrómag és felszíni minta petrográfiai (újra)vizsgálata és összeegyeztetése a korábbi nyersanyagkutatási jelentésekben leírtakkal, (2) a kőzetek teljes-kőzet (fö- és nyomelem) geokémiai vizsgálata, illetve (3) cirkon $\mathrm{U}-\mathrm{Pb}$ radiometrikus korhatározás előkészítése (szeparálás, mintakészítés és 
cirkonvizsgálat) a formáció kőzetanyagaiból. Az eredmények nagyobb léptékben is értelmezésre kerültek, a Gyürüfüi Riolit permi magmás rendszerének (forrás, geotektonikai környezet, vulkáni müködés és fázisok) feltárása céljából. Mindemellett a Gyürüfüi Riolit Formáció az európai Variszcidák területéről (különösen a KárpátPannon-térségből, pl. Közép-Dunántúl, Központi-Nyugati-Kárpátok, Erdélyiközéphegység) ismert más permi savanyú vulkanitokról rendelkezésre álló információkkal is összevetésre került. Az összehasonlításoknak köszönhetően a Tiszaiföegység megbízható lokális-regionális korrelációjában is alkalmazható, új eredményeket sikerült felmutatnom.

\section{Alkalmazott módszerek}

A disszertációban a Gyürüfüi Riolit Formáció rendelkezésre álló felszíni- és fúrásanyagának jelentős része leírásra és (újra)értelemzésre került, a korábbi uránérc- és szénhidrogén-kutatási jelentések alapos átvizsgálásával egyetemben. A tanulmányozott fúrásanyag (fúrómag és vékonycsiszolat) gyüjtemények a következő intézményekhez kapcsolódnak: (1) SZTE Ásványtani, Geokémiai és Kőzettani Tanszék, (2) ELTE Kőzettan-Geokémiai Tanszék és a (3) Mecseki Ércbányászati Vállalat (ma Mecsekérc Zrt.). Petrográfiai vizsgálataimat az SZTE Ásványtani, Geokémiai és Kőzettani Tanszéken végeztem Brunel SP-300-P és Olympus BX41 típusú polarizációs mikroszkópokat használva.

Összesen $18 \mathrm{db}$ mintából készültek teljes-kőzet (fö- és nyomelem) geokémiai elemzések, amelyek a Gyürüfüi Riolit felszíni- és fúrásanyagait (beleértve valamennyi felszín alatti elterjedési területet) egyaránt képviselik. A vizsgálatok a Bureau Veritas Mineral Laboratories (AcmeLabs, Vancouver, Kanada) laboratóriumában készültek; a főelem-koncentrációk meghatározása ICP-ES-sel, míg a nyomelemeké (beleértve a ritkaföldfémeket is) ICP-MS-sel történt.

Továbbá a Gyürüfüi Riolit Formáció 4 különböző felszíni és felszín alatti elterjedési területének 5 db kőzetmintájából radiometrikus korhatározás céljából cirkon kristályokat szeparáltam (standard nehézásvány szeparálás: törés, szitálás, nehézfolyadékos leválasztás, mágneses szeparálás és kézi kiválogatás). A cirkon kristályok katódlumineszcens térképezése az ELTE Kőzettan-Geokémiai Tanszéken történt egy GATAN MiniCL-lel felszerelt AMRAY 1830 típusú pásztázó elektronmikroszkóp használatával. Az in-situ U-Pb korméréseket Lukács Réka és Dunkl 
István végezték, a zürichi ETH (Svájc), illetve a Göttingeni Egyetem (Németország) laboratóriumaiban.

\section{Az eredmények tézisszerü összefoglalása}

T1 A permi Gyürüfüi Riolit Formáció felszíni kőzetanyagában (Nyugati-Mecsek, Gyürüfü térsége) számos, egyértelműen a piroklasztitokra jellemző szöveti bélyeget azonosítottam (pl. devitrifikálódott fiammék, egykori üvegszilánkok, rossz osztályozottság, töredezett fenokristályok, litoklasztok), amelyek a képződmény horzsakő- és hamuár (ignimbrit) eredetére utalnak. A juvenilis elegyrészeket ért deformáció szerint a kőzeteket két litofáciesre osztottam: (1) eutaxitos szövetü, összesült és (2) nem összesült, kristálygazdag, horzsakőtartalmú lapillitufákra. Előbbi minták az egykori völgyet feltöltő piroklaszt-ár proximális, míg utóbbiak annak felső, legalsó, oldalsó vagy disztális részét képviselhetik. Vizsgálataimmal cáfoltam a névadó területen a Gyürüfüi Riolit hagyományos lávakőzet értelmezését (pl. uránérc-kutatási jelentések), ugyanakkor megerősítettem a nyugati-mecseki fúrómagminták vizsgálati eredményei alapján alkotott újabb hipotéziseket.

T2 A Villányi-hegyég északi előterének mélyfúrásai (Bisse-1, Egerág-7, Peterd-1, Szalánta-3, Szava-1, Vókány-2) által feltárt és a Gyürüfüi Riolit Formációba sorolt archív kőzetminták és vékonycsiszolatok modern szemléletű leírását végeztem el. Részletes petrográfiai vizsgálataim eredménye alapján a területen savanyú piroklasztitokat (Peterd1 mélyfúrás, ill. a Bisse-1, az Egerág-7, a Szalánta-3 és a Vókány-2 fúrások felső vulkáni szakaszai) és lávákat/szubvulkáni kőzeteket (Szava-1 mélyfúrás, ill. a Bisse-1, az Egerág7, a Szalánta-3 és a Vókány-2 fúrások alsó vulkáni szakaszai) sikerült elkülönítenem. Vizsgálataim ellentmondanak a korábbi feltételezéseknek, amelyek szerint a területen rendkívül változatos vulkáni kőzettípusok (pl. kürtőfácies, „mikrogránit porfír”, lávák és közbetelepült tufák) jelennek meg a piroklasztitok alárendelt szerepével. A Villányihegység északi előterének permi vulkanizmusa egy egyszerübb modellel, savanyú lávadómok felépülésével és lávaár müködéssel, illetve egy kiterjedt, - az említett központokat befedő - akár több 100 m-es vastagságú ignimbrit takaróval rekonstruálható.

T3 A DK-Magyarországon (Battonya-Pusztaföldvár aljzati hát) szénhidrogén-kutató fúrások által feltárt és a Gyürüfüi Riolit Formációba sorolt vulkáni kőzetek valamennyi 
rendelkezésre álló mintájának részletes petrográfiai vizsgálatát elvégeztem. A területen a következő kőzettípusokat azonosítottam: devitrifikálódott fiamméket tartalmazó, összesült és reomorf ignimbritek (kristályszegény lapillitufák, Battonya térsége), lávaszerü átkristályosodott tufák (Tótkomlós térsége) és vulkanoszedimentek (Biharugra és Tótkomlós térsége). Az egyes litofáciesekre vonatkozóan - szöveti bélyegek alapján az átkristályosodás lehetséges fázisait is felvázoltam. Eredményeim alapján cáfoltam a korábbi lávakőzet („kvarcporfír”) értelmezést az adott területen. A vizsgált minták a Gyürüfüi Riolithoz tartozó kőzetek között a legfejlettebb, riolitos összetételt adják, így a regionális vulkanizmus legfejlettebb ismert magmáját képviselik. Cirkon $\mathrm{U}-\mathrm{Pb}$ koradatokkal kiegészítve megállapítottam, hogy a variszkuszi battonyai gránit és a battonyai permi savanyú vulkanitok nem állhatnak egymással plutoni-vulkáni kapcsolatban.

T4 A Gyürüfüi Riolit Formáció összes ismert hazai felszíni és felszín alatti előfordulási területéröl (Nyugati-Mecsek, Villányi-hegység északi előtere, Máriakéménd-Báta közötti terület, Kelebia térsége és Battonya-Pusztaföldvár aljzati hát) rendelkezésre álló archív és új teljes kőzet (fö- és nyomelem) geokémiai adat értelmezését elvégeztem. Megállapítottam, hogy a vizsgált kőzetek általában jelentős mértékű utólagos átalakuláson (pl. kálimetaszomatózis) estek át, így főelem-összetételük kémiai osztályozásra és genetikai információk levonására nem alkalmas. Rámutattam arra, hogy mindezek alapján a képződmény kőzettani megnevezését (riolit vagy dácit) nem lehet az ásványos- és főelem-összetétel alapján egyértelműen megtenni.

T5 A Gyürüfüi Riolit Formáció összes ismert hazai előfordulási területének kőzetanyagain végzett nyomelem-geokémiai elemzések (ritkaföldfémek és nagy térerejü nyomelemek) adatai alapján megállapítottam, hogy a savanyú vulkáni kőzetek geokémiailag hasonlóak és hasonló petrogenetikai folyamatokon mehettek keresztül. Immobilis nyomelemtartalom alapján riodácitos/dácitos összetétel jellemzi a DélDunántúl (Nyugati-Mecsek, Villányi-hegység északi előtere, Máriakéménd-Báta közötti terület) és Kelebia térségének kőzeteit, ezzel szemben kizárólag a BattonyaPusztaföldvár aljzati hát mélyfúrásai tártak fel riolitos összetételü piroklasztitokat. A nyomelem-összetétel alapján posztkollíziós extenziós geotektonikai környezetre lehet következtetni, amely kiválóan beleillik az európai Variszcidák analóg képződményeinek keletkezéséről alkotott elképzelésekbe (kontinentális riftesedés). 
T6 $\mathrm{U}-\mathrm{Pb}$ radiometrikus kormérések előkészítéseként cirkon kristályokat szeparáltam és vizsgáltam (pl. binokuláris, visszaszórt elektron- és katódlumineszcens mikroszkópia) a Gyürüfüi Riolit Formáció összes ismert hazai előfordulási területének kőzetanyagából. $\mathrm{Az}$ általam előkészített cirkonmintákból származó reprezentatív új cirkon U-Pb koradatokat a régió fejlődéstörténetének megfelelően értelmeztem. A mérési eredmények alapján megállapítható, hogy a Gyürüfüi Riolit egy középső-permi ( 269-260 millió évvel ezelőtti) magmás esemény eredménye. Ez nincs összhangban azokkal a korábbi feltételezésekkel, hogy a Gyürüfüi Riolit egyetlen vulkáni epizód eredményeként alakult ki, és egy alsó-permi marker horizontot képez. Ennek megfelelően rámutattam arra, hogy a Tiszai-főegység (különösen a Dél-Dunántúl) teljes permi rétegsora litosztratigráfiai szempontból módosításra szorul.

T7 A komplex vizsgálati eredmények alapján - a lokális korreláción túl - regionális korrelációt is végeztem. Bizonyítottam, hogy a Gyürüfüi Riolit Formáció és a hazai rétegtan másik közismert permi vulkáni képződménye, a Kékkúti Dácit (KözépDunántúl, ALCAPA-főegység) között nincs genetikai kapcsolat. Az elvégzett vizsgálatok eredményei alapján utóbbi egy idősebb ( 281 millió évvel ezelőtti), alsó-permi, geokémiailag is különböző magmás esemény eredménye. Ezzel szemben rokonságot mutattam ki az Erdélyi-középhegység (Tiszai-főegység) permi savanyú vulkáni kőzetei és a Gyürüfüi Riolit között, amelyek egyazon vagy hasonló magmás rendszert képviselhetnek. Továbbá felvetettem, hogy az említett kőzetek potenciális vulkániplutoni kapcsolatban állhatnak a Hegyes-hegység (Erdélyi-középhegység DNy-i része) permi ( 268-264 millió éves) granitoidjaival („Hegyesi gránit”). Utóbbi kapcsolat bizonyításához azonban további vizsgálatok szükségesek. Kisebb mértékü korrelációt tapasztaltam a Gyürüfüi Riolit és a Központi-Nyugati-Kárpátok területén (Szilicei-takaró, Dél-Gömörikum) előforduló permi savanyú vulkáni kőzetek között. 


\section{ACKNOWLEDGEMENTS}

First of all, I would like to express my sincere gratitude to my supervisor, Andrea Raucsikné Varga for offering me a research topic in 2013 that served as the base of my bachelor, master and PhD Theses. The new findings of this research year by year were the results of her professional guidance and useful pieces of advice, as well. Her suggestions and careful corrections were essential not only in professional questions, but also in any steps of becoming an early career scientist (e.g., presentation techniques, publication in English, suggestion of journals, conferences, scholarships). I hope that our common work could be an important part of her broader research area, the Late Palaeozoic evolution of the Tisza Mega-unit.

I would like to express the same gratitude to my consultant, Réka Haranginé Lukács (MTA-ELTE Volcanology Research Group, Budapest) for the introduction to the world of zircon $\mathrm{U}-\mathrm{Pb}$ age determinations. Zircon separation and age dating would have been impossible without her work, the consultations at Eötvös Loránd University were always gainful and productive throughout my $\mathrm{PhD}$ studies. I am also very thankful for her efforts to build new professional connections. The collaboration with István Dunkl (Georg-August University, Göttingen, Germany), Ioan Seghedi and Mihai Tatu (Institute of Geodynamics, Romanian Academy, Bucharest, Romania), Gyöngyi Lelkesné Felvári and Marcel Guillong (ETH, Zürich, Switzerland) raised the value of the new findings of the $\mathrm{PhD}$ research, so I am collectively grateful to the abovementioned professionals, too.

I would like to say many thanks to Elemér Pál-Molnár (Department of Mineralogy, Geochemistry and Petrology, University of Szeged) for all of his constructive suggestions during my $\mathrm{PhD}$ studies. Field trips organized by/with him were unequivocally the practically most useful and memorable sessions of my academic period at University of Szeged. He was always open for conversations and any type of questions related to the $\mathrm{PhD}$ research and supported my attendance on several domestic and international conferences, workshops and short courses.

The regional correlation studies as significant part of the $\mathrm{PhD}$ research were supported by the UNKP-17-4, UNKP-18-4-SZTE-16 and UNKP-18-3-I-SZTE-90 New National Excellence Program of the Ministry of Human Capacities (Hungary) to Andrea Raucsikné Varga and myself. Additionally, some parts of the doctoral research were financed by the ongoing National Research, Development and Innovation Fund project K 131690 as well as the Hungarian Scientific Research Fund project K 108375. 
I would like to say many thanks to all the members of the Department of Mineralogy, Geochemistry and Petrology, University of Szeged (head of department: Tivadar M. Tóth). Besides Andrea Raucsikné Varga and Elemér Pál-Molnár, I should namely mention the following colleagues who played important role in this $\mathrm{PhD}$ research, too: Attila Bencsik (thin section preparation), Elöd Mészáros, Béla Raucsik (samplings, consultations, feedbacks), Félix Schubert (SEM analyses at University of Szeged) and Tivadar M. Tóth (consultations, feedbacks).

I would like to express my gratitude to all the members of the MTA-ELTE Volcanology Research Group, Budapest (head of research group: Szabolcs Harangi) for their support in zircon separation, sample (crystal mount) preparation, SEM analyses and the discussions at any meetings/conferences where several feedbacks were gained. Besides Réka Haranginé Lukács and Szabolcs Harangi, János Szepesi, Csaba Vígh, Péter Gál, Ildikó Soós, Ágoston Tóth, Kristóf Fehér and Kata Molnár should be namely mentioned. I would like to say many thanks to the members of the Department of Petrology and Geochemistry, Eötvös Loránd University, including Sándor Józsa and György Szakmány (consultations, feedbacks) as well as Zoltán Kovács and Zsolt Bendö (SEM analyses).

Hungarian and international publications during the $\mathrm{PhD}$ research were reviewed by the following professionals: Sándor Józsa, János Szepesi (articles in Földtani Közlöny), Sándor Szakács (Central European Geology), Axel Gerdes and Albrecht von Quadt (International Journal of Earth Sciences). I would like to express my gratitude to all of them for the constructive suggestions and the corrections.

I would like to say many thanks to those people who always kept me interesed in natural sciences (especially rocks and minerals) since my childhood, including my father, András Szemerédi and my previous Geography teacher, Lajos Cseh (Horváth Mihály Secondary School, Szentes).

I would like to express my gratitude to the very pleasant and supporting everyday environment during my $\mathrm{PhD}$ studies, including all members of the PhD room at the Department of Mineralogy, Geochemistry and Petrology, University of Szeged and my Friends open for conversations, coffees, lunches, drinks and any kind of social programs in Szeged as well as amazing trips in summer, far from Szeged.

I am also very thankful to the following professional youth organizations for the cooperation during my PhD years: AAPG Szeged Student Chapter, Youth Committee of 
the Hungarian Geological Society and Eötvös Loránd University Student Chapter of the Society of Economic Geologists.

Last but not least, my Family deserves a lot of thanks for ensuring me all types of support that I needed during the nine years at University of Szeged. Without their encouraging words during the weekends and holidays in Szentes my professional progress would never be the same. 


\section{REFERENCES}

Allen RL (1988) False Pyroclastic Textures in Altered Silicic Lavas, with Implications for Volcanic-Associated Mineralization. Econ Geol 83:1424-1446. https://doi.org/10.2113/gsecongeo.83.7.1424

Awdankiewicz M (1999) Volcanism in a late Variscan intramontane trough: the petrology and geochemistry of the Carboniferous and Permian volcanic rocks of the IntraSudetic Basin, SW Poland. Geol Sudetica 32:81-111

Awdankiewicz M, Kryza R (2010) The Góry Suche Rhyolitic Tuffs (Intra-Sudetic Basin, SW Poland): preliminary SHRIMP zircon age. Mineralogia Special Papers 37:19 Bachmann O, Bergantz GW (2004) On the origin of crystal-poor rhyolites: extracted from batholithic crystal mushes. J Petrol 45:1565-1582. https://doi.org/10.1093/petrology/egh019

Bachmann O, Bergantz GW (2008) Rhyolites and their Source Mushes across Tectonic Settings. J Petrol 49(12):2277-2285. https://doi.org/10.1093/petrology/egn068

Balogh K, Kovách Á (1973) Determination of the Battonya quartz porphyries age by Rb/Sr method. ATOMKI Közl. 15(4):245-249 (in Hungarian with English abstract)

Barabásné Stuhl Á (1988) A Dél-Baranyai dombság és a Villányi hegység permi képződményeinek kutatásáról készített összefoglaló jelentés IV. fejezete a permi képződményekről. Mecsekérc Ltd. (former Mecsek Ore Mining Company), pp 100-213 (in Hungarian)

Barabás A, Barabásné Stuhl Á (1998) A Mecsek és környéke perm képződményeinek rétegtana. In: Bérczi I, Jámbor Á (eds): Magyarország geológiai képződményeinek rétegtana. MOL Rt. - MÁFI publication, Budapest, pp 187-215 (in Hungarian)

Black LP, Kamo SL, Allen CM, Davis DW, Aleinikoff JN, Valley JW, Mundil R, Campbell IH, Korsch RJ, Williams IS, Foudoulis C (2004) Improved 206Pb/238U microprobe geochronology by the monitoring of a trace-element-related matrix effect; SHRIMP, ID-TIMS, ELA-ICP-MS and oxygen isotope documentation for a series of zircon standards. Chem Geol 205(1):115-140. https://doi.org/10.1016/j.chemgeo.2004.01.003

Boczán B, Franyó F, Frits J, Láng S, Moldvay L, Pantó G, Rónai A, Stefanovits P (1966) M-34-XXXIV. Sátoraljaújhely. Magyarázó Magyarország 200 000-es földtani térképsorozatához. MÁFI, Budapest (in Hungarian) 
Branney MJ, Kokelaar P (1992) A repappraisal of ignimbrite emplacement: progressive aggradation and changes from particulate to non-particulate flow during emplacement of high-grade ignimbrite. Bull Volcanol 54:504-520. https://doi.org/10.1007/bf00301396

Branney M, Kokelaar JP (2002) Pyroclastic density currents and the sedimentation of ignimbrites. Geological Society Memoir No. 27, The Geological Society, London. https://doi.org/10.1086/427850

Branney MJ, Kokelaar BP, McConnell BJ (1992) The Bad Step Tuff: a lava-like rheomorphic ignimbrite in a calc-alkaline piecemeal caledera, English Lake District. Bull Volcanol 54:187-199. https://doi.org/10.1007/bf00278388

Breitkreuz C (2013) Spherulites and lithophysae - 200 years of investigation on hightemperature crystallization domains in silica-rich volcanic rocks. B Volcanol 75:705. https://doi.org/10.1007/s00445-013-0705-6

Breitkreuz C (2015) Introduction to physical volcanology and volcanic textures. Short course guide, TU Bergakademie, Freiberg

Breitkreuz C, Kennedy A (1999) Magmatic flare-up at the Carboniferous/Permian boundary in the NE German Basin revealed by SHRIMP zircon ages. Tectonophysics 302:307-326. https://doi.org/10.1016/s0040-1951(98)00293-5

Brown RJ, Bonadonna C, Durant AJ (2012) A review of volcanic ash aggregation. Phys Chem Earth 45-46:65-78. https://doi.org/10.1016/j.pce.2011.11.001

Christiansen EH (2005) Contrasting processes in silicic magma chambers: Evidence from very large volume ignimbrites. Geol Mag 142:669-681. https://doi.org/10.1017/s0016756805001445

Christiansen EH, McCurry M (2008) Contrasting origins of Cenozoic silicic rocks from the western Cordillera of the United States. B Volcanol 70(3):251-267. https://doi.org/10.1007/s00445-007-0138-1

Condie KC (1993) Chemical composition and evolution of the upper continental crust: Contrasting results from surface samples and shales. Chem Geol 104:1-37. https://doi.org/10.1016/0009-2541(93)90140-e

Cortesogno L, Cassinis G, Dallagiovanna G, Gaggero L, Oggiano G, Ronchi A, Seno S, Vanossi M (1998) The post-Variscan volcanism in the Late CarboniferousPermian sequences of Ligurian Alps, Southern Alps and Sardinia. Lithos 45:305328. https://doi.org/10.1016/s0024-4937(98)00037-1 
Ciobanu CL, Cook NJ, Damian F, Damian G (2006) Gold scavenged by bismuth melts: An example from Alpine shear-remobilizates in the Highiş Mts, Romania. Mineral Petrol 87:351-384. https://doi.org/10.1007/s00710-006-0125-9

Császár G (2005) Magyarország és környezetének regionális földtana, I. Paleozoikum paleogén. Eötvös University Press, Budapest (in Hungarian)

Dostal J, Vozár J, Keppie JD, Hovorka D (2003) Permian volcanism in the Central Western Carpathians (Slovakia): Basin-and-Range type rifting in the southern Laurussian margin. Int J Earth Sci 92:27-35. https://doi.org/10.1007/s00531-0020307-6

Dunkl I, Mikes T, Simon K, von Eynatten H (2008) Brief introduction to the Windows program Pepita: data visualization, and reduction, outlier rejection, calculation of trace element ratios and concentrations from LA-ICP-MS data. In: Sylvester P (ed) Laser ablation ICP-MS in the Earth Sciences: Current practices and outstanding issues. Mineralogical Association of Canada, pp 334-340

Ennis DJ, Dunbar NW, Campbell AR, Chapin CE (2000) The effects of K-metasomatism on the mineralogy and geochemistry of silicic ignimbrites near Socorro, New Mexico. Chem Geol 167:285-312. https://doi.org/10.1016/s00092541(99)00223-5

Fazekas V (1978) Kutatási Zárójelentés: A magyarországi felső-paleozoos vulkanitok ásvány-kőzettani-, kémiai-, valamint sugárzóanyag-tartalom vizsgálata. Closing report, Mecsek Ore Mining Company (J-3033) (in Hungarian)

Fazekas V, Vincze J (1991) Hidrotermás ércindikációk a Villányi-hegység északi előtere mélyfúrásaiban. Földtani Közlöny 121:23-56 (in Hungarian)

Fink JH, Manley CR (1987) Origin of pumiceous and glassy textures in rhyolite domes and flows in the emplacement of silicic domes and lava flows. Geological Society of America Special Papers 212:77-89. https://doi.org/10.1130/spe212-p77

Frei D, Gerdes A (2009) Precise and accurate in situ U-Pb dating of zircon with high sample throughput by automated LA-SF-ICP-MS. Chem Geol 261(3-4):261-270. https://doi.org/10.1016/j.chemgeo.2008.07.025

Fülöp J (1990) Magyarország geológiája, Paleozoikum I. (Geology of Hungary, Paleozoic I.). Akadémiai Kiadó, Budapest (in Hungarian)

Fülöp J (1994) Magyarország geológiája, Paleozoikum II. (Geology of Hungary, Paleozoic II.). Akadémiai Kiadó, Budapest (in Hungarian)

Garrels RM, Mackenzie FT (1971) Evolution of sedimentary rocks. Norton, New York 
Gifkins CC, Allen RL, McPhie J (2005a) Apparent welded textures in altered pumicerich rocks. J Volcanol Geoth Res 142:29-47. https://doi.org/10.1016/j.jvolgeores.2004.10.012

Gifkins C, Hermann W, Large R (2005b) Altered volcanic rocks: a guide to description and interpretation. Centre for Ore Deposit Research, University of Tasmania, Australia

Gorton MP, Schandl ES (2000) From continents to island arcs: a geochemical index of tectonic setting for arc-related and within-plate felsic to intermediate volcanic rocks. Canad Mineral 38:1065-1073. https://doi.org/10.2113/gscanmin.38.5.1065

Haas J, Hámor G, Korpás L (1999) Geological setting and tectonic evolution of Hungary. Geologica Hungarica Series Geologica 24:179-196

Haas J, Tait J, Körner F (2008) Permian. In: McCann T (ed) The geology of Central Europe, V1: Precambrian and Paleozoic. Geological Society, London, pp 531597

Harangi Sz, Downes H, Kósa L, Szabó Cs, Thirlwall MF, Mason PRD, Mattey D (2001) Almandine Garnet in Calc-alkaline Volcanic Rocks of the Northern Pannonian Basin (Eastern-Central Europe): Geochemistry, Petrogenesis and Geodynamic Implications. J Petrol 42(10):1813-1843. https://doi.org/10.1093/petrology/42.10.1813

Henry CD, Wolff JA (1992) Distinguishing strongly rheomorphic tuffs from extensive silicic lavas. Bull Volcanol 54:171-186. https://doi.org/10.1007/bf00278387

Hidasi T, Varga A, Pál-Molnár E (2015) Petrographic analysis of Gyürüfü Rhyolite Formation using the thin section collection of Mecsek Ore Company. Földtani Közlöny 145(1):3-22 (in Hungarian with English abstract)

Hildreth W (1981) Gradients in Silicic Magma Chambers: Implications for Lithospheric Magmatism. J Geophys Res-Sol Ea 86:10153-10192. https://doi.org/10.1002/9781118782057.ch3

Horstwood MSA, Košler J, Gehrels G, Jackson SE, McLean NM, Paton C, Pearson NJ, Sircombe K, Sylvester P, Vermeesch P, Bowring JF, Condon DJ, Schoene B (2016) Community-Derived Standards for LA-ICP-MS U-(Th)-Pb Geochronology - Uncertainity Propagation, Age Interpretation and Data Reporting. Geostand Geoanal Res 40:311-332. https://doi.org/10.1111/j.1751908x.2016.00379.x 
Huber C, Bachmann O, Dufek S (2012) Crystal-poor versus crystal-rich ignimbrites: A competition between strirring and reactivation. Geology 40:115-118. https://doi.org/10.1130/g32425.1

Hughes CJ (1972-1973) Spilites, keratophyres, and the igneous spectrum. Geol Mag 109(6):513-527. https://doi.org/10.1017/s0016756800042795

Jackson SE, Pearson NJ, Griffin WL, Belousova EA (2004) The application of laser ablation-inductively coupled plasma-mass spectrometry to in situ $\mathrm{U}-\mathrm{Pb}$ zircon geochronology. Chem $\quad$ Geol 211:47-69. https://doi.org/10.1016/j.chemgeo.2004.06.017

Jakab A (2005) A Gyürüfüi Riolit kőzettani és geokémiai leírása. MSc Thesis, Department of Petrology and Geochemistry, Eötvös Loránd University, Budapest (in Hungarian)

Jiang SY, Wang RC, Xu XS, Zhao KD (2004) Mobility of high field strength elements (HFSE) in magmatic-, metamorphic-, and submarine-hydrothermal systems. Phys Chem Earth 30:1020-1029. https://doi.org/10.1016/j.pce.2004.11.004

Józsa S, Szakmány Gy, Máthé Z, Barabás A (2009) A Mecsek és környéke miocén konglomerátum összletek felszíni elterjedése és a kavicsanyag összetétele. In: M. Tóth T (ed) Magmás és metamorf képződmények a Tiszai Egységben, GeoLitera, Szeged, pp 195-217 (in Hungarian)

Kassai M (1976) A Villányi-hegység előterének perm képződményei. Geologica Hungarica Series Geologica, Budapest (in Hungarian)

Kelemen P, Dunkl I, Csillag G, Mindszenty A, von Eynatten H, Józsa S (2017) Tracing multiple resedimentation on an isolated karstified plateau: The bauxite-bearing Miocene red clay of the Southern Bakony Mountains, Hungary. Sediment Geol 358:84-96. https://doi.org/10.1016/j.sedgeo.2017.07.005

Kohút M, Trubač J, Novotný L, Ackerman L, Demko R, Bartalský B, Erban V (2013) Geology and Re-Os molybdenite geochronology of the Kurišková U-Mo deposit (Western Carphatians, Slovakia). J Geosci 58:275-286. https://doi.org/10.3190/jgeosci.150

Konrád Gy (1981) Egerág-7 sz. mélyfúrás paleozóos rétegeinek földtani leírása. Handwritten report, MÉV Adattár, Pécs (in Hungarian)

Konrád Gy, Sebe K (2010) New details of young tectonic phenomena in the Western Mecsek Mts and their surroundings. Földtani Közlöny 140(2):445-468 (in Hungarian with English abstract) 
Konrád Gy, Földing G, Barabás A, Unyi P (2012) Geology, experimental in situ leaching and site remediation of the Dinnyeberki uranium ore deposit. Földtani Közlöny 142(4):357-374 (in Hungarian with English abstract)

Körössy L (2005a) Hydrocarbon geology of the southeastern Great Plain, Hungary. Part I. Általános Földtani Szemle 29:41-132 (in Hungarian with English abstract)

Körössy L (2005b) Hydrocarbon geology of the southeastern Great Plain, Hungary. Part II. Általános Földtani Szemle 30:7-92 (in Hungarian with English abstract)

Kurucz B (1977) A Pusztaföldvár-Battonya közötti terület medencealjzatának képződményei és hegységszerkezete. doctoral (dr. univ.) thesis, Department of Geology and Paleontology, University of Szeged, Szeged (in Hungarian)

Le Maitre RW, Streckeisen A, Zanettin B, Le Bas MJ, Bonin B, Bateman P (1989) Igneous Rocks: A Classification and Glossary of Terms. Recommendations of the International Union of Geological Sciences Subcomission on the Systematics of Igneous Rocks. Blackwell, Oxford

Lelkes-Felvári Gy, Klötzli U (2004) Zircon geochronology of the "Kékkút quartz porphyry", Balaton Highland, Transdanubian Central Range, Hungary. Acta Geologica Hungarica 47(2-3):139-149. https://doi.org/10.1556/ageol.47.2004.23.4

Letsch D, Winkler W, von Quadt A, Gallhofer D (2014) The volcano-sedimentary evolution of a post-Variscan intramontane basin in the Swiss Alps (Glarus Verrucano) as revealed by zircon $\mathrm{U}-\mathrm{Pb}$ age dating and $\mathrm{Hf}$ isotope geochemistry. Int J Earth Sci 104:123-145. https://doi.org/10.1007/s00531-014-1055-0

Lofgren G (1971) Experimentally produced devitrification textures in natural rhyolitic glass. Geol Soc Am Bull 82:111-124. https://doi.org/10.1130/00167606(1971)82[111:epdtin]2.0.co;2

Ludwig KR (2002) User's manual for Isoplot 3.75: A geochronological Toolkit for Microsoft Excel. Berkeley Geochronology Center Special Publication No. 4

MacKenzie WS, Donaldson CH, Guilford C (1982) Atlas of igneous rocks and their textures. Wiley

Matenco L, Radivojević D (2012) On the formation and evolution of the Pannonian Basin: Constraints derived from the structure of the junction area between the Carpathians and Dinarides. Tectonics 31. https://doi.org/10.1029/2012TC003206 
McArthur AN, Cas RAF, Orton GJ (1998) Distribution and significance of crystalline, perlitic and vesicular textures in the Ordovician Garth Tuff (Wales). Bull Volcanol 60:260-285. https://doi.org/10.1007/s004450050232

McPhie J, Doyle M, Allen R (1993) Volcanic textures: A guide to the interpretation of textures in volcanic rocks. Centre for Ore Deposit and exploration Studies, University of Tasmania, Australia

Máthé Z, Varga A (2012) „Ízesítő” a permi Bodai Agyagkő Formáció őskörnyezeti rekonstrukciójához: kősó utáni pszeudomorfózák a BAT-4 fúrás agyagkőmintáiban. Földtani Közlöny 142(2):201-204 (in Hungarian)

Mattinson JM (2005) Zircon U-Pb chemical abrasion ("CA-TIMS") method: Combined annealing and multi-step partial dissolution analysis for improved precision and accuracy of zircon ages. Chem Geol 220(1):47-66. https://doi.org/10.1016/j.chemgeo.2005.03.011

Morelli C, Bargossi GM, Mair V, Marocchi M, Moretti A (2007) The lower Permian volcanics along the Etsch Valley from Meran to Auer (Bozen). Mitt Oesterr Mineral Ges 153:129-152

Nicolae I, Seghedi I, Boboş I, Azevedo MR, Ribeiro S, Tatu M (2014) Permian volcanic rocks from the Apuseni Mountains (Romania): Geochemistry and tectonic constrains. Chem 74:125-137. https://doi.org/10.1016/j.chemer.2013.03.002

Ondrejka M, Li XH, Vojtko R, Putiš M, Uher P, Sobocký T (2018) Permian A-type rhyolites of the Muraň Nappe, Inner Western Carpathians, Slovakia: in-situ zircon $\mathrm{U}-\mathrm{Pb}$ SIMS ages and tectonic setting. Geol Carpath 69(2):187-198. https://doi.org/10.1515/geoca-2018-0011

Orth K, McPhie J (2003) Textures formed during emplacement and cooling of a Paleoproterozoic, small-volume rhyolitic sill. J Volcanol Geotherm Res 128: 341362. https://doi.org/10.1016/s0377-0273(03)00200-2

Pál-Molnár E, András E, Kassay Zs, Buda Gy, Batki A (2008) Petrology of Păuliş Granites (Apuseni Mts., Romania). Acta Mineralogica-Petrographica 48:33-41

Pană DI, Heaman LM, Creaser RA, Erdmer P (2002) Pre-alpine crust in the Apuseni Mountains, Romania: insights from Sm-Nd and U-Pb data. J Geol 110:341-354. https://doi.org/10.1086/339536 
Paton C, Woodhead JD, Hellstrom JC, Hergt JM, Greig A, Maas R (2010) Improved laser ablation $\mathrm{U}-\mathrm{Pb}$ zircon geochronology through robust downhole fractionation correction. Geochem Geophys. https://doi.org/10.1029/2009gc002618

Paton C, Hellstroijm J, Paul B, Woodhead J, Hergt J (2011) Iolite: Freeware for the visualisation and processing of mass spectrometric data. J Anal Atom Spectrom 26(12):2508-2518. https://doi.org/10.1039/c1ja10172b

Paulick H, Breitkreuz C (2005) The Late Paleozoic felsic lava-dominated large igneous province in northeast Germany: volcanic facies analysis based on drill cores. Int J Earth Sci 94:834-850. https://doi.org/10.1007/s00531-005-0017-y

Pearce JA, Harris NBW, Tindle AG (1984) Trace element discrimination diagrams for the tectonic interpretation of granitic rocks. J Petrol 24(4):956-983. https://doi.org/10.1093/petrology/25.4.956

Petrus JA, Kamber BS (2012) VizualAge: A Novel Approach to Laser Ablation ICP-MS U-Pb Geochronology Data Reduction. Geostand Geoanal Res 36(3):247-270. https://doi.org/10.1111/j.1751-908x.2012.00158.x

Quane SL, Russell JK (2005) Ranking welding intensity in pyroclastic deposits. Bull Volcanol 67:129-143. https://doi.org/10.1007/s00445-004-0367-5

Raucsik B, Varga A, Mészáros E, Szemerédi M (2016) Very low-grade metamorphism of the Cisuralian basement formations (Korpád Sandstone, Gyürüfü Rhyolite) near Kelebia, Békés Unit, Hungary. Conference abstract, 8th Mid-European Clay Conference, Košice

Raucsik B, Szemerédi M, Mészáros E, Varga A, Dunkl I, Lukács R, Pál-Molnár E, Harangi Sz (2019) Kisfokú metamorfózis nyomai permi aljzati képződményekben (Kelebia, Békés-Codrui Egység). 10. Közettani és Geokémiai Vándorgyülés, Mátraháza, Saxa loquuntur - Köbe zárt történetek, p 74 (in Hungarian)

René M (2014) Rare-earth, yttrium and zirconium mobility associated with the uranium mineralisation at Okrouhlá Radouň, Bohemian Massif, Czech Republic. Eur J Mineral 27:57-70. https://doi.org/10.1127/ejm/2015/0027-2422

Repstock A, Breitkreuz C, Lapp M, Schulz B (2017) Voluminous and crystal-rich igneous rocks of the Permian Wurzen volcanic system, northern Saxony, Germany: physical volcanology and geochemical characterization. Int J Earth Sci 107:14851513. https://doi.org/10.1007/s00531-017-1554-X

Richnow J (1999) Eruptional and post-eruptional processes in rhyolite domes. PhD thesis, University of Canterbury, New Zeeland 
Rougvie JR, Sorensen SS (2002) Cathodluminescence record of K-metasomatism in ashflow tuffs: Grain-scale mechanisms and large-scale geochemical implications. Geology 30:307-310. https://doi.org/10.1130/00917613(2002)030<0307:crokmi>2.0.co;2

Rubin JN, Henry CD, Price JG (1993) The mobility of zirconium and other "immobile" elements during hydrothermal alteration. Chem Geol 110:29-47. https://doi.org/10.1016/0009-2541(93)90246-f

Rudnick RL, Fountain DM (1995) Nature and composition of the continental crust-a lower crustal perspective. Rev Geophys 33:267-309. https://doi.org/10.1029/95rg01302

Seghedi I (2010) Permian rhyolitic volcanism, changinig from subaqueous to subaerial in post-Variscan intra-continental Sirinia Basin (SW Romania-Eastern Europe). J Volcanol Geoth 201:312-324. https://doi.org/10.1016/j.jvolgeores.2010.07.015

Sláma J, Košler J, Condon DJ, Crowley JL, Gerdes A, Hanchar JM, Horstwood MSA, Morris GA, Nasdala L, Norberg N, Schaltegger U, Schoene B, Tubrett MN, Whitehouse MJ (2008) Plešovice zircon-A new natural reference material for U$\mathrm{Pb}$ dating and $\mathrm{Hf}$ isotopic microanalyses. Chem Geol 249(1-2):1-35. https://doi.org/10.1016/j.chemgeo.2007.11.005

Sliwinski J, Guillong M, Liebske Ch, Dunkl I, von Quadt A, Bachmann O (2017) Improved accuracy of LA-ICP-MS U-Pb ages in Cenozoic zircons by alpha dose correction. Chem Geol 472:8-21. https://doi.org/10.1016/j.chemgeo.2017.09.014

Słodczyk E, Pietranik A, Glynn S, Wiedenbeck M, Breitkreuz C, Dhuime B (2018) Contrasting sources of Late Paleozoic rhyolite magma in the Polish Lowlands: evidence from $\mathrm{U}-\mathrm{Pb}$ age and $\mathrm{Hf}$ and $\mathrm{O}$ isotope composition in zircon. Int $\mathrm{J}$ Earth Sci 107:2065. https://doi.org/10.1007/s00531-018-1588-8

Sommer CA, Fernandes de Lima E, Machado A, May Rossetti LM, Pierosan R (2013) Recognition and characterisation of high-grade ignimbrites from the neoproterozoic rhyolitic volcanism in southermost Brazil. J South Am Earth Sci 47:152-165. https://doi.org/10.1016/j.jsames.2013.07.010

Stevenson RJ, Briggs RM, Hodder APW (1994) Physical volcanology and emplacement history of the Ben Lomond rhyolite lava flow, Taupo Volcanic Centre, New Zealand. New Zealand Journal of Geology and Geophysics 37:345-358. https://doi.org/10.1080/00288306.1994.9514625 
Sun SS, McDonough WF (1989) Chemical and isotopic systematic of oceanic basalts implications for mantle compositions and processes. In: Saunders AD, Norry MJ (eds) Magmatism in ocean basins, 42. Geological Society London Special Publication, London, pp 312-345

Swanson SE, Naney MT, Westrich HR, Eichelberger JC (1989) Crystallization history of Obsidian Dome, Inyo Domes, California. Bull Volcanol 51:161-176. https://doi.org/10.1007/bf01067953

Szederkényi T (1962) Földtani jelentés a Ny-Mecseki (Gyürüfü) kvarcporfír földtani, kőzettani és radiológiai vizsgálatának eredményeiről. Report, Mecsekérc Ltd. (former Mecsek Ore Mining Company) (in Hungarian)

Szederkényi T, Haas J, Nagymarosy A, Hámor G (2013) Geology and History of Evolution of the Tisza Mega-unit. In: Haas J (ed) Geology of Hungary, pp 103148

Szemerédi M, Varga A, Lukács R, Pál-Molnár E (2016) Petrography of the Gyürüfü Rhyolite Formation, Western Mecsek Mts, Hungary. Földtani Közlöny 146(4):335354 (in Hungarian with English abstract)

Szemerédi M, Varga A, Lukács R, Pál-Molnár E (2017) Petrography of the Gyürüfü Rhyolite Formation, northern foreland of the Villány Mts, Hungary. Földtani Közlöny 147(4):357-382. https://doi.org/10.23928/foldt.kozl.2017.147.4.357 (in

\section{Hungarian with English abstract)}

Szemerédi M, Lukács R, Varga A, Seghedi I, Tatu M, Dunkl I, Pál-Molnár E, Harangi Sz (2018a) Permian volcanism in the Tisza Mega-unit: new petrographic, geochemical and geochronological results from Hungary and Romania. XXI International Congress of the CBGA, Salzburg, Austria, Abstract Book p 127

Szemerédi M, Varga A, Tatu M, Seghedi I, Dunkl I, Pál-Molnár E, Lukács R (2018b) Permian volcanism vs. Alpine nappe stacking: petrographic and geochemical observations for regional correlation of the Permian felsic volcanic rocks, Tisza Mega-unit (Hungary and Romania). EGU General Assembly 2018, Vienna, Austria, Geophysical Research Abstracts 20 (paper: EGU2018-1771)

Szemerédi M, Lukács R, Varga A, Dunkl I, Tatu M, Seghedi I, Pál-Molnár E, Harangi Sz (2019a) Could Permian felsic volcanic rocks and granites in the Tisza Mega-unit (Pannonian Basin) be in a plutonic-volcanic connection? Implications from zircon $\mathrm{U}-\mathrm{Pb}$ geochronology and whole-rock geochemistry. EGU General Assembly 
2019, Vienna, Austria, Geophysical Research Abstracts 21 (paper: EGU2019253)

Szemerédi M, Vígh Cs, Lukács R, Varga A, Seghedi I, Pál-Molnár E, Dunkl I, Fehér K, Harangi Sz (2019b) Magmás gránátok: kulcsszerep a Tisia permi Si-gazdag vulkanitjainak petrogenetikájában? 10. Közettani és Geokémiai Vándorgyülés, Mátraháza, Saxa loquuntur - Kőbe zárt történetek, pp 82-85 (in Hungarian)

Szemerédi M, Lukács R, Varga A, Dunkl I, Józsa S, Tatu M, Pál-Molnár E, Szepesi J, Guillong M, Szakmány Gy, Harangi Sz (2020a) Permian felsic volcanic rocks in the Pannonian Basin (Hungary): new petrographic, geochemical and geochronological results. Int J Earth Sci 109:101-125. https://doi.org/10.1007/s00531-019-01791-x

Szemerédi M, Varga A, Szepesi J, Pál-Molnár E, Lukács, R (2020b) Lavas or ignimbrites? Permian felsic volcanic rocks of the Tisza Mega-unit revisited: a petrographic study (SE Hungary). Central European Geology (in press)

Szemerédi M, Lukács R, Varga A, Dunkl I, Seghedi I, Tatu M, Pál-Molnár E, Szepesi J, Harangi Sz (2020c) Permian magmatism in the Carpathian-Pannonian region (Hungary and Romania): New geochemical and geochronological results. EGU General Assembly 2020 (paper: EGU2020-8405). https://doi.org/10.5194/egusphere-egu2020-8405

Szepesházy K (1967) Kőzettani adatok a battonyai gránit megismeréséhez. Annual report of the Geological Institute of Hungary from 1967, pp 227-266 (in Hungarian)

Szepesházy K (1979) A Tiszántúl és az Erdélyi Középhegység (Muntii Apuseni) nagyszerkezeti és rétegtani kapcsolatai. Általános Földtani Szemle 12:121-198 (in Hungarian)

Szepesi J (2007) Textural zonation and geochemistry of an acidic lava flow base, a case study of Sátor-Krakó range, Abaújszántó, Tokaj-mountains. Acta GGM Debrecina 2:115-132

Szepesi J, Kozák M (2008) A telkibányai Cser-hegy-Ó-Gönc riolit-perlit vonulat fáciesgenetikai és paleovulkáni rekontrukciója. Földtani Közlöny 138(1):61-83 (in Hungarian with English abstract)

Szepesi J (2009) A savanyú vulkanizmus fáciestani vizsgálata ÉK-Magyarországon. PhD Thesis, University of Debrecen, Debrecen (in Hungarian)

Szepesi J, Harangi Sz, Lukács R, Pál-Molnár E (2016) Facies analysis of a Late Miocene lava dome field in the Tokaj Mts. (Carpathian-Pannonian Region): Implication of a silicic caledera structure? In: Branca S, Groppelli G, Lucchi F, Sulpizio R (eds) 
Geological fieldwork in volcanic areas: mapping techniques and applications III. Workshop on Volcano Geology, July 3-10, 2016, Sicily. Abstract book pp 60-63

Szepesi J, Vona A, Kovács IJ, Fintor K, Buday T, Scarani A, Harangi Sz (2019) Cooling and hydration of the Carpathian obsidian, a differential scanning calorimetry (DSC), thermogravimetry (DTA) and infrared spectroscopy (FTIR) study. International Obsidian Conference, Sárospatak, Hungary, Abstract Book pp 64-65

T. Kovács G, Kurucz B (1984) A Dél-Alföld mezozoikumnál idősebb képződményei. Geological Institute of Hungary (special publication) (in Hungarian)

Varga A (2009) A dél-dunántúli paleozoos-alsó-triász sziliciklasztos kőzetek kőzettani és geokémiai vizsgálatának eredményei. PhD Thesis, Department of Petrology and Geochemistry, Eötvös Loránd University, Budapest (in Hungarian)

Varga A, Raucsik B (2009) Metaüledékes képződmények a Tiszai-egység aljzatában: a felső-paleozoikumi Túronyi Formáció (Szlavóniai-Drávai-terrénum). In: M. Tóth T (ed) Magmás és metamorf képződmények a Tiszai Egységben, GeoLitera, Szeged, pp 177-192 (in Hungarian)

Varga A, Raucsik B, Szakmány Gy (2012) On possible origin of background content of heavy metals and metaloids in the subsurface pennsylvanian Téseny Metasandstones, SW Hungary. Carpathian Journal of Earth and Environmental Sciences 7(3):211-218

Vermeesch P (2018) IsoplotR: a free and open toolbox for geochronology. Geosci Front 9:1479-1493. https://doi.org/10.1016/j.gsf.2018.04.001

Vincze J, G. Sólymos K, Ditrói Puskás Z, Kósa L (2011) Uranium-ore micro-veins in granite from the western part of the Mecsek Mts (Hungary). Földtani Közlöny 141(4):325-339 (in Hungarian with English abstract)

von Quadt A, Wotzlaw J-F, Buret Y, Large SJE, Peytcheva I, Trinquier A (2016) Highprecision zircon $\mathrm{U} / \mathrm{Pb}$ geochronology by ID-TIMS using new $1013 \mathrm{ohm}$ resistors. $\mathrm{J}$ Anal Atom Spectrom 31(3):658-665. https://doi.org/10.1039/c5ja00457h

Vozár J (1997) Rift-related volcanism in the Permian of the Western Carpathians. In: Grecula P, Hovorka D, Putiš M (eds) Geological evolution of the Western Carpathians. Mineralia Slovaca-Monograph, Bratislava, pp 225-234

Vozárová A, Šmelko M, Paderin I (2009) Permian single crystal U-Pb age of the Rožňava Formation volcanites (Southern Gemeric Unit, Western Carpathians, Slovakia). Geol Carpath 60(6):439-448. https://doi.org/10.2478/v10096-009-0032-1 
Vozárová A, Presnyakov S, Šarinová K, Šmelko M (2015) First evidence for PermianTriassic boundary volcanism in the Northern Gemericum: geochemistry and U$\mathrm{Pb}$ zircon geochronology. Geol Carpath 66:375-391. https://doi.org/10.1515/geoca-2015-0032

Vozárová A, Rodionov N, Vozár J, Lepekhina E, Šarinová K (2016) U-Pb zircon ages from Permian volcanic rocks and tonalite of the Northern Veporicum (Western Carpathians). Geol Carpath 61:221-237. https://doi.org/10.3190/jgeosci.215

Walker GPL (1973) Length of lava flows. Philosophical Transactions of the Royal Society of London A 274:107-118. https://doi.org/10.1098/rsta.1973.0030

Wiedenbeck M, Allé P, Corfu F, Griffin WL, Meier M, Oberli F, von Quadt A, Roddick JC, Spiegel W (1995) Three natural zircon standards for U-Th-Pb, Lu-Hf trace element and REE analyses. Geostandards Newsletter 19:1-23. https://doi.org/10.1111/j.1751-908x.1995.tb00147.x

Wilcock MAW, Cas RAF, Giordano G, Morelli C (2013) The eruption, pyroclastic flow behaviour, and caldera in-filling processes of the extremly large volume (> 1290 $\mathrm{km}^{3}$ ), intra- to extra-caldera, Permian Ora (Ignimbrite) Formation, Southern Alps, Italy. J Volcanol Geoth Res 265:102-126. https://doi.org/10.1016/j.jvolgeores.2013.08.012

Wilson M, Neumann ER, Davies GR, Timmerman MJ, Heermans M, Larsen BT (2004) Permo-Carboniferous Magmatism and Rifting in Europe. Geological Society Special Publication No. 223, London

Winchester JA, Floyd PA (1977) Geochemical discrimination of different magma series and their differentiation products using immobilile elements. Chem Geol 20:325343. https://doi.org/10.1016/0009-2541(77)90057-2 


\section{SUPPLEMENTARY FIGURES}
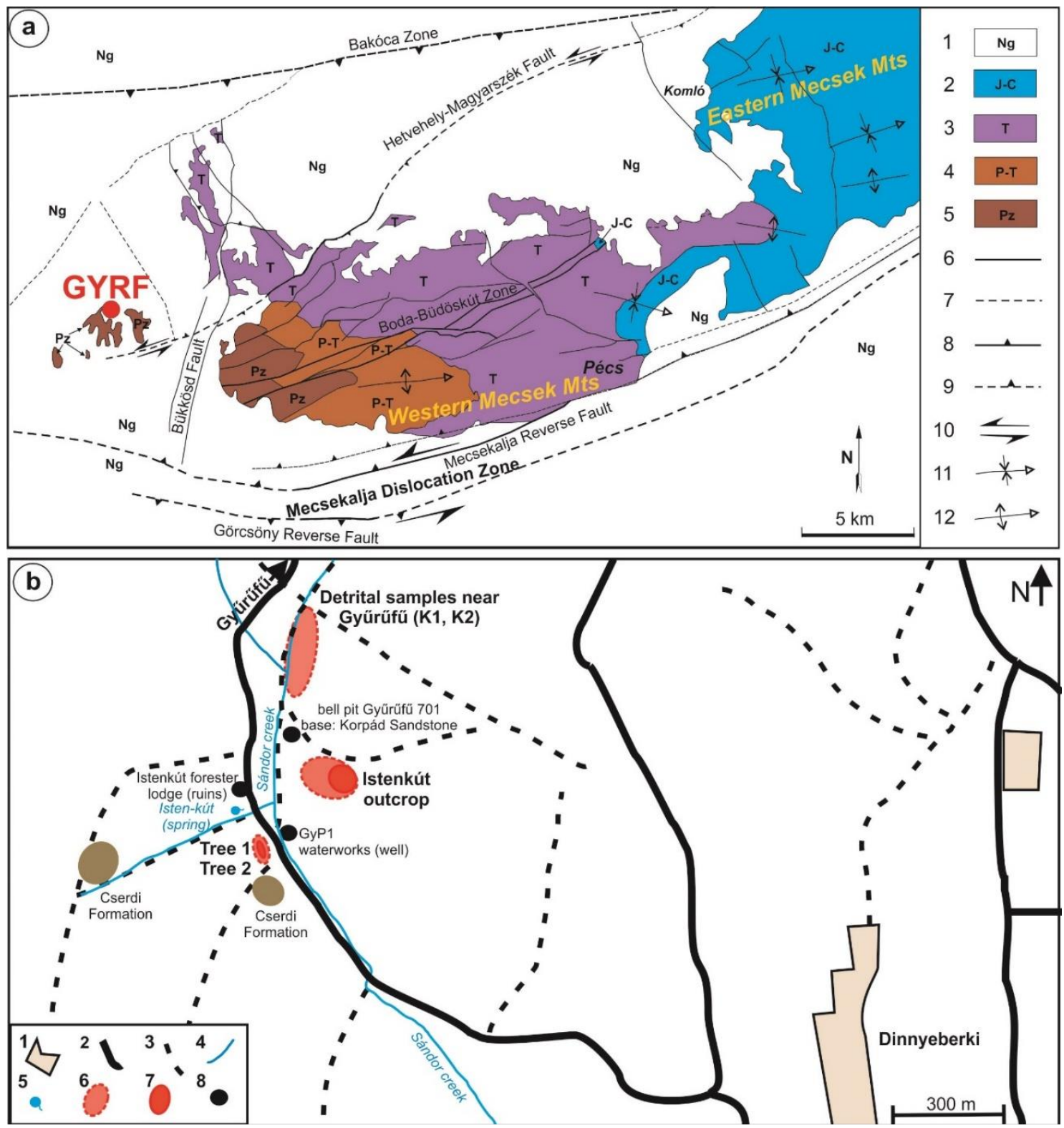

Supplementary Figure II.1 Structural framework and generalized geological map of the Western Mecsek Mts after Konrád and Sebe (2010), showing the locality where the observed Gyürüfü Rhyolite (GYRF) samples were collected (a) with the sketch of the sampling sites (b) in the area of the villages of Gyürüfü and Dinnyeberki

Legends: a 1 Neogene, 2 Jurassic and Cretaceous, 3 Triassic, 4 Upper Permian-Lower Triassic, 5

Palaeozoic in general, 6 observed fault, 7 compiled fault, 8 observed reverse fault, 9 compiled reverse fault, 10 strike-slip fault, 11 syncline, 12 anticline; b 1 settlement, 2 forest road, driveway, 3 hiking trail, valley (passable for pedestrians), 4 watercourse, 5 spring, 6 detrital outcrop, 7 outcrop in situ (bedrock), 8 artificial object 

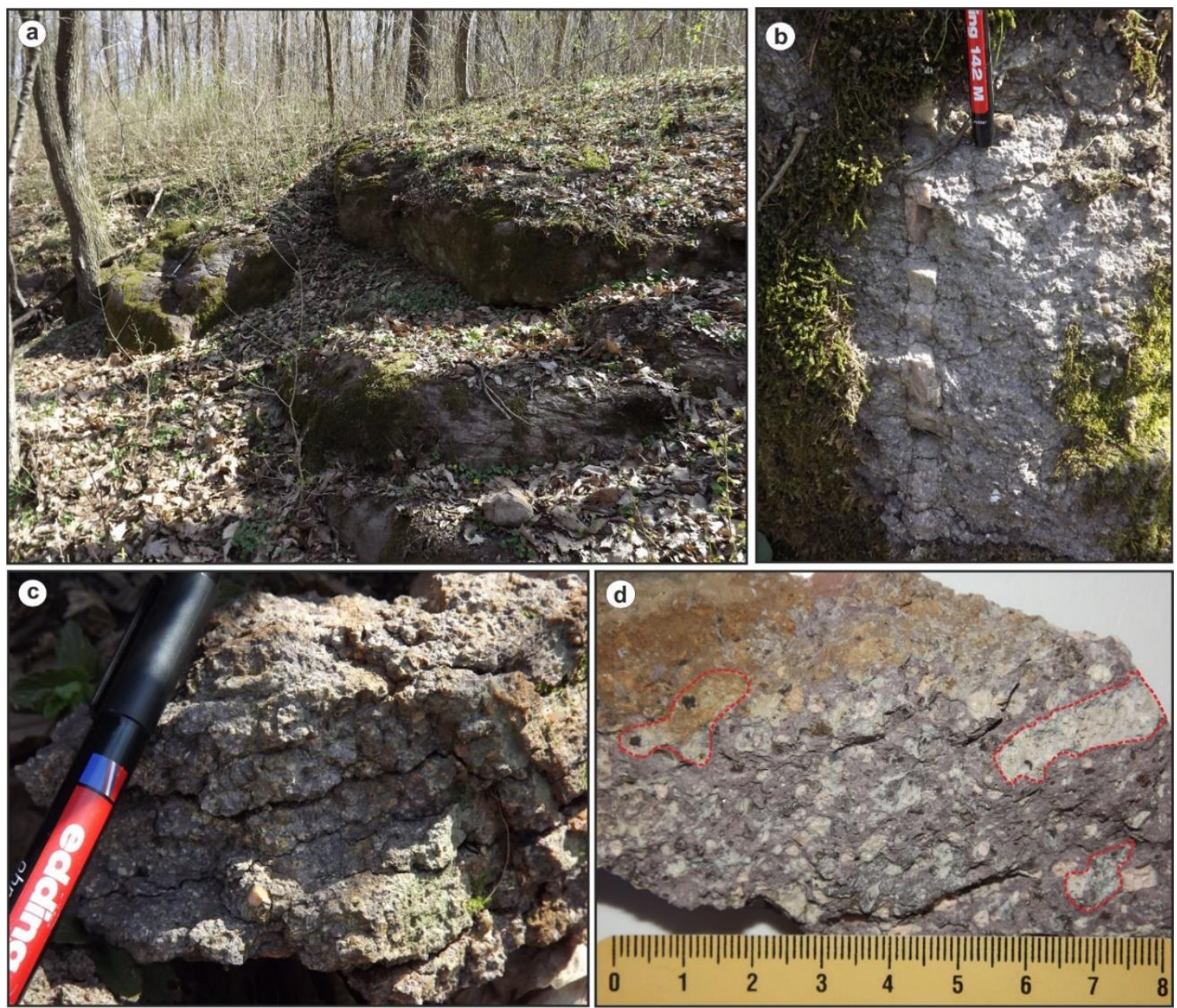

Supplementary Figure II.2 Gyürüfü, Istenkút sampling site (a) and the macroscopic appearance of the exposed rock samples $(\mathbf{b}-\mathbf{d})$. The altered pumices are delimited by red dashed lines 

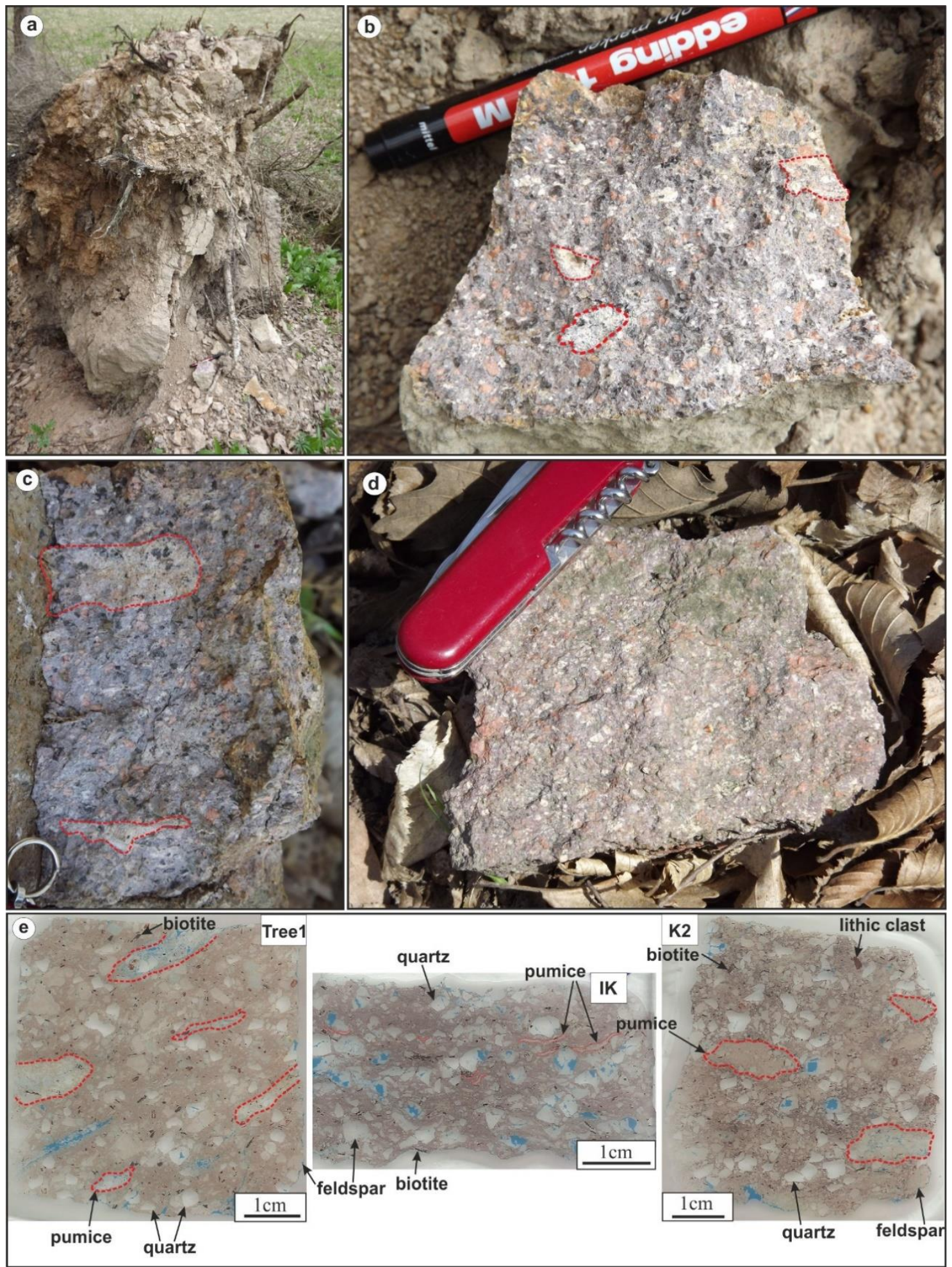

Supplementary Figure II.3 Rock samples of Gyürüfü Rhyolite from outcrops (both in situ and detrital material) situated along the road from Dinnyeberki to Gyürüfü (a-d) and the scanned images of three observed thin sections: Gyürüfü, Tree 1 (Tree 1), Gyürüfü, Istenkút outcrop $(I K)$ and a detrital sample near Gyürüfü $(K 2)$. a and b Gyürüfü Tree 1 sampling site; c Gyürüfü, Tree 2 sample; d Representative detrital sample near Gyürüfü. The altered pumices are delimited by red dashed lines 

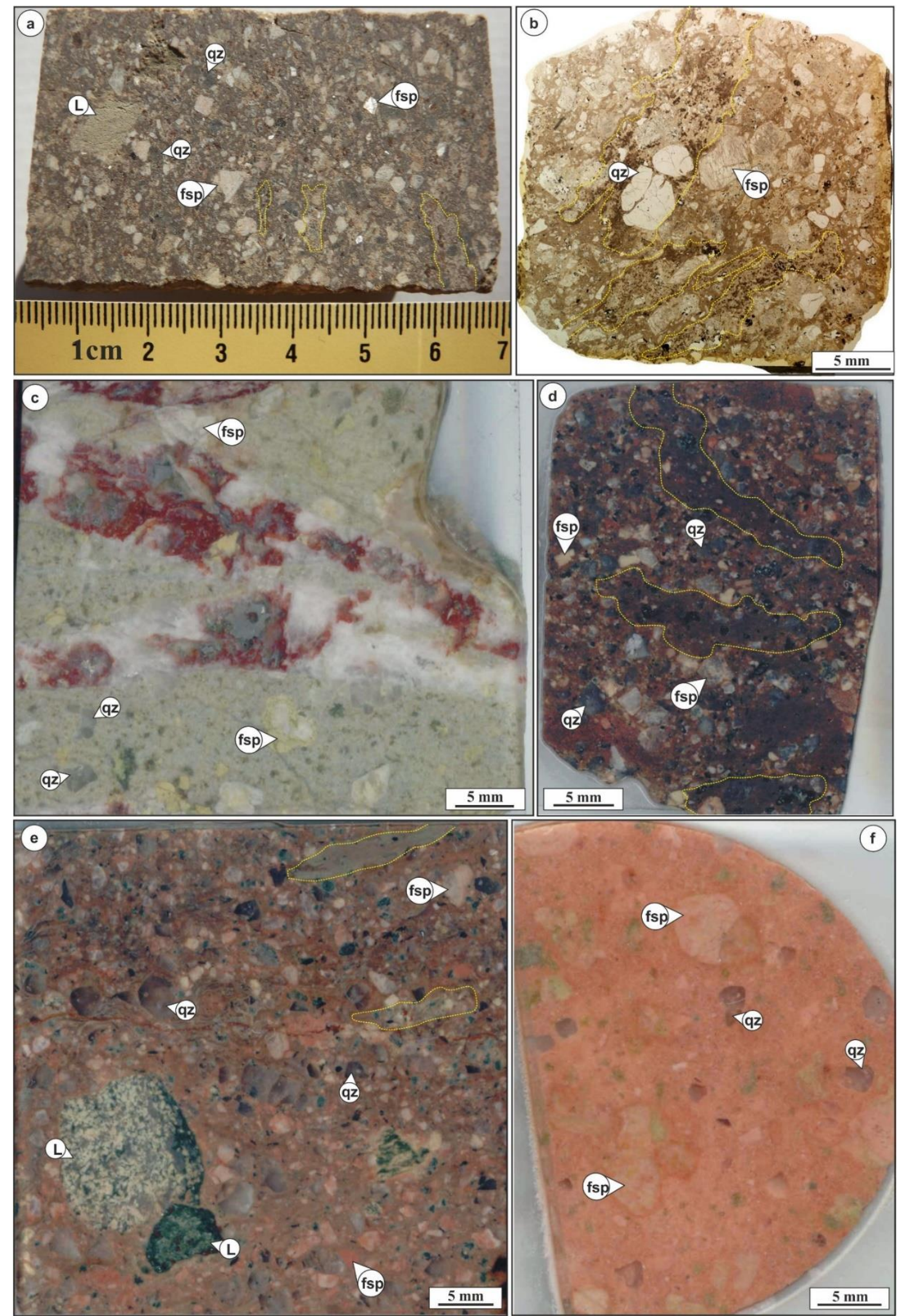

Supplementary Figure II.4 Macroscopic appearance of the Gyürüfü Rhyolite Formation at the northern foreland of Villány Mts. a Peterd-1 borehole (unknown depth); b Peterd-1 borehole (collection of the Mecsek Ore Mining Company, thin section No. 95); c Szava-1 borehole (depth: $444.8 \mathrm{~m}$ ); d Szalánta-3 borehole (depth: $381.0 \mathrm{~m}$ ); e Egerág-7 borehole (depth: $700 \mathrm{~m}$ ); f Egerág-7 borehole (depth: $1200 \mathrm{~m}$ ). c-f samples derive from the collection of the Eötvös Loránd University, Budapest (photo: Jakab 2005). $L$ lithic clast, $f s p$ feldspar, $q z$ quartz. Altered pumices are highlighted by yellow dashed lines 

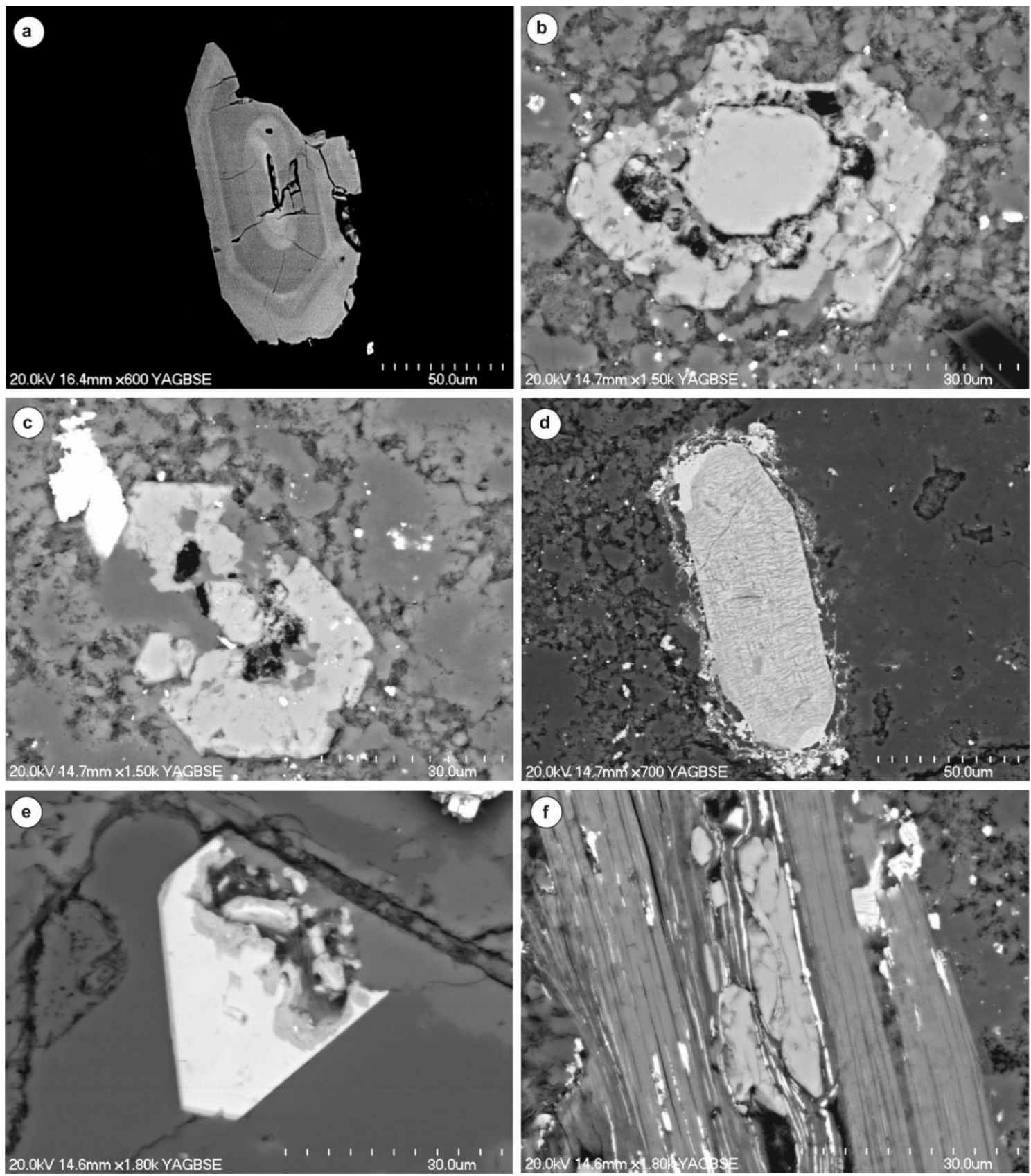

Supplementary Figure II.5 Accessory minerals in the samples of the outcrop of the Gyürüfü Rhyolite, Western Mecsek Mts (BSE images). a Euhedral, zoned zircon, broken at one of the pyramids; $\mathbf{b}$ and $\mathbf{c}$ Euhedral apatite crystals with rounded, resorbed cores; $\mathbf{d}$ Rounded opaque mineral (ilmenite according to the composition); e Euhedral, partially resorbed monazite; f Rutile inclusion in an opaque pseudomorph after biotite 

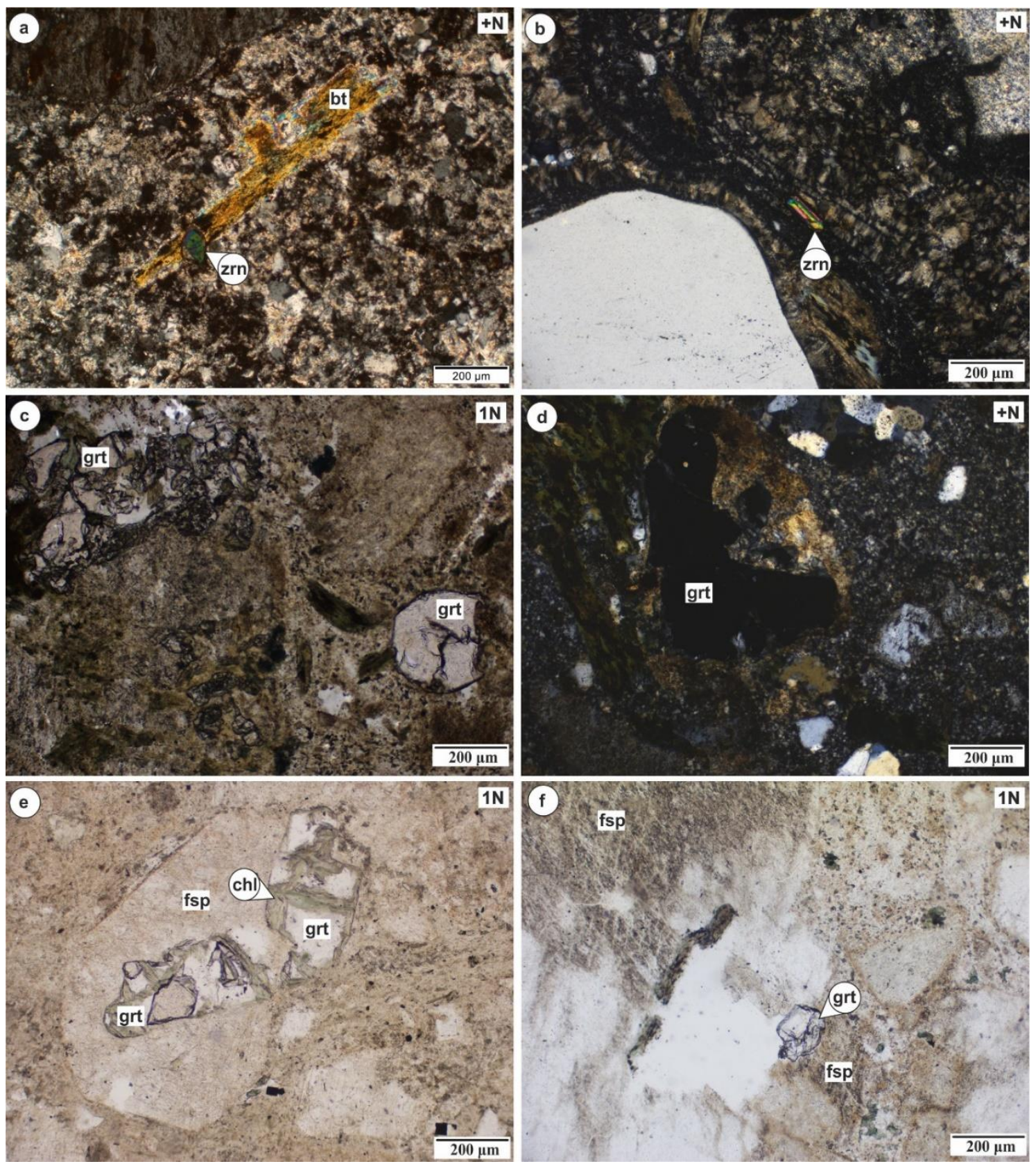

Supplementary Figure II.6 Accessory minerals in the samples of the Gyürüfü Rhyolite Formation, northern foreland of the Villány Mts. a Euhedral zircon as an inclusion in biotite, Vókány-2 borehole (unknown depth); b Euhedral, zoned zircon in the groundmass, Szalánta-3 borehole (depth: $333.3 \mathrm{~m}$ ); c Fragmented garnet crystals, Egerág-7 borehole (depth: $700 \mathrm{~m}$ ); d Subhedral garnet, Egerág-7 borehole (depth: $700 \mathrm{~m}$ ); e Subhedral, chloritized, fragmented garnet showing intergrowth with K-feldspar, Szalánta-3 borehole (depth: $387.5 \mathrm{~m}$ ); f Fragmented garnet in K-feldspar as inclusion, Szalánta-3 borehole (depth: $404.8 \mathrm{~m}$ ). bt biotite, $c h l$ chlorite, $f s p$ feldspar, grt garnet, $z r n$ zircon, $1 \mathrm{~N}$ plane polarized light, $+N$ crossed polars 

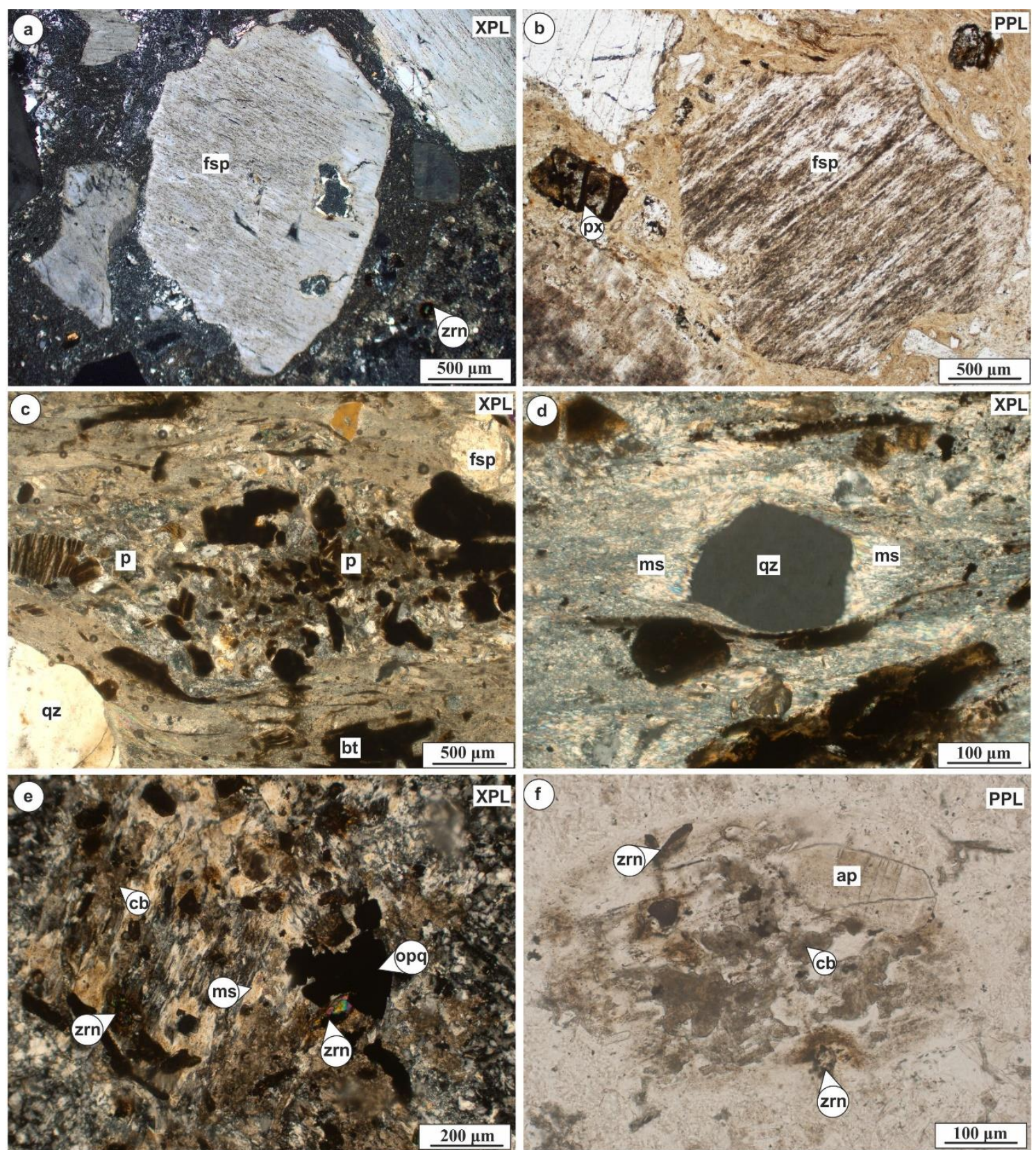

Supplementary Figure IV.1 Post-magmatic alterations of the Permian felsic volcanic rocks. a-b Sample Peterd-1, pyroclastite (northern foreland of the Villány Mts, borehole): pectinate K-feldspar phenocrysts; c-d Sample Kelebia-7, pyroclastite (Kelebia area, borehole, low-grade metamorphic rock): c Strongly altered, sericitized, parallel pumices, creating well-defined foliation; d Quartz phenocryst with symmetric $\mathrm{K}$-mica overgrowth in pressure shadow paralell with the foliation; e-f Sample Szava-1, lava (northern foreland of the Villány Mts, borehole): clots containing zircon, apatite, opaque minerals, carbonate and muscovite (hydrothermal mineralization). $a p$ apatite, $b t$ biotite, $c b$ carbonate, $f s p$ feldspar, $m s$ muscovite, $o p q$ opaque mineral, $p$ altered pumice, $p x$ pseudomorph after pyroxene, $q$ quartz, $z r n$ zircon, $P P L$ plane polarized light, $X P L$ crossed polars 


\section{SUPPLEMENTARY TABLES}

Supplementary Table II.1 Summarizing table of the available and studied samples (thin sections) of the Gyürüfü Rhyolite Formation at the northern foreland of the Villány Mts

\begin{tabular}{|c|c|c|c|}
\hline Borehole & Sample (No. in the collections) & Depth & Collection (origin) \\
\hline \multirow{3}{*}{ Bisse-1 } & perlitic quartz-porphyry (50) & $\begin{array}{l}\text { most possibly } \\
\geq 1025.0 \mathrm{~m}\end{array}$ & $\begin{array}{l}\text { Volcanites, etalon } \\
\text { collection (Mecsek Ore } \\
\text { Mining Company) }\end{array}$ \\
\hline & lower volcanite $(80)$ & $\sim 1100 \mathrm{~m}$ & $\begin{array}{l}\text { Mecsek Ore Mining } \\
\text { Company }\end{array}$ \\
\hline & $\begin{array}{l}\text { Bisse-1 borehole bottom, B/1 } \\
\text { sample ( } 49 \text { ) }\end{array}$ & $\sim 1100 \mathrm{~m}$ & $\begin{array}{l}\text { Volcanites, etalon } \\
\text { collection (Mecsek Ore } \\
\text { Mining Company) }\end{array}$ \\
\hline \multirow[t]{2}{*}{ Peterd-1 } & Peterd-1 borehole (95), $1057 \mathrm{~m}$ & & $\begin{array}{l}\text { Mecsek Ore Mining } \\
\text { Company }\end{array}$ \\
\hline & Via-13 & $1240.0 \mathrm{~m}$ & Eötvös Loránd University \\
\hline \multirow[t]{2}{*}{ Szava-1 } & $\begin{array}{l}\text { X-II-401120 (90) } \\
\text { X-II-401188 (87) } \\
\text { X-II-401191 (88) } \\
\text { X-II-401194 (91) } \\
\text { X-II-401195 (89) } \\
\text { Szava-1 (new) }\end{array}$ & $\begin{array}{l}353.5 \mathrm{~m} \\
469.1 \mathrm{~m} \\
472.7 \mathrm{~m} \\
476.8 \mathrm{~m} \\
477.8 \mathrm{~m} \\
\text { unknown }\end{array}$ & $\begin{array}{l}\text { Volcanites, etalon } \\
\text { collection (Mecsek Ore } \\
\text { Mining Company) } \\
\text { University of Szeged } \\
\text { (Mecsekérc Ltd.) }\end{array}$ \\
\hline & Via-15 & $444.8 \mathrm{~m}$ & Eötvös Loránd University \\
\hline \multirow{2}{*}{ Vókány-2 } & $\begin{array}{l}\text { V-2 } 400893(93) \\
\text { V-2 } 400871(94)\end{array}$ & $\begin{array}{l}774.8 \mathrm{~m} \\
1139.6 \mathrm{~m}\end{array}$ & $\begin{array}{l}\text { Mecsek Ore Mining } \\
\text { Company }\end{array}$ \\
\hline & $\begin{array}{l}\text { Via-14 } \\
\text { Vókány-2 (new) }\end{array}$ & $\begin{array}{l}1000.0 \mathrm{~m} \\
\text { unknown }\end{array}$ & $\begin{array}{l}\text { Eötvös Loránd University } \\
\text { University of Szeged } \\
\text { (Mecsekérc Ltd.) }\end{array}$ \\
\hline Egerág-7 & $\begin{array}{l}\text { Via-16 } \\
\text { Via-17 } \\
\text { Via-18 } \\
\text { Via-20 } \\
\end{array}$ & $\begin{array}{l}673.3 \mathrm{~m} \\
753.8 \mathrm{~m} \\
\sim 700 \mathrm{~m} \\
\sim 1200 \mathrm{~m} \\
\end{array}$ & Eötvös Loránd University \\
\hline Szalánta-3 & 16 thin sectioms & $299.0-548.7 \mathrm{~m}$ & $\begin{array}{l}\text { Mecsek Ore Mining } \\
\text { Company }\end{array}$ \\
\hline
\end{tabular}


Supplementary Table II.2 The major lithological groups (pyroclastites and lavas) of the Gyürüfü Rhyolite in the area of Southern Transdanubia

\begin{tabular}{|c|c|c|c|}
\hline $\begin{array}{l}\text { Area - } \\
\text { Lithology }\end{array}$ & $\begin{array}{l}\text { Western Mecsek Mts - } \\
\text { pyroclastite }\end{array}$ & $\begin{array}{l}\text { Northern foreland of the } \\
\text { Villány Mts - pyroclastite }\end{array}$ & $\begin{array}{l}\text { Northern foreland of the } \\
\text { Villány Mts - lava }\end{array}$ \\
\hline $\begin{array}{l}\text { Studied rock } \\
\text { samples }\end{array}$ & $\begin{array}{l}\text { Western Mecsek Mts, } \\
\text { outcrops (area } \\
\text { between the villages of } \\
\text { Gyürüfü and } \\
\text { Dinnyeberki) }\end{array}$ & $\begin{array}{l}\text { Peterd-1 borehole; } \\
\text { Vókány-2 (upper seq); } \\
\text { Egerág-7 (upper seq); } \\
\text { Szalánta-3 (upper seq); } \\
\text { Bisse-1 borehole (?) }\end{array}$ & $\begin{array}{l}\text { Szava-1 borehole; } \\
\text { Vókány-2 (lower seq); } \\
\text { Egerág-7 (lower seq); } \\
\text { Szalánta-3 (lower seq); } \\
\text { Bisse-1 borehole (?) }\end{array}$ \\
\hline $\begin{array}{l}\text { Top, base and } \\
\text { associated } \\
\text { formations }\end{array}$ & $\begin{array}{l}\text { base: Korpád } \\
\text { Sandstone (Lower } \\
\text { Permian); } \\
\text { top: Cserdi Formation } \\
\text { (Middle Permian) and } \\
\text { Pleistocene or } \\
\text { Pannonian formations }\end{array}$ & $\begin{array}{l}\text { base: Korpád Sandstone } \\
\text { (Lower Permian; not } \\
\text { penetrated in the Bisse-1 } \\
\text { borehole) and lavas, } \\
\text { underlying the } \\
\text { pyroclastites in boreholes } \\
\text { Vókány-2, Egerág-7 and } \\
\text { Szalánta-3; } \\
\text { top: Jakabhegy } \\
\text { Sandstone (Lower } \\
\text { Triassic) and Pannonian } \\
\text { sediments }\end{array}$ & $\begin{array}{l}\text { base: Korpád Sandstone } \\
\text { (Lower Permian; not } \\
\text { penetrated in the Bisse-1 } \\
\text { borehole); } \\
\text { top: Jakabhegy Sandstone } \\
\text { (Bisse-1), tectonic (Szava- } \\
\text { 1) and pyroclastic rocks } \\
\text { covering lavas in boreholes } \\
\text { Vókány-2, Egerág-7 and } \\
\text { Szalánta-3) }\end{array}$ \\
\hline $\begin{array}{l}\text { Petrographic } \\
\text { observations } \\
\text { and } \\
\text { interpretations }\end{array}$ & $\begin{array}{l}\text { eutaxitic, welded and } \\
\text { non-welded, crystal- } \\
\text { rich, pumice-bearing } \\
\text { lapilli tuffs } \\
\text { (igimbrites); } \\
\text { flattened, deformed } \\
\text { pumices having } \\
\text { axiolitic rims and } \\
\text { spherulites and } \\
\text { crystals inside; } \\
\text { lithic clasts } \\
\text { (sedimentary, Korpád } \\
\text { Sandstone) }\end{array}$ & $\begin{array}{l}\text { eutaxitic, welded, } \\
\text { pumice-bearing lapilli } \\
\text { tuffs (ignimbrites; } \\
\text { Peterd-1, Egerág-7 and } \\
\text { Szalánta-3 boreholes) or } \\
\text { not oriented, relict, } \\
\text { vitroclastic rocks } \\
\text { (Vókány-2 borehole); } \\
\text { axiolitic pumices having } \\
\text { spherulites and crystals } \\
\text { inside, excepting the } \\
\text { Vókány-2 borehole } \\
\text { (replaced by mosaic } \\
\text { quartz); } \\
\text { lithic clasts (Peterd-1 and } \\
\text { Vókány-2 boreholes, } \\
\text { sedimentary) }\end{array}$ & $\begin{array}{l}\text { porphyric } \\
\text { microholocrystalline } \\
\text { (Szava-1, locally } \\
\text { granophyric and Egerág-7 } \\
\text { boreholes); } \\
\text { felsitic-microfelsitic } \\
\text { (Vókány-2, spherulitic, too } \\
\text { and Szalánta-3 boreholes); } \\
\text { perlitic texture (with the } \\
\text { remnants of pumices, } \\
\text { Bisse-1 borehole); } \\
\text { distinguishing between } \\
\text { subvolcanic rocks and lavas } \\
\text { is not possible by } \\
\text { petrographic observations } \\
\text { (intense fragmentation, } \\
\text { alterations, few samples) }\end{array}$ \\
\hline Phenocrystals & $\begin{array}{l}\text { subhedral, resorbed } \\
\text { quartz, having fluid } \\
\text { inclusion assemblages } \\
\text { inside; } \\
\text { mosaic feldspar } \\
\text { crystals (K-feldspar } \\
\text { and plagioclase, barely } \\
\text { distinguishable); } \\
\text { hematitized biotite } \\
\text { pseudomorphs after } \\
\text { pyroxene }\end{array}$ & $\begin{array}{l}\text { subhedral, resorbed } \\
\text { quartz, having fluid } \\
\text { inclusion assemblages } \\
\text { inside; } \\
\text { iridescent, pectinate } \\
\text { feldspar (Peterd-1); } \\
\text { dominance of K-feldspar, } \\
\text { intense alterations; } \\
\text { faded, chloritized or } \\
\text { hematitized biotite; } \\
\text { pseudomorphs after } \\
\text { pyroxene (Peterd-1) }\end{array}$ & $\begin{array}{l}\text { subhedral, resorbed quartz, } \\
\text { often having fringy rims } \\
\text { and fluid inclusion } \\
\text { assemblages inside; } \\
\text { altered feldspar cyrstals; } \\
\text { Egerág-7 and Szalánta-3 } \\
\text { boreholes: dominance of } \\
\text { plagioclase, while in the } \\
\text { other samples K-feldspar is } \\
\text { the dominant; fringy rims in } \\
\text { Egerág-7 and Szalánta-3; } \\
\text { faded, chloritized or } \\
\text { hematitized biotite }\end{array}$ \\
\hline $\begin{array}{l}\text { Accessory } \\
\text { minerals }\end{array}$ & $\begin{array}{l}\text { zircon, apatite, } \\
\text { monazite, rutile, } \\
\text { xenotime, ilmenite } \\
\end{array}$ & $\begin{array}{l}\text { zircon, apatite (Peterd-1, } \\
\text { Szalánta-3), garnet } \\
\text { (Egerág-7, Szalánta-3) }\end{array}$ & zircon and apatite (Szava-1) \\
\hline $\begin{array}{l}\text { Composition } \\
\text { according to the } \\
\text { petrography }\end{array}$ & rhyolitic & rhyolitic & $\begin{array}{l}\text { rhyolitic (Bisse-1, Szava-1 } \\
\text { and Vókány-2), } \\
\text { dacitic (Egerág-7), } \\
\text { rhyodacitic/dacitic } \\
\text { (Szalánta-3) }\end{array}$ \\
\hline
\end{tabular}


Supplementary Table IV.1 Major and trace elements data of the Permian volcanic rocks of the Tisza Mega-unit, Hungary (Western Mecsek Mts, northern foreland of the Villány Mts). $p$ pyroclastic rocks, $l$ lavas, $\mathrm{Eu} / \mathrm{Eu}^{*}=\left[\mathrm{Eu}_{\mathrm{N}} /\left(\mathrm{Sm}_{\mathrm{N}} \times \mathrm{Gd}_{\mathrm{N}}\right)^{1 / 2}\right], N=$ chondrite normalized values. Chondrite data come from Sun and McDonough (1989)

\begin{tabular}{|c|c|c|c|c|c|c|c|c|c|c|}
\hline \multirow{2}{*}{$\begin{array}{l}\begin{array}{l}\text { Subsurface } \\
\text { region }\end{array} \\
\text { Borehole }\end{array}$} & & \multicolumn{4}{|c|}{ Western Mecsek Mts } & \multicolumn{5}{|c|}{ Northern foreland of the Villány Mts } \\
\hline & & $\begin{array}{l}\text { GYR } \\
\text { FP }\end{array}$ & 9018 & XV & $\begin{array}{l}\text { XV } \\
\text { (grey) }\end{array}$ & $\begin{array}{l}\text { Egerág- } \\
7\end{array}$ & $\begin{array}{l}\text { Peterd- } \\
1\end{array}$ & $\begin{array}{l}\text { Szalánta- } \\
3\end{array}$ & $\begin{array}{l}\text { Szava- } \\
1 \\
\end{array}$ & $\begin{array}{l}\text { Vókány- } \\
2\end{array}$ \\
\hline $\begin{array}{l}\text { Rock type } \\
(\mathrm{p} / \mathrm{l})\end{array}$ & & $\mathrm{p}$ & $\mathrm{p}$ & $\mathrm{p}$ & $\mathrm{p}$ & $\mathrm{p}$ & $\mathrm{p}$ & $\mathrm{p}$ & 1 & 1 \\
\hline $\mathrm{SiO}_{2}$ & & 74.46 & 74.72 & 70.95 & 73.83 & 73.27 & 69.05 & 71.38 & 74.12 & 75.63 \\
\hline $\mathrm{TiO}_{2}$ & & 0.17 & 0.18 & 0.31 & 0.18 & 0.24 & 0.30 & 0.29 & 0.18 & 0.05 \\
\hline $\mathrm{Al}_{2} \mathrm{O}_{3}$ & & 12.80 & 12.33 & 14.70 & 14.27 & 13.24 & 13.91 & 14.06 & 12.58 & 13.02 \\
\hline $\mathrm{Fe}_{2} \mathrm{O}_{3} \mathrm{t}$ & & 2.72 & 1.84 & 2.37 & 1.58 & 1.88 & 2.83 & 2.42 & 3.20 & 2.47 \\
\hline $\mathrm{MnO}$ & & 0.02 & 0.03 & 0.03 & 0.01 & 0.03 & 0.12 & 0.05 & 0.14 & 0.03 \\
\hline $\mathrm{MgO}$ & $\mathrm{wt} \%$ & 0.54 & 0.71 & 0.72 & 1.14 & 0.36 & 0.49 & 0.71 & 0.28 & 0.17 \\
\hline $\mathrm{CaO}$ & & 0.16 & 1.08 & 0.24 & 0.22 & 0.33 & 0.24 & 0.36 & 0.18 & 0.29 \\
\hline $\mathrm{Na}_{2} \mathrm{O}$ & & 1.62 & 1.90 & 2.74 & 4.22 & 2.35 & 0.93 & 2.54 & 0.11 & 0.12 \\
\hline $\mathrm{K}_{2} \mathrm{O}$ & & 5.42 & 4.05 & 6.08 & 2.07 & 5.88 & 8.39 & 5.81 & 6.19 & 5.55 \\
\hline $\mathrm{P}_{2} \mathrm{O}_{5}$ & & 0.09 & 0.09 & 0.13 & 0.13 & 0.11 & 0.14 & 0.12 & 0.11 & 0.22 \\
\hline LOI & & 1.90 & 2.70 & 1.35 & 1.90 & 2.10 & 3.40 & 2.00 & 2.80 & 2.40 \\
\hline sum & & 99.90 & 99.64 & 99.61 & 99.55 & 99.77 & 99.81 & 99.75 & 99.89 & 99.95 \\
\hline $\mathrm{Ba}$ & & 396 & 408 & 361 & 51 & 295 & 580 & 390 & 313 & 69 \\
\hline $\mathrm{Sc}$ & & 4 & 4 & 6 & 4 & 5 & 6 & 6 & 4 & 3 \\
\hline $\mathrm{Rb}$ & & 139 & 135 & 215 & 122 & 226 & 313 & 230 & 229 & 447 \\
\hline $\mathrm{Cs}$ & & 5 & 6 & 6 & 5 & 6 & 14 & 6 & 15 & 26 \\
\hline $\mathrm{Y}$ & & 44 & 44 & 51 & 40 & 53 & 47 & 46 & 47 & 12 \\
\hline $\mathrm{La}$ & & 21.30 & 25.50 & 39.65 & 19.80 & 29.95 & 41.00 & 31.10 & 20.50 & 2.20 \\
\hline $\mathrm{Ce}$ & & 49.70 & 54.90 & 89.60 & 44.90 & 67.65 & 93.50 & 71.10 & 46.80 & 7.20 \\
\hline $\operatorname{Pr}$ & & 6.02 & 6.68 & 10.46 & 5.39 & 7.96 & 10.75 & 8.26 & 5.64 & 0.92 \\
\hline $\mathrm{Nd}$ & & 21.90 & 25.40 & 42.35 & 23.20 & 33.20 & 45.30 & 35.60 & 21.10 & 3.40 \\
\hline $\mathrm{Sm}$ & & 5.08 & 6.40 & 9.20 & 5.40 & 7.35 & 8.90 & 7.40 & 5.43 & 1.50 \\
\hline $\mathrm{Eu}$ & & 0.32 & 0.31 & 0.60 & 0.27 & 0.48 & 0.75 & 0.60 & 0.30 & $<0.02$ \\
\hline $\mathrm{Gd}$ & & 5.85 & 6.23 & 8.72 & 5.52 & 7.75 & 8.90 & 7.36 & 6.19 & 1.94 \\
\hline $\mathrm{Tb}$ & & 1.12 & 1.25 & 1.42 & 1.17 & 1.34 & 1.43 & 1.33 & 1.17 & 0.49 \\
\hline Dy & & 7.02 & 7.31 & 8.38 & 6.19 & 8.03 & 8.48 & 7.70 & 7.65 & 2.65 \\
\hline Ho & & 1.50 & 1.37 & 1.69 & 1.26 & 1.48 & 1.57 & 1.48 & 1.61 & 0.35 \\
\hline $\mathrm{Er}$ & ppm & 4.46 & 4.22 & 4.75 & 3.65 & 4.51 & 4.61 & 4.49 & 4.67 & 0.73 \\
\hline $\mathrm{Yb}$ & & 4.15 & 3.93 & 4.69 & 3.59 & 4.43 & 4.32 & 4.25 & 4.34 & 0.48 \\
\hline $\mathrm{Lu}$ & & 0.61 & 0.58 & 0.70 & 0.53 & 0.64 & 0.63 & 0.58 & 0.61 & 0.05 \\
\hline $\mathrm{Th}$ & & 16 & 15 & 22 & 16 & 19 & 23 & 20 & 17 & 6 \\
\hline $\mathrm{U}$ & & 2 & 4 & 5 & 6 & 6 & 3 & 6 & 7 & 4 \\
\hline $\mathrm{V}$ & & $<8$ & 9 & 10 & 8 & 14 & 18 & 22 & 8 & $<8$ \\
\hline Co & & 3 & 3 & 4 & 2 & 3 & 7 & 4 & 1 & 0 \\
\hline $\mathrm{Ni}$ & & $<20$ & 20 & 44 & 35 & 27 & 29 & 27 & $<20$ & $<20$ \\
\hline $\mathrm{Zr}$ & & 129 & 138 & 237 & 124 & 163 & 262 & 198 & 136 & 36 \\
\hline $\mathrm{Nb}$ & & 10 & 11 & 12 & 11 & 11 & 11 & 12 & 12 & 21 \\
\hline Hf & & 4 & 5 & 8 & 5 & 6 & 8 & 6 & 4 & 2 \\
\hline $\mathrm{Ta}$ & & 1 & 1 & 1 & 1 & 1 & 1 & 1 & 1 & 3 \\
\hline $\mathrm{Ga}$ & & 17 & 19 & 21 & 20 & 20 & 20 & 22 & 18 & 25 \\
\hline $\mathrm{Be}$ & & 3 & 5 & 3 & 4 & 3 & 4 & 3 & 2 & 5 \\
\hline $\mathrm{Sn}$ & & 6 & 7 & 6 & 8 & 7 & 5 & 7 & 5 & 24 \\
\hline $\mathrm{Sr}$ & & 35 & 51 & 47 & 143 & 56 & 94 & 73 & 73 & 15 \\
\hline W & & 3 & 3 & 3 & 1 & 3 & 6 & 3 & 2 & 9 \\
\hline $\mathrm{Tm}$ & & 0.65 & 0.68 & 0.71 & 0.58 & 0.68 & 0.70 & 0.63 & 0.69 & 0.10 \\
\hline$(\mathrm{La} / \mathrm{Yb})_{\mathrm{N}}$ & & 3.7 & 4.7 & 6.1 & 4.0 & 4.9 & 6.8 & 5.3 & 3.4 & 3.3 \\
\hline $\mathrm{Eu} / \mathrm{Eu}^{*}$ & & 0.2 & 0.2 & 0.2 & 0.2 & 0.2 & 0.3 & 0.3 & 0.2 & 0.0 \\
\hline
\end{tabular}


Supplementary Table IV.2 Major and trace elements data of the Permian volcanic rocks of the Tisza Mega-unit, Hungary (Máriakéménd-Báta Basement Range, Battonya-Pusztaföldvár Basement Ridge, Kelebia area). Bat Battonya; $p$ pyroclastic rocks, $l$ lavas, $\mathrm{Eu} / \mathrm{Eu}^{*}=\left[\mathrm{Eu}_{N} /\left(\mathrm{Sm}_{\mathrm{N}} \times \mathrm{Gd}_{\mathrm{N}}\right)^{1 / 2}\right], N=$ chondrite normalized values. Chondrite data come from Sun and McDonough (1989)

\begin{tabular}{|c|c|c|c|c|c|c|c|c|c|c|}
\hline \multirow{2}{*}{$\begin{array}{l}\text { Subsurface } \\
\text { region }\end{array}$} & & \multicolumn{3}{|c|}{$\begin{array}{l}\text { Máriakéménd-Báta Basement } \\
\text { Range }\end{array}$} & \multicolumn{5}{|c|}{ Battonya-Pusztaföldvár Basement Ridge } & \multirow{2}{*}{$\begin{array}{l}\text { Kelebia } \\
\text { area } \\
\text { Kel-7 }\end{array}$} \\
\hline & & $\begin{array}{l}\text { Báta- } \\
3\end{array}$ & $\begin{array}{l}\text { Mária- } \\
\text { kéménd } \\
-3\end{array}$ & $\begin{array}{l}\text { Somberek- } \\
1\end{array}$ & $\begin{array}{l}\text { BATR/ } \\
2\end{array}$ & Bat-32 & Bat-52 & Bat-52 & $\begin{array}{l}\text { Bat- } \\
56\end{array}$ & \\
\hline $\begin{array}{l}\text { Rock type } \\
(\mathrm{p} / \mathrm{l})\end{array}$ & & $\mathrm{p}$ & $\mathrm{p}$ & $\mathrm{p}$ & $\mathrm{p}$ & $\mathrm{p}$ & $\mathrm{p}$ & $\mathrm{p}$ & $\mathrm{p}$ & $\mathrm{p}$ \\
\hline $\mathrm{SiO}_{2}$ & \multirow{12}{*}{ wt $\%$} & 71.55 & 73.77 & 74.73 & 74.27 & 74.75 & 73.84 & 72.67 & 76.51 & 60.65 \\
\hline $\mathrm{TiO}_{2}$ & & 0.20 & 0.07 & 0.16 & 0.20 & 0.16 & 0.15 & 0.15 & 0.09 & 0.85 \\
\hline $\mathrm{Al}_{2} \mathrm{O}_{3}$ & & 13.7 & 13.48 & 12.77 & 13.02 & 13.10 & 12.82 & 12.67 & 12.17 & 18.54 \\
\hline $\mathrm{Fe}_{2} \mathrm{O}_{3} \mathrm{t}$ & & 2.34 & 2.41 & 2.36 & 3.35 & 2.43 & 2.85 & 3.30 & 2.28 & 4.27 \\
\hline $\mathrm{MnO}$ & & 0.01 & 0.02 & 0.02 & 0.02 & $<0.01$ & 0.02 & 0.05 & 0.02 & 0.03 \\
\hline $\mathrm{MgO}$ & & 0.41 & 0.27 & 2.18 & 0.65 & 0.27 & 0.30 & 0.42 & 0.13 & 2.02 \\
\hline $\mathrm{CaO}$ & & 0.72 & 0.19 & 0.19 & 0.04 & 0.02 & 0.07 & 0.18 & 0.21 & 0.34 \\
\hline $\mathrm{Na}_{2} \mathrm{O}$ & & 0.33 & 1.43 & 1.74 & 0.14 & 0.13 & 2.68 & 2.21 & 2.81 & 1.54 \\
\hline $\mathrm{K}_{2} \mathrm{O}$ & & 8.35 & 6.80 & 3.10 & 5.94 & 7.29 & 6.05 & 6.69 & 4.82 & 8.82 \\
\hline $\mathrm{P}_{2} \mathrm{O}_{5}$ & & 0.07 & 0.17 & 0.11 & 0.05 & 0.02 & 0.02 & 0.01 & 0.01 & 0.25 \\
\hline LOI & & 2.20 & 1.40 & 2.60 & 2.20 & 1.70 & 1.10 & 1.50 & 0.90 & 2.40 \\
\hline sum & & 99.89 & 100.01 & 99.96 & 99.88 & 99.87 & 99.90 & 99.85 & 99.95 & 99.82 \\
\hline $\mathrm{Ba}$ & \multirow{31}{*}{ ppm } & 395 & 77 & 62 & 175 & 708 & 84 & 94 & 59 & 603 \\
\hline $\mathrm{Sc}$ & & 4 & 3 & 3 & 7 & 2 & 2 & 2 & 2 & 14 \\
\hline $\mathrm{Rb}$ & & 211 & 463 & 163 & 217 & 212 & 165 & 168 & 186 & 376 \\
\hline Cs & & 4 & 12 & 12 & 10 & 11 & 3 & 3 & 4 & 11 \\
\hline $\mathrm{Y}$ & & 49 & 16 & 32 & 49 & 37 & 58 & 59 & 68 & 42 \\
\hline $\mathrm{La}$ & & 18.70 & 5.10 & 16.40 & 40.10 & 53.90 & 75.80 & 75.80 & 45.70 & 58.90 \\
\hline $\mathrm{Ce}$ & & 39.50 & 13.40 & 39.30 & 86.60 & 105.80 & 154.90 & 158.70 & 99.10 & 120.30 \\
\hline $\operatorname{Pr}$ & & 4.59 & 1.55 & 4.71 & 11.08 & 14.05 & 18.30 & 18.33 & 12.66 & 13.68 \\
\hline $\mathrm{Nd}$ & & 19.00 & 5.10 & 17.70 & 44.10 & 54.10 & 68.10 & 69.40 & 49.10 & 53.60 \\
\hline $\mathrm{Sm}$ & & 4.40 & 1.87 & 4.48 & 9.71 & 10.18 & 12.87 & 13.14 & 11.79 & 10.76 \\
\hline $\mathrm{Eu}$ & & 0.26 & 0.03 & 0.24 & 0.40 & 0.33 & 0.41 & 0.42 & 0.07 & 1.38 \\
\hline $\mathrm{Gd}$ & & 6.80 & 2.30 & 5.09 & 8.81 & 8.26 & 11.70 & 12.31 & 12.00 & 9.45 \\
\hline $\mathrm{Tb}$ & & 1.23 & 0.52 & 0.94 & 1.40 & 1.24 & 1.79 & 1.94 & 1.99 & 1.39 \\
\hline Dy & & 8.02 & 3.09 & 5.83 & 8.41 & 7.44 & 10.75 & 11.33 & 12.09 & 8.26 \\
\hline Ho & & 1.51 & 0.51 & 1.12 & 1.77 & 1.40 & 2.13 & 2.27 & 2.39 & 1.54 \\
\hline Er & & 4.58 & 1.22 & 3.22 & 5.24 & 4.20 & 6.33 & 6.51 & 6.98 & 4.38 \\
\hline $\mathrm{Yb}$ & & 3.88 & 1.03 & 2.94 & 4.81 & 4.44 & 5.92 & 5.94 & 6.66 & 4.19 \\
\hline $\mathrm{Lu}$ & & 0.61 & 0.12 & 0.43 & 0.73 & 0.68 & 0.90 & 0.88 & 0.97 & 0.61 \\
\hline Th & & 15 & 9 & 14 & 18 & 18 & 17 & 17 & 19 & 24 \\
\hline $\mathrm{U}$ & & 3 & 3 & 7 & 4 & 2 & 7 & 3 & 8 & 6 \\
\hline $\mathrm{V}$ & & 10 & $<8$ & 18 & 15 & $<8$ & $<8$ & 10 & $<8$ & 52 \\
\hline $\mathrm{Co}$ & & 2 & 1 & 6 & 3 & 0 & 1 & 1 & 0 & 78 \\
\hline $\mathrm{Ni}$ & & 20 & $<20$ & 25 & $<20$ & $<20$ & $<20$ & $<20$ & $<20$ & $<20$ \\
\hline $\mathrm{Zr}$ & & 143 & 47 & 107 & 169 & 306 & 299 & 300 & 147 & 338 \\
\hline $\mathrm{Nb}$ & & 12 & 20 & 12 & 17 & 22 & 21 & 20 & 21 & 20 \\
\hline Hf & & 4 & 2 & 4 & 6 & 10 & 9 & 9 & 7 & 9 \\
\hline $\mathrm{Ta}$ & & 1 & 3 & 1 & 2 & 1 & 1 & 1 & 2 & 2 \\
\hline $\mathrm{Ga}$ & & 22 & 23 & 17 & 17 & 18 & 21 & 20 & 21 & 27 \\
\hline $\mathrm{Be}$ & & 3 & 6 & 6 & 4 & 3 & 4 & 2 & 2 & 4 \\
\hline $\mathrm{Sn}$ & & 8 & 23 & 9 & 9 & 5 & 5 & 5 & 9 & 9 \\
\hline $\mathrm{Sr}$ & & 61 & 15 & 34 & 64 & 15 & 22 & 29 & 13 & 30 \\
\hline
\end{tabular}


Supplementary Table IV.3 Major and trace elements data of the Permian volcanic rocks of the ALCAPA Mega-unit (Central Transdanubia, Hungary). $d$ dykes; $l$ lavas; Eu/Eu* $=\left[\mathrm{Eu}_{N} /\left(\mathrm{Sm}_{\mathrm{N}} \times \mathrm{Gd}_{\mathrm{N}}\right)^{1 / 2}\right]$, $N=$ chondrite normalized values. Chondrite data come from Sun and McDonough (1989)

\begin{tabular}{|c|c|c|c|}
\hline & & \multicolumn{2}{|c|}{ ALCAPA Mega-unit } \\
\hline Borehole & & Kékkút-4 (865 m) & Polgárdi \\
\hline Rock type (p/l) & & 1 & $\mathrm{~d}$ \\
\hline$\overline{\mathrm{SiO}_{2}}$ & & 63.87 & 71.72 \\
\hline $\mathrm{TiO}_{2}$ & & 0.66 & 0.10 \\
\hline $\mathrm{Al}_{2} \mathrm{O}_{3}$ & & 14.98 & 12.79 \\
\hline $\mathrm{Fe}_{2} \mathrm{O}_{3} \mathrm{t}$ & & 5.17 & 2.12 \\
\hline $\mathrm{MnO}$ & & 0.08 & 0.02 \\
\hline $\mathrm{MgO}$ & $\mathrm{wt} \%$ & 2.55 & 0.33 \\
\hline $\mathrm{CaO}$ & & 1.2 & 3.91 \\
\hline $\mathrm{Na}_{2} \mathrm{O}$ & & 3.79 & 0.05 \\
\hline $\mathrm{K}_{2} \mathrm{O}$ & & 2.96 & 3.73 \\
\hline $\mathrm{P}_{2} \mathrm{O}_{5}$ & & 0.17 & 0.05 \\
\hline LOI & & 4.30 & 5.20 \\
\hline sum & & 99.85 & 100.02 \\
\hline $\mathrm{Ba}$ & & 561 & 68 \\
\hline $\mathrm{Sc}$ & & 17 & 2 \\
\hline $\mathrm{Rb}$ & & 95 & 155 \\
\hline $\mathrm{Cs}$ & & 8 & 8 \\
\hline Y & & 28 & 7 \\
\hline $\mathrm{La}$ & & 31.50 & 28.90 \\
\hline $\mathrm{Ce}$ & & 64.90 & 57.30 \\
\hline $\operatorname{Pr}$ & & 7.68 & 6.75 \\
\hline $\mathrm{Nd}$ & & 29.30 & 25.10 \\
\hline $\mathrm{Sm}$ & & 6.11 & 4.93 \\
\hline $\mathrm{Eu}$ & & 0.96 & 0.77 \\
\hline $\mathrm{Gd}$ & & 5.89 & 3.10 \\
\hline $\mathrm{Tb}$ & & 0.88 & 0.32 \\
\hline Dy & ppm & 5.25 & 1.42 \\
\hline Но & & 1.02 & 0.24 \\
\hline $\mathrm{Er}$ & & 2.99 & 0.62 \\
\hline $\mathrm{Yb}$ & & 2.92 & 0.62 \\
\hline $\mathrm{Lu}$ & & 0.42 & 0.09 \\
\hline Th & & 11 & 13 \\
\hline $\mathrm{U}$ & & 4 & 3 \\
\hline $\mathrm{V}$ & & 95 & 9 \\
\hline Co & & 13 & 1 \\
\hline $\mathrm{Ni}$ & & 27 & $<20$ \\
\hline $\mathrm{Zr}$ & & 224 & 67 \\
\hline $\mathrm{Nb}$ & & 11 & 12 \\
\hline $\mathrm{Hf}$ & & 6 & 3 \\
\hline Тa & & 1 & 1 \\
\hline $\mathrm{Ga}$ & & 17 & 17 \\
\hline $\mathrm{Be}$ & & 2 & 2 \\
\hline Sn & & 3 & 4 \\
\hline $\mathrm{Sr}$ & & 151 & 16 \\
\hline W & & 95 & 2 \\
\hline $\mathrm{Tm}$ & & 0.44 & 0.09 \\
\hline$(\mathrm{La} / \mathrm{Yb})_{\mathrm{N}}$ & & 7.7 & 33.5 \\
\hline $\mathrm{Eu} / \mathrm{Eu}^{*}$ & & 0.5 & 0.6 \\
\hline
\end{tabular}

